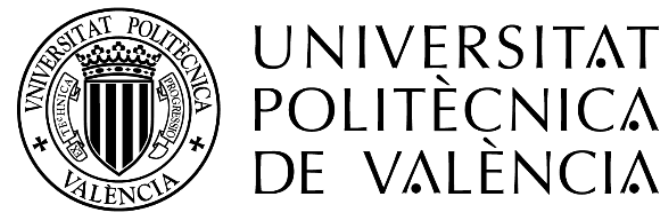

\title{
USE OF ULTRASOUND FOR THE \\ CHARACTERIZATION AND CORRECTION \\ OF TEXTURAL DEFECTS IN DRY-CURED \\ HAM
}

\section{PhD THESIS}

Submitted by:

Marina Contreras Ruiz

$\mathrm{PhD}$ Supervisors:

Dr. Jose Javier Benedito Fort

Dr. Jose Vicente García Pérez

Valencia, September 2020 

D. JOSE JAVIER BENEDITO FORT Y D. JOSE VICENTE GARCÍA PÉREZ, AMBOS CATEDRÁTICOS DE UNIVERSIDAD DEL DEPARTAMENTO DE TECNOLOGÍA DE ALIMENTOS DE LA UNIVERSITAT POLITÈCNICA DE VALÈNCIA

\section{CERTIFICAN:}

Que la memoria titulada "USE OF ULTRASOUND FOR THE CHARACTERIZATION AND CORRECTION OF TEXTURAL DEFECTS IN DRY-CURED HAM", presentada por Dña. Marina Contreras Ruiz para aspirar al grado de Doctora en Ciencia, Tecnología y Gestión Alimentaria y realizada bajo nuestra dirección en el Departamento de Tecnología de Alimentos de la Universitat Politècnica de València, cumple las condiciones adecuadas para su aceptación como Tesis Doctoral, por lo que

\section{AUTORIZAN:}

A la interesada a su presentación en el Departamento de Tecnología de Alimentos de la Universitat Politècnica de València.

Y para que conste a los efectos oportunos, presentamos la referida memoria firmando el presente certificado en Valencia a 10 de junio de 2020. 



\section{Agradecimientos}

Para empezar, diré que es el final. No es un final feliz, tan sólo es un final. Pero parece ser que ya no hay vuelta atrás. Estos versos de la canción "Miedo" son perfectos para describir el momento en el que escribo los agradecimientos de mi tesis. $Y$ es que parece ayer cuando Jose me brindó la oportunidad de comenzar esta aventura con ellos. Me acuerdo perfectamente del momento en el que me lo propuso. Luego llegó el papeleo para pedir becas y el apoyo del otro Jose. Poco después empezó todo. He tenido mucha suerte de haber caído aquí. Gracias a los dos por darme la oportunidad de hacer mi tesis doctoral con vosotros y gracias por todas las experiencias que he vivido durante este proceso. Sin duda alguna, una de las experiencias más bonitas hasta la fecha. He aprendido muchísimo y con vuestra ayuda todo ha sido más fácil. Junto a ellos, me gustaría incluir a todos los profesores del grupo ASPA, por ser un gran grupo de investigación en el que nunca faltan los almuerzos. También a todas las personas que han formado parte del laboratorio en algún momento durante estos últimos cuatro años y, sobre todo, a las componentes del Food Team, porque desde que llegaron, todo es más divertido. En especial a Lola, por enseñarme de todo un poco y por hacer que me ría tanto, y a Ángela, que ha sido mi gran amiga en toda esta aventura, compartiendo sabiduría, psicología, risas y sonrisas. De los grandes descubrimientos universitarios de esta etapa, me quedo con Martín, Rubén, Jordi, Domenico, Paolo y Vivian por todos los buenos momentos compartidos con ellos. Gracias a la Universitat Politècnica de València por concederme la beca para realizar mis estudios de doctorado, así como a los proyectos de investigación en los que he participado (RTA2013-00030C03-02 y RTA2017-00024-C04-03). También agradezco a Amparo Quiles todos los momentos que pasamos en el microscopio aprendiendo de microestructura. De mi estancia de investigación, me gustaría agradecer la ayuda recibida por Megan Povey y Melvin Holmes, fue todo un orgullo trabajar en vuestro laboratorio, y por toda la gente que conocí durante esos meses, fue una experiencia inolvidable.

Fuera del laboratorio, quiero agradecer a mi familia todo el apoyo que me ha dado siempre. A mis padres, por enseñarme, quererme y cuidarme tanto. A mi hermana, por ser única e irrepetible. A Pietro, per ascoltarmi ogni sera.

Por último, pero no menos importante, me gustaría hacer mención especial a todos los cerditos donados a la ciencia para que pudiésemos hacer e investigar jamones viscosos, pero sabrosos! 



\section{INDEX}

Abstract.

-iii-

Resumen

-vii-

Resum

-xiii-

1.INTRODUCTION $\ldots \ldots \ldots \ldots \ldots \ldots \ldots \ldots \ldots \ldots \ldots \ldots \ldots \ldots \ldots \ldots \ldots \ldots \ldots \ldots \ldots \ldots \ldots \ldots, \quad-1-$

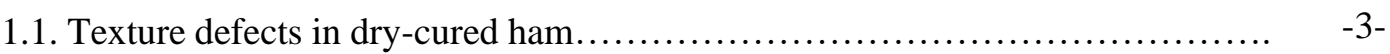

1.2. Factors affecting the development of textural defects........................

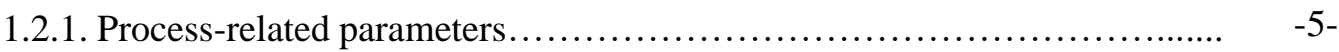

1.2.1.1. Salting ............................................................

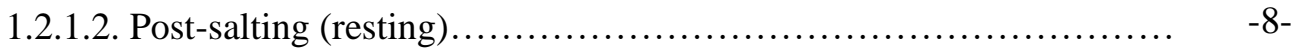

1.2.1.3. Drying-maturation............................................

1.2.2. Product-related parameters............................................

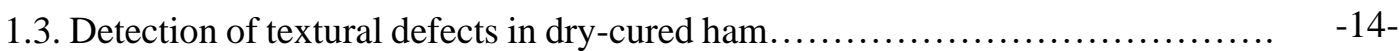

1.3.1. Non-destructive method based on electrical energy ................... $\quad-15-$

1.3.1.1. Electrical impedance spectroscopy (EIS) .....................

1.3.2. Non-destructive methods based on electromagnetic waves................ - - 16-

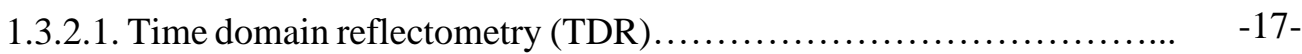

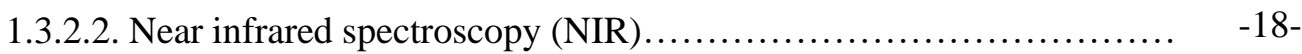

1.3.2.3. Laser-light backscattering (LBI) ...............................

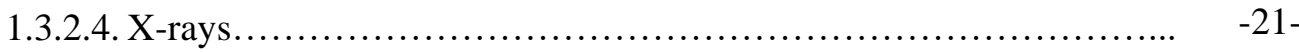

1.3.3. Non-destructive method based on mechanical waves................... $\quad-22-$

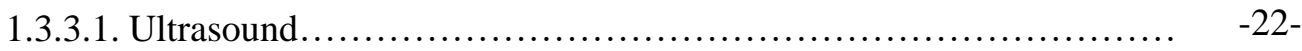

1.4. Different approaches for the correction of textural defects in dry-cured ham..... $\quad-25-$

1.4.1. Extension of the drying-maturation stage...........................

1.4.2. Application of low-temperature long-time thermal treatments at the end of manufacturing. 
1.4.3. Use of high hydrostatic pressure (HHP) .............................

1.5. Justification of the work...............................................

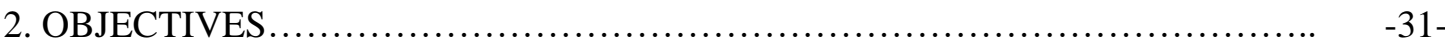

3. METHODOLOGY .................................................................

3.1. Working plan............................................................

3.2. Raw material and sample preparation.....................................

3.3. Ultrasonic analysis.....................................................

3.4. Thermal treatments.......................................................

3.4.1. Experimental set-up........................................

3.4.2. Thermal treatments modelling .......................................

3.5. Instrumental and sensory characterization...............................

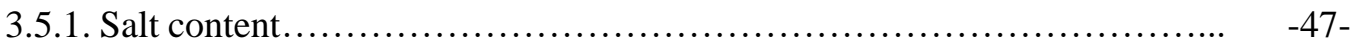

3.5.2. Moisture content..............................................

3.5.3. Proteolysis index.................................................

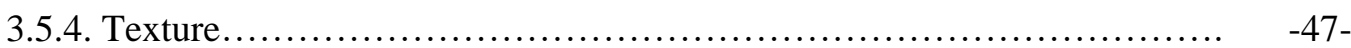

3.5.5. Microstructure analysis............................................

4. RESULTS AND DISCUSSION ................................................

4.1. Chapter 1. Dry-cured ham texture characterization.........................

"Ultrasonic monitoring of whole dry-cured hams during manufacturing as a strategy to predict the appearance of pastiness defect"...........................

"Ultrasonic characterization of composition and texture modifications in drycured pork ham during post-salting".

$-75-$

"Assessing the textural defect of pastiness in dry-cured pork ham using chemical, microstructural, textural and ultrasonic analyses".

$-97-$

"Different air-coupled ultrasonic techniques to characterize dry-cured ham texture". 
4.2. Chapter 2. Dry-cured ham texture improvement.

"Accelerated mild heating of dry-cured ham by applying power ultrasound in a liquid medium".

"Intensification of heat transfer during mild thermal treatment of dry-cured ham by using airborne ultrasound"

"Correction of defective textures in packaged dry-cured pork ham by applying conventional and ultrasonically-assisted mild thermal treatments"...

5. GENERAL DISCUSSION

6. CONCLUSIONS.

"El defecto de pastosidad y su caracterización no destructiva y no invasiva mediante ultrasonidos". 

ABSTRACT / RESUMEN / RESUM 



\title{
Use of ultrasound for the characterization and correction of textural defects in dry-cured ham
}

\begin{abstract}
Dry-cured ham is a product highly appreciated by consumers, nevertheless, there are a large number of manufacturing process-related parameters, as well as ham intrinsic factors, that compromise its final quality. One of the main problems in the quality of dry-cured ham is the appearance of textural defects, in particular, the development of pastiness. This defect is characterized by an excessive softness and loss of elastic behavior of the ham and when tasted, it provokes a feeling similar to the mouth-coating sensation produced by a flour-water paste during the mastication process. Pastiness also makes slicing difficult and promotes the adhesiveness between slices. Currently, the methods available to measure ham pastiness are time-consuming and destructive. For this reason, the seek of faster and non-destructive technologies capable of detecting pastiness is of great importance. In this sense, different technologies such as near infrared spectroscopy, X-rays or ultrasound, that have been previously tested for the nondestructive characterization of different meat products, could be of interest for the detection of ham pastiness.
\end{abstract}

Different approaches, such as the use of high hydrostatic pressure (HHP) or the application of low-temperature long-time thermal treatments (LTLT) at the end of the ham manufacturing, have been previously addressed for the correction of pastiness in dry-cured ham. Notwithstanding, the high cost and the long time required for the HHP and LTLT treatments, respectively, highlights the need for moderate cost and faster alternatives.

In this context, the main goals of this thesis were to determine the feasibility of using low intensity ultrasound to non-destructively detect the appearance of pastiness during ham manufacturing and to characterize the level of pastiness in the final product, as well as to explore the feasibility of mild ultrasonic assisted thermal treatments to correct this textural defect.

To meet the goal of ham pastiness characterization and correction, a customized drycured ham manufacturing was designed and carried out in order to obtain hams with different levels of pastiness with no remarkable differences on the salt content. During ham manufacturing, the feasibility of using contact ultrasound to monitor the appearance of pastiness was addressed. The ultrasonic velocity was measured in the raw ham, at the end of the salting and post-salting stages, 3 times during the drying-maturation and once the manufacturing was finished. At the end of the manufacturing, the pastiness level (high, medium and no pasty) was also sensory evaluated by an expert panel. As the manufacturing progressed, a progressive increase in the ultrasonic velocity, from $1536 \mathrm{~m} / \mathrm{s}$ in the raw ham to $1713 \mathrm{~m} / \mathrm{s}$ in the final dry-cured ham, was found. 
Notwithstanding, the increase in the ultrasonic velocity was not related with the pastiness defect, probably because the ham texture changes linked to pastiness were masked by the great influence of the compositional changes (salt gain and moisture loss) on the ultrasonic velocity. Therefore, the ultrasonic velocity was not an effective parameter to detect the appearance of pastiness in hams during manufacturing, neither to classify them according to its pastiness level at the end of the manufacturing.

Contact ultrasound was also used to monitor the compositional and textural changes taking place along the ham post-salting stage. For this purpose, another batch of hams was salted and post-salting times from 7 to 56 days were tested. During post-salting, the hams were weighted and the ultrasonic velocity was measured every 2 days. Each 7 post-salting days, the composition and the textural properties of a different ham were destructively analyzed. The ham weight loss during the post-salting stage was satisfactorily $(r=0.95)$ described by the increase in the ultrasonic velocity. Moreover, the salt distribution and the moisture loss in the internal parts of the ham were satisfactorily related ( $r=0.93$ and $r=0.86$, respectively) with the increase in the ultrasonic velocity. The variation in the ham hardness during post-salting was negligible and hence, the velocity increase was mainly attributed to the compositional changes, being barely affected by the changes in texture.

The hams obtained after the customized manufacturing were sliced and the ultrasonic velocity and attenuation were measured on the Biceps femoris muscle with the aim of nondestructively finding out its pastiness level. Furthermore, in order to better analyze this textural defect, the composition, protein degradation, instrumental texture and microstructure of the hams were analyzed. Pasty samples presented the highest proteolysis index (38.7\% compared to $33.1 \%$ for non-pasty hams), exhibited the more relevant structural degradation (merged myofibril structures and appearance of large gaps) and consequently, were the softest (5.4 $\mathrm{N}$ of hardness compared to $16.7 \mathrm{~N}$ for non-pasty hams) and presented the most intense viscous behavior (0.434 compared to 0.372 for non-pasty hams), although a high degree of experimental variability was found. The non-destructive assessment performed with ultrasound revealed that ultrasonic attenuation could be successfully applied for the grading of dry-cured ham slices according to its pastiness level. Thus, the greater the pastiness, the higher the ultrasonic attenuation, being the average attenuation coefficient for high, medium and no-pasty samples 48.2, 45.4 and $43.1 \mathrm{~Np} / \mathrm{m}$, respectively. Notwithstanding, the ultrasonic velocity was similar in all the ham samples, regardless its pastiness level. As observed in whole hams, the ultrasonic velocity was not a satisfactory parameter to detect pastiness in sliced ham, since the large influence of the composition on the ultrasonic velocity added to a similar salt and moisture content of the samples, regardless its pastiness level, led to a similar velocity for the different pastiness levels. 
Air-coupled ultrasonic techniques in both through-transmission and pulse-echo modes were developed for the characterization of dry-cured ham texture. The non-invasive nature of aircoupled ultrasound allows a contactless measurement, which makes easier its industrial implementation compared to conventional ultrasound techniques for high speed applications without material surface alteration and cross-contamination between food items.

As for corrective actions of the texture defects in dry-cured ham, mild thermal treatments in two different heating media (water and air) were evaluated. Furthermore, the feasibility of intensifying these mild thermal treatments with the assistance of power ultrasound was considered. For that purpose, commercial vacuum-packed dry-cured ham slices were heated in a liquid medium, with and without ultrasonic assistance, at different temperatures (40, 45 and 50 ${ }^{\circ} \mathrm{C}$ ), measuring the temperature in the Biceps femoris and in the Semimembranosus muscles. Regarding the treatments in air, commercial vacuum-packed dry-cured ham cylinders were used. In the first set of experiments, ham was heated at a constant air velocity $(2 \mathrm{~m} / \mathrm{s})$ until different temperatures $\left(40,45\right.$ and $\left.50^{\circ} \mathrm{C}\right)$ were reached. While in the second set of experiments, ham was treated at constant air temperature $\left(50^{\circ} \mathrm{C}\right)$ at different air velocities $(1,2,3,4$ and $6 \mathrm{~m} / \mathrm{s})$. In both sets, the treatments were performed with and without power ultrasound application, measuring the temperature in the center of the cylinder. Thermal treatments were extended until a target temperature of $5{ }^{\circ} \mathrm{C}$ lower than the medium (water-air) heating temperature was reached, thus, holding temperature stage did not exist and the treatments only considered the heating one. The heating kinetics of the ham treated in both water and air heating media were mathematically described by means of a heat conduction model. Once the heating finalized, the textural changes of ham (hardness and elastic behavior) were evaluated. The experiments showed that power ultrasound application sped up the heat transfer, significantly $(\mathrm{p}<0.05)$ shortening the heating time and increasing the apparent thermal diffusivity up to 51 and $37 \%$ for water and air heat treatments, respectively. For the thermal treatments using water, the increase in temperature during the heating brought about a lower ultrasonic intensification (the apparent thermal diffusivity was increased by $51 \%$ at $40{ }^{\circ} \mathrm{C}$ compared to the $21 \%$ at $50{ }^{\circ} \mathrm{C}$ ). On the contrary, in experiments with air, the higher the temperature, the greater the ultrasonic enhancement (the apparent thermal diffusivity was increased by $5 \%$ at $40{ }^{\circ} \mathrm{C}$ compared to the $38 \%$ at $50{ }^{\circ} \mathrm{C}$ ). The effect of the ultrasound application decreased as the air velocity increased, being minimal when the air velocity was the highest (the apparent thermal diffusivity was increased by $21 \%$ at $1 \mathrm{~m} / \mathrm{s}$ compared to the $5 \%$ at $6 \mathrm{~m} / \mathrm{s}$ ). As regards the changes in the textural properties of ham after the mild thermal treatments at short times, an increase in hardness and elastic behavior was observed.

Finally, the texture correction in dry-cured ham with different levels of pastiness was tackled. For this purpose, vacuum-packed dry-cured ham slices with high, medium and no pastiness were heated in a liquid medium at 40 and $50{ }^{\circ} \mathrm{C}$ for a longer time $(5 \mathrm{~h}$, including heating 
and holding stages) than heating experiments, with and without the assistance of power ultrasound during the heating phase. The texture (hardness, elastic behavior and adhesiveness) and the microstructure of the ham was evaluated in both treated and control samples. After the mild thermal treatments, the texture of ham was improved since the hardness was increased (102\%) and the viscous behavior diminished $(11 \%)$. On average, the increase of hardness at $50{ }^{\circ} \mathrm{C}$ was $159 \%$ higher than at $40{ }^{\circ} \mathrm{C}$, while the decrease of the viscous behavior was $13.5 \%$ larger at $50{ }^{\circ} \mathrm{C}$ compared to $40{ }^{\circ} \mathrm{C}$. The ham adhesiveness was also enhanced independently of the treatment temperature, with a 55\% reduction being observed. The application of power ultrasound during the heating phase did not involve any additional textural change. Likewise, after the thermal treatments, the microstructure of hams with pastiness notably changed, experiencing a severe shrinkage of the myofibrils, which contributed to explain the reported textural changes.

In conclusion, pastiness is a relevant and highly complex textural defect in dry-cured ham. The use of contact ultrasound and the measurement of the ultrasonic attenuation could be considered a potential technology to non-destructively detect and characterize pastiness in sliced dry-cured ham. Future work should focus on extending this approach to identify pasty whole hams, considering for this purpose the use of air-coupled ultrasound. Moreover, the use of mild thermal treatments in liquid or gas media could be a feasible method to correct the defective texture of dry-cured hams and the application of power ultrasound during the heating phase could be a relevant means of speeding up the thermal treatments. 


\section{Uso de ultrasonidos para la caracterización y la corrección de defectos texturales en jamón curado}

\section{Resumen}

El jamón curado es un producto muy apreciado por los consumidores, sin embargo, existen numerosos parámetros relacionados con el procesado, así como factores intrínsecos del jamón, que comprometen su calidad final. Uno de los principales problemas de calidad del jamón curado es la aparición de defectos de textura, concretamente, el desarrollo de pastosidad. Este defecto se caracteriza por una textura excesivamente blanda y un comportamiento menos elástico del jamón. A nivel sensorial, provoca una sensación de recubrimiento en boca similar a la masticación de una pasta de harina y agua. La pastosidad también dificulta el loncheado y promueve la adhesividad entre lonchas. Actualmente, los métodos disponibles para caracterizar la pastosidad requieren mucho tiempo y son destructivos. Por esta razón, la búsqueda de tecnologías más rápidas y no destructivas capaces de detectar la pastosidad es de gran importancia. En este sentido, distintas tecnologías como espectroscopía de infrarrojo cercano, rayos-X o ultrasonidos, que han sido ensayadas previamente para la caracterización no destructiva de diferentes productos cárnicos, podrían ser de interés para la detección de pastosidad en jamón.

Diferentes alternativas, como el uso de altas presiones hidrostáticas (HHP) o la aplicación de tratamientos térmicos de larga duración a baja temperatura (LTLT) al final del proceso de elaboración del jamón, han sido abordadas previamente para la corrección de pastosidad en jamón curado. Sin embargo, el elevado coste y el largo tiempo requerido para los tratamientos HHP y LTLT, respectivamente, pone de manifiesto la necesidad de encontrar alternativas con un coste moderado y más rápidas.

En este contexto, los principales objetivos de esta tesis fueron determinar la viabilidad de la utilización de ultrasonidos de baja intensidad para detectar de manera no destructiva la aparición de pastosidad durante el proceso de elaboración de jamón curado y caracterizar el nivel de pastosidad en el producto final, así como explorar la viabilidad de tratamientos térmicos moderados asistidos por ultrasonidos de alta intensidad para corregir dicho defecto de textura.

Para cumplir el objetivo de caracterizar y corregir el defecto de pastosidad en jamón, se diseñó y se llevó a cabo un proceso de elaboración para obtener jamones con distintos niveles de pastosidad sin diferencias considerables del contenido en sal. Durante el procesado, se abordó la viabilidad de utilizar ultrasonidos por contacto para monitorizar la aparición de la pastosidad. Así, la velocidad ultrasónica se midió en el jamón fresco, al final de las etapas de salado y postsalado, 3 veces durante el secado-maduración y una vez terminado el proceso de elaboración. Al final del procesado, también se evaluó el nivel de pastosidad (alto, medio y sin pastosidad) en el jamón 
loncheado por un panel experto. A medida que avanzó el proceso de elaboración, se observó un aumento progresivo de la velocidad ultrasónica, de $1536 \mathrm{~m} / \mathrm{s}$ en jamón fresco hasta $1713 \mathrm{~m} / \mathrm{s}$ en jamón curado. Sin embargo, el aumento en la velocidad ultrasónica no se relacionó con el defecto de pastosidad, probablemente porque los cambios de textura del jamón vinculados con la pastosidad fueron enmascarados por la gran influencia de los cambios composicionales (ganancia de sal y pérdida de humedad) en la velocidad ultrasónica. Así, la velocidad ultrasónica no fue un parámetro útil para detectar la aparición de pastosidad en jamón durante su procesado ni para clasificar los jamones según su nivel de pastosidad al final del procesado.

Los ultrasonidos por contacto también se utilizaron para monitorizar los cambios composicionales y texturales que tienen lugar a lo largo de la etapa de postsalado del jamón. Para ello, se saló otro lote de jamones y se evaluaron distintos tiempos de postsalado, desde 7 hasta 56 días. Durante el postsalado, los jamones se pesaron y se midió su velocidad ultrasónica cada 2 días. Cada 7 días de postsalado, se analizó destructivamente la composición y las propiedades texturales de un jamón. La pérdida de peso de los jamones durante la etapa de postsalado fue descrita satisfactoriamente $(\mathrm{r}=0.95)$ por el aumento de la velocidad ultrasónica. Además, la distribución de sal y la pérdida de humedad en el interior del jamón se relacionaron de forma satisfactoria ( $\mathrm{r}=0.93$ y r=0.86, respectivamente) con el aumento de la velocidad ultrasónica. La variación en la dureza del jamón durante el postsalado fue no significativa y, por ello, el aumento de la velocidad ultrasónica se atribuyó principalmente a los cambios de composición, siendo apenas afectada por los cambios de textura.

Los jamones obtenidos con distintos niveles de pastosidad después del proceso de elaboración, se cortaron y se midió la velocidad y la atenuación ultrasónica del músculo Biceps femoris con el objetivo de averiguar de forma no destructiva su nivel de pastosidad. Además, con el fin de analizar mejor este defecto de textura, se analizaron el índice de proteólisis, la microestructura, la textura instrumental y la composición de los jamones. Las muestras pastosas presentaron el índice de proteólisis más alto (38.7\% comparado con el $33.1 \%$ de los jamones no pastosos), mostraron la degradación estructural más relevante (estructuras miofibrilares fusionadas y aparición de grandes huecos) y, en consecuencia, fueron las más blandas (5.4 N de dureza en comparación con los $16.7 \mathrm{~N}$ de los jamones no pastosos) y presentaron el comportamiento viscoso más intenso (0.434 comparado con el 0.372 de los jamones no pastosos), aunque se encontró una gran variabilidad experimental. La evaluación no destructiva llevada a cabo mediante ultrasonidos reveló que la atenuación ultrasónica se podría aplicar con éxito para la clasificación de las lonchas de jamón curado según su nivel de pastosidad. Así, cuanto mayor fue la pastosidad, mayor fue la atenuación ultrasónica, siendo el coeficiente de atenuación promedio de las muestras con alta, media y sin pastosidad de 48.2, 45.4 y $43.1 \mathrm{~Np} / \mathrm{m}$, respectivamente. Sin embargo, la velocidad ultrasónica fue muy similar en todas las muestras de 
jamón, independientemente de su nivel de pastosidad. Como se observó en los jamones enteros, la velocidad ultrasónica no fue un parámetro útil para cuantificar el defecto de pastosidad en jamón loncheado, ya que la gran influencia de la composición en la velocidad ultrasónica sumada al contenido similar de sal y humedad de las muestras, independientemente de su nivel de pastosidad, dio lugar a una velocidad similar en todos los niveles de pastosidad.

Se desarrollaron dos técnicas de ultrasonidos acoplados por aire, tanto en modo transmisión-recepción como en pulso-eco, para caracterizar la textura de jamón curado. El carácter no invasivo de los ultrasonidos acoplados por aire permite llevar a cabo medidas sin contacto, facilitando su aplicación a nivel industrial en comparación con las técnicas ultrasónicas convencionales, ya que pueden realizarse medidas a mayor velocidad, sin alterar la superficie del material y evitando la contaminación cruzada entre alimentos.

En cuanto a las medidas de corrección de defectos texturales en jamón curado, se evaluaron tratamientos térmicos moderados en dos medios de calentamiento diferentes (agua y aire). Además, se consideró la viabilidad de intensificar dichos tratamientos mediante la aplicación de ultrasonidos de alta intensidad (o de potencia). Para ello, se calentaron lonchas de jamón curado comercial envasadas al vacío en medio líquido, con y sin la aplicación de ultrasonidos, a diferentes temperaturas $\left(40,45\right.$ y $\left.50^{\circ} \mathrm{C}\right)$, midiendo la temperatura en los músculos Biceps femoris y Semimembranosus. Respecto a los tratamientos en aire, se utilizaron cilindros de jamón curado comercial envasado al vacío. En el primer set de experimentos, el jamón se calentó a velocidad de aire constante $(2 \mathrm{~m} / \mathrm{s})$ a diferentes temperaturas $\left(40,45\right.$ y $\left.50{ }^{\circ} \mathrm{C}\right)$; mientras que, en el segundo experimento, el jamón se calentó a temperatura de aire constante $\left(50{ }^{\circ} \mathrm{C}\right)$ a distintas velocidades $(1,2,3,4$ y $6 \mathrm{~m} / \mathrm{s})$. En los dos sets, los tratamientos se llevaron a cabo con y sin la aplicación de ultrasonidos de potencia, midiendo la temperatura en el centro del cilindro. Los tratamientos térmicos se prolongaron hasta alcanzar la temperatura objetivo, definida como $5{ }^{\circ} \mathrm{C}$ por debajo de la temperatura del medio de calentamiento (agua o aire). Así, no se llevó a cabo una fase de mantenimiento de la temperatura y sólo se consideró la fase de calentamiento de los tratamientos térmicos. Las cinéticas de calentamiento del jamón tratado tanto en agua como en aire se describieron matemáticamente considerando que la transferencia de calor estuvo únicamente controlada por conducción. Una vez finalizado el calentamiento, se evaluaron los cambios texturales del jamón (dureza y comportamiento elástico). Los experimentos mostraron que la aplicación de ultrasonidos de potencia aceleró la transferencia de calor, reduciendo significativamente $(\mathrm{p}<0.05)$ el tiempo de calentamiento y aumentando la difusividad térmica aparente hasta un 51 y $37 \%$ en los tratamientos térmicos en agua y aire, respectivamente. En el caso de los tratamientos térmicos en agua, el aumento de la temperatura durante el calentamiento provocó una intensificación ultrasónica menor (la difusividad térmica aparente aumentó un 51\% a $40^{\circ} \mathrm{C}$ comparado con el $21 \%$ a $50^{\circ} \mathrm{C}$ ). Por el contrario, en las experiencias en aire, cuanto mayor 
fue la temperatura, más efectiva fue la aplicación de los ultrasonidos (la difusividad térmica aparente incrementó un $5 \%$ a $40{ }^{\circ} \mathrm{C}$ comparado con el $38 \%$ a $50{ }^{\circ} \mathrm{C}$ ). El efecto de la aplicación de los ultrasonidos disminuyó con el aumento de la velocidad del aire, siendo mínimo con la velocidad de aire más alta ensayada (la difusividad térmica aparente aumentó un $21 \%$ a $1 \mathrm{~m} / \mathrm{s}$ comparado con el $5 \%$ a $6 \mathrm{~m} / \mathrm{s}$ ). En cuanto a los cambios de las propiedades texturales del jamón después de los tratamientos térmicos moderados limitados a la fase de calentamiento, se observó un aumento en su dureza y en su comportamiento elástico.

Por último, se abordó la corrección de textura en jamón curado con distintos niveles de pastosidad. Para ello, se calentaron lonchas de jamón con alta, media y sin pastosidad envasadas al vacío en medio líquido a 40 y $50{ }^{\circ} \mathrm{C}$ durante tiempos más largos $(5 \mathrm{~h}$, incluyendo las fases de calentamiento y mantenimiento) que en las experiencias sólo de calentamiento, con y sin la aplicación de ultrasonidos de potencia únicamente durante la fase de calentamiento. La textura (dureza, comportamiento elástico y adhesividad) y la microestructura del jamón se evaluaron tanto en las muestras tratadas como en las control. Después de los tratamientos térmicos moderados, la textura del jamón se vio mejorada puesto que su dureza aumentó (102\%) y su comportamiento viscoso disminuyó (11\%). En promedio, el aumento de la dureza a $50{ }^{\circ} \mathrm{C}$ fue un $159 \%$ mayor que a $40{ }^{\circ} \mathrm{C}$, mientras que la disminución del comportamiento viscoso fue un $13.5 \%$ mayor a $50{ }^{\circ} \mathrm{C}$ que a $40{ }^{\circ} \mathrm{C}$. La adhesividad del jamón también se vio disminuida, independientemente de la temperatura de tratamiento, observándose una reducción media del 55\%. La aplicación de ultrasonidos de potencia durante la fase de calentamiento no implicó ningún cambio textural adicional. Asimismo, después de los tratamientos térmicos, la microestructura de los jamones con alta pastosidad cambió notablemente, experimentando una severa contracción de las miofibrillas, lo cual contribuyó a explicar los cambios de textura mencionados.

En conclusión, la pastosidad es un defecto textural relevante y muy complejo en jamón curado. El uso de ultrasonidos por contacto y la medida de la atenuación ultrasónica podría considerarse a nivel industrial para detectar y caracterizar de forma no destructiva la pastosidad en lonchas de jamón curado. Futuros trabajos deberían estar orientados a la aplicación de esta tecnología para la identificación de jamones pastosos enteros, considerando para ello el uso de ultrasonidos acoplados por aire. Además, el uso de tratamientos térmicos moderados en medio líquido o gaseoso podría ser un método viable para corregir la textura defectuosa de jamones curados y la aplicación de ultrasonidos de potencia durante la fase de calentamiento podría considerarse para acelerar los tratamientos térmicos. 


\section{Ús d'ultrasons per a la caracterització i la correcció de defectes texturals en pernil curat}

\section{Resum}

El pernil curat és un producte molt apreciat pels consumidors, no obstant això, existeixen nombrosos paràmetres relacionats amb el processament, així com factors intrínsecs del pernil, que comprometen la seua qualitat final. Un dels principals problemes de qualitat del pernil curat és l'aparició de defectes de textura, concretament, el desenvolupament de pastositat. Aquest defecte es caracteritza per una excessiva blanor i una pèrdua del comportament elàstic del pernil. A nivell sensorial, provoca una sensació de recobriment en boca similar a la masticació d'una pasta de farina i aigua. La pastositat també dificulta el tallat i promou l'adhesivitat entre rodanxes. Actualment, els mètodes disponibles per a mesurar la pastositat requereixen molt de temps i són destructius. Per aquesta raó, la cerca de tecnologies més ràpides i no destructives capaces de detectar la pastositat és de gran importància. En aquest sentit, diferents tecnologies com espectroscòpia d'infraroig pròxim, raigs- $X$ o ultrasons, que han sigut assajades prèviament per a la caracterització no destructiva de diferents productes carnis, podrien ser d'interés per a la detecció de pastositat en pernil.

Diferents alternatives, com l'ús d'altes pressions hidroestàtiques (HHP) o l'aplicació de tractaments tèrmics de llarga duració a baixa temperatura (LTLT) al final del procés d'elaboració del pernil, han sigut abordades prèviament per a la correcció de pastositat en pernil curat. No obstant això, l'elevat cost i el llarg temps requerit per als tractaments HHP i LTLT, respectivament, posa de manifest la necessitat de trobar alternatives amb un cost moderat i més ràpides.

En aquest context, els principals objectius d'aquesta tesi van ser determinar la viabilitat de la utilització dels ultrasons de baixa intensità per a detectar de manera no destructiva l'aparició de pastositat durant el procés d'elaboració de pernil curat i caracteritzar el nivell de pastositat en el producte final, així com explorar la viabilitat de tractaments tèrmics moderats assistits per ultrasons d'alta intensitat per a corregir aquest defecte de textura.

Per a complir l'objectiu de caracteritzar i corregir el defecte de pastositat en pernil, es va dissenyar i es va dur a terme un procés d'elaboració configurat per a obtindre pernils amb diferents nivells de pastositat sense diferències considerables del contingut en sal. Durant el processament, es va abordar la viabilitat d'utilitzar ultrasons per contacte per a monitorar l'aparició de pastositat. La velocitat ultrasònica es va mesurar en el pernil fresc, al final de les etapes de salat i postsalat, 3 vegades durant l'assecat-maduració i una vegada acabat el procés d'elaboració. Al final del processament, el nivell de pastositat (alta, mitjana i sense pastositat) també es va avaluar per un 
panell expert. A mesura que va avançar el procés d'elaboració, es va trobar un augment progressiu de la velocitat ultrasònica, anant des de $1536 \mathrm{~m} / \mathrm{s}$ en pernil fresc fins a $1713 \mathrm{~m} / \mathrm{s}$ en pernil curat. No obstant això, l'augment en la velocitat ultrasònica no es va relacionar amb el defecte de pastositat, probablement perquè els canvis de textura del pernil vinculats amb la pastositat van ser emmascarats per la gran influència dels canvis composicionals (guany de sal i pèrdua d'humitat) en la velocitat ultrasònica. Així, la velocitat ultrasònica no va ser un paràmetre efectiu per a detectar l'aparició de pastositat en pernil durant el seu processament ni per a classificar els pernils segons el seu nivell de pastositat al final del processament.

Els ultrasons per contacte també es van utilitzar per a monitorar els canvis composicionals i texturals que tenen lloc al llarg de l'etapa de postsalat del pernil. Per a això, es va salar un altre lot de pernils i es van avaluar diferents temps de postsalat, des de 7 fins a 56 dies. Durant el postsalat, els pernils es van pesar i es va mesurar la seua velocitat ultrasònica cada 2 dies. Cada 7 dies de postsalat, es van analitzar destructivament la composició i les propietats texturals d'un pernil diferent. La pèrdua de pes dels pernils durant l'etapa de postsalat va ser descrita satisfactòriament $(r=0.95)$ per l'augment de la velocitat ultrasònica. A més, la distribució de sal i la pèrdua d'humitat a l'interior del pernil es van relacionar de manera satisfactòria ( $r=0.93$ i r $r=0.86$, respectivament) amb l'augment de la velocitat ultrasònica. La variació en la duresa del pernil durant el postsalat va ser mínima i, per això, l'augment de la velocitat ultrasònica es va atribuir principalment als canvis de composició, sent a penes afectada pels canvis de textura.

Els pernils obtinguts després del procés d'elaboració configurat per a obtindre pernils amb diferents nivells de pastositat, es van tallar i es va mesurar la velocitat i l'atenuació ultrasònica del múscul Biceps femoris amb l'objectiu d'esbrinar de forma no destructiva el seu nivell de pastositat. A més, amb la finalitat d'analitzar millor aquest defecte de textura, es van analitzar la composició, la degradació proteica, la textura instrumental i la microestructura dels pernils. Les mostres pastoses van presentar l'índex de proteòlisis més alt (38.7\% comparat amb el 33.1\% dels pernils no pastosos), van mostrar la degradació estructural més rellevant (estructures miofibrilars fusionades i aparició de grans buits) i, en conseqüència, van ser les més blanes ( $5.4 \mathrm{~N}$ de duresa en comparació amb els $16.7 \mathrm{~N}$ dels pernils no pastosos) i van presentar el comportament viscós més intens ( 0.434 comparat amb el 0.372 dels pernils no pastosos), encara que es va trobar una gran variabilitat experimental. L'avaluació no destructiva duta a terme mitjançant ultrasons va revelar que l'atenuació ultrasònica es podria aplicar amb èxit per a la classificació de les rodanxes de pernil curat segons el seu nivell de pastositat. Així, com més gran va ser la pastositat, major va ser l'atenuació ultrasònica, sent el coeficient d'atenuació mitjà de les mostres amb alta, mitjana i sense pastositat 48.2, 45.4 i $43.1 \mathrm{~Np} / \mathrm{m}$, respectivament. No obstant això, la velocitat ultrasònica va ser molt similar en totes les mostres de pernil, independentment del seu nivell de pastositat. Com es va observar en els pernils sencers, la velocitat ultrasònica no va ser un paràmetre 
satisfactori per a detectar el defecte de pastositat en pernil tallat a rodanxes, ja que la gran influència de la composició en la velocitat ultrasònica sumada al contingut similar de sal i humitat de les mostres, independentment del seu nivell de pastositat, va donar lloc a una velocitat similar en tots els nivells de pastositat.

Es van desenvolupar dues tècniques d'ultrasons acoblats per aire, tant en manera transmissió-recepció com en pols-eco, per a caracteritzar la textura de pernil curat. El caràcter no invasiu dels ultrasons acoblats per aire permet dur a terme mesures sense contacte, facilitant la seua aplicació a nivell industrial en comparació amb les tècniques ultrasòniques convencionals, ja que poden realitzar-se mesures a major velocitat, sense alterar la superfície del material i evitant la contaminació creuada entre aliments.

Quant a les mesures de correcció de defectes texturals en pernil curat, es van avaluar tractaments tèrmics moderats en dos medis de calfament diferents (aigua i aire). A més, es va considerar la viabilitat d'intensificar aquests tractaments mitjançant l'aplicació d'ultrasons de potència. Per a això, es van calfar rodanxes de pernil curat comercial envasades al buit en medi líquid, amb i sense l'aplicació d'ultrasons, a diferents temperatures $\left(40,45\right.$ i $\left.50{ }^{\circ} \mathrm{C}\right)$, mesurant la temperatura en els músculs Biceps femoris i Semimembranosus. Respecte als tractaments en aire, es van utilitzar cilindres de pernil curat comercial envasat al buit. En el primer set d'experiments, el pernil es va calfar a velocitat d'aire constant $(2 \mathrm{~m} / \mathrm{s})$ fins que es van aconseguir diferents temperatures $\left(40,45 \mathrm{i} 50{ }^{\circ} \mathrm{C}\right)$. Mentre que, en el segon, el pernil es va calfar a temperatura d'aire constant $\left(50^{\circ} \mathrm{C}\right)$ a diferents velocitats $(1,2,3,4$ i $6 \mathrm{~m} / \mathrm{s})$. En els dos sets, els tractaments es van dur a terme amb i sense l'aplicació d'ultrasons de potència, mesurant la temperatura en el centre del cilindre. Els tractaments tèrmics es van prolongar fins a aconseguir la temperatura objectiu, definida $5{ }^{\circ} \mathrm{C}$ per davall de la temperatura del medi de calfament (aigua o aire); així, no es va dur a terme una fase de manteniment de la temperatura i només es va considerar la fase de calfament dels tractaments tèrmics. Les cinètiques de calfament del pernil tractat tant en aigua com en aire es van descriure matemàticament mitjançant un model de conducció de calor. Una vegada finalitzat el calfament, es van avaluar els canvis texturals del pernil (duresa i comportament elàstic). Els experiments van mostrar que l'aplicació d'ultrasons de potència va accelerar la transferència de calor, reduint significativament $(\mathrm{p}<0.05)$ el temps de calfament $\mathrm{i}$ augmentant la difusivitat tèrmica aparent fins a un 51 i $37 \%$ en els tractaments tèrmics en aigua i aire, respectivament. En el cas dels tractaments tèrmics en aigua, l'augment de la temperatura durant el calfament va provocar una intensificació ultrasònica menor (la difusivitat tèrmica aparent va augmentar un $51 \%$ a $40{ }^{\circ} \mathrm{C}$ comparat amb el $21 \%$ a $50{ }^{\circ} \mathrm{C}$ ). Per contra, en les experiències en aire, com més alta va ser la temperatura, més efectiva va ser l'aplicació dels ultrasons (la difusivitat tèrmica aparent va incrementar un $5 \%$ a $40{ }^{\circ} \mathrm{C}$ comparat amb el $38 \%$ a $50{ }^{\circ} \mathrm{C}$ ). L'efecte de l'aplicació dels ultrasons va disminuir amb l'augment de la velocitat de l'aire, sent mínim amb la 
velocitat d'aire més alta assajada (la difusivitat tèrmica aparent va augmentar un $21 \%$ a $1 \mathrm{~m} / \mathrm{s}$ comparat amb el $5 \%$ a $6 \mathrm{~m} / \mathrm{s}$ ). Quant als canvis de les propietats texturals del pernil després dels tractaments tèrmics moderats a temps curts, es va observar un augment en la seua duresa i en el seu comportament elàstic.

Finalment, es va abordar la correcció de textura en pernil curat amb diferents nivells de pastositat. Per a això, es van calfar rodanxes de pernil amb alta, mitjana i sense pastositat envasades al buit en medi líquid a 40 i $50{ }^{\circ} \mathrm{C}$ durant temps més llargs $(5 \mathrm{~h}$, incloent les fases de calfament i manteniment) que en les experiències només de calfament, amb i sense l'aplicació d'ultrasons de potència durant la fase de calfament. La textura (duresa, comportament elàstic i adhesivitat) i la microestructura del pernil es van avaluar tant en les mostres tractades com en les control. Després dels tractaments tèrmics moderats, la textura del pernil es va veure millorada perquè la seua duresa va augmentar (102\%) i el seu comportament viscós va disminuir (11\%). En mitjana, l'augment de la duresa a $50{ }^{\circ} \mathrm{C}$ va ser un $159 \%$ major que a $40{ }^{\circ} \mathrm{C}$, mentre que la disminució del comportament viscós va ser un $13.5 \%$ major a $50{ }^{\circ} \mathrm{C}$ que a $40{ }^{\circ} \mathrm{C}$. L'adhesivitat del pernil també es va veure disminuïda, independentment de la temperatura de tractament, observant-se una reducció del 55\%. L'aplicació d'ultrasons de potència durant la fase de calfament no va implicar cap canvi textural addicional. Així mateix, després dels tractaments tèrmics, la microestructura dels pernils amb alta pastositat va canviar notablement, experimentant una severa contracció de les miofibrilles, el que va contribuir a explicar els canvis de textura esmentats.

En conclusió, la pastositat és un defecte de textura rellevant i molt complex en pernil curat. L'ús d'ultrasons per contacte i la mesura de l'atenuació ultrasònica podria considerar-se una tecnologia potencial per a detectar i caracteritzar de forma no destructiva la pastositat en rodanxes de pernil curat. Futurs treballs haurien d'estar orientats a l'aplicació d'aquesta tecnologia per a la identificació de pernils pastosos sencers, considerant per a això l'ús d'ultrasons acoblats per aire. A més, l'ús de tractaments tèrmics moderats en medi líquid o gasós podria ser un mètode viable per a corregir la textura defectuosa de pernils curats i l'aplicació d'ultrasons de potència durant la fase de calfament podria ser una forma rellevant d'accelerar els tractaments tèrmics. 




\section{INTRODUCTION}





\subsection{Texture defects in dry-cured ham}

Spain is the world's leading producer of dry-cured ham (Jiménez-Colmenero et al., 2010), which is considered a traditional product with high economical relevance. The manufacturing of dry-cured ham is a long and complex process. Every step of the process, from the green ham piece selection to the final stages of drying-maturation, is relevant to achieve high quality standards. Quality of dry-cured ham is complex to be defined, since it depends on three main attributes: color, flavor and texture. Every property has an important contribution to the overall quality of the ham, but specifically, texture is one of the main sensory attributes appreciated in dry-cured ham (Font-i-furnols \& Guerrero, 2014).

Bourne (2002) claimed that texture consists of different physical sensations, being preferable to talk about "textural properties", which concerns a group of related properties, rather than "texture", which infers to a single parameter. Thus, he suggested that "the textural properties of a food are that group of physical characteristics that arise from the structural elements of the food, are sensed by the feeling of touch, are related to the deformation, disintegration and flow of the food under a force, and are measured objectively by functions of mass, time and distance". Thus, texture is a multi-parameter sensory attribute (Szczesniak, 2002), related to the structure of the meat and which involves several senses in its determination (Kragten \& Gil, 2015). In this regard, the appearance of a defective texture in dry-cured ham, largely detracts its quality and could negatively influence on consumer's perception and acceptability (Fulladosa et al., 2018), even causing rejection by consumers (Morales et al., 2008, 2013).

During dry-cured ham manufacturing, the product undergoes chemical and physical changes that contribute to their final textural properties (Fulladosa et al., 2018). Different textural defects can appear during the processing, among them, softness, crustiness, adhesiveness and pastiness. Firstly, softness in dry-cured ham is described as softy texture in the mouth (Resano et al., 2010) and it appears mainly when there is a high moisture content in the sample. Secondly, crustiness, also known as case-hardening, is defined as the excessively hardening of the surface of the ham and it usually takes place during dehydration stages, when the water flow from the inside of the ham is slower compared to the water evaporation from the surface. Thirdly, adhesiveness in dry-cured ham is described as sticky to teeth and mouth (Resano et al., 2010) and it is related to an excessive protein breakdown. Lastly, pastiness involves a lack of elastic behavior and the appearance of more intense viscous behavior, which is reflected in an unusual softness, oily touch and intense adhesiveness in some cases (Parolari et al., 1994). Regarding the sensory perception when tasting pasty dry-cured ham, it is described as a feeling similar to the mouthcoating sensation produced by a flour-water paste during the mastication process. Besides, hams with this textural defect also have other unwanted properties such as a somewhat bitter, piquant 
flavor and a lack of the typical aroma of dry-cured ham (García-Rey et al., 2005). Pastiness defect in dry-cured ham has been related to an excessive protein breakdown occurring during the elaboration process and in some cases, pastiness has also been related with a high moisture content. Additionally, hams exhibiting pasty texture are much more prone to exhibit a linked defect since they can develop tyrosine crystals or white film discoloration more easily (Parolari, 1996). Summarizing, dry-cured hams with softy texture have been mainly linked to excessively high moisture-content samples, while pastiness seems to be characterized not only by a high water content but also to a high protein breakdown and other physicochemical changes. Therefore, pastiness defect is considered a very complex phenomenon (García-Rey et al., 2004).

In general terms, dry-cured ham texture is jointly controlled by the intrinsic characteristics of the raw ham and by a series of technological parameters linked to the elaboration process (Guerrero et al., 1999) (Figure 1). In the following section, the elaboration of dry-cured ham will be described as well as the technological parameters (process-related parameters) and the raw ham intrinsic characteristics (product-related parameters) affecting the appearance of defective textures, specifically pastiness.

\section{DRY-CURED HAM TEXTURE IS DETERMINED BY}
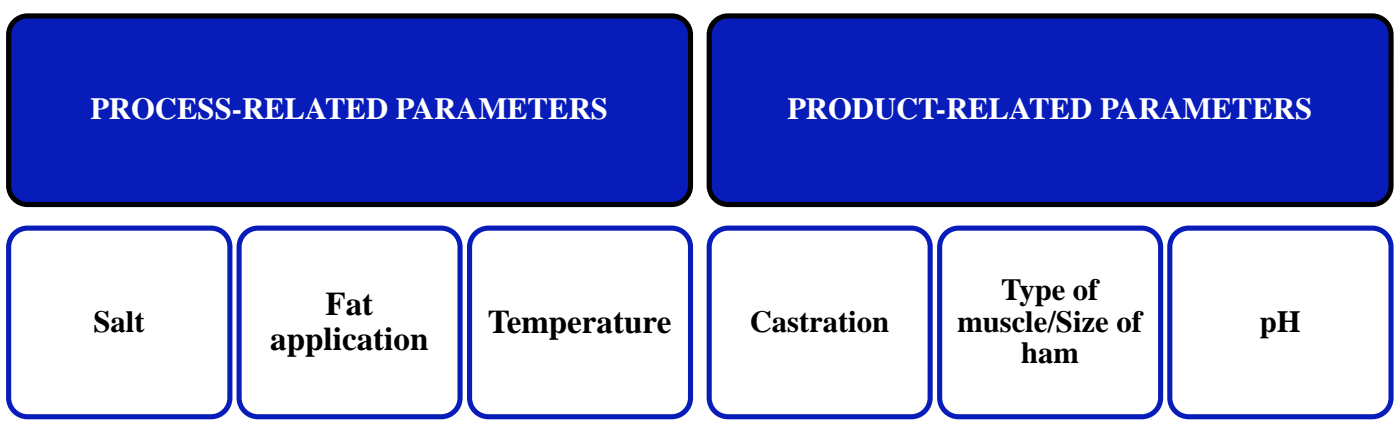

Figure 1. Factors affecting the development of textural defects in dry-cured ham. 


\subsection{Factors affecting the development of textural defects}

\subsubsection{Process-related parameters}

The elaboration process of dry-cured ham may vary slightly depending on the production area around the Spanish region, but basically, it is divided in four main stages (Figure 2).

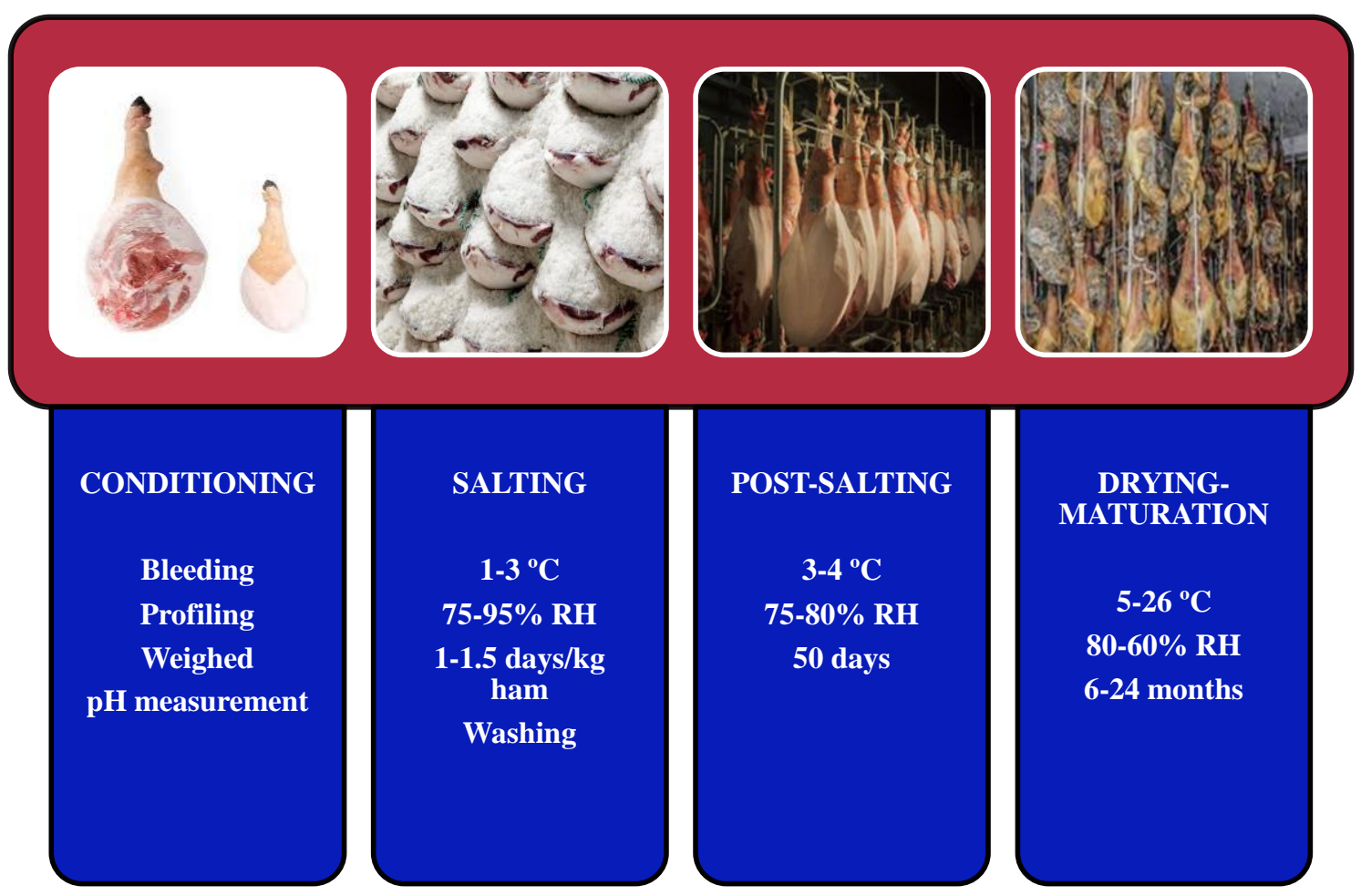

Figure 2. Stages of dry-cured ham manufacturing.

The raw ham is subjected to a simple preparation and conditioning (Figure 2) before the manufacturing starts itself. Firstly, raw hams are bled and subsequently profiled. Normally in Spain, hams are V-shaped profiled. Thus, the rind and a part of the backfat can be used for other purposes and at the same time, the thickness of the subcutaneous fat is standardized. Furthermore, the profiling helps the contraction of the muscle during drying (Arnau \& Gou, 2001) and the slicing at the end of the manufacturing. Green ham $\mathrm{pH}$ is also measured. It is advisable to avoid a pH higher than 6.2 for microbial safety reasons (Newton \& Gill, 1981) as well as to avoid soft texture problems (Arnau, 1993). Hams are also weighted to estimate the manufacturing time. Finally, hams are classified according to its $\mathrm{pH}$, weight, age and animal breed before the manufacturing. 


\subsubsection{Salting}

\section{What is it?}

The first stage of dry-cured ham manufacturing is the salting. Normally in Spain, hams are dry-salted, frequently named "pile salting", which means that hams are stacked with a layer of curing agents between them forming a pile under temperature and relative humidity (RH) controlled conditions. Curing agents includes common salt $(\mathrm{NaCl})$ and nitrifying salts (nitrates and nitrites). Thus, curing agents are solubilized in the native water present in the ham surface and penetrate by diffusion.

\section{Objective}

The main aim of the salting stage is the uptake of curing agents into the ham. Two opposite mass transport processes occur during salting: a water flow from the inside of the ham to the outside and diffusion of the curing agents into the ham, which during this stage mainly penetrate in the outer part of the ham, close to its surface (Figure 3). Regarding the specific function of every curing agent, common salt has a key role in the ham manufacturing. On the one hand, salt is responsible of reducing the water activity of the ham and contributes to its preservation during the subsequent stages of the process. On the other hand, salt induces a characteristic protein denaturation that contributes to the release of peptides and free amino acids that participate in the formation of aromatic compounds that contribute to the development of the typical sensory characteristics of dry-cured ham (Ventanas et al., 1992). In addition, salt is by far the most effective mean to control excessive proteolysis (Arnau et al., 1998) that could lead to defective textures. Nitrates and nitrites are responsible of the typical color of the ham and contribute to control the growth of microorganisms.

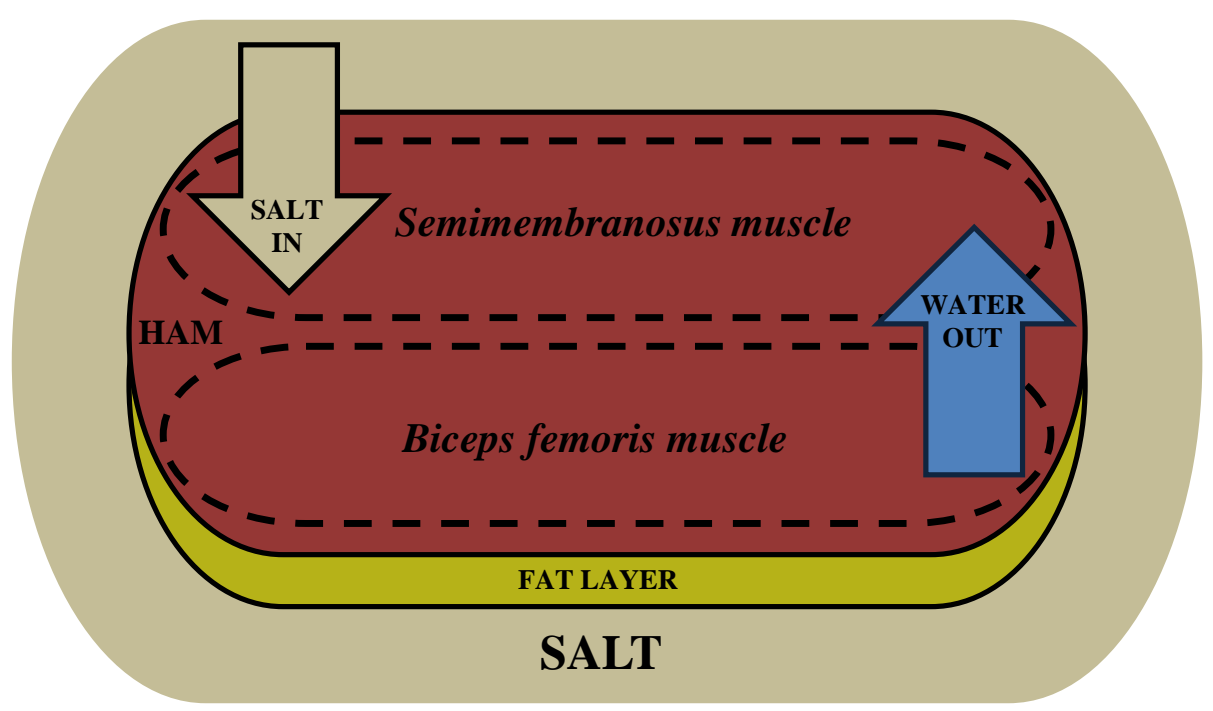

Figure 3. Diagram of mass transfer during ham salting. 


\section{Process conditions}

Salting is carried out under refrigerated conditions $\left(1-3{ }^{\circ} \mathrm{C}\right)$ to avoid microbial growth (Pérez-Alvarez et al., 1997) and at high relative humidity (75-95\%) to facilitate salt solubilization around the ham surface, contributing to a better diffusion of the curing agents into the ham.

\section{Length}

In the industry, the length of the salting stage is decided depending on the weight of the ham and usually it takes around 1-1.5 days per kg. However, it is difficult to control the amount of salt uptake by each ham due to several factors. In this regard, the non-homogeneous environmental conditions in the salting chamber, the number of piles and the different position of the ham in the salting layers, the heterogeneous formation of brine between the ham surface and the dry salt and the size of the salt crystals can influence the salt uptake (Albarracín et al., 2011; Barat et al., 2004).

Currently, new trends are looking for the reduction of salt in processed meat products, since they constitute one of the major sources of $\mathrm{NaCl}$ in the diet (Desmond, 2006). Specifically, in Spain, dry-cured ham is the second highest source of sodium in the diet after bread (Ministerio de Sanidad y Consumo de España, 2012). However, in dry-cured ham, the salt is a fundamental ingredient since it has been proved to have an important role in the development of ham flavor and also an inhibitory effect on the microbial growth and on the excessive activity of proteases (Toldrá et al., 1997). The proteases are a group of enzymes tasked to breakdown protein bonds that are associated to the appearance of pastiness defect (Andrés et al., 2004).

\section{Influence of salting on texture and pastiness defect}

Many studies have been carried out with the aim of reducing the salting time or the amount of salt during dry-cured ham manufacturing. In this regard and focusing first on the reduction of the salting time, Martín et al. (1998) studied the evolution of two batches of ham salted 1 or 1.5 days per $\mathrm{kg}$ of ham. At the end of the elaboration process, hams salted for a longer time had a greater salt concentration and a lower non-protein nitrogen content (NPN) compared to hams salted for 1 day. NPN is the free nitrogen promoted by proteolysis activity. However, the effect of salt concentration on the protein breakdown was limited since differences of NPN in both batches were not significant ( $p>0.05$ ). The uncontrolled protein cleavage provoked by the reduction of salt can cause a loss of skeletal properties of muscle bundles, giving rise to abnormal softness (Parolari, 1996). Thus, the excessive formation of NPN during ham processing has been related to the appearance of softy textures and concretely to pastiness (García-Garrido et al., 2000). In another study, Arnau et al. (1997) tested three different salting times. As a standard salting time, 1 day per $\mathrm{kg}$ of ham was established, and the standard salting time plus two extra 
days and minus two days were also considered. Dry-cured ham texture was sensory evaluated in Biceps femoris muscle at the end of the elaboration process by an expert panel. Thus, Arnau et al. (1997) reported that by extending 2 days the salting time, the final hardness increased by $21 \%$. However, pastiness was similar in every ham, regardless of the salting time used.

As for the reduction of salt during ham manufacturing, Arnau et al. (1998) studied how the salt concentration affected the sensory characteristics of dry-cured hams. Samples were grouped into two batches, depending on the amount of salt used: 55 and $80 \mathrm{~g}$ of $\mathrm{NaCl}$ per $\mathrm{kg}$ of ham. Hams were tested at the end of the elaboration process by an expert panel, finding out that hams salted with more salt were less pasty and adhesive than samples salted with a lower amount of salt. Ruiz-Ramírez et al. (2006a) also studied the final texture of hams salted with different amounts of salt but by using instrumental methods. Thus, salt amounts of $20,50 \mathrm{or} 80 \mathrm{~g}$ per $\mathrm{kg}$ of ham were used and at the end of the drying-maturation period, ham texture was evaluated by Texture Profile Analysis (TPA). The amount of salt used during the salting period affected the proteolysis index (PI), which is an index relating the NPN to the total nitrogen of the sample. Consequently, samples cured with a high level of salt showed a lower proteolysis index and were more prone to present harder texture, compared to samples salted with less salt. In this sense, Ruiz-Ramírez et al. (2005) separated and individually salted the Semimembranosus (SM) and Biceps femoris (BF) muscles with a mixture of curing agents and different amounts of salt: 20, 50 and $80 \mathrm{~g}$ per kg of muscle. Subsequently, the muscles were dried in a tunnel drier. The authors reported that the higher the salt content in dry-cured ham muscles, the higher the hardness.

One of the reasons of the hardness decrease when reducing the salting time or the amount of salt used during salting has been attributed to a less compaction of the myofibrillar structure, compared to the compaction provoked when a high salt content is reached (Shomer et al., 1987). As for the reasons of the pastiness development in hams with a low amount of salt, it has been identified the low inhibition of the proteolytic enzymes (Geesink \& Koohmaraie, 1999; Toldrá \& Etherington, 1988), since the stabilizing effect that the salt has on proteases is insufficient when salt is diminished.

\subsubsection{Post-salting (resting)}

After salting, the excess of surface salt is removed by washing or using compressed air. Subsequently, the post-salting or resting stage starts. 
What is it?

During post-salting, hams are hung in cages inside a temperature and relative humidity controlled chamber.

\section{Objective}

During salting, the curing agents mainly get stuck on the surface of the ham, penetrating only into the outermost ham layers. Therefore, the aim of the post-salting stage is the diffusion of the curing agents towards the inner part of the ham and its homogeneous distribution into the whole ham. Furthermore, an important amount of water is also lost during the post-salting, since the water activity of the ham is still higher than the relative humidity of the post-salting chamber. Thus, both the homogeneous distribution of the curing agents and the water loss, jointly contribute to assure the optimum development of the following stages (Barat et al., 2004).

\section{Process conditions}

The temperature of the chamber during the post-salting stage is still low $\left(3-4{ }^{\circ} \mathrm{C}\right)$ because of the risk of microbial growth and the relative humidity is in the range $75-80 \%$ to contribute to the water loss.

\section{Length}

The average length of the post-salting stage is established at around 50 days although it is variable depending on the size and on the amount of inter and intramuscular fat of the ham.

\section{Influence of post-salting on texture and pastiness defect}

The post-salting is the stage where the protein breakdown starts. A high proteolytic activity can lead to the development of pastiness (Ruiz-Ramírez et al., 2006b). For this reason, the post-salting is a critical stage in order to avoid pastiness appearance. One of the factors influencing the activity of the proteolytic enzymes during the post-salting is the temperature used, since the activity of the enzymes is closely related to this parameter (García-Garrido et al., 2000). Thus, the higher the temperature, the larger the protease activity, until the maximum optimum temperature (around $45^{\circ} \mathrm{C}$ at $\mathrm{pH}$ 6) is reached. Since the post-salting is a long stage that affects the industry productivity, it is interesting to shorten it by increasing the temperature. However, this action may induce a greater proteolytic activity that can lead to textural problems, such as pastiness. Despite the great relevance of post-salting on the onset of pastiness defect, there is no literature relating the influence of the post-salting stage on the appearance of textural problems in dry-cured ham. 


\subsubsection{Drying-maturation}

\section{What is it?}

In the last stage of the process, hams are placed in natural or air-forced drying chambers. Each piece is hung conveniently separated from each other to improve airflow around it and thus, the mass transfer convection rate.

\section{Objective}

The drying-maturation stage seeks to achieve different aims. Firstly, the final salt diffusion and distribution through the ham takes place. Besides that, the dehydration continues progressively (to prevent surface slime or crustiness) during the drying-maturation in order to reduce the water activity of the ham. As the stage progresses, the characteristic dry-cured ham flavor is developed since lipolysis and most of the proteolytic reactions take place in this stage.

\section{Process conditions}

The temperature during drying-maturation is increased gradually from 5 to $26^{\circ} \mathrm{C}$ while the relative humidity is decreased from 80 to $60 \%$, in order to facilitate a progressive dehydration while microbial growth is controlled throughout the whole ham piece by the combined effect of temperature and water activity.

\section{Length}

The length of the drying-maturation depends on the type of ham but the typical range for white pig ham is established from 7 to 12 months, while for Iberian ham, the length ranges between 14 to 36 months.

\section{Influence of drying-maturation on texture and pastiness defect}

Some technological parameters during drying-maturation affecting the development of textural defects will be described as follows.

\section{Fat application}

Normally, the ham is rubbed with a layer of fat at the beginning of the drying-maturation stage in order to avoid the growing of mites. However, the premature or excessive application of fat may result in a high degree of moisture retention and consequently, it could provoke the development of an unusual softness on the surface (Parolari, 1996). 


\section{Temperature}

Temperature is one of the key factors in ham manufacturing. This processing parameter can have an important impact on the productivity of hams since higher temperatures drive to shorten the manufacturing time. However, in turn, high processing temperatures can also significantly influence a series of ham quality characteristics. Thus, an excessive high temperature could involve a surface water evaporation faster than the internal water diffusion, provoking the development of crustiness (excessive dried surface) that hinders the subsequent drying. Likewise, the enhancement of the proteolytic activity of enzymes with the increase of temperature can also influence the development of defective textures. Focusing on the evolution of dry-cured ham texture during drying-maturation at different temperatures, several studies have been previously addressed. In this regard, Virgili et al. (1995) compared the use of two different drying temperatures $\left(15\right.$ and $18{ }^{\circ} \mathrm{C}$ ) during one month. The authors found out that the higher the temperature, the higher the amount of NPN. Thus, NPN was higher in hams held at $18^{\circ} \mathrm{C}$ than in their counterparts at $15^{\circ} \mathrm{C}$. These results agreed the ones found by Rico et al. (1991), that reported an increase in the proteolytic activity of the enzyme cathepsin B at high temperatures, in the range from 15 to $25^{\circ} \mathrm{C}$, causing a massive breakdown of proteins recorded as an increase of NPN. As for sensory aspects, because of the abnormal protein cleavage, defective mushy mouthfeel was developed. Similarly, Martín et al. (1998) manufactured two batches of dry-cured ham, \#1 following a traditional process where the post-salting and the drying-maturation were carried out following the temperature of the year seasons (starting in wintertime) and \#2 following a modern system where all the process stages were developed in controlled conditions of temperature and relative humidity. The higher NPN amount observed in hams elaborated with the traditional procedure was consistent with a higher temperature $\left(\Delta \mathrm{T}=5 \pm 2{ }^{\circ} \mathrm{C}\right)$ registered during the process compared to the controlled system. Especially at the end of the drying-maturation period, the temperature steeply increased, which induced the increment of NPN. Arnau et al. (1997) evaluated the use of three different temperatures $\left(20,25\right.$ and $\left.30^{\circ} \mathrm{C}\right)$ during the last month of a 6month drying-maturation period of dry-cured ham with the aim of accelerating the dryingmaturation. The final texture at the end of the processing was evaluated on BF muscle by an expert panel. The modification of the temperature had an important effect on the texture of the hams since the ones aged at the highest temperature $\left(30^{\circ} \mathrm{C}\right)$ presented the greatest pastiness and were the softest, which was related to the increase of protease activity at high temperatures (Rico et al., 1990). More recently, Gou et al. (2008), during the last 10 days of the drying-maturation, kept a batch of hams at $18{ }^{\circ} \mathrm{C}$ and another one at $30{ }^{\circ} \mathrm{C}$, maintaining in both cases the same relative humidity (40-55\%). It was found that the PI was higher in hams aged at $30^{\circ} \mathrm{C}$ compared to the ones aged at $18^{\circ} \mathrm{C}$. This result agrees with previous studies (Zhao et al., 2005) which showed that high temperatures promoted the activity of cathepsins B and L, increasing the PI. Similarly, 
Morales et al. (2007b) found that the storage of the hams for the last 30 days of ageing at $30^{\circ} \mathrm{C}$, provoked a significantly higher PI than at $5{ }^{\circ} \mathrm{C}$. As a conclusion from the studies found in the literature relating the temperature used during the drying-maturation of dry-cured ham with the appearance of texture defects, it is shown the difficulty of regulating the temperature to avoid an excessive proteolysis during dry-cured ham manufacturing.

\subsubsection{Product-related parameters}

In addition to the process-related parameters, raw ham intrinsic parameters could also influence the development of textural defects during manufacturing. For this reason, an initial classification of the raw hams according to their characteristics could contribute to facilitate the subsequent manufacturing. Some of the ham intrinsic parameters affecting the development of textural defects are described as follows.

\section{Castration}

The castration of the pig has been presented as an important factor influencing the final texture of dry-cured ham. Thus, Bañón et al. (2003) studied the influence of the castration of male pigs on the quality of dry-cured ham. They found out that hams from castrated pigs were significantly $(\mathrm{p}<0.05)$ softer than those from non-castrated ones. Nevertheless, and as a general conclusion, it was shown that hams from castrated males were more appropriate for dry-cured ham manufacturing, since the castration improved quality characteristics, not only texture but also flavor.

\section{Type of muscle}

The type of muscle is also an intrinsic parameter that can influence the development of defective textures. Depending on the position of the muscle inside the ham, it can be more prone to present textural defects. As previously mentioned, during salting, hams are covered with a mixture of curing agents, mainly common salt, nitrates and nitrites. The skin and subcutaneous fat protect one of the sides of the ham and prevent, almost completely, the penetration of the curing agents during salting. Thereby, salt is mainly concentrated in the opposite surface to the skin, where SM muscle is located. This implies that the salt, which prevents the proteolysis, reaches the muscles located deeper and closer to the subcutaneous fat, specially the BF, only by diffusion during the post-salting period. Furthermore, the subcutaneous fat and the skin also slow down the water loss (Figure 3). Thus, a low salt and high water content in BF muscle should contribute to greater proteolysis, which could lead to higher pastiness and lower hardness 
compared to an outer muscle like SM (Arnau et al., 1997). In this sense, García-Rey et al. (2006) also postulated that pastiness mainly occurs in BF muscle.

As an example of different textural properties in dry-cured ham depending on the muscle type, Bermúdez et al. (2014) examined the effect of muscle type on the physicochemical and sensory characteristics of dry-cured Celta ham at the end of the manufacturing. Thus, the shear force, that represents the maximum cutting resistance, was significantly higher $(\mathrm{p}<0.001)$ in SM muscle compared to BF muscle. Furthermore, the expert panel scored samples from SM muscle as harder $(\mathrm{p}<0.001)$ than those from BF muscle. Overall, as previously mentioned, the moisture content in SM is lower than BF, which also contributes to explain why SM becomes harder than $\mathrm{BF}$.

Size

The size of the ham may also influence on pastiness incidence. In heavy and large hams, the diffusion path for salt and water transport is longer. Thus, it takes longer both the salt to reach inside the ham and the water to come out to the ham surface. Because of a non-homogeneous salt distribution and a slow water loss, heavy hams are more prone to be softer, especially the inside muscles such as BF (Parolari, 1996).

$p H$

$\mathrm{pH}$ is also one of the most important intrinsic parameters of dry-cured ham that can affect the pastiness onset. Different studies have addressed the impact of a $\mathrm{pH}$ out of the normal range (5.7-6.2) in the development of pastiness. In this context, Arnau et al. (1998) investigated the texture of hams with high $(\mathrm{pH}>6.2)$ and low $\mathrm{pH}(\mathrm{pH}<5.8)$. At the end of the manufacturing, a sensory texture analysis was carried out in BF muscle by an expert panel and hardness, pastiness and adhesiveness were evaluated. Hams with high $\mathrm{pH}$ were softer, pastier and more adhesive than hams with low pH. Similarly, Guerrero et al. (1999) evaluated sensory and instrumentally the texture of dry-cured ham with low $\left(\mathrm{pH}_{24}<5.8\right)$ and high $\mathrm{pH}\left(\mathrm{pH}_{24}>6.2\right)$ measured at $24 \mathrm{~h}$ postmortem in SM muscle. At the end of the elaboration process, the expert sensory panel found out that high $\mathrm{pH}$ hams presented a lower hardness and a higher pastiness and adhesiveness than the low pH hams. In line with the sensory results, the instrumental texture tests (puncture and compression tests) also showed that high $\mathrm{pH}$ hams were softer. In the same study, Guerrero et al. (1999) also analyzed the evolution of texture during the manufacturing process of dry-cured ham with low and high $\mathrm{pH}$. A modified TPA and a uniaxial compression test were carried out in whole hams on the surface of SM muscle in three different moments of the manufacturing: at the end of the post-salting stage (45 days), at the beginning (60 days) and in the middle of the dry-maturation stage (120 days). Both textural measurement tests showed statistically significant $(\mathrm{p}<0.05)$ 
differences depending on the $\mathrm{pH}$, being hams with high $\mathrm{pH}$ softer at the three sampling times. The same procedure was carried out by Ruiz-Ramírez et al. (2006a), who measured ham pH at $24 \mathrm{~h}$ post mortem in SM muscle and divided the samples into hams with low $\left(\mathrm{pH}_{24}<5.7\right)$ and high $\mathrm{pH}$ $\left(\mathrm{pH}_{24}>6.2\right)$ in order to study the final texture of hams depending on the initial $\mathrm{pH}$. These authors found that there were not significant $(\mathrm{p}>0.05)$ differences between $\mathrm{pH}$ groups, however, hams with high $\mathrm{pH}$ tended to be, on average, harder than those with low $\mathrm{pH}$. This result was contrary to those found in the previous studies (Arnau et al., 1998; Guerrero et al., 1999) and it was attributed to the fact that low $\mathrm{pH}$ favors the proteolytic activity of the cathepsin enzymes throughout the manufacturing (Parreño et al., 1994).

Ruiz-Ramírez et al. (2005) also selected green hams with two levels of pH measured in $\mathrm{SM}$ muscle at $24 \mathrm{~h}$ postmortem: high $\left(\mathrm{pH}_{24}>6.2\right)$ and low $\mathrm{pH}\left(\mathrm{pH}_{24}<5.7\right)$. Unlike the previous cases where a standard manufacturing was carried out, in this study, SM and BF muscles were removed from the hams, rubbed with curing salt, vacuum-packed during a curing period of 45 days and dried in a drying tunnel until reaching different levels of water content. The authors found that samples from hams with high $\mathrm{pH}$ were slightly softer than those with low $\mathrm{pH}$, when the water content was between 0.6 to $1.3\left(\mathrm{~kg} \mathrm{H}_{2} \mathrm{O} / \mathrm{kg}\right.$ dry matter), but for lower water contents, hardness was similar in both $\mathrm{pH}$ groups. Low $\mathrm{pH}$ group involves that the $\mathrm{pH}$ is close to the isoelectric point of myosin, thus, more intermolecular links between negatively and positively charged groups take place, which could result in harder samples (Hamm, 1986). Additionally, high $\mathrm{pH}$ group encourages the activity of calpain enzymes that are active during several weeks and could decrease hardness.

Considering the existing literature, it could be concluded that a ham $\mathrm{pH}$ out of a standard range (5.7-6.2) could negatively influence the texture of the final dry-cured ham.

\subsection{Detection of textural defects in dry-cured ham}

As previously mentioned, many factors can influence the development of textural defects in dry-cured ham. Thus, it would be of great relevance to have tools able to detect the appearance of defective textures during the manufacturing and actuate on the process conditions in order to slow-down or avoid the progress and development of these defective textures. In addition, once the manufacturing process is completed, it would be also relevant to detect the defective hams before expedition for commercialization and thus, to avoid introducing low quality hams into the market. Moreover, the possibility of correcting the defective textures of hams identified as pasty is of great interest. 
The quality of dry-cured ham is traditionally assessed by chemical, sensory or textural analyses, which are tedious, time-consuming, need specialized technicians and destroy the product (Ávila et al., 2019). For this reason, it could be advantageous to seek faster methods and mostly, non-destructive methods that could shed light on the sensory attributes with the ultimate goal of implementing them for online applications. In this regard, new technologies have been tested in the literature that could be used to evaluate, in a non-destructive and faster way, ham properties. Specifically, three types of non-destructive technologies that have been used to detect defective textures in dry-cured ham will be described in detail in the following sections. Firstly, a technology based on electrical impedance will be tackled. Secondly, different technologies based on electromagnetic waves will be described. Thirdly, a technology based on mechanical waves, which has been used in this thesis to address the characterization of dry-cured ham texture, will be explained.

\subsubsection{Non-destructive method based on electrical energy}

\subsubsection{Electrical impedance spectroscopy (EIS)}

What is and how does it work?

Electrical impedance spectroscopy (EIS) is an analytical technology that applies an electrical current or voltage at different frequencies to a sample and detects the response of the sample as electrical impedance (Macdonald, 1992). EIS has been widely used as a standard characterization technology for many materials.

\section{Which parameters can be measured?}

Among others, the electrical parameters that can be obtained with an EIS device are the electrical impedance modulus at low $\left(\mathrm{R}_{0}\right)$ and high frequencies $\left(\mathrm{R}_{\mathrm{inf}}\right)$, the ratio between the aforementioned parameters $\left(\mathrm{R}_{\mathrm{inf}} / \mathrm{R}_{0}\right)$ and the characteristic frequency of the region under measurement $\left(\mathrm{F}_{\mathrm{c}}\right)$.

\section{Advantages of the technology}

Some of the main advantages of this technology are the quick and low-cost character of the equipment.

\section{Uses of the technology}

Guerrero et al. (2004) used a prototype of an EIS device to evaluate its feasibility to predict the final texture of dry-cured hams depending on the quality of the green hams. EIS 
measurements were carried out at $36 \mathrm{~h}$ post mortem in BF and SM muscles while the final sensory properties in both muscles of dry-cured ham, like hardness, pastiness or adhesiveness, were measured at the end of manufacturing by means of an expert panel. In BF muscle, the electrical parameters did not correlate with the sensory analyses, indicating that EIS measurements were not able to differentiate between dry-cured ham groups classified according to their pastiness level. By contrast, regarding SM muscle, the electrical impedance modulus at low frequencies $\left(\mathrm{R}_{0}\right), \mathrm{R}_{\mathrm{inf}} / \mathrm{R}_{0}$ ratio and the characteristic frequency $\left(\mathrm{F}_{\mathrm{c}}\right)$ were significantly $(\mathrm{p}<0.05)$ correlated with pastiness. Thus, the EIS prototype was capable to correctly classify up to $69.2 \%$ of the hams depending on its pastiness level (high, medium and low). Therefore, the probability of the development of pastiness in dry-cured ham could be anticipated by measuring the electrical parameters of EIS in green hams.

\section{Drawbacks of the technology}

As a drawback, it has to be pointed out the invasive character of this technology since the electrodes used for taking the measurement have to be placed inside the ham.

\subsubsection{Non-destructive methods based on electromagnetic waves}

Figure 4 shows the electromagnetic spectrum with the different kinds of electromagnetic waves depending on the frequency. Inside the box, the electromagnetic technologies found in the literature for dry-cured ham characterization are depicted.

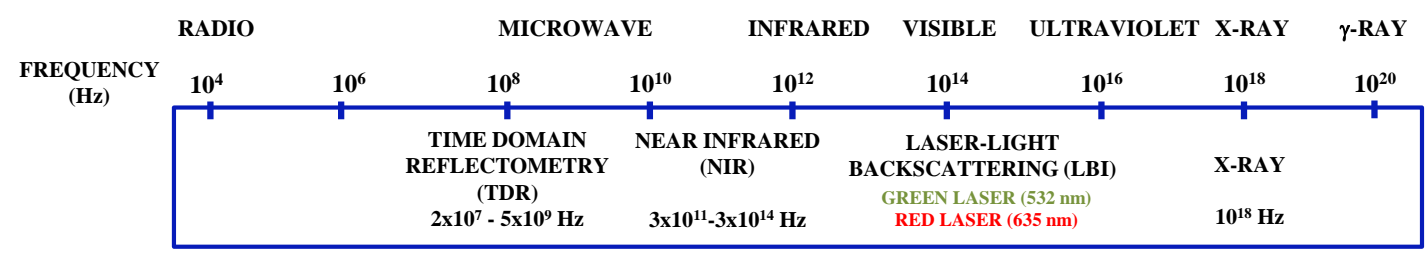

Figure 4. Electromagnetic spectrum. Inside the box, the electromagnetic technologies used for drycured ham characterization. 


\subsubsection{Time domain reflectometry (TDR)}

What is and how does it work?

Time domain reflectometry (TDR) is a technology that uses electromagnetic waves in the frequency range of the microwaves (from $2 \times 10^{7}$ to approximately $5 \times 10^{9} \mathrm{~Hz}$ ). The base of TDR consists in launching an electromagnetic pulse containing a wide range of frequencies to the material and analyzing their reflections: a change in the rotation of the polar molecules is produced and dielectric parameters can be measured.

\section{Which parameters can be measured?}

A TDR device provides a curve defined as the response resulting from the interaction between the sample and the electromagnetic pulse, relating time with the normalized reflected TDR signal. The shape of the reflected waves can be related to the properties of the food. Generally, most of the information is contained in the slope and in the plateau of the curve. Figure 5, extracted from Fulladosa et al. (2013), shows the normalized reflected TDR signal versus time obtained from samples of dry-cured ham with different ranges of water content. The slope and the plateau of the different curves can be observed.

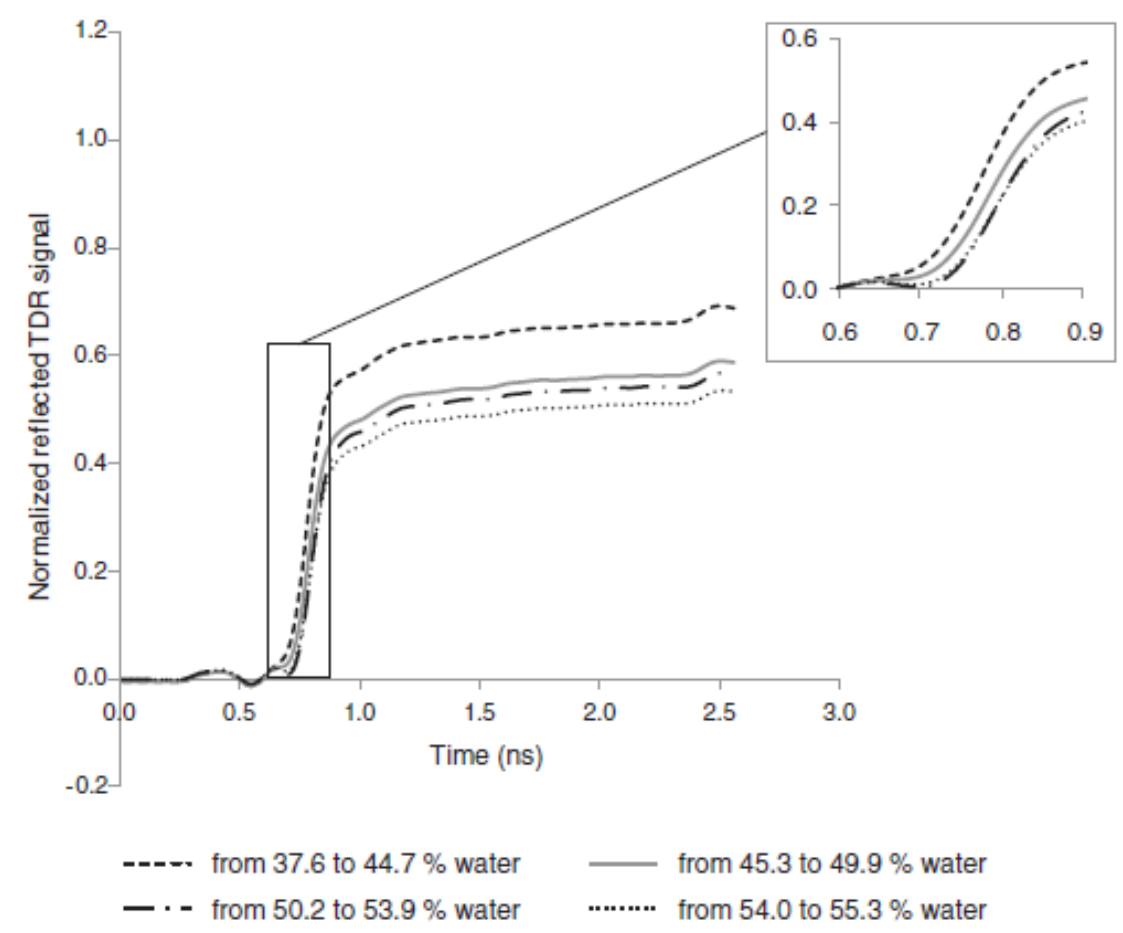

Figure 5. Reflected TDR signals of four groups of dry-cured ham samples with different ranges of water contents (Fulladosa et al., 2013). 


\section{Advantages of the technology}

The TDR equipment is small, portable and easy to handle. Besides, this technology is suitable for food control because the signal acquisition and analysis are fast enough to be implemented online.

\section{Uses of the technology}

Rubio et al. (2013) assessed the feasibility of TDR to classify dry-cured ham slices according to their pastiness level. Pastiness was induced in commercial dry-cured ham slices through the addition of a protease enzyme that acted from 0.5 to 24 hours in order to obtain different levels of pastiness: absence, moderate and intense. Subsequently, pastiness was assessed by sensory analysis and TDR. The estimation of pastiness intensity from the slope or the plateau obtained from the TDR curves was not possible. Nevertheless, a discriminant analysis performed on the TDR curves, considering all the data points, enabled to classify dry-cured ham slices in the three different levels of pastiness established with a success probability of $93 \%$.

\section{Drawbacks of the technology}

As one of the main drawbacks of TDR is that in the microwave frequency, the dielectric properties of the food products are closely related to their composition (Bohigas et al., 2008; Bohigas \& Tejada, 2009; Fulladosa et al., 2013) which could mask the relationship between the dielectric properties and the texture of the product. Furthermore, TDR is an invasive technology since the measurements are taken with a sensor that is in close contact with the sample.

\subsubsection{Near infrared spectroscopy (NIR)}

\section{What is and how does it work?}

Infrared waves are electromagnetic waves with a frequency between $3 \times 10^{11}$ and $3 \times 10^{14}$ Hz. NIR is a spectroscopy technology that employs electromagnetic radiation that interacts with the organic molecules, specifically the bonds between molecules, which absorb the energy of a specific wavelength, depending on the characteristics of their structure (Font-i-furnols et al., 2015).

\section{Which parameters can be measured?}

When NIR is applied, the energy absorption spectra at different wavelengths is registered. 


\section{Advantages of the technology}

Some of the advantages of NIR are its rapidness, accurateness and robustness. Besides, NIR can be used online. All these characteristics make this technology an effective tool for meat quality assessment (Monin, 1998).

\section{Uses of the technology}

NIR spectroscopy has been used to evaluate sensory characteristics of meat. As an example, it has been used for texture characterization of beef (Liu et al., 2003; Rødbotten et al., 2001; Venel et al., 2001). Regarding dry-cured ham, García-Rey et al. (2005) investigated the feasibility of NIR spectroscopy to grade dry-cured ham slices depending on their texture. The measurements of the NIR spectroscopy were done with a fiber optic probe in order to facilitate its use in the meat industry as a routine quality control. Likewise, the sensory properties of drycured ham were evaluated by two expert judges and scored on a scale from 1 to 10 . The results showed that pasty samples had a higher NIR absorbance than normal samples. Furthermore, two classification models, $\mathrm{K}$ nearest neighbor $(\mathrm{KNN})$ and partial least square regression (PLSR) were used to classify dry-cured ham into defective and non-defective classes, obtaining an $88.5 \%$ and $94.2 \%$ of samples correctly-classified, respectively. García-Rey et al. (2005) also proposed that NIR could be applied in raw ham in order to anticipate the development of defective textures.

\section{Drawbacks of the technology}

Notwithstanding, NIR spectroscopy has some drawbacks since the initial investment needed for the acquisition of the equipment is high. Secondly, the equipment requires a complex calibration. Thirdly, the equipment has an invasive character since the sample has to be in contact with a fiber optic probe in order to take the measurement. Finally, the penetration ability of NIR is limited and allows only a superficial analysis of the sample, hindering its use for the analysis of pastiness developed in internal muscles of whole hams.

\subsubsection{Laser-light backscattering (LBI)}

\section{What is and how does it work?}

Laser-light backscattering (LBI) is a technology based on the interaction of a light beam (electromagnetic wave with different wavelength depending on the color: $635 \mathrm{~nm}$ red laser and $532 \mathrm{~nm}$ green laser) with a material. Depending on the sample characteristics, the photons projected onto the surface of the sample are reflected, absorbed, transmitted or scattered. The physical properties of the tissue such as density, cells size or components' distribution in the 
cellular matrix and, altogether, the sample microstructure, influence the light scattering. Thus, the scattered light is presented as a proper parameter to analyze structural changes in food.

\section{Which parameters can be measured?}

From the images obtained, diverse parameters can be measured. The scattering area is one of the main LBI parameters used and is calculated segmenting the illuminated area and counting its number of pixels. Besides, average light intensity of the scattering area (pixels values) along with the light profile (shape of the curve) provide also important information.

\section{Advantages of the technology}

Among the major advantages, LBI is a non-invasive and inexpensive technology apart from being versatile and simple.

\section{Uses of the technology}

This technology could be useful to monitor processes that cause changes in the microstructure of food. Specifically, during dry-cured ham processing, LBI could be used to grade and sort the product online in the food industry depending on its texture traits. Fulladosa et al. (2017) utilized LBI to study the evolution of proteolysis induced by a proteolytic enzyme in drycured ham slices. Images were acquired during different times after the addition of the enzyme. The images showed that the scattering areas as well as the light profiles were really similar over the progress of the proteolysis. By contrast, average light intensity of the scattering area was decreased with the enzyme action, following a non-linear relationship. This fact was linked to the breakage of the protein matrix that provoked more intramuscular spaces and less robust cell membranes and therefore the average light intensity was lower.

\section{Drawbacks of the technology}

Notwithstanding, LBI presents a number of drawbacks since the response to the light beam incidence can be modified due to diverse factors. Firstly, modifications in the moisture content or in the proteolysis index provoke similar changes in light scattering and hence estimating whether the changes are due to a modification in dry-cured ham composition or to texture alterations becomes difficult. Secondly, dry-cured ham surface properties as the onset of tyrosine precipitates and intramuscular fat flecks could provoke changes on the light scattering. Thirdly, color changes in the ham could also influence the backscattering of light patterns. Moreover, the penetration capacity of this technology is also limited. 


\subsubsection{X-rays}

\section{What is and how does it work?}

$\mathrm{X}$-rays are electromagnetic waves with a frequency around $10^{18} \mathrm{~Hz}$. X-ray technology is based on the different X-ray attenuation of waves traveling through a sample, depending on the tissue density, which permits the quantification or differentiation of tissues of different density.

\section{Which parameters can be measured?}

The energy of the transmitted X-rays is measured and the attenuation of the energy spectrum is analyzed.

\section{Advantages of the technology}

The non-invasive character and the online application are two of its main advantages.

\section{Uses of the technology}

Fulladosa et al. (2018) studied the feasibility of using X-ray multi energy spectrometry to characterize the texture of dry-cured sliced ham. For that purpose, a proteolytic enzyme was spread on the slices surface in order to force the proteolysis. Sample scans were carried out at different times to evaluate the differences on proteolysis index and thereby, on pastiness intensities. They observed that as the proteolysis intensity increased, the X-ray attenuation spectrum decreased. This fact was linked to the severe degradation of the tissue which probably led to a density decrease. In the same study (Fulladosa et al., 2018), the capacity of this technology to classify commercial dry-cured ham according to its proteolysis index, which is highly related to the defective texture level of the samples, was also evaluated. The discrimination ability of Xray multi energy was not high since only $41 \%$ of the samples were correctly classified according to their proteolysis indexes. The authors affirmed that probably one of the reasons of this result was the lower proteolysis index of commercial hams, compared to the higher index found in the samples where the proteolysis was induced by an exogenous proteolytic enzyme.

\section{Drawbacks of the technology}

One of the main drawbacks of X-ray spectrometry is the calibration of the equipment for every component, textural parameter and meat matrix to be analyzed. Generally, X-ray equipment require a high initial investment and also high safety measurements to avoid operator's health risks. Regarding the detection of textural defects, attenuation is affected by both composition and texture, being difficult to differentiate the effect of each factor. Thus, fat, salt and water content in dry-cured ham may affect the mean attenuation spectra. Accordingly, de Prados et al. (2015a) 
used an X-ray absorptiometry equipment to predict the fat content in green pork hams and determined that an increase in the fat content involved a decrease in the X-ray attenuation.

\subsubsection{Non-destructive method based on mechanical waves}

\subsubsection{Ultrasound}

\section{What is and how does it work?}

Ultrasound is a mechanical wave with frequencies that exceed the limit of human hearing (>20 kHz). Unlike technologies based on electromagnetic energy, ultrasound needs a solid, liquid or gaseous medium to propagate through it. Ultrasound can be divided into two groups depending on its frequency and intensity. Low frequency (from 20 to $100 \mathrm{kHz}$ ) or high intensity (from 10 to $1000 \mathrm{~W} / \mathrm{cm}^{2}$ ) ultrasound is used to improve a process or a product while high frequency (from $100 \mathrm{kHz}$ to $1 \mathrm{MHz})$ or low intensity $\left(<1 \mathrm{~W} / \mathrm{cm}^{2}\right)$ ultrasound is used for characterization purposes. Basically, an ultrasound system needs a pulser/receiver that generates the electrical signal that is converted into vibration by the transducer. In high intensity ultrasound, the vibration is transmitted to the medium to enhance a process. However, in low intensity ultrasound, the vibration travels through the product to be assessed and the received signal is filtered and amplified in the pulser/receiver. Subsequently, the time-domain signal is digitalized and analyzed. Within the low intensity ultrasound, two different measurement methods can be carried out: contact and air-coupled (non-contact) ultrasound, depending on whether the transducers touch or not the material to be tested, respectively.

\section{Which parameters can be measured?}

In low-intensity ultrasound, different parameters of the ultrasonic signal can be modified depending on the physicochemical properties of the medium where the ultrasonic wave is propagated. Thus, diverse ultrasonic parameters can be measured; two of the most important will be described hereunder.

The ultrasonic velocity $(V)$ is the velocity of the wave when passing through a material. It depends on the physical properties of the medium, particularly on the elastic or Young modulus (E) and on the density ( $\rho$ ) (Eq. 1) (Mulet et al., 1999), which in turn, depends on the structure and composition.

$$
V=\sqrt{\frac{E}{\rho}}
$$


Ultrasonic velocity can also be described as the quotient between the traveled distance (sample thickness, $h$ ) and the time employed (time of flight, TOF) for the wave to pass through the material (Eq. 2) (Toozandehjani et al., 2015).

$$
V=\frac{h}{T O F}
$$

Generally, ultrasonic waves used are multi-frequency in nature. Therefore, from the energy of their different frequencies, many ultrasonic parameters can be extracted. The attenuation of an ultrasonic wave is defined as the loss of energy of the wave (amplitude of the wave) when passing through a medium, regarding the traveled distance (Eq. 3):

$$
\alpha=\frac{1}{h} \ln \left(\frac{A_{0}}{A_{1}}\right)
$$

where $\alpha$ is the attenuation coefficient, $A_{0} / A_{1}$ is the amplitude ratio between the initial signal amplitude $\left(A_{0}\right)$ and the signal amplitude of the wave travelling through the sample $\left(A_{1}\right)$, and $h$ is the traveled distance (sample thickness). Attenuation, in viscoelastic materials, is related to elastic and viscous loss and scattering phenomena. As for the ultrasonic velocity, the ultrasonic attenuation provides information about the physical properties of the medium. However, the ultrasonic attenuation in solids is not a parameter easy to be measured. Firstly, solids dampen the ultrasonic signal considerably and it can become undetectable for large samples. Secondly, it is difficult to compute the energy loss on the contact interface between the sample and the transducer, which affects the accuracy of both $A_{0}$ and $A_{l}$ measurements.

\section{Advantages of the technology}

As regards the advantages of the low intensity ultrasound technology, and as previously stated, ultrasound has a high penetration capacity and therefore, it enables to cross the entire sample, studying its interior, compared to other technologies where only the surface is scanned, such as the laser-light backscattering technology. The equipment needed is cost-effective, not requiring a high initial investment, and the operation costs are reduced, since sample preparation is fast and simple. The equipment can be portable and it is relatively easy to implement in the industry in order to online monitor industrial processes. Furthermore, ultrasound is not dangerous to health and the equipment and the operators' manipulation turn out to be simpler, compared to other non-destructive technologies based on electromagnetic energy such as X-Rays, since ultrasound does not comprise any ionizing radiation.

An additional advantage of the ultrasound technology is the use of air-coupled transducers for taking the measurement. Thus, when non-contact transducers are used, the sample is not in 
touch with the equipment and hence, the ultrasonic measurement becomes absolutely noninvasive. Moreover, the non-invasive character of the air-coupled ultrasound makes ultrasound suitable for inspecting consecutively many samples without risk of cross-contamination at high speed. This feature makes the technology very attractive compared to other technologies such as NIR or TDR, where the sample has to be in contact with the probe, with the potential risk of contamination between samples.

\section{Uses of the technology}

Regarding the use of low intensity ultrasound in dry-cured ham, diverse studies can be found in the literature to characterize the amount of salt, water (de Prados et al., 2015b; de Prados et al., 2017) and fat content (de Prados et al., 2015a) but only one reference has been found addressing the textural characterization of ham using ultrasound. Thus, Corona et al. (2013a) estimated by ultrasound the changes of the texture suffered by vacuum-packed dry-cured ham slices after cold storage $\left(6^{\circ} \mathrm{C} / 120\right.$ days $)$ or after a high pressure treatment $(600 \mathrm{MPa} / 6 \mathrm{~min})$. Both, the cold storage and the high pressure treatment led to an increase in hardness that was positively correlated to the increase of ultrasonic velocity. Considering the previous literature, it can be concluded that the relationship between dry-cured ham composition and ultrasound has been deeply studied, finding out that ultrasonic parameters were closely related with the salt, moisture and fat content of ham. However, only a first approach tackling the characterization of dry-cured ham texture using ultrasound has been carried out.

\section{Drawbacks of the technology}

In respect to the drawbacks of the low intensity ultrasound technology, the dimensions of the transducers have to be considered since the information obtained from the inspected samples is restricted to the area covered by the transducer. In this sense, it is required the use of multiple measurements in order to cover the whole surface of a product, especially if the dimensions of the product are large. Besides, ultrasonic parameters are temperature dependent, which implies that temperature has to be controlled when taking the measurements. In addition, the penetration ability of ultrasound waves is reduced in the presence of air, compared to other technologies such as X-Rays. Likewise, the presence of gas in the product to be measured, as happens in a porous vegetable like eggplant, can significantly hinder the propagation of the ultrasonic wave. Sometimes, in contact ultrasound, a coupling material (water, oil) between the transducer and the sample is needed to avoid the presence of air and to ensure a correct propagation of the wave energy into the product, thus becoming an invasive technology. 


\subsection{Different approaches for the correction of textural defects in dry-cured ham}

Due to the high relevance of texture in dry-cured ham, specifically the textural defect of pastiness, different approaches have been explored to address its correction. The different approaches can be grouped in three large categories that will be addressed hereunder.

\subsubsection{Extension of the drying-maturation stage}

Diverse studies have reported that extending the drying-maturation stage at the end of the ham processing and adjusting the temperature and relative humidity could contribute to a reduction in the intensity of some textural defects. Thus, Cilla et al. (2005) reported that protracting ham maturation time to 20 months $\left(18^{\circ} \mathrm{C}, 75 \% \mathrm{RH}\right)$ increased hardness and decreased adhesiveness, measured instrumentally in SM and BF muscle, although the changes were less remarkable in BF muscle. Regarding the sensory parameters, sensory hardness had a similar evolution to the instrumental hardness, increasing until the twentieth month of maturation. In a later study, Gou et al. (2008) confirmed that including a final maturation stage at $30^{\circ} \mathrm{C}$ and low relative humidity (40-45\%) during the last 10 days of ham manufacturing, the soft texture of ham was minimized without affecting the product flavor. Thus, ham softness decreased and elasticity increased by increasing the maturation temperature from 18 to $30^{\circ} \mathrm{C}$ during the last 10 days of drying-maturation. Probably, the higher temperature of maturation $\left(30^{\circ} \mathrm{C}\right)$ promoted a more intense dehydration of the ham compared to the maturation at $18{ }^{\circ} \mathrm{C}$ and the greater loss of water could have led to a harder ham. However, the texture enhancement (lower softness and higher elasticity) was only observed in hams with a $\mathrm{pH}$ of 5.9. A negligible effect of the treatment was observed in hams with a $\mathrm{pH}$ below 5.7, which evidences the great complexity of the ham manufacturing with cross-effects between operational and ham intrinsic parameters, which must be considered in order to obtain a ham with an appropriate texture.

\subsubsection{Application of low-temperature long-time thermal treatments at the end of the manufacturing}

The second approach of pastiness correction found in the literature was the application of low-temperature long-time thermal treatments at the end of the manufacturing. In this context, Morales et al. (2008) tested a low temperature thermal treatment $\left(30^{\circ} \mathrm{C}, 7\right.$ days) at the end of the manufacturing of commercial dry-cured hams. The treatment was applied to slabs $(4 \mathrm{~cm}$ thick) and dices ( $20 \times 20 \times 15 \mathrm{~mm}$ ) of dry-cured ham vacuum-packed in bags. In both dry-cured ham formats, the treatment involved a decrease in softness (instrumentally evaluated), pastiness and 
adhesiveness (sensory tested) in BF muscle, without increasing the hardness in SM muscle or affecting their physicochemical parameters (moisture, $\mathrm{a}_{\mathrm{w}}$ and proteolysis index).

Notwithstanding, the main drawback of both approaches (the extension of the dryingmaturation stage as well as the application of low-temperature long-time thermal treatments at the end of the manufacturing) is the long time used to correct the texture, especially for industrial purposes, where time is a relevant factor to consider.

\subsubsection{Use of high hydrostatic pressure (HHP)}

The use of high hydrostatic pressure (HHP) for correcting textural defects in dry-cured ham has been addressed in the literature by different authors. In addition to the textural correction, HHP can be used to achieve the microbial safety by inactivating pathogenic microorganisms and thus, extending the shelf-life of the hams. These two roles of HHP make this technology especially relevant in the ham industry. The most recent studies addressing the use of HHP to correct textural defects in dry-cured ham will be described subsequently.

Coll-Brasas et al. (2019) observed that HHP treatment (600 MPa) produced changes on the texture of dry-cured ham with different levels of pastiness: high (sensory pastiness >2), medium (sensory pastiness between 0.5 and 2 ) and non-pasty hams (sensory pastiness <0.5). In general terms, after the HHP treatment they observed an increase in hardness (instrumentally measured), but it was more pronounced in non-pasty hams maybe because the effect of pressure is more severe in the proteins not affected by proteolysis since they still have the native structure. After the HHP treatment, a decrease in pastiness (sensory measured) was also perceived by an expert panel in high and medium pasty samples. The HHP treatments (600 MPa) were carried out at different temperatures $\left(7,20\right.$ and $\left.35^{\circ} \mathrm{C}\right)$ however, the authors estimated that when the treatment was performed, the temperature of the sample rose until 23,36 and $53{ }^{\circ} \mathrm{C}$, respectively. All the textural changes suffered by the dry-cured ham after the HHP treatment were more pronounced when the tested temperature was higher. Thus, the higher the processing temperature, the higher the hardness increase and the greater the pastiness decrease. In this sense, and considering that the treatments were always performed at the same pressure but at different temperatures, the textural changes suffered by dry-cured ham may be mainly due to the temperature rise rather than of the pressure treatment. Garcia-Gil et al. (2014) treated dry-cured hams with softness defect with $\mathrm{HHP}$ at $500 \mathrm{MPa}$. After the treatment, the texture of hams was instrumentally measured and the hams were harder and presented a more elastic behavior. From the ham microstructure, the authors also observed a higher degree of myofibrils compaction after the HHP treatment. In addition, Fulladosa et al. (2009 \& 2012) tried to obtain salt-reduced restructured dry-cured ham 
with no sensory defects by applying HHP at the end of the elaboration process. After applying an HHP treatment at $600 \mathrm{MPa}$, restructured dry-cured hams were sensory evaluated and it was perceived that hardness increased and pastiness and adhesiveness were reduced, which was mainly attributed to the aggregation of myosin molecules due to the high pressure (Yamamoto et al., 1994). However, the implementation of HHP at industrial level is constrained by its high cost, compared to other more affordable alternatives, such as the extension of the drying-maturation stage or the application of low-temperature long-time thermal treatments at the end of the manufacturing.

\subsection{Justification of the work}

Dry-cured ham is a product highly appreciated by consumers. In addition, it has a great economic interest for the food industry because of its high added value. Many factors can influence the final quality of dry-cured ham and in particular its final texture. Among the technological parameters that can influence ham texture during manufacturing, salt should be pointed out. Dry-cured ham provides one of the highest amounts of salt into the diet. Due to consumers' concerns, since an excessive sodium intake has been linked to cardiovascular diseases, ham manufacturers are trying to reduce the final salt content of the ham. However, reducing the final amount of salt in dry-cured ham can affect ham texture, since salt blocks out the activity of some proteolytic enzymes and failing to do so could provoke an uncontrolled protein breakdown during manufacturing. Consequently, hams might develop pastiness defect that affects adversely ham sliceability, promotes stickiness between slices and a mouth-coating sensation when eaten. In general, the appearance of pastiness provokes a quality loss of dry-cured ham and hence, rejection by the consumer that is translated into a loss of sales for the industry.

There exists industrial interest in detecting and characterizing properly the textural defect of pastiness. Current technologies are only based on sensory evaluations or instrumental tests, which are both destructive and time-consuming and for this reason only a limited number of samples may be evaluated. Therefore, non-destructive and faster technologies have been tested for ham texture evaluation. However, most of them are based on electromagnetic waves, which, in some cases, provide a low penetration capacity, such as NIR, and for other technologies as XRays, involve the use of ionizing radiation and a health risk for the operators. By contrast, technologies based on mechanical waves, such as ultrasound, are a promising, with high penetration capacity and non-ionizing alternative with a high potential to assess the composition and texture of a wide variety of foods. Ultrasound has been used previously to characterize drycured hams since the ultrasonic parameters vary depending on the composition and the structure of the ham. Thus, the evaluation of textural changes in dry-cured ham slices after a cold storage 
or after a high hydrostatic pressure treatment was successfully performed with ultrasound. In this sense, ultrasound could be a feasible technology to detect and characterize ham defective textures in a fast and non-destructive way. If ham pastiness could be detected during manufacturing, the technological parameters could be tuned to avoid or minimize pastiness development. On the other hand, if pastiness could be detected at the end of the manufacturing, hams could be treated for correcting the texture defect or separated for special uses (pizza toppings, ground ham...), avoiding in any case introducing dry-cured ham with textural defects into the market.

Different types of treatments have been previously assessed on dry-cured ham in order to correct defective texture and try to recover the product quality. Three different approaches have already been tested: extension of the drying-maturation stage, application of low-temperature long-time thermal treatments at the end of the manufacturing and the use of high hydrostatic pressure. However, the main drawback of the two first treatments is their duration, while for high hydrostatic pressure treatment, the main inconvenient is the high operating cost. As an alternative, ultrasonically-assisted mild thermal treatments carried out with hot air or water could be an affordable method that could be performed in a shorter period of time and resources saving. Thus, defective hams detected after manufacturing using non-destructive techniques, could be affordably treated to correct pastiness defect, enabling their regular commercialization. 


2. OBJECTIVES 

The main objectives of this doctoral thesis were to evaluate the use of low intensity ultrasound to detect and quantify pastiness in dry-cured ham and to assess the feasibility of the application of mild thermal treatments assisted by high intensity ultrasound to correct this textural defect. In order to achieve these goals, the following particular objectives were established:

1. To assess the feasibility of the ultrasound inspection to monitor non-destructively the development of pastiness during dry-cured ham manufacturing.

2. To evaluate the compositional and textural changes of hams during the post-salting stage in a non-destructive way using ultrasound inspection.

3. To characterize dry-cured ham with different levels of pastiness by sensory, physicochemical, microstructural and ultrasonic analyses.

4. To address the ultrasonic characterization of dry-cured ham texture with contact and air-coupled ultrasound.

5. To explore the viability of using high intensity ultrasound to intensify heat transfer during the mild thermal treatment of dry-cured ham both in water and air media. The effect of temperature and air velocity (air medium) will be considered.

6. To determine the textural and microstructural modifications undergone by dry-cured ham with different levels of pastiness subjected to mild thermal treatments at different temperatures. 

3. METHODOLOGY 



\subsection{Working plan}

The working plan of the present doctoral thesis (Figure 1) was designed in order to reach the objectives initially proposed. Thus, the experimental plan was split into two different tasks giving rise to both chapters in which the results section has been structured. These two tasks correspond to the dry-cured ham textural characterization (Chapter 1) and the use and improvement of mild thermal treatments for the correction of textural defects in dry-cured ham (Chapter 2).

The first chapter encompasses four sections. Firstly, 200 hams were manufactured following a custom process in order to induce pastiness defect in a wide range of intensities. Ham manufacturing was non-destructively monitored by using contact ultrasound at different stages: raw ham, after salting and post-salting and four times during drying-maturation (Chapter 1, Section 1.1). Secondly, the textural modifications during post-salting was analyzed on 8 different hams. For this purpose, the ultrasonic velocity was measured during post-salting (56 days) each 2 days. Every week one of the hams was taken in order to assess instrumentally the changes in texture and composition (Chapter 1, Section 1.2). Thirdly, at the end of the manufacturing process, slices of $2 \mathrm{~cm}$ were taken and analyzed from each of the 200 pieces of custom manufactured ham (from Section 1.1). The texture of the slices was sensory evaluated on Biceps femoris (BF) muscle by an expert panel and the samples were classified depending on their pastiness level in: high, medium and no pastiness. Ham texture was also examined instrumentally and using ultrasound. Furthermore, the composition, the proteolysis index and the microstructure of the hams with different levels of pastiness were also assessed (Chapter 1, Section 1.3). Lastly, the texture of pasty and non-pasty hams was evaluated using contact and air-coupled ultrasound in sliced hams at the end of the manufacturing and compared to instrumental texture (Chapter 1, Section 1.4).

The aim of the second chapter of the Thesis was the improvement of ham texture by using mild thermal treatments and it was subdivided into two sections. The first task of this chapter was to assess the feasibility of using power ultrasound as a strategy to speed up the heat transfer phenomena in solid materials heating (Chapter 2, Section 2.1). The thermal treatments were carried out in two different media: water and air. Firstly, commercial ham slices $(n=18)$ of drycured ham were treated in a water bath at 40,45 and $50{ }^{\circ} \mathrm{C}$ with and without power ultrasound application. During heating, the temperature of the slice was recorded in BF and in Semimembranosus (SM) muscles and the heating kinetics were determined. Secondly, cylindrical samples $(n=48)$ of commercial dry-cured ham from BF and SM muscles were air-forced heated at two different conditions: \#1 constant air velocity $(2 \mathrm{~m} / \mathrm{s})$ at 40,45 and $50{ }^{\circ} \mathrm{C}$ and $\# 2$ constant air temperature $\left(50{ }^{\circ} \mathrm{C}\right)$ at different air velocities $(1,2,3,4$ and $6 \mathrm{~m} / \mathrm{s})$. For both conditions, experiments were carried out with and without power ultrasound application and the temperature 
was recorded in the center of the cylinder. Heat transfer was modelled in both water and air experiments in order to identify how ultrasound affected the apparent thermal diffusivity. After the thermal treatment, textural properties were assessed and compared to the initial ones. The second section of Chapter 2 (Section 2.2) was designed to evaluate the feasibility of conventional and ultrasonically assisted heating to correct texture defects (softness and pastiness) in dry-cured ham. For this purpose, some of the slices of dry-cured ham $(n=108)$ with three levels of pastiness (high, medium and no pastiness) mentioned previously in section 1.3 were thermally treated with and without ultrasound assistance in a water bath during 5 hours at two different temperatures (40 and $50{ }^{\circ} \mathrm{C}$ ). In ultrasonic experiments, samples were only submitted to sonication in the heating phase while the holding stage was performed without ultrasonic assistance. After the treatment, the texture of the slices of dry-cured ham was instrumentally analyzed and hardness, the elastic behavior and adhesiveness were computed. The changes on the microstructure of dry-cured ham after the thermal treatment were also evaluated by using light and transmission electron microscopy. 


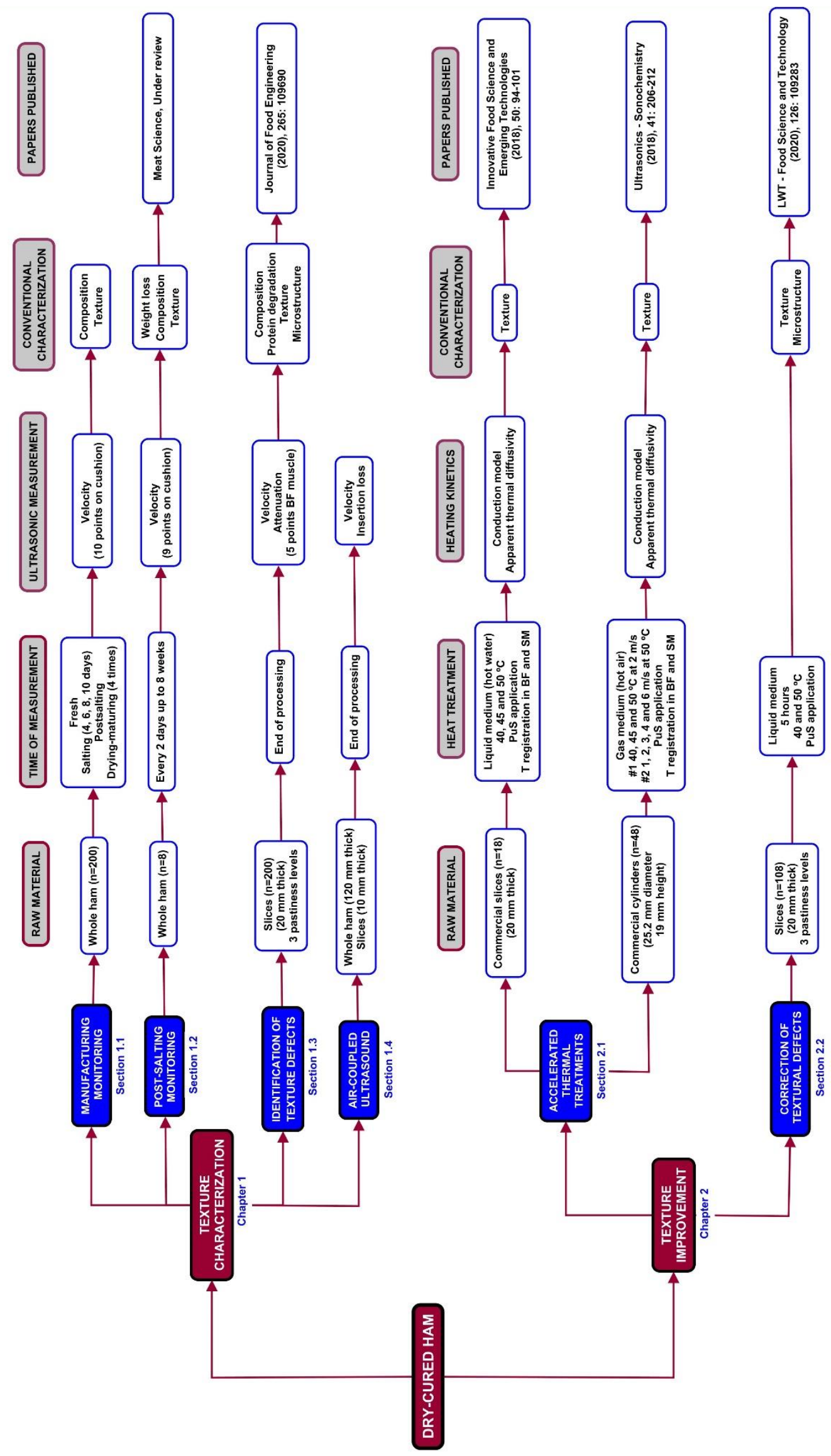

Figure 1. Working plan 


\subsection{Raw material and sample preparation}

The origin of the dry-cured ham used during this thesis was different depending on the experiments carried out. For sections 1.1, 1.3 and 2.2, raw hams from Large White and Landrace pig breed crosses were provided by a local supplier (Girona, Spain) and manufactured in the IRTA-Research \& Technology Food \& Agriculture Institute (Girona, Spain). A customized elaboration process was performed in order to induce pastiness at different intensities in a broad range of salt contents. Firstly, hams were salted for 4, 6, 8 or 11 days without considering the ham weight. Secondly, post-salting of hams was carried out for a time longer than the standard (100 days) in order to avoid microbiological risks. Thirdly, during the drying-maturation period, hams were dried until reducing their weight by $29 \%$ and subsequently they were vacuum-packed and kept at $30{ }^{\circ} \mathrm{C}$ for 30 days in order to induce high proteolysis levels. Afterwards, the hams were unwrapped and subjected to a second drying process, which was extended until a final average weight loss of 34\% was reached in each piece. Subsequently, the hams were vacuum-packed and kept at $30{ }^{\circ} \mathrm{C}$ for 30 days. Finally, the unwrapped hams were dried until a final average weight loss of 36\% was attained. For the monitoring of dry-cured ham manufacturing (Section 1.1), the whole hams were used. While for the identification of texture defects (Section 1.3) and for the correction of texture defects in dry-cured ham (Section 2.2), slices of different thickness (1.5 and $20 \mathrm{~mm}$ ) from the aforementioned hams were used depending on the analysis (sensory, ultrasonic or instrumental texture, chemical or microstructural) to be performed. The slices were vacuumpacked in plastic film and stored at $4{ }^{\circ} \mathrm{C}$ until analyzed. At the end of the manufacturing, a sensory analysis was carried out to characterize the level of ham pastiness.

For post-salting monitoring (Section 1.2), green hams from Landrace-Large White and Danish Duroc pig breed crosses were provided by a local supplier (Valencia, Spain). Hams were salted 1 day per kg of weight and afterwards hams were hung up 56 days at $2{ }^{\circ} \mathrm{C}$ and $80-85 \%$ of relative humidity for the post-salting stage.

The experiments with contact and air-coupled ultrasound (Section 1.4) were carried out on standard dry-cured hams (whole and slices of different thickness: 120 and $10 \mathrm{~mm}$ ) from Landrace and DanBred pig breed crosses provided by a local supplier (Cuenca, Spain).

Finally, the origin of the samples used for the mild thermal treatments of dry-cured ham (Section 2.1) was different depending on the medium where the samples were treated. Thus, for water treatments, slices of dry-cured ham (10 mm thick) from Large White breed pigs were purchased from a local supplier (Girona, Spain) from deboned commercial pieces. Regarding airforced treatments, cylindrical samples (20 mm height and $25.2 \mathrm{~mm}$ diameter) were taken from the BF and SM muscles of slices of dry-cured ham. In this case, dry-cured ham slices came from Large White breed pigs provided by the IRTA-Research \& Technology Food \& Agriculture 
Institute (Girona, Spain). Both the slices and the cylinders of dry-cured hams were vacuumpacked in plastic film and kept in refrigeration $\left(4^{\circ} \mathrm{C}\right)$ until heating experiments were performed.

\subsection{Ultrasonic analysis}

Non-destructive testing ultrasound (NDT-ultrasound) technologies were used for the textural characterization of dry-cured ham (Chapter 1). In this section, the ultrasonic equipment and the measurement mode will be described briefly. More details on the ultrasonic technologies and how they were used in each particular analysis can be found in the Materials \& Methods section of each paper that make up the Results section of this thesis.

The ultrasonic equipment used in this Thesis consists of an actuator, a pair of transducers, a pulser-receiver, a digital oscilloscope, a computer and a controller (Figure 2). For performing the ultrasonic measurement, an electrical wave is generated in the pulser-receiver (Figure 2, (4)) and supplied to the emitter transducer (Figure 2, (2)), which transforms the electrical wave in an ultrasonic mechanical wave. The ultrasonic wave, travels through the sample and arrives to the receiver transducer (Figure 2, (3), which transforms the mechanical wave in an electrical signal. Subsequently, the signal is filtered and amplified in the pulser-receiver, digitized in the oscilloscope (Figure 2, 5), and sent to the computer (Figure 2, 6) for further analysis. The computer also sends the information to the controller (Figure 2, 7) to manage the position of the emitter transducer that is attached at the bottom of the actuator (Figure 2, (1)).

(6) COMPUTER

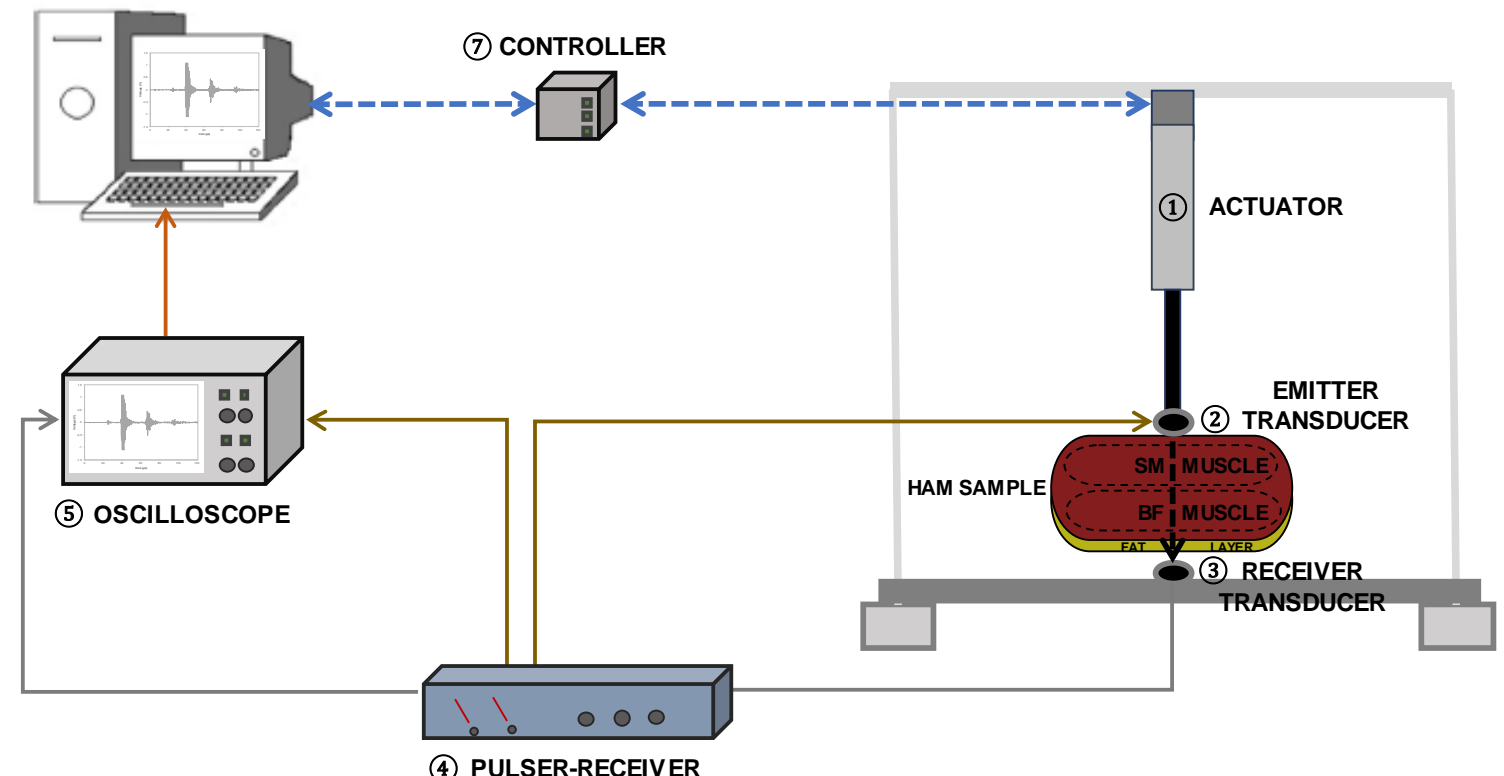

Figure 2. Diagram of the ultrasonic experimental set-up. 
Two different kinds of transducers were used: contact and air-coupled transducers. When the contact transducers were utilized, the sample was placed in between both transducers in contact with the ham sample. The measurement was taken in through-transmission mode (the signal travelled from the emitter transducer to the receiver transducer) with the purpose of measuring longitudinal waves (Figure 3, A). In order to obtain a good coupling between the transducers and the sample, coupling materials, like water or oil, were used when needed. By contrast, when the air-coupled transducers were utilized, the sample was placed in between both transducers without touching the ham sample. In order to minimize the energy losses due to the impedance decoupling between the transducer and the air, different matching layers are incorporated in the construction of these transducers (Gómez Álvarez-Arenas, 2013). Two different modes of measuring were used for the air-coupled transducers: through-transmission (Figure 3, B) and pulse-echo (Figure 3, C). As previously mentioned, with the throughtransmission mode, longitudinal waves were measured while with the pulse-echo mode, the propagation of longitudinal and shear waves in dry-cured ham was tested. In Figure 4, contact and air-coupled ultrasound configurations are shown.

\section{A}
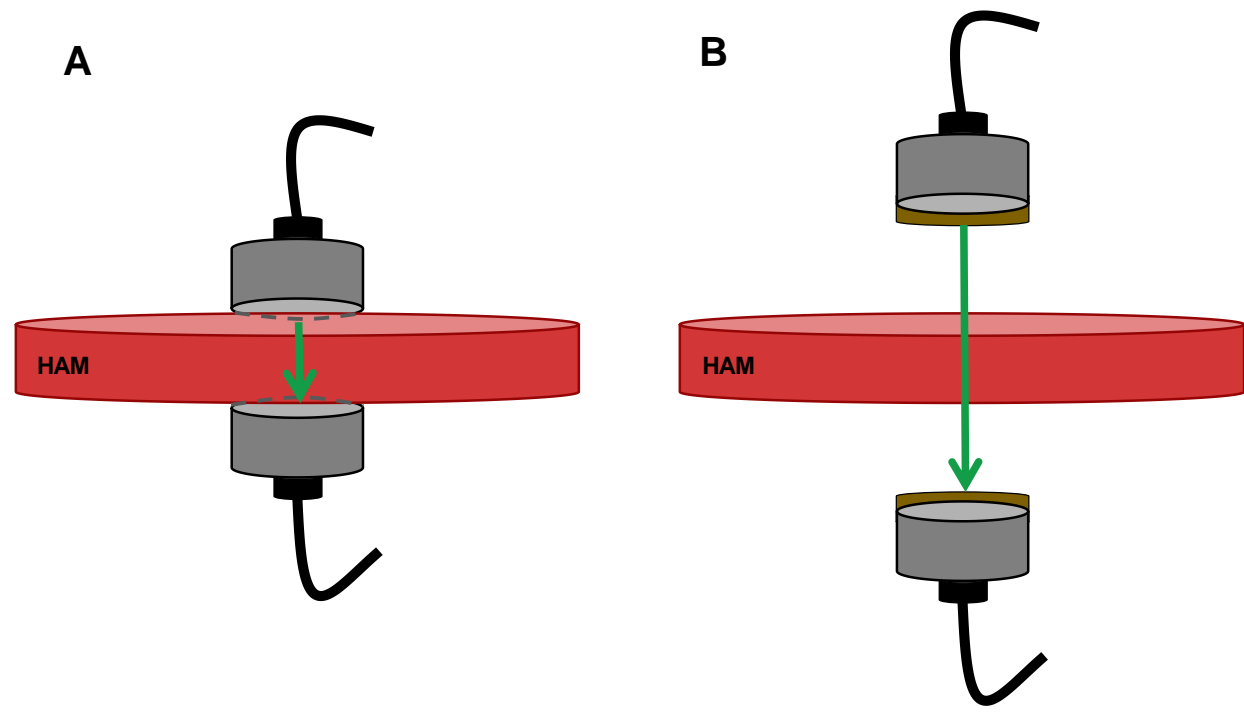

C

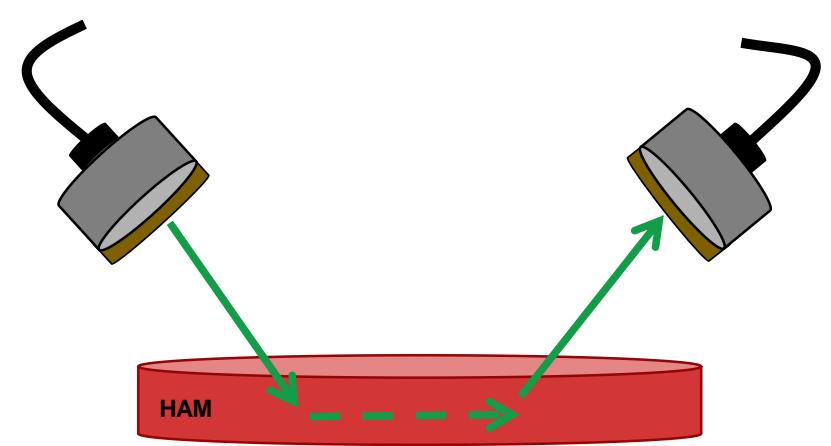

Figure 3. Experimental configuration depending on the transducers and mode of measurement used. A: contact transducers in through-transmission mode; B: air-coupled transducers in throughtransmission mode; $\mathrm{C}$ : air-coupled transducers in pulse-echo mode. 

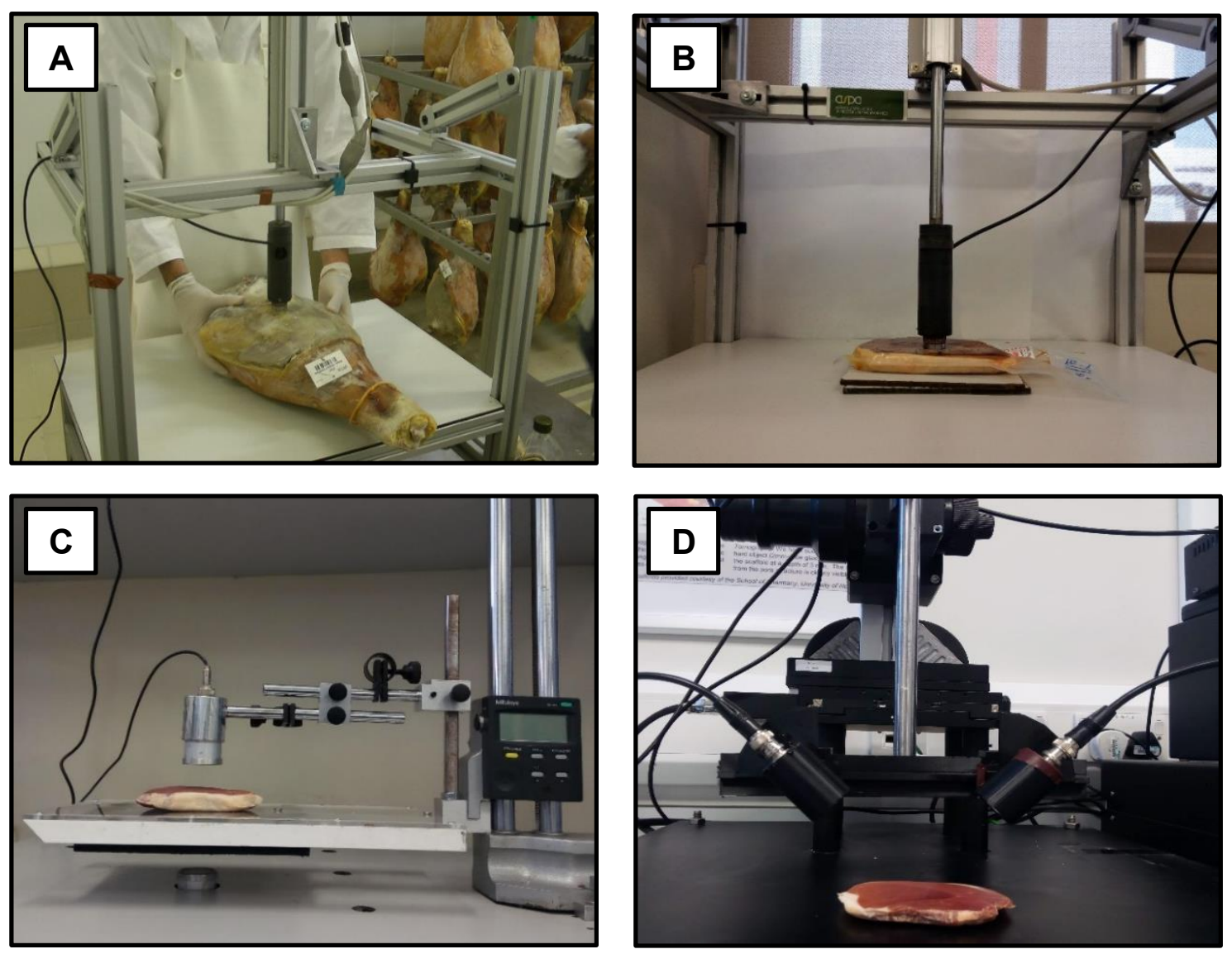

Figure 4. Contact ultrasound testing of whole ham (A) and sliced dry-cured ham (B), both in throughtransmission mode. Air-coupled ultrasound testing of sliced dry-cured ham in through-transmission mode (normal incidence) (C) and in pulse-echo mode(normal and oblique incidence) (D).

Depending on the measurement method (contact or air-coupled ultrasound) and on the thickness of the measured sample (whole or sliced ham), the ultrasonic signals obtained and the ultrasonic parameters determination were different. Thus, in the contact ultrasound testing, the ultrasonic velocity (speed of the ultrasonic wave when passing through a material) was measured by the energy threshold method. For that purpose, the ultrasonic velocity ( $V$ ) (Eq. 1) was computed in the time domain as the ratio between the sample thickness $(h)$ and the time of flight (TOF) of the ultrasonic wave when passing through the sample, calculated by the energy threshold method (difference between the trigger time and the time when the signal exceeds a particular energy threshold) (Garcia-Perez et al., 2019).

$$
V=\frac{h}{T O F}
$$

In the contact measurements, the ultrasonic attenuation, which could be described as the loss of energy of the ultrasonic wave when passing through a material, was also analyzed. For the 
ultrasonic attenuation calculation, the analysis was performed in the frequency domain by applying the Fast Fourier Transform (FFT) to the time domain signal. Data in the frequency domain consisted of a module spectrum (amplitude) and a phase spectrum (frequency). From there, the attenuation coefficient $(\alpha)$ (Eq. 2) was calculated as the ratio between the maximum amplitude of the module spectrum of two consecutive peaks $\left(A / A_{0}\right)$ of the signal and the sample thickness $(h)$.

$$
\alpha=\frac{\operatorname{Ln}\left(\frac{A}{A_{0}}\right)}{2 h}
$$

For the air-coupled ultrasound testing, the ultrasonic velocity was calculated by both the energy threshold method (described previously) and the cross-correlation method (Leemans \& Destain, 2009). For this purpose, the reference signal (ultrasonic signal without sample between transducers) was cross-correlated with the sample signal (ultrasonic signal with sample between transducers) and the difference in the time of flight between both signals was used to calculate the ultrasonic velocity from Eq. 3 (Gómez Álvarez-Arenas, 2010):

$$
V=\frac{h}{\frac{h}{v_{a}}-\Delta T O F}
$$

where $h$ is the thickness of the sample, $v_{a}$ is the ultrasonic velocity in the air and $\triangle T O F$ is the time of flight difference between the sample signal and the reference signal.

The velocity of an ultrasonic wave traveling through a material is constant for a homogeneous medium and only depends on it physic properties: elastic or Young modulus $(E)$ and density ( $\rho$ ) (Eq. 4) (Mulet et al., 1999). As the Young modulus and density depends on the structure, composition and physical status of a material, the ultrasonic velocity measurement could provide information about those properties (McClements, 1997). Likewise, the loss of energy of the ultrasonic wave when passing through a material, calculated from the attenuation coefficient, could also contribute to describe the structure or physical status of the material.

$$
V=\sqrt{\frac{E}{\rho}}
$$




\subsection{Thermal treatments}

\subsubsection{Experimental set-up}

The influence of mild heat treatments on the textural changes of dry-cured ham were assessed in Chapter 2. The application of power ultrasound (PuS) during heating was also evaluated. The treatments were carried out in two different mediums (water and air). For the experiments carried out in water, the experimental set-up consisted of an ultrasonic bath with water where the dry-cured ham slice was introduced (Figure 5, A). An on-off controller connected to both a heater and a chiller was utilized to keep the water temperature constant, especially when $\mathrm{PuS}$ were applied, due to the heat generation linked to ultrasonic cavitation.

For the experiments carried out in air, the experimental set-up consisted on an ultrasonically assisted air-force heater. The cylindrical sample of dry-cured ham was hung on a sample holder and placed in the middle of the treatment chamber (an aluminum cylinder) (Figure 5 , B). The hot air was forced to pass from the bottom to the top of the treatment chamber, surrounding the ham sample. In the treatments assisted with $\mathrm{PuS}$, the ultrasonic waves were transmitted from the walls of the treatment chamber to the air, finally reaching the sample.
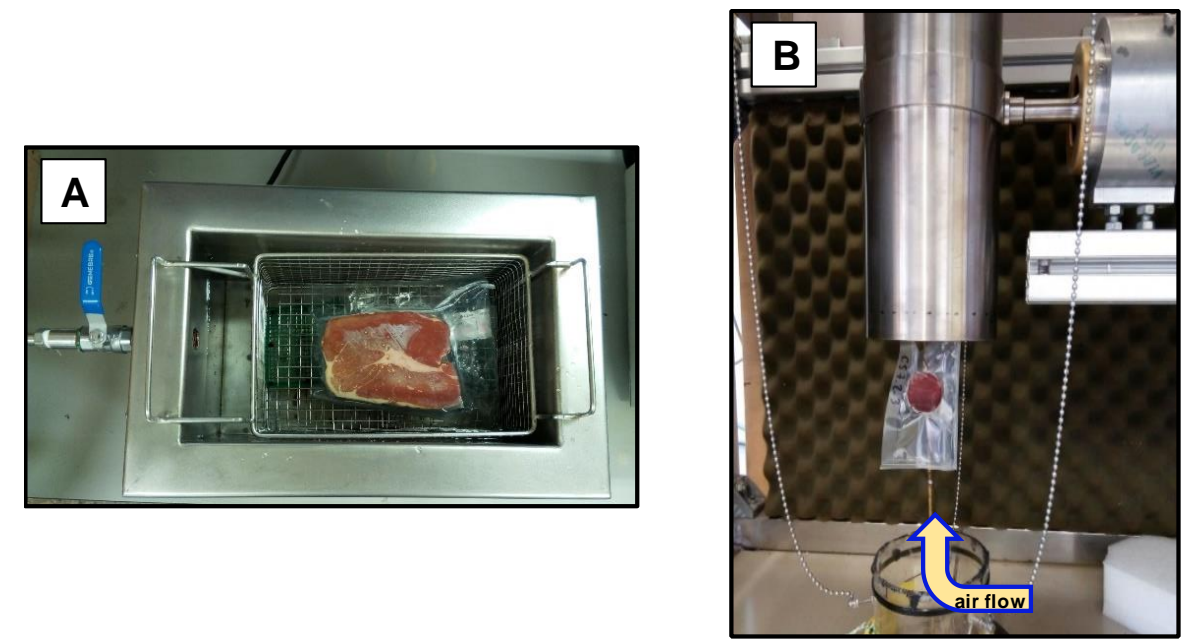

Figure 5. Ultrasonic bath (A) and ultrasonic assisted air-forced treatment chamber (B) for mild thermal treatments of dry-cured ham.

\subsubsection{Thermal treatments modelling}

In Chapter 2, Section 2.1, the heating of the dry-cured ham was monitored with the assistance of four thermocouples placed at 10 and $5 \mathrm{~mm}$ from the surface of BF and SM muscles of the slices and in the geometrical center of the cylinders. Modeling was used to quantify the effect of the process variables (application of PuS, medium temperature and air velocity) on the 
ham heating kinetics. For that purpose, a mathematical model that considered heat transfer entirely controlled by conduction was chosen. Dry-cured ham was supposed to be homogeneous, isotropic, assuming negligible contraction and constant apparent thermal diffusivity and considering the ham slice as an infinite slab and the cylindrical ham shape as a finite cylinder. The Eqs. 5 and 6 show the conduction models used for modeling the heating kinetics of dry-cured ham slices and cylinders, respectively (Holman, 1986):

$$
\begin{gathered}
T_{(x, t)}=T_{\infty}+\left(T_{0}-T_{\infty}\right)\left(2 \sum_{n=0}^{\infty} \frac{(-1)^{n}}{\beta_{n} L} e^{-\alpha \beta_{n}^{2} t} \cos \left(\beta_{n} x\right)\right) \\
\frac{T_{(\mathrm{x}, \mathrm{r}, \mathrm{t})}-T_{\infty}}{T_{0}-T_{\infty}}=\left(2 \sum_{\mathrm{n}=0}^{\infty} \frac{(-1)^{\mathrm{n}}}{\beta_{\mathrm{n}} \mathrm{L}} \mathrm{e}^{-\alpha \beta_{\mathrm{n}}^{2} \mathrm{t}} \cos \left(\beta_{\mathrm{n}} \mathrm{x}\right)\right)\left(2 \sum_{\mathrm{n}=1}^{\infty} \frac{\mathrm{e}^{-\alpha \lambda_{\mathrm{n}}^{2} \mathrm{t}}}{\lambda_{\mathrm{n}} \mathrm{RJ}_{1}\left(\lambda_{\mathrm{n}} \mathrm{R}\right)} \mathrm{J}_{0}\left(\lambda_{\mathrm{n}} \mathrm{r}\right)\right)
\end{gathered}
$$

where $T_{0}$ is the initial temperature $\left({ }^{\circ} \mathrm{C}\right)$ of dry-cured ham, $T_{\infty}$ is the water or air heating medium temperature ( $\left.{ }^{\circ} \mathrm{C}\right), \beta_{n}$ are the eigenvalues calculated as $\beta_{n}=(2 n+1) \frac{\pi}{2 L}, L$ is the half-thickness (m) of the slice (Eq. 5) or cylinder (Eq. 6), $\alpha$ is the apparent thermal diffusivity $\left(\mathrm{m}^{2} / \mathrm{s}\right), t$ is the time (s), $x$ is the axial direction (m), $\lambda_{n}$ are the eigenvalues calculated as $\lambda_{n} / J_{0}\left(\lambda_{n} R\right)=0, R$ is the cylinder radius (m), $J_{v}$ is Bessel function of first kind of order $v$ and $r$ is the radial direction (m).

The apparent thermal diffusivity $(\alpha)$ was identified by fitting the Eq. 5 and 6 to the heating kinetics and by minimizing the sum of the squared differences between the experimental and calculated temperature. The goodness of the fit was assessed by calculating the percentages of explained variance (VAR, Eq. 7) and the mean relative error (MRE, Eq. 8):

$$
\begin{aligned}
& \operatorname{VAR}(\%)=\left[1-\frac{S_{x y}^{2}}{S_{y}^{2}}\right] \cdot 100 \\
& \operatorname{MRE}(\%)=\frac{\sum_{\mathrm{i}=1}^{N} \frac{\left|T_{\mathrm{ei}}-\mathrm{T}_{\mathrm{ci}}\right|}{\mathrm{T}_{\mathrm{ei}}}}{\mathrm{N}} \cdot 100
\end{aligned}
$$

where $S_{x y}$ and $S_{y}$ are the standard deviation of the estimation and the sample, respectively, $T_{e i}$ and $T_{c i}$ are the experimental and calculated temperature and $N$ is the number of experimental data. A more detailed information about the systems used for heat treatments in water and air media and about the modelling can be found in the Materials \& Methods sections of Chapter 2, section 2.1. 


\subsection{Instrumental and sensory characterization}

\subsubsection{Salt content}

In order to determine the salt content, $1 \mathrm{~g}$ of ground dry-cured ham was homogenized with $80 \mathrm{~mL}$ of Milli-Q water using an ultraturrax (T25, IKA Labortechnik, Germany) at $9500 \mathrm{rpm}$ during $5 \mathrm{~min}$. The extract obtained was filtered and $1 \mathrm{~mL}$ of $\mathrm{HNO}_{3}$ was added. A titration of the extract was done with $\mathrm{AgNO}_{3} 0.1 \mathrm{~N}$ using a potentiometric titrator 785 DMP Titrino (Metrohm AG, Herisau, Switzerland) following the standard method (ISO1841-2, 1996). The grams of salt were calculated from the $\mathrm{mL}$ of $\mathrm{AgNO}_{3}$ spent in the titration. The results were expressed as a percentage of $\mathrm{NaCl}$ on a wet basis (w.b., $\mathrm{kg}$ salt/100kg total matter).

\subsubsection{Moisture content}

Moisture content was determined following the standard AOAC method 950.46 (AOAC, 1997). Thus, $2 \mathrm{~g}$ of ground ham were introduced in an oven at $102{ }^{\circ} \mathrm{C}$ until reaching a constant weight $(24 \mathrm{~h})$. The moisture content was expressed as a percentage on a wet basis (w.b., $\mathrm{kg}$ water/100 kg total matter).

\subsubsection{Proteolysis index}

The proteolysis index is a parameter related with the degree of protein cleavage, since it is computed as the ratio between the non-protein nitrogen (NPN) and the total nitrogen (TN) of the sample. In order to calculate the NPN content, $2.5 \mathrm{~g}$ of ground dry-cured ham from BF muscle were homogenized with $25 \mathrm{~mL}$ of distilled water using an ultraturrax (T25, IKA Labortechnik, Germany). In the extract, the proteins were precipitated with $10 \mathrm{~mL}$ of trichloroacetic acid (20 $\%$ ). After centrifuging and filtering the extract, $15 \mathrm{~mL}$ were used to analyze the remaining NPN with the standard Kjeldahl method (ISO937, 1978). The total nitrogen content was determined using also the procedure stablished in the standard Kjeldahl method (ISO937, 1978). The proteolysis index was expressed as a percentage of NPN regarding the total nitrogen content (NPN/TN, \%).

\subsubsection{Texture}

\section{Simple compression test}

From a simple compression test, ham hardness was evaluated. A texturometer (TA-XT2, SMS, Godalming, UK) was programmed to carry out a simple compression of a ham parallelepiped ( $20 \times 20 \times 15 \mathrm{~mm}$ length $\mathrm{x}$ width $\mathrm{x}$ height $)$ with a cylindrical flat probe $(10 \mathrm{~mm}$ diameter) to $25 \%$ of its height (crosshead speed of $1 \mathrm{~mm} / \mathrm{s}$ ) (Figure 6). From the force versus time 
profile obtained (Figure 7), the hardness of the ham was computed as the maximum force achieved.

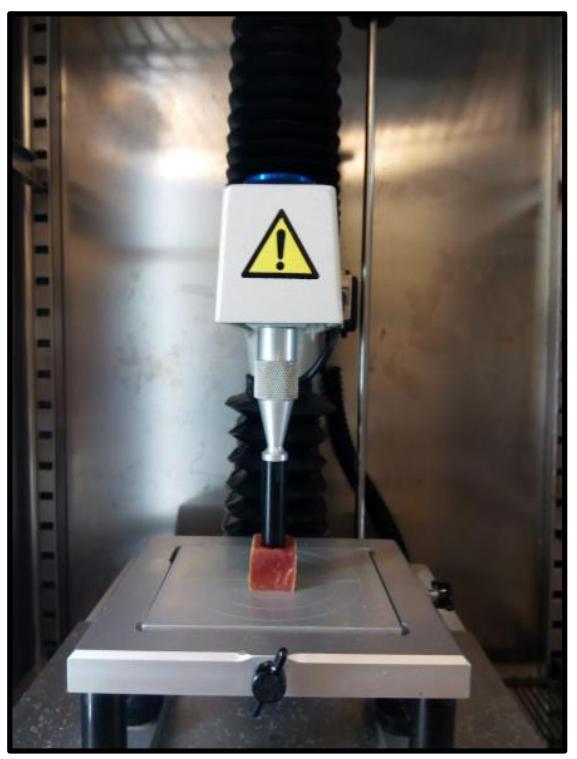

Figure 6. Simple compression test carried out on ham parallelepipeds with a cylindrical probe.

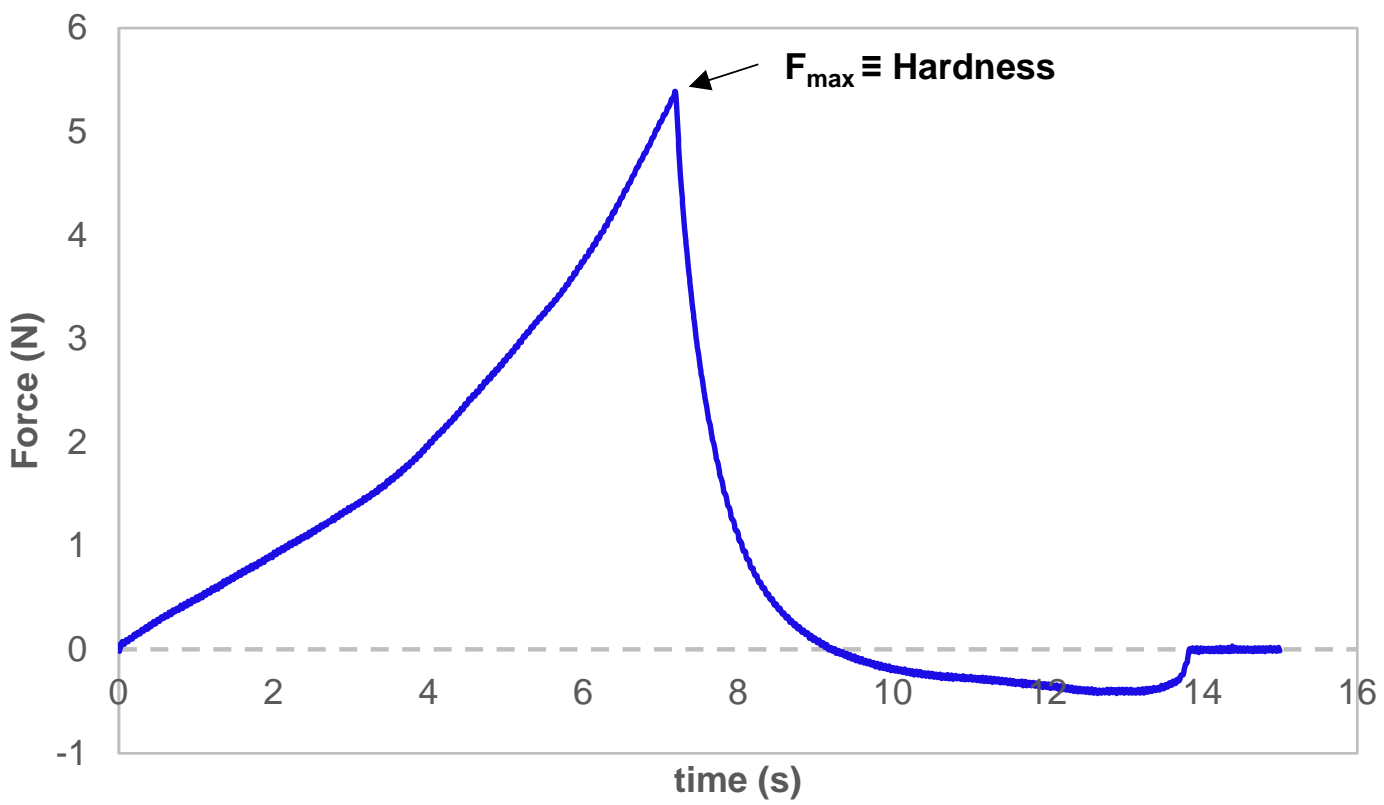

Figure 7. Characteristic force-time profile obtained by simple compression tests in ham. 


\section{Stress-relaxation test}

From a stress-relaxation test, dry-cured ham hardness and its elastic behavior was also evaluated. The texturometer was programmed to compress a dry-cured ham parallelepiped $(20 \mathrm{x}$ $20 \times 15$ mm length x width $\mathrm{x}$ height) in Chapter 1, Section 1.3 and in Chapter 2, Section 2.2 while in Chapter 2, Section 2.1 dry-cured ham cylinders (20 and $25.2 \mathrm{~mm}$ in diameter for water and air treatments, respectively, and $20 \mathrm{~mm}$ in height) were used. Both shapes were compressed (crosshead speed of $1 \mathrm{~mm} / \mathrm{s}$ ) with a cylindrical flat probe ( $75 \mathrm{~mm}$ diameter) to $25 \%$ of the initial height during $90 \mathrm{~s}$ (Figure 8). From the force versus time profile obtained (Figure 9), the hardness and the elastic behavior of the ham was computed. Thus, hardness was calculated as the maximum force achieved $\left(F_{\max }=F_{0}\right)$, while the relaxation capacity was assessed as the level of force decay $\left(Y_{t}\right)$, which is inversely proportional to the elastic behavior of the ham. $Y_{t}$ was calculated as the ratio between the difference of the maximum force and the force registered at time $t$ ( 2 or $90 \mathrm{~s}$ ) of the relaxation period, and the maximum force (Eq. 9).

$$
Y_{t}=\frac{F_{0}-F_{t}}{F_{0}}
$$

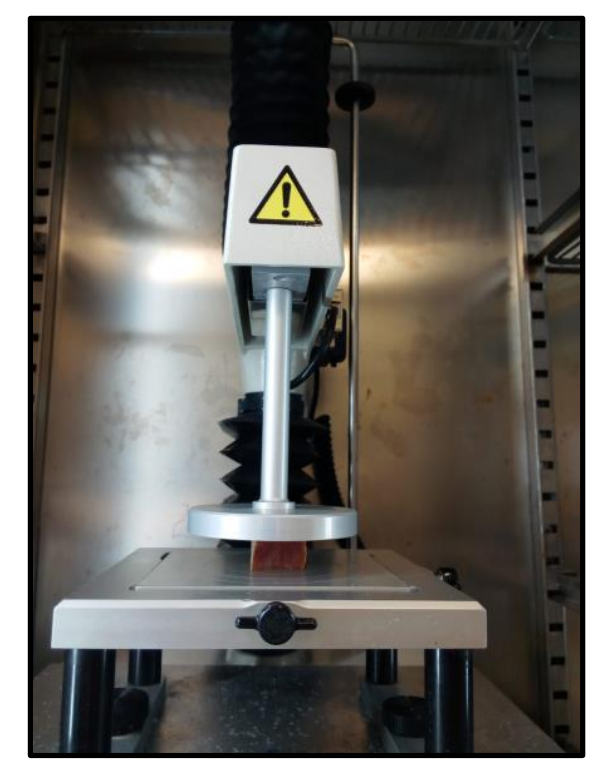

Figure 8. Stress-relaxation test carried out on dry-cured ham parallelepipeds with a cylindrical probe ( $75 \mathrm{~mm}$ of diameter). 


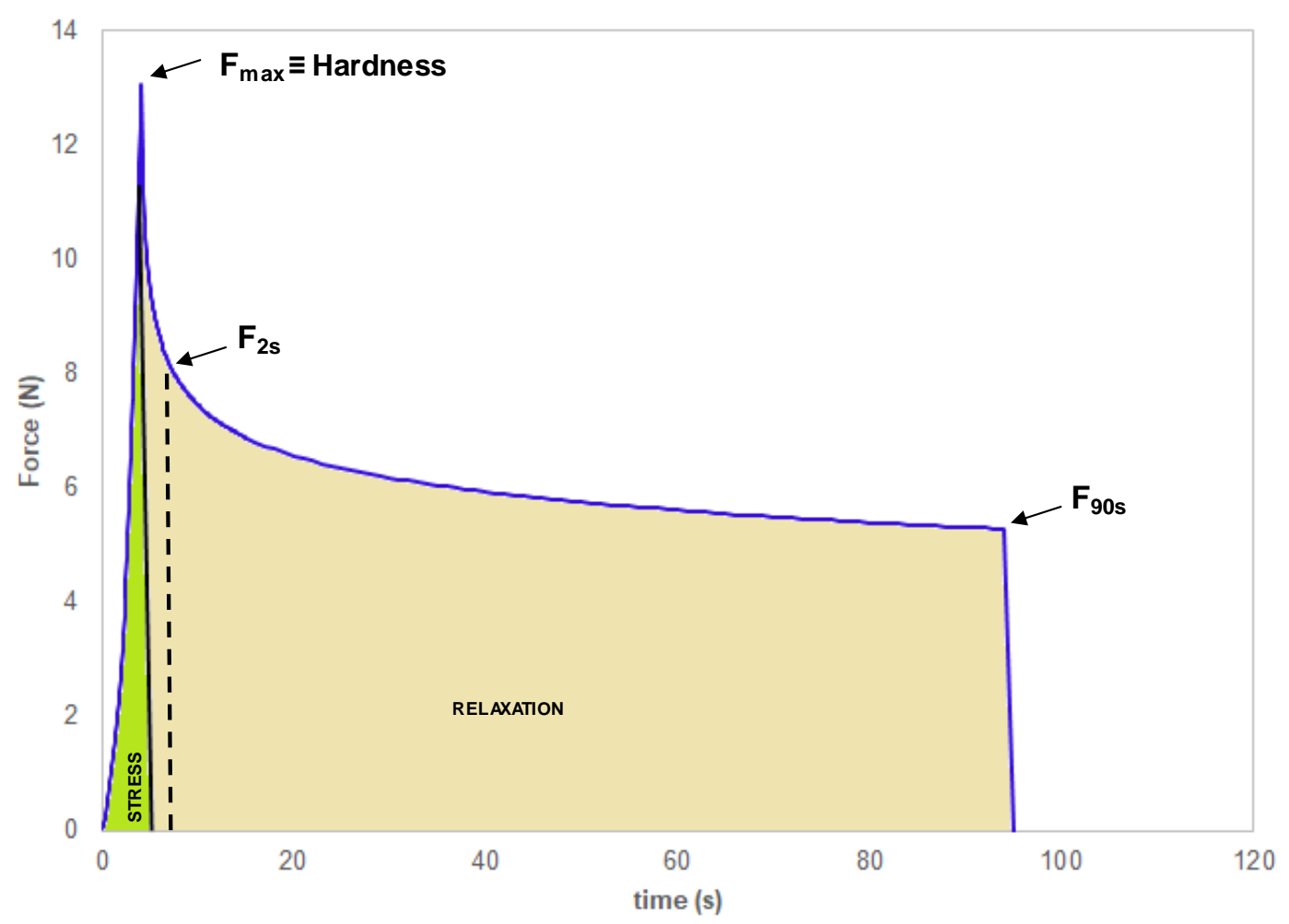

Figure 9. Characteristic force-time profile obtained by a stress-relaxation test in dry-cured ham.

\section{Separation test}

From a separation test, dry-cured ham adhesiveness was evaluated in dry-cured ham slices. A texturometer (TA-XT Plus, London, UK) was programmed to separate two thin slices $(1.5 \mathrm{~mm}$ ) displacing horizontally a clamp probe $100 \mathrm{~mm}$ (crosshead speed of $0.5 \mathrm{~mm} / \mathrm{s}$ ) (Figure 10). From the force versus time profile obtained (Figure 11), the adhesiveness of the ham was computed as the maximum force achieved.

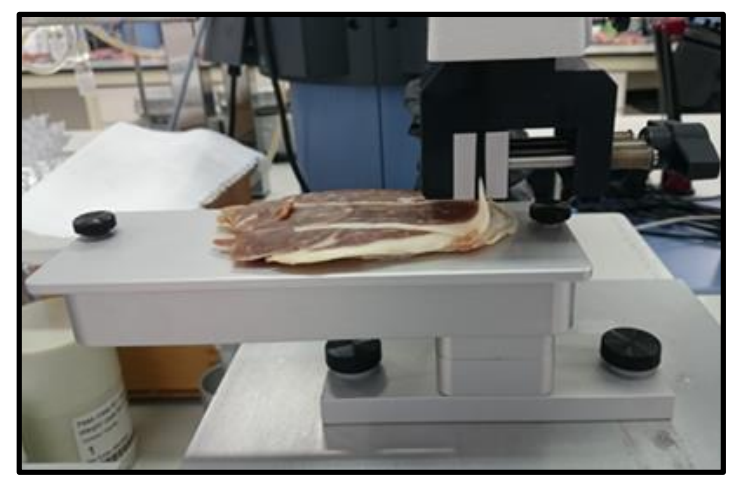

Figure 10. Separation test carried out on dry-cured ham slices with a clamp probe. 


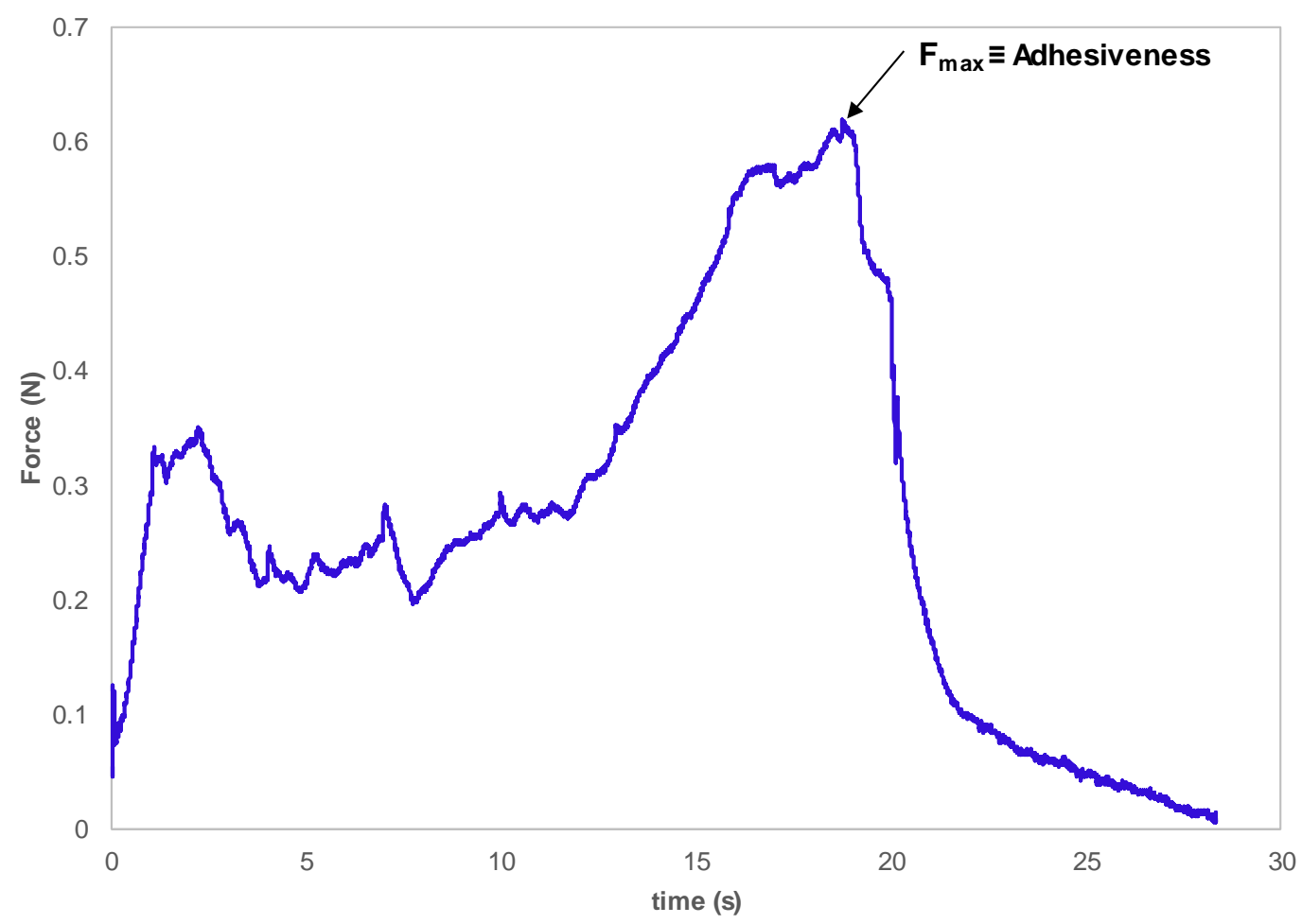

Figure 11. Characteristic force-time profile obtained by a separation test in dry-cured ham.

\section{Sensory analysis}

A three-member panel trained following the American Society for Testing and Materials (ASTM STP 758, 1981) performed the sensory texture analysis of the dry-cured ham samples. The sensory attribute evaluated was the pastiness in BF muscle, ranked from score 0 (absence) to 6 (maximum intensity). The average score of the three experts was set as the pastiness of the drycured ham analyzed, classifying the samples into three levels of pastiness: non-pasty (pastiness level < 1), medium-pasty (pastiness level between 1 and 2.5) and highly-pasty (pastiness level > 2.5).

\subsubsection{Microstructure analysis}

The microstructure of BF muscle from dry-cured ham with different levels of pastiness and from normal ham was observed by light microscopy (LM) and by transmission electron microscopy (TEM). The microstructure of dry-cured ham after receiving a thermal treatment was also observed with the same microscopy techniques. For the sample preparation, small sections of ham $(5 \times 3 \mathrm{~mm})$ were cut from BF muscle and fixed with a glutaraldehyde solution, postfixed with osmium tetroxide, dehydrated using a graded acetone series, contrasted with uranyl acetate 
dissolved in acetone and embedded in epoxy resin. The included sections were cut with an ultramicrotome (Leica Mycrosystems, Wetzlar, Germany) in thin $(1.5 \mu \mathrm{m})$ and ultrathin sections $(0.5 \mu \mathrm{m})$. The thin sections were stained with toluidine blue and examined with a light microscope (Nikon Eclipse E800, Tokyo, Japan), while the ultrathin sections were stained with lead citrate and observed with a transmission electronic microscope (Philips EM400, Eindhoven, Holland). More details on how the microstructure analysis were done can be found in the Materials \& Methods section of Chapter 1, Section 1.3 and Chapter 2, section 2.2. 


4. RESULTS AND DISCUSSION 



\section{CHAPTER 1}

\section{Ham Texture Characterization}





\title{
Ultrasonic monitoring of dry-cured ham manufacturing as a strategy to predict the appearance of pastiness defect
}

\author{
Marina Contreras, Jose Benedito, Jose Vicente Garcia-Perez
}

Grupo de Análisis y Simulación de Procesos Agroalimentarios (ASPA). Departamento de Tecnología de Alimentos. Universitat Politècnica de València. Camí de Vera s/n, Valencia (46022), Spain. 



\title{
Ultrasonic monitoring of dry-cured ham manufacturing as a strategy to predict the appearance of pastiness defect
}

\begin{abstract}
Dry-cured ham is a high quality product susceptible of presenting a great variability at the end of the manufacturing depending on the intrinsic parameters of the raw ham as well as the operational variables. Pastiness is a relevant textural defect detrimental to quality, which is characterized by an intense viscous behavior and excessive softness. There is no evidence of the moment in which pastiness appears during ham manufacturing. Ultrasonic velocity has been used to monitor several food processes in addition, its ability to characterize textural parameters in meat products has been reported. Thus, for the first time, this work addresses the detection of the pastiness appearance in whole ham pieces during its manufacturing using low intensity ultrasound, as well as its discrimination at the end of manufacturing depending on the pastiness level. For this purpose, two hundred hams followed a customized manufacturing in order to induce pastiness at different levels. A customized ultrasonic device was used to measure the ultrasonic velocity at different moments during manufacturing, in the raw, salted and post-salted hams, three moments during the drying-maturation and at the end of manufacturing. The salt content and the pastiness level were measured at the end of the manufacturing (instrumentally and sensory assessed, respectively). As the manufacturing proceeded, a gradual increase in ultrasonic velocity was found, mainly because of the salt gain and water loss. A significant $(\mathrm{p}<0.05)$ relationship was found between the salt content and the ultrasonic velocity $(r=0.58)$ at the end of manufacturing, where the higher the salt content, the greater the velocity. No significant differences ( $p>0.05)$ were found on the ultrasonic velocity depending on the pastiness level of the ham. The discriminant analysis performed with the ultrasonic velocity was able to classify correctly only the $43.3 \%$ of the hams according to its pastiness level. Thus, the ultrasonic velocity cannot be considered as an appropriate parameter nor to detect the appearance of pastiness during manufacturing neither to distinguish between hams with different levels of pastiness at the end of manufacturing.
\end{abstract}

Keywords: dry-cured ham, manufacturing, ultrasonic velocity, pastiness, detection. 


\section{Introduction}

Dry-cured ham quality is affected not only by the raw material used but also by the manufacturing process. Among the intrinsic factors, it is worth mentioning the ham size (Parolari, 1996), pH (Guerrero et al., 1999; Ruiz-Ramírez et al., 2006), composition (RuizCarrascal et al., 2000), breed (Gou et al., 1995) or animal castration (Bañón et al., 2003). As for the manufacturing process factors, the ratio salt/ham weight employed during salting (Martín et al., 1998; Ruiz-Ramírez et al., 2005) and the temperature, relative humidity and length of the different stages are some of the most relevant ones. The proper selection of all these parameters is of great importance, since they are responsible of the final ham quality and, in particular, an incorrect choice can lead to the appearance of texture defects. Specifically, one of the main texture problems in dry-cured ham is the so-called pastiness, which is defined as a feeling similar to the mouth-coating sensation produced by flour-water paste during the mastication process and is characterized by an intense viscous behavior and excessive softness (Parolari et al., 1994). The appearance of pastiness has been mainly related to a low salt content, the use of high temperatures during processing and $\mathrm{pH}$ out of a standard range (5.7-6.2). Currently, the precise moment of the appearance of this defect during the manufacturing process is uncertain. Hence, the early detection of ham pastiness is of paramount interest in order to avoid the defect to further development.

Various technologies have been used for the non-destructive assessment of dry-cured ham texture. Some of them are based on electromagnetic waves, such as near infrared spectroscopy (NIR) (García-Rey et al., 2005), time domain reflectometry (TDR) (Rubio et al., 2013), X-Rays (Fulladosa et al., 2018) or laser-light backscattering (LBI) (Fulladosa et al., 2017). Electrical Impedance Spectroscopy (EIS), which is based on the application of a sinusoidal test voltage or current to the sample under test, has also been explored for the identification of the ham texture in a non-destructive way (Guerrero et al., 2004). However, some of the main drawbacks of these electromagnetic or electrical technologies are the high initial investment, the complex calibration or the limited penetration into the sample, allowing to obtain only information from the sample surface. Alternatively, the use of mechanical waves, such as ultrasound, have also been applied to evaluate some textural changes in ham. Compared to the electromagnetic technologies, the advantages of the ultrasonic waves are the higher penetration capacity and the non-ionizing nature. Thus, Corona et al. (2013) applied satisfactorily the use of ultrasound to detect textural changes in sliced dry-cured ham after a high hydrostatic pressure treatment or a cold storage. Likewise, Contreras et al. (2020) used ultrasound to classify sliced dry-cured ham according to its pastiness level. Most of the technologies mentioned previously have been applied to dry-cured ham slices, when the ham manufacturing is already finished. In this sense, the implementation of this technologies to the whole ham would allow the monitoring of textural changes during manufacturing. In the case of 
pastiness appearance, its development could be prevented by modifying the time, temperature or relative humidity of the subsequent stages if the defect is detected in the early stages. Furthermore, the detection of pastiness in whole hams at the end of the manufacturing could avoid the commercialization of defective dry-cured hams. In this context, the main objective of this study was to non-destructively detect the appearance of pastiness during the manufacturing of dry-cured ham by means of ultrasound, as well as to classify the hams according to their texture at the end of the manufacturing.

\section{Materials and methods}

\subsection{Raw material}

Raw hams ( $\mathrm{n}=200)$ from Large White and Landrace animal breed crosses were used (average weight of $11.9 \pm 1.1 \mathrm{~kg}$ ). Hams followed a customized elaboration process in order to induce pastiness over a wide intensity range, as described in detail by Contreras et al. (2020). Hams were salted at different times: 4, 6, 8 and 11 days, which represents a shorter salting time than the standard (1-1.5 days/kg of ham) (Barat et al., 2004). In addition, hams were rubbed with a lower amount of salts (including $10 \mathrm{~g}$ of $\mathrm{NaCl} / \mathrm{kg}$ of raw ham) than in the standard pilesalting ( $\pm 1 \mathrm{~kg}$ of $\mathrm{NaCl} / \mathrm{kg}$ of raw ham) (Garcia-Perez et al., 2019). The post-salting stage lasted for 90 days, a longer time compared to the 50 days of the standard stage (Barat et al., 2005), in order to assure microbiological safety. During drying-maturation (approximately 400 days), some of the hams were wrapped twice, for 30 days, trying to induce high proteolysis levels. This manufacturing strategy mainly pursued separating the effect of the salt on the pastiness appearance and obtaining similar ranges of salt content for each pastiness group.

\subsection{Ultrasonic analysis}

Ten ultrasonic measurements were taken in the cushion zone of the whole ham. For each measurement, 10 ultrasonic signals were averaged. Likewise, the hams were measured in 7 different moments of the manufacturing: raw $\left(\mathrm{t}_{0}\right)$, salted ( $\left.\mathrm{t}_{\mathrm{s}}\right)$ and post-salted ham (90 days, $\left.\mathrm{t}_{\mathrm{ps}}\right), 3$ different moments during the drying-maturation stage (after $77\left(t_{d 1}\right), 134\left(t_{d 2}\right)$ and $231\left(t_{d}\right)$ days of drying) and at the end of the manufacturing (414 days of drying, $\mathrm{t}_{\mathrm{f}}$ ).

The ultrasonic equipment used to characterize the appearance of pastiness in the hams was designed and built by the ASPA research group of the Universitat Politècnica de València. The equipment was described in detail by Contreras et al. (2020). In brief, a pair of aligned narrow-band piezoelectric transducers (1 MHz, 1" diameter, A314S model, Panametrics, Waltham, MA, USA) was used: the emitter transducer attached to the edge of a rod slide electric actuator (LEY 16RB model, SMC, Tokyo, Japan) and the receiver transducer embedded in the 
base of the measurement platform. The ham was located in between both transducers and the actuator placed the emitter transducer on the surface of the ham and measured the ham thickness. In order to provide an appropriate sample-transducer coupling and to avoid excessive sample deformation, some water droplets were used as coupling material and the pushing force of the actuator was regulated depending on the manufacturing stage as follows: for raw and salted hams, the pushing force was $7.4 \mathrm{~N}$ while for the post-salted and dried-cured hams, $22.1 \mathrm{~N}$ were used. Once the transducers were positioned on the ham, the pulser-receiver (5058 PR model, Panametrics, Waltham, MA, USA) working in through-transmission mode, supplied a spike pulse to the emitter transducer that transformed the energy into a vibration that crossed the ham and arrived to the receiver transducer, which converted the mechanical energy into an electric signal. Subsequently, the electrical signal was filtered and conditioned by the pulserreceiver, digitized by an oscilloscope (USB-5133 model, National Instruments, Austin, USA) and sent back to a computer for its analysis.

For the calculation of the ultrasonic velocity, the time of flight of the ultrasonic signal was computed by using the energy threshold method (upper and lower thresholds 0.1 and -0.1 $\mathrm{V}$, respectively) considering the system delay $(0.7895 \mu \mathrm{s})$ as described by Garcia-Perez et al. (2019). Thus, the ultrasonic velocity was computed as the ratio between the sample thickness and the time of flight.

\subsection{Sensory texture analysis}

Once the manufacturing was finished, the hams were sliced $(1.5 \mathrm{~mm})$ and a threemember expert panel, trained following the American Society for Testing and Materials standards (ASTM STP 758, 1981), performed the sensory analysis of pastiness texture on the Biceps femoris $(\mathrm{BF})$ muscle, for being the innermost muscle and the most prone to develop pastiness. The dry-cured ham pastiness level was ranked from score 0 (absence) to 6 (maximum intensity) and the average score of the three experts was set as the pastiness level of the ham. Finally, according to the intensity of the textural defect, dry-cured hams were classified into three different groups: no pastiness (pastiness level<1), medium pastiness (pastiness level between 1 and 2.5) and high pastiness (pastiness level>2.5).

\subsection{Chemical analysis}

The salt content was also analyzed at the end of the manufacturing in BF muscle following standard methods (ISO1841-2, 1996). For that purpose, a potentiometric titrator 785 DMP Titrino (Metrohm AG, Herisau, Switzerland) was used. The salt content was expressed as a percentage on a wet basis (w.b.). 


\subsection{Statistical analysis}

Simple regression was used to relate the ultrasonic velocity at the end of the manufacturing and the salt content of the hams. Furthermore, a discriminant analysis was performed to classify the samples into high, medium and no pastiness levels according to the ultrasonic velocity measured during the ham manufacturing. Finally, a one-way analysis of variance (ANOVA) was conducted to study the differences of the ultrasonic velocity at the end of the manufacturing according to the pastiness level of the dry-cured ham. All the statistical analyses were carried out using Statgraphics Centurion XVI (Statpoint Technologies Inc., Warrenton, VA, USA).

\section{Results and discussion}

\subsection{Ultrasonic velocity during manufacturing}

Figure 1 shows the evolution of the ultrasonic velocity during dry-cured ham manufacturing, where each experimental point corresponds to the average of 200 hams. An increase in the ultrasonic velocity was observed during the manufacturing process. Points ' $r$ ' and 's' make reference to the ultrasonic velocity on the raw and salted hams, respectively (1536 and $1557 \mathrm{~m} / \mathrm{s}$, respectively). The slope obtained $(1.62 \mathrm{~m} / \mathrm{s}$ per day) between these two points was the highest found during the manufacturing since in few days, the velocity increased considerably. This fact was ascribed to the salt gain, since the ultrasonic velocity is faster when traveling in solids than in liquids (Benedito et al., 2000). Table 1 shows for the different salting times, the average variation of the ultrasonic velocity after salting and the average salt content of the hams at the end of the manufacturing process. It was observed that the longer the salting time, the higher the ultrasonic velocity variation at the end of the salting. Likewise, the average final salt content of the hams was higher in the hams salted for a longer period of time.Thus, as an example, the velocity variation of hams salted 4 and 11 days was 12.4 and $30.3 \mathrm{~m} / \mathrm{s}$, respectively, while their final salt content was 3.8 and 5.6 (\% w.b.), respectively. Previous literature already reported the increase in the ultrasonic velocity caused by ham salting (GarciaPerez et al., 2019). Higher variations on the ultrasonic velocity after salting were identified by de Prados et al. (2016), who found 25.3 and $47.3 \mathrm{~m} / \mathrm{s}$ of velocity variation for hams salted 4 and 11 days, respectively. These differences could be due to different process variables such as the size of the hams or the amount of salt used (de Prados et al., 2017). Between the end of salting (s, Figure 1) and the end of post-salting stage (ps, Figure 1), the average velocity also increased (from 1557 to $1587 \mathrm{~m} / \mathrm{s}$ ); however, the rise was smaller than in the salting stage since in the post-salting only the redistribution of salt inside the ham and a slight loss of water takes place (Grau et al., 2008). Thus, the slope obtained was $0.33 \mathrm{~m} / \mathrm{s}$ per day. From the post-salting to the first 77 days of drying-maturation (1587 and $1642 \mathrm{~m} / \mathrm{s}$, respectively), the velocity increase 
reached a slope of $0.71 \mathrm{~m} / \mathrm{s}$ per day, which was a larger increase compared to the rest of the manufacturing stages. This increase could be explained by considering drying of hams occurred in the falling rate drying period, thus, the longer the drying time the smaller the drying rate (Grau et al., 2011). As the drying-maturation period progressed, the velocity increase rate decreased, displaying an asymptotic trend (Figure 1), as the ham slowly reaches the equilibrium. Thus, the slopes between consecutive points during the drying-maturation progressively diminished (from $0.35 \mathrm{~m} / \mathrm{s}$ per day, corresponding to the period between $\mathrm{d} 1$ and $\mathrm{d} 2$ points, to $0.27 \mathrm{~m} / \mathrm{s}$ per day between $\mathrm{d} 2$ and $\mathrm{d} 3$ points and finally, to $0.14 \mathrm{~m} / \mathrm{s}$ per day between $\mathrm{d} 3$ and the final manufacturing points).

Table 1. Salting days, average ultrasonic velocity variation $(\Delta V)$ after the salting stage and average ham salt content at the end of the manufacturing.

\begin{tabular}{ccc}
\hline Salting days & $\boldsymbol{\Delta} \mathbf{V}$ after salting $(\mathbf{m} / \mathbf{s})$ & Ham final salt content $(\boldsymbol{\%} \mathbf{w . b})$. \\
\hline 4 & $13.2 \pm 5.8$ & $3.8 \pm 0.4$ \\
6 & $18.5 \pm 6.2$ & $4.4 \pm 0.4$ \\
8 & $24.6 \pm 3.8$ & $4.9 \pm 0.4$ \\
11 & $33.6 \pm 5.3$ & $5.6 \pm 0.5$ \\
\hline
\end{tabular}

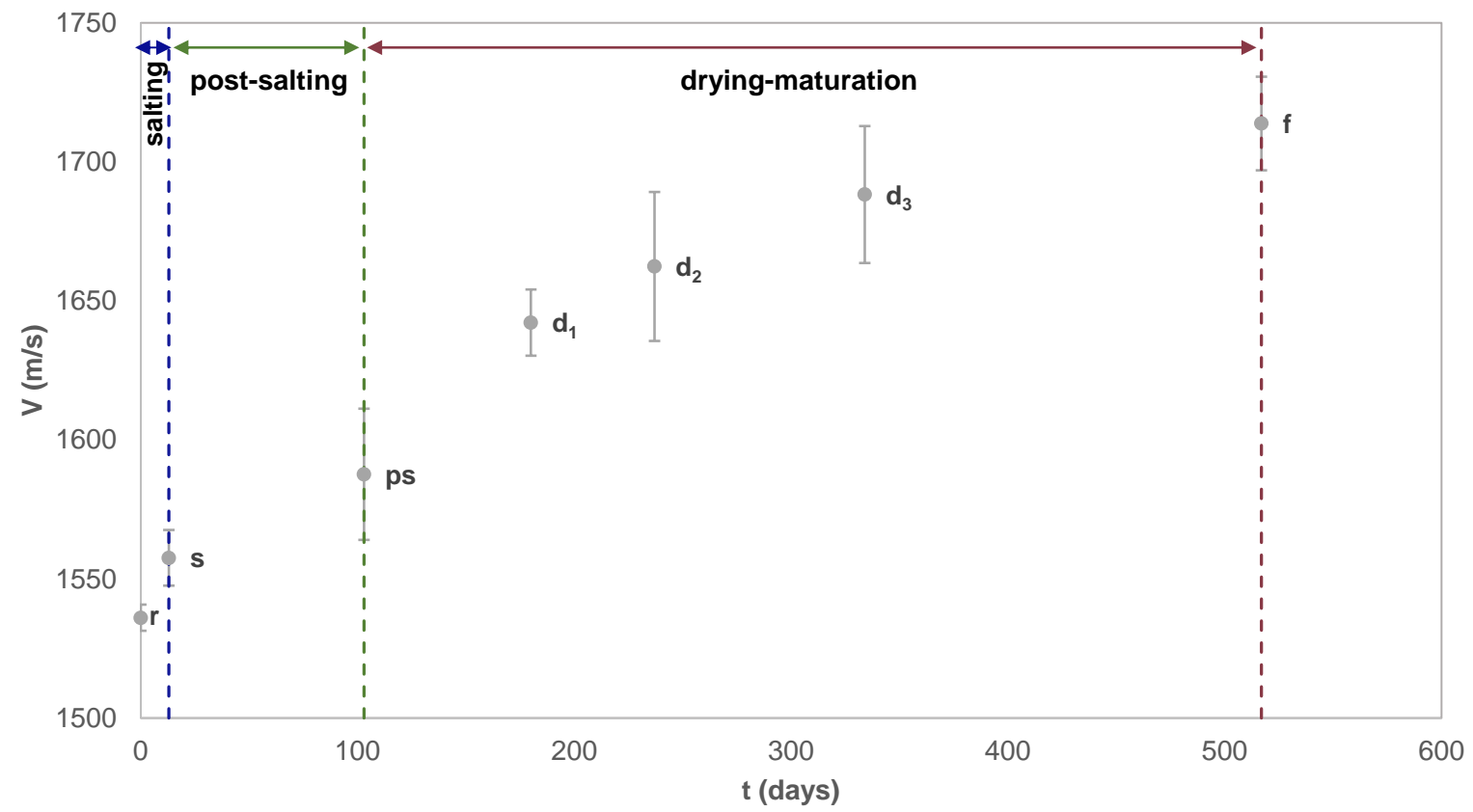

Figure 1. Evolution of the average ultrasonic velocity during ham manufacturing. Letters next to the measuring points indicate the measuring moment: raw ham (r), salted ham (s), post-salted ham (90 days, ps), 3 different times during the drying-maturation stage (after $77\left(d_{1}\right), 134\left(d_{2}\right)$ and 231 (d) days of drying) and at the end of the manufacturing (414 days of drying, $f$ ). 


\subsection{Relationship between the salt content and the ultrasonic velocity}

Figure 2 shows the relationship between the ultrasonic velocity and the salt content of the hams measured both at the end of the manufacturing. The relationship observed was statistically significant $(\mathrm{p}<0.05)$, showing a moderate relationship between both variables $(\mathrm{r}=0.58)$. Thus, the higher the salt content, the higher the ultrasonic velocity. Previous literature has also shown the influence of the salt content on the ultrasonic velocity. Diverse meat products have been tested by ultrasound in order to non-destructively determine its composition. In this sense, de Prados et al. (2015b) reported an increase in the ultrasonic velocity as the salt content of brined raw Biceps femoris and Longissimus dorsi pork muscles increased. Likewise, de Prados et al. (2017), demonstrated that the increase in the salt content of raw pork loin had a considerable influence on the rise of the ultrasonic velocity. Focusing on ham, the ultrasonic velocity has been satisfactorily related with the salt content after whole ham salting (de Prados et al., 2016, 2017; Garcia-Perez et al., 2019). As regards dry-cured ham, Fulladosa et al. (2015) also reported that an increase of salt content gave rise to higher ultrasonic velocities. However, despite the relationship obtained between salt and ultrasonic velocity in the present study, the variability found could be ascribed to the complex sample analyzed. Thus, in addition to the salt content, the ultrasonic velocity could be influenced by the moisture content and type and fat content of the ham (Corona et al., 2014; de Prados et al., 2015a; Niñoles et al., 2007). Furthermore, during the manufacturing process, protein and lipid reactions take place that could provoke changes in the mechanical properties of the ham and hence in the ultrasonic velocity (Niñoles et al., 2008).

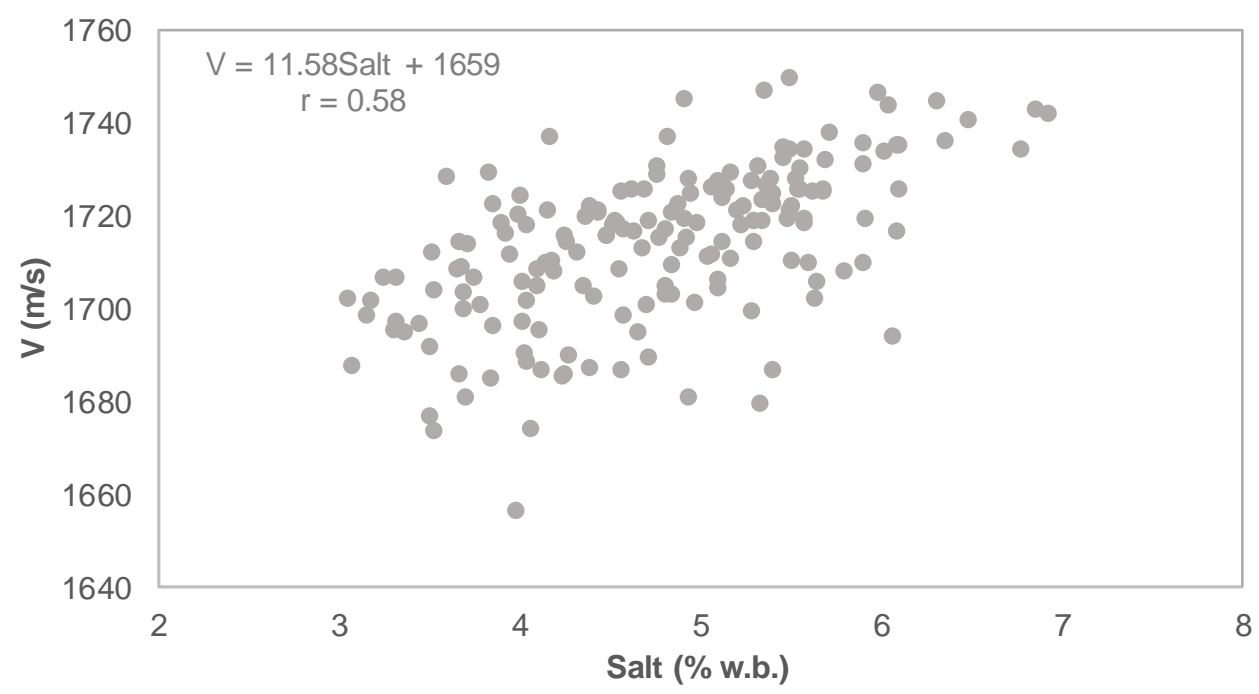

Figure 2. Relationship between the ultrasonic velocity and the salt content at the end of the ham manufacturing. 


\subsection{Influence of pastiness on the ultrasonic velocity}

Figure 3 shows the evolution of the ultrasonic velocity during the ham manufacturing according to its final pastiness level. For the different measuring times, the ultrasonic velocity was similar regardless the pastiness level of the ham. In this sense, the discriminant analysis performed considering the ultrasonic velocity in the different stages of the process was only able to classify correctly the $43.4 \%$ of the hams, according to its pastiness level. Lastly, the average ultrasonic velocity at the end of the manufacturing process for high pasty samples was slightly lower $(1712 \mathrm{~m} / \mathrm{s})$ than for medium and no-pasty samples $(1715$ and $1713 \mathrm{~m} / \mathrm{s}$, respectively). Notwithstanding, the one-way ANOVA performed did not find statistically significant differences $(p>0.05)$ on the average ultrasonic velocity depending on the ham pastiness level (Figure 4). This might be attributed to the fact that the ultrasonic velocity is largely affected by the salt content and other compositional and textural properties (Garcia-Perez et al., 2019), and for this reason, the differences introduce into the velocity due to the defect of pastiness could be masked. Moreover, it has to be highlighted that the ultrasonic velocity was measured in through-transmission mode in the cushion part of the ham, which includes not only the Biceps femoris, in which the pastiness was sensory evaluated, but also other muscles and intramuscular fat and backfat. This also affects the relationship between both variables and constitutes a fact to be analyzed in further works.

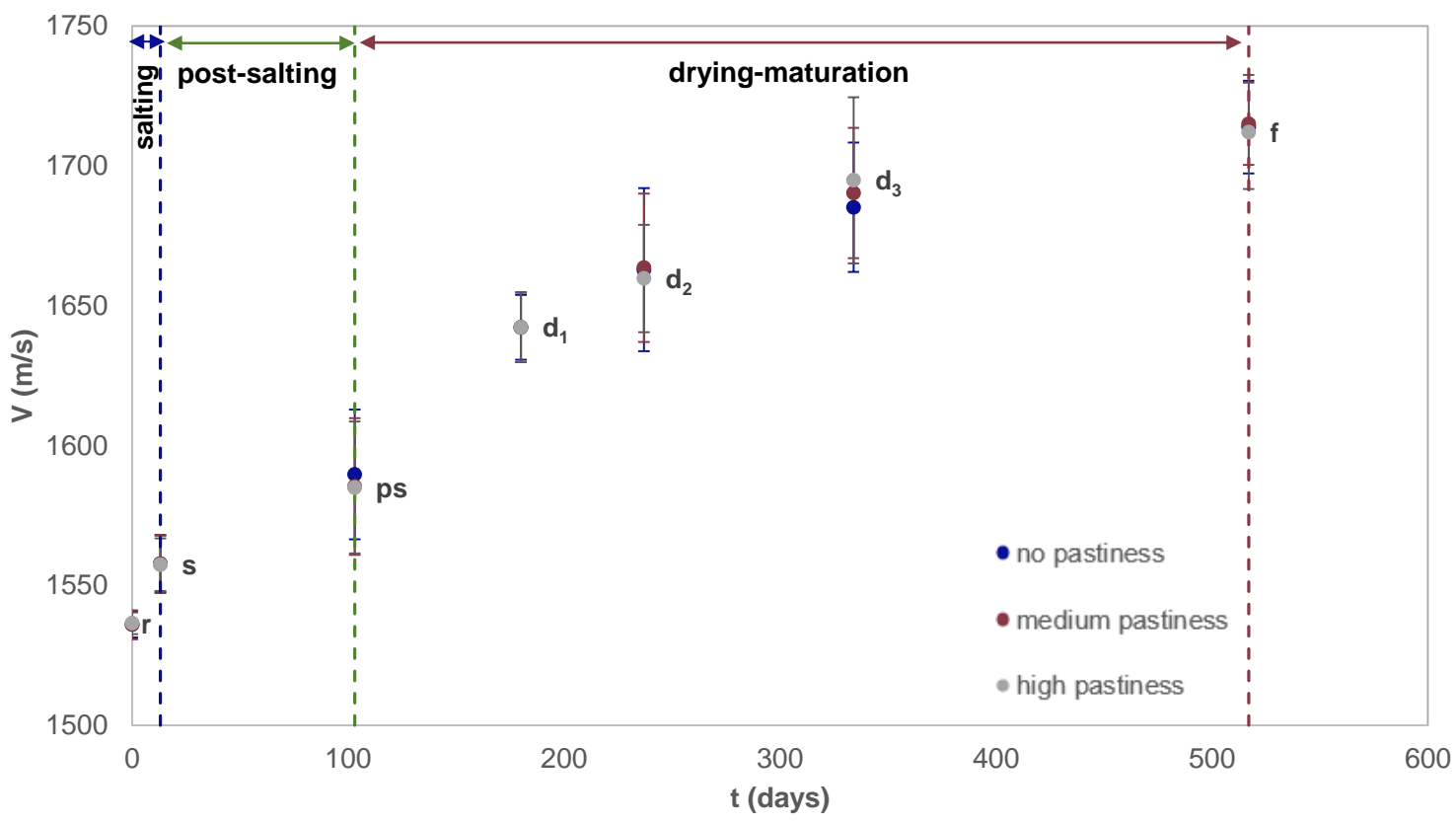

Figure 3. Evolution of the average ultrasonic velocity during ham manufacturing according to its pastiness level. 


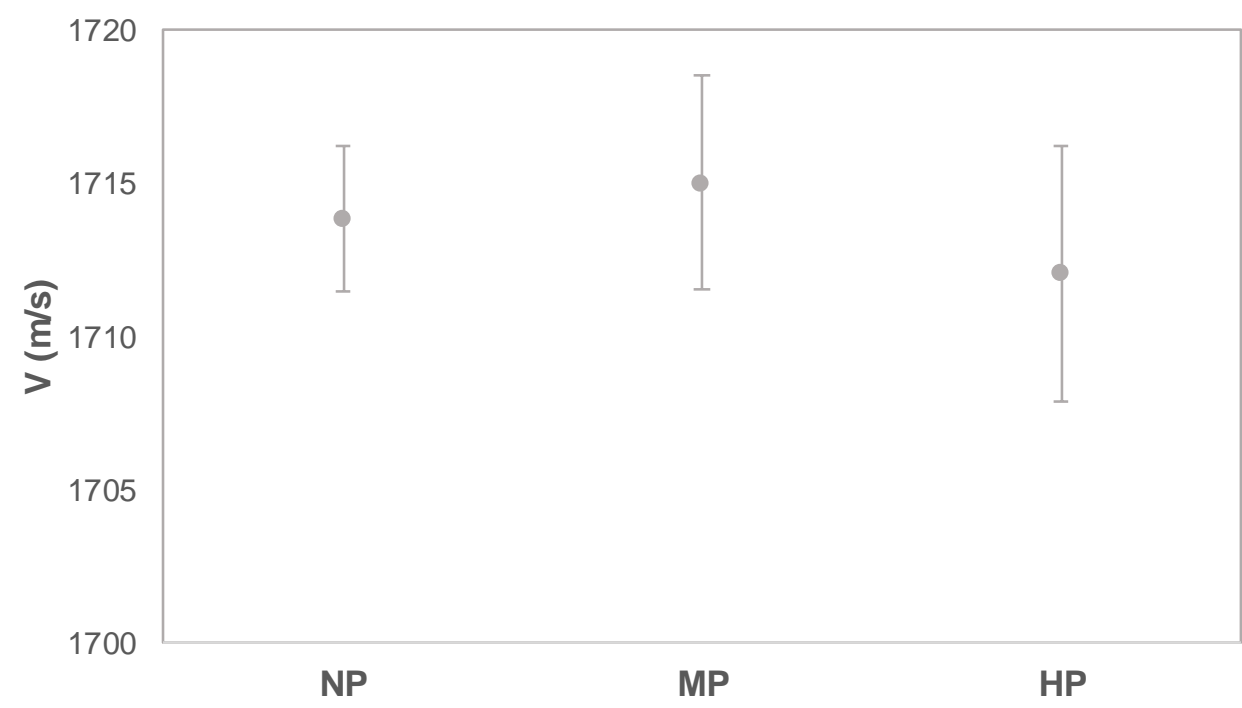

Figure 4. Average ultrasonic velocity of non-pasty (NP), medium (MP) and high pasty (HP) hams at the end of the manufacturing.

\section{Conclusions}

From the experimental results, it could be concluded that the ultrasonic velocity is a feasible parameter to non-destructively monitor the salt content changes during the manufacturing process of dry-cured ham. Notwithstanding, the ultrasonic velocity was not an appropriate parameter to identify the appearance of ham pastiness during manufacturing neither to distinguish between dry-cured hams with different levels of pastiness at the end of the process. In this respect, other ultrasonic parameters, such as the ultrasonic attenuation, should be considered, although its measurement in whole hams involves a great technological challenge.

\section{Acknowledgements}

The authors acknowledge financial support from the "Spanish Ministerio de Economía y Competitividad (MINECO), Instituto Nacional de Investigación y Tecnología Agraria y Alimentaria (INIA)" in Spain, European Regional Development Fund (ERDF 2014-2020) (Project RTA2013-00030-C03-02) and PhD grant of M. Contreras from Universitat Politècnica de València. 


\section{References}

ASTM STP 758. (1981). American Society for Testing and Materials. Guidelines for the selection and training of sensory panel members.

Bañón, S., Gil, M. D., \& Garrido, M. D. (2003). The effects of castration on the eating quality of dry-cured ham. Meat Science, 65, 1031-1037.

Barat, J. M., Grau, R., Ibáñez, J. B., \& Fito, P. (2005). Post-salting studies in Spanish cured ham manufacturing. Time reduction by using brine thawing-salting. Meat Science, 69, 201208.

Barat, J. M., Grau, R., Pagán-Moreno, M. J., \& Fito, P. (2004). Replacement of pile salting by simultaneous brine thawing-salting in Spanish cured ham manufacturing. Meat Science, $66,603-608$.

Benedito, J., Carcel, J. A., Sanjuan, N., \& Mulet, A. (2000). Use of ultrasound to assess Cheddar cheese characteristics. Ultrasonics, 38, 727-730.

Contreras, M., Benedito, J., Quiles, A., Lorenzo, J. M., Fulladosa, E., Gou, P., \& Garcia-Perez, J. V. (2020). Assessing the textural defect of pastiness in dry-cured pork ham using chemical, microstructural, textural and ultrasonic analyses. Journal of Food Engineering, $265,109690$.

Corona, E., García-Pérez, J. V., Mulet, A., \& Benedito, J. (2013). Ultrasonic assessment of textural changes in vacuum packaged sliced Iberian ham induced by high pressure treatment or cold storage. Meat Science, 95, 389-395.

Corona, E., García-Pérez, J. V., Santacatalina, J. V., Ventanas, S., \& Benedito, J. (2014). Ultrasonic characterization of pork fat crystallization during cold storage. Journal of Food Science, 79.

de Prados, M., Fulladosa, E., Gou, P., Muñoz, I., Garcia-Perez, J. V., \& Benedito, J. (2015a). Non-destructive determination of fat content in green hams using ultrasound and X-rays. Meat Science, 104, 37-43.

de Prados, M., García-Pérez, J. V., \& Benedito, J. (2015b). Non-destructive salt content prediction in brined pork meat using ultrasound technology. Journal of Food Engineering, $154,39-48$.

de Prados, M., Garcia-Perez, J. V., \& Benedito, J. (2016). Ultrasonic characterization and online monitoring of pork meat dry salting process. Food Control, 60, 646-655.

de Prados, M., Garcia-Perez, J. V., \& Benedito, J. (2017). Non-invasive ultrasonic technology for continuous monitoring of pork loin and ham dry salting. Meat Science, 128, 8-14.

Fulladosa, E., Austrich, A., Muñoz, I., Guerrero, L., Benedito, J., Lorenzo, J. M., \& Gou, P. 
(2018). Texture characterization of dry-cured ham using multi energy X-ray analysis. Food Control, 89, 46-53.

Fulladosa, E., de Prados, M., García-Perez, J. V., Benedito, J., Muñoz, I., Arnau, J., \& Gou, P. (2015). X-ray absorptiometry and ultrasound technologies for non-destructive compositional analysis of dry-cured ham. Journal of Food Engineering, 155, 62-68.

Fulladosa, E., Rubio-Celorio, M., Skytte, J. L., Muñoz, I., \& Picouet, P. (2017). Laser-light backscattering response to water content and proteolysis in dry-cured ham. Food Control, $77,235-242$.

Garcia-Perez, J. V., de Prados, M., Martinez, G., Gomez Alvarez-Arenas, T. E., \& Benedito, J. (2019). Ultrasonic online monitoring of the ham salting process. Methods for signal analysis: Time of flight calculation. Journal of Food Engineering, 263, 87-95.

García-Rey, R. M., García-Olmo, J., De Pedro, E., Quiles-Zafra, R., \& Luque De Castro, M. D. (2005). Prediction of texture and colour of dry-cured ham by visible and near infrared spectroscopy using a fiber optic probe. Meat Science, 70, 357-363.

Gou, P., Guerrero, L., \& Arnau, J. (1995). Sex and crossbreed effects on the characteristics of dry-cured ham. Meat Science, 40, 21-31.

Grau, R., Albarracín, W., Pérez, M. T., Antequera, T., \& Barat, J. M. (2011). Use of simultaneous brine thawing/salting in dry-cured Iberian ham production. Journal of Food Engineering, 104, 316-321.

Grau, R., Albarracín, W., Toldrá, F., Antequera, T., \& Barat, J. M. (2008). Study of salting and post-salting stages of fresh and thawed Iberian hams. Meat Science, 79, 677-682.

Guerrero, L, Gou, P., \& Arnau, J. (1999). The influence of meat pH on mechanical and sensory textural properties of dry-cured ham. Meat Science, 52, 267-273.

Guerrero, L., Gobantes, I., Oliver, M. À., Arnau, J., Guàrdia, M. D., Elvira, J., Riu, P., Grèbol, N., \& Monfort, J. M. (2004). Green hams electrical impedance spectroscopy (EIS) measures and pastiness prediction of dry cured hams. Meat Science, 66, 289-294.

ISO1841-2. (1996). Meat and Meat Products. Determination of Chloried Content.

Martín, L., Córdoba, J. J., Antequera, T., Timón, M. L., \& Ventanas, J. (1998). Effects of salt and temperature on proteolysis during ripening of Iberian ham. Meat Science, 49, 145153.

Niñoles, L., Clemente, G., Ventanas, S., \& Benedito, J. (2007). Quality assessment of Iberian pigs through backfat ultrasound characterization and fatty acid composition. Meat Science, $76,102-111$.

Niñoles, L., Sanjuan, N., Ventanas, S., \& Benedito, J. (2008). Ultrasonic and sensory 
characterization of dry-cured ham fat from Iberian pigs with different genetics and feeding backgrounds. Meat Science, 80, 896-902.

Parolari, G. (1996). Review: Achievements ,needs and perspectives in dry-cured ham technology: the example of Parma ham. Food Science and Technology International, 6978.

Parolari, G., Virgili, R., \& Schivazappa, C. (1994). Relationship between cathepsin B activity and compositional parameters in dry-cured hams of normal and defective texture. Meat Science, $38,117-122$.

Rubio, M., Fullados, E., Claret, A., Guàrdia, M. D., \& Garcia-Gil, N. (2013). Detection of pastiness in dry-cured ham using dielectric time domain reflectometry. 59th International Congress of Meat Science and Technology.

Ruiz-Carrascal, J., Ventanas, J., Cava, R., Andrés, A. I., \& García, C. (2000). Texture and appearance of dry cured ham as affected by fat content and fatty acid composition. Food Research International, 33, 91-95.

Ruiz-Ramírez, J., Arnau, J., Serra, X., \& Gou, P. (2005). Relationship between water content, $\mathrm{NaCl}$ content, $\mathrm{pH}$ and texture parameters in dry-cured muscles. Meat Science, 70, 579587.

Ruiz-Ramírez, J., Arnau, J., Serra, X., \& Gou, P. (2006). Effect of pH24, NaCl content and proteolysis index on the relationship between water content and texture parameters in biceps femoris and semimembranosus muscles in dry-cured ham. Meat Science, 72, 185194. 


Meat Science - Under review

Ultrasonic characterization of composition and texture modifications in dry-cured pork ham during post-salting

Marina Contreras, Jose Benedito, Jose Vicente Garcia-Perez

Grupo de Análisis y Simulación de Procesos Agroalimentarios (ASPA). Departamento de Tecnología de Alimentos. Universitat Politècnica de València. Camí de Vera s/n, Valencia (46022), Spain. 



\title{
Ultrasonic characterization of composition and texture modifications in dry-cured pork ham during post-salting
}

\begin{abstract}
Post-salting plays a key-role in dry-cured ham manufacturing since it contributes to salt diffusion under refrigeration conditions, thus, adverse microbial and enzymatic risks during subsequent process stages are minimized. For the first time, in this work, the use of nondestructive ultrasound to monitor ham post-salting has been addressed. For that purpose, the ultrasonic velocity $(1 \mathrm{MHz})$ and the weight loss of hams were measured regularly for 8 weeks after salting. Additionally, for different post-salting times, internal salt and moisture content and hardness were measured at different locations from the ham surface. Experimental results reflected that the ultrasonic velocity increased as the ham weight decreased during post-salting $(26.1 \mathrm{~m} / \mathrm{s}$ per $\mathrm{kg})$, showing a satisfactory correlation between both variables $(\mathrm{r}=0.95)$. Ultrasonic velocity was also significantly $(\mathrm{p}<0.05)$ correlated with the internal modifications of salt and moisture content. However, ham hardness remained fairly constant during post-salting, which confirmed that characteristic textural changes occur mainly during the salting and dryingmaturation stages. Thus, ultrasonic velocity could be a reliable parameter to monitor not only overall modifications of ham weight but also internal compositional changes caused by salt and moisture migration during post-salting in a non-destructive way.
\end{abstract}

Keywords: dry-cured ham; post-salting; monitoring, ultrasound. 


\section{Introduction}

Dry-cured ham manufacturing encompasses three well differentiated stages: salting, postsalting and drying-maturation. In Spain, hams are mostly dry-salted with a mixture of common $(\mathrm{NaCl})$ and nitrifying salts for 1-1.5 days per kg of raw ham (Barat et al., 2004) at refrigeration temperature $\left(1-3{ }^{\circ} \mathrm{C}\right)$ and relative humidity $(\mathrm{RH})$ in the range $75-95 \%$. After the salting stage, the salt is mainly located close to the ham surface. Thus, during the post-salting stage $\left(3-4{ }^{\circ} \mathrm{C}\right.$ and 75 $80 \% \mathrm{RH})$, the diffusion of the salt towards the internal muscles of the ham takes place. The average length of this stage is around 50 days (Barat et al., 2004) but it is highly variable according to specific industrial protocols. Post-salting has an important role in stabilizing the ham for the following stages since a correct salt content and distribution in hams avoids the microorganism growth and an uncontrolled proteolytic enzyme activity (Grau et al., 2007).

New consumer trends focused on reducing the salt intake in the diet (Barretto et al., 2018) are influencing dry-cured ham processing, since industrial manufacturers are trying to reduce the salt concentration in the final product (Aliño et al., 2010). A low amount of salt absorbed during salting involves a necessary extension of the post-salting stage in order to reach a minimum salt concentration in the inner of the ham to assure microbial and enzymatic stability. Nevertheless, this strategy directly and negatively impacts on process productivity; thus, manufacturers drive their efforts to the shortening of post-salting. In order to speed-up post-salting, temperature could be slightly and gradually risen, which greatly may encourage the activity of the proteolytic enzymes if salt content does not reach a minimum inhibition value. Thus, both the salt reduction and the temperature increase could jointly cause an excessive enzymatic proteolysis of the muscle proteins leading to textural defects such as pastiness (Coll-Brasas et al., 2019). In this sense, the search of new strategies to control ham composition and texture during post-salting is relevant considering both the new consumer trends of low-salt products and the necessary high industrial productivity.

Master ham manufacturers have traditionally verified the progression of post-salting by punching a thin stick close to the bridging bone (ham central bone) searching the characteristic smell of cured meat and the absence of blood. Nowadays, no feasible alternatives to the traditional method are available for industrial purposes. Notwithstanding, different approaches have been tackled in order to find out the salt and water content distribution during dry-cured ham postsalting in a non-destructive way. Computed tomography (CT) has been tested for this purpose. Thus, Vestergaard et al. (2005) reported a satisfactory $(r=0.84)$ description of the salt amount and distribution in whole hams at the end of post-salting based on CT response. The same approach was used by Håseth et al. (2012) who claimed the goodness of the CT-based model, although a slight overestimation of the salt content at the end of drying was found. Likewise, Santos-Garcés et al., (2012) used CT scans and reported that the presence of fat hindered the estimation of salt and water content. Recently, Harkouss et al. (2018) developed predictive models from CT images 
to estimate not only salt and moisture content distribution but also water activity, proteolysis index and the ham weight loss, obtaining a good prediction for every parameter at the end of salting and post-salting. Nuclear magnetic resonance (NMR) imaging has also been used satisfactorily to monitor non-destructively compositional changes during post-salting (Fantazzini et al., 2009). Nevertheless, the in-line inspection of hams based on CT and NMR technologies is hindered at industrial level by the long acquisition times and its high cost (Antequera et al., 2007; Fantazzini et al., 2009). Electronic tongue systems have also been applied to monitor the salting and curing of dry-cured hams. In particular, hams salted with different salt formulations were successfully classified using a potentiometric electronic tongue system and complex neural network statistical analysis (Gil-Sánchez et al., 2015). As regards ham texture, to our knowledge no previous literature has analyzed the textural changes experimented during the post-salting stage.

Within the non-destructive technologies, ultrasound could be used as an alternative to assess the changes occurring during ham post-salting due to its moderate cost compared to CT or NMR. In addition, compared to these technologies that are based on the use of electromagnetic waves, ultrasound does not involve the use of ionizing radiations, which results in simpler equipment manipulation, lower safety risks and easier industry implementation to monitor industrial processes. Thus, an ultrasound system and technology adapted to industry requirements was used by Garcia-Perez et al. (2019) for the online monitoring of the ham dry-salting process, and the time of flight of the ultrasonic signal was well correlated $(r=0.93)$ with the salt gain. The time of flight of the ultrasonic signal was also used by de Prados et al. (2017) to correctly classify $90 \%$ of hams depending on their salt content (low/medium/high categories). Likewise, the ultrasonic velocity was a reliable parameter $(\mathrm{r}=0.87)$ to estimate the salt content of ham after drysalting (de Prados et al., 2016, 2017). Furthermore, the ultrasonic velocity was also successfully used to evaluate the textural changes in vacuum packaged sliced Iberian ham caused by both high pressure treatment and cold storage (Corona et al., 2013). In this context, the main objective of this study was to analyze the feasibility of non-destructive ultrasound technology to monitor compositional and textural changes during ham post-salting.

\section{Materials and methods}

\subsection{Raw material, salting and post-salting}

Green hams from Landrace-Large White and Danish Duroc pig breed crosses were purchased in a local market (Valencia, Spain). The average weight of the hams was $10.9 \pm 0.7 \mathrm{~kg}$. Hams were individually dry-salted by covering them with $10-12 \mathrm{~kg}$ of coarse salt $(\mathrm{NaCl}$ moisturized at $10 \% \mathrm{w} / \mathrm{w}$ ) during 1 day per $\mathrm{kg}$ of ham in a cold room at $3 \pm 1{ }^{\circ} \mathrm{C}$ and $80-85 \% \mathrm{RH}$. After salting, hams were rinsed in order to remove the surface salt. For the post-salting stage, hams were hung up in a cold room at $3 \pm 1{ }^{\circ} \mathrm{C}$ and $75-80 \% \mathrm{RH}$. In order to assess the evolution of 
the physicochemical properties of the ham, the length of the post-salting varied from 7 to 56 days. Thus, every 7 days of post-salting, one ham was destructively analyzed.

\subsection{Ultrasonic experimental set-up and signal analysis}

The experimental set-up used for the ultrasonic measurements has been previously described in detail by Contreras et al. (2020). Briefly, the ultrasonic equipment consists on a pair of confronted and well aligned transducers $(1 \mathrm{MHz}, 1$ ' diameter, A314S model, Panametrics, Waltham, MA, USA) between which the ham was placed. The receiver transducer was fixed on a flat surface and the emitter transducer was attached to an automatic rod-type electric actuator (LEY 16RB model, SMC, Tokyo, Japan). Thus, the emitter transducer was automatically moved towards the ham surface until a target force was achieved, which assured an appropriate coupling between the transducers and the ham surface. No coupling medium was used since the pressure applied and the superficial moisture ensured the proper coupling. The electric actuator also reported the position of the transducer $( \pm 0.01 \mathrm{~mm})$, which allowed estimating the ham thickness.

Ultrasonic measurements were taken in 9 different points of the ham cushion following a preset pattern, which is shown in Figure 2A. Ultrasonic analysis was performed in the raw ham, after the salting stage and during the post-salting stage at intervals of two days. As the ham became harder, different compression loads of the transducer over the product surface were applied depending on the processing stage to assure a good transducer-sample coupling. Thus, target forces of 13, 15, 18.5 and $26 \mathrm{~N}$ were applied for raw hams, salted hams and hams post-salted longer than 28 and 42 days, respectively. A management software was created in LabVIEW ${ }^{\mathrm{TM}}$ (National Instruments, Austin, Texas) for automation purposes, which controlled the location of the emitter transducer, digitization unit and PC for ultrasonic signal acquisition. Despite the ultrasonic measurement was carried out at room temperature $\left(21.5 \pm 0.8^{\circ} \mathrm{C}\right)$, the automation of all the system provided a short measurement time (around 3 min per ham), which avoided relevant fluctuations of the ham temperature that could influence on the ultrasonic measurement.

The ultrasonic velocity was computed as the ratio between the thickness of the ham and the time of flight. As already mentioned, the thickness was provided by the electric actuator used to couple the emitter transducer on the ham surface, while the time of flight was assessed using the energy threshold method (Garcia-Perez et al., 2019). As an example, Figure 1 shows the differences in the time of flight of two ultrasonic signals for the same ham and measurement point at two different stages of the post-salting ( 0 and 56 days). For every measuring point, 10 ultrasonic signals were acquired and averaged. Finally, for each ham, the ultrasonic velocity calculated in the 9 measuring points was averaged. In order to determine the ultrasonic velocity variations during salting and post-salting stages, the changes of the ultrasonic velocity between the salted and the raw ham (Eq. 1) and between the post-salted and the salted ham (Eq. 2) were calculated: 


$$
\begin{aligned}
& \Delta V_{s}=V_{s}-V_{0} \\
& \Delta V_{p s}=V_{p s}-V_{s}
\end{aligned}
$$

where $V_{o}, V_{s}$ and $V_{p s}$ are the ultrasonic velocity of the raw, salted and post-salted ham, respectively.

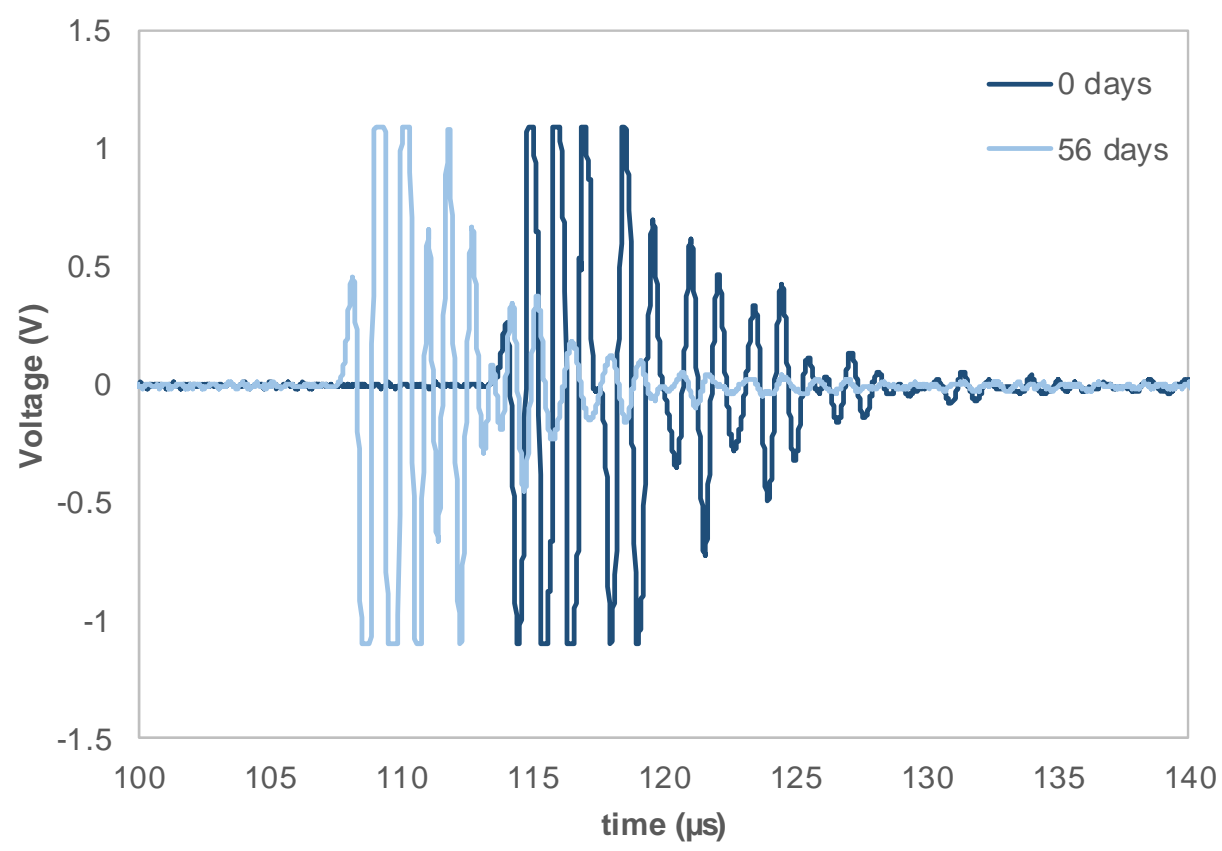

Figure 1. Ultrasonic signals for measuring point 7 (Figure $2 \mathrm{~A})$ at two different post-salting times (0 and 56 days).

\subsection{Physicochemical analyses}

Ham weight $( \pm 0.001 \mathrm{~kg})$ was recorded in the raw ham, after salting and every 2 days during post-salting. As in the case of the ultrasonic velocity changes, the determination of the ham weight loss variation during salting and post-salting stages was performed; thus, the change of the weight between the salted and the raw ham (Eq. 3) and between the post-salted and the salted ham (Eq. 4) were calculated:

$$
\begin{aligned}
& \Delta W_{s}=W_{s}-W_{0} \\
& \Delta W_{p s}=W_{p s}-W_{s}
\end{aligned}
$$

where $W_{o}, W_{s}$ and $W_{p s}$ are the weight of the raw, salted and post-salted ham, respectively.

In order to analyze the internal salt and moisture content distribution and hardness during post-salting, one ham was analyzed each 7 days. Thus, the cushion part of the ham, which includes the 9 measuring points for ultrasonic analysis, was separated and divided in 3 slices ( $\pm 3 \mathrm{~cm}$ thick) (Figure 2). Slice 1 included measuring points 1-2-3, slice 2: 4-5-6 and slice 3: 7-8-9. Afterwards, 
every slice was split in 3 parallelepiped-shaped samples $(3 \mathrm{~cm} \times 3 \mathrm{~cm} \times$ ham height) in order to separate the section corresponding to each measuring point. Thereby, 9 parallelepiped-shaped sections coinciding with each measuring point were obtained (Figure 2B). Finally, each parallelepiped was split into two parts: the external zone, corresponding to the Semimembranosus muscle and closer to the lean surface of the ham and the internal zone, corresponding to the Biceps femoris and Semitendinosus muscles and closer to the subcutaneous fat layer (Figure 2). The lean surface $( \pm 3 \mathrm{~mm})$ in which the majority of the salt is absorbed during salting and the subcutaneous fat of the ham were separated from the external and the internal parts of the paralepidids, respectively (Figure 2). Thus, the salt propagation from the lean surface to the external and internal zones was analyzed. The subcutaneous fat was removed in order to do not alter the moisture content of the internal zone. The physicochemical parameters to be described hereinafter were measured in triplicate per measuring point and ham zone at the end of post-salting and afterwards, the measurements were averaged for the whole ham.

Hardness was measured using a texturometer (TA-XT2, SMS, Godalming, UK) provided with a load cell of $50 \mathrm{~kg}$. A simple compression test was carried out at constant temperature $(4 \pm 1$ ${ }^{\circ} \mathrm{C}$ ) using a flat $10 \mathrm{~mm}$ diameter cylindrical aluminum probe (SMS P/IK). The samples were compressed to $25 \%$ of their original height perpendicular to the fiber bundle direction at a crosshead speed of $1 \mathrm{~mm} / \mathrm{s}$. In order to cover the maximum possible area, the simple compression test was performed 27 times per zone (external or internal), corresponding with the 3 replicates carried out in every of the 9 measuring points (Figure 2). The experimental data were recorded and processed with Exponent Lite 6.1.4.0 software (SMS, Godalming, UK). Thus, hardness (F) was computed from the force versus time profiles as the maximum force achieved during compression. After the textural analysis, salt and moisture content were determined.

In order to measure the salt content, $1 \mathrm{~g}$ of ground ham was homogenized with $80 \mathrm{~mL}$ of Milli-Q water using an ultraturrax (T25, IKA Labortechnik, Germany) at 9500 rpm during 5 min. The extract obtained was filtered and titrated with $\mathrm{AgNO}_{3} 0.1 \mathrm{~N}$ using a potentiometric titrator 785 DMP Titrino (Metrohm AG, Herisau, Switzerland) following the standard method (ISO1841$2,1996)$. The salt content was calculated from the $\mathrm{mL}$ of $\mathrm{AgNO}_{3}$ spent in the titration. The results were expressed as a percentage of $\mathrm{NaCl}$ on a wet basis (w.b., $\mathrm{kg}$ salt $/ \mathrm{kg}$ total matter).

Moisture content was determined following the standard AOAC method 950.46 (AOAC, 1997). Thus, $2 \mathrm{~g}$ of ground ham were introduced in an oven at $102^{\circ} \mathrm{C}$ until reaching a constant weight (24 h). The moisture content was expressed in wet basis (w.b., $\mathrm{kg}$ water/kg total matter). 
2A

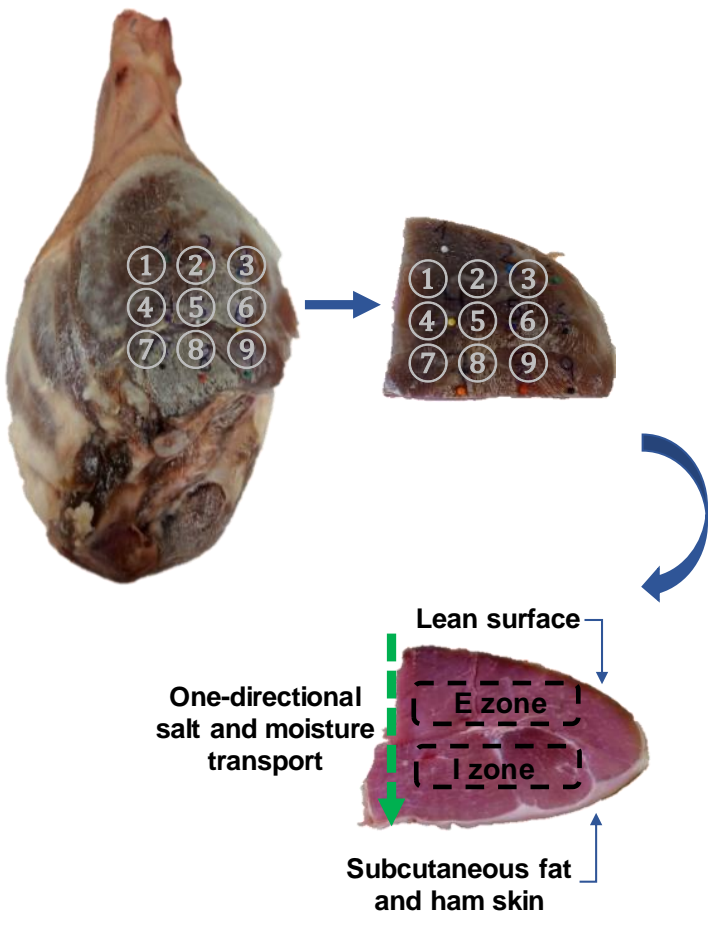

2B
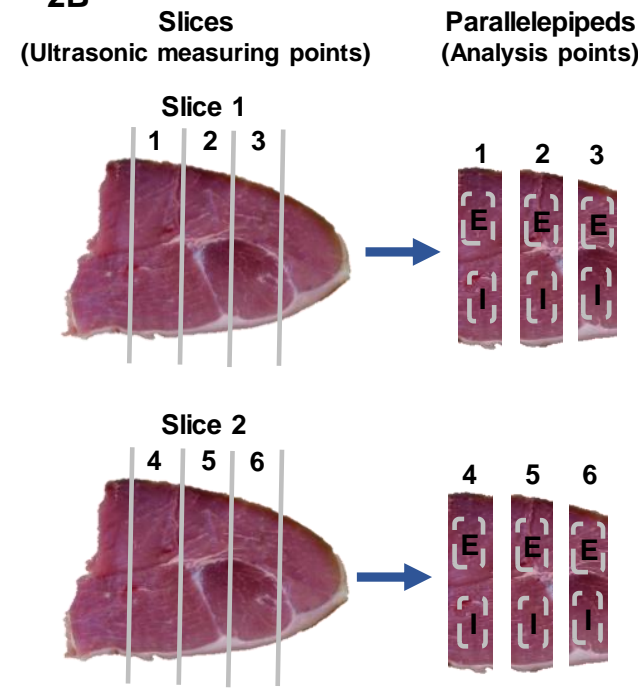

Slice 3

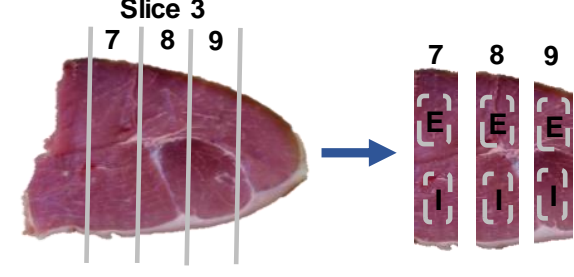

Figure 2. Location of measuring points of the ultrasonic velocity on the ham cushion and top and front view of the extracted section with indication of external (E) and internal (I) zones (2A). Slices and parallelepipeds obtained for textural and chemical analysis (2B).

\subsection{Statistical analysis}

In order to evaluate the statistical significance of the relationship between the ultrasonic velocity variation and the ham weight variation during the salting and post-salting stages, linear regressions were carried out. The post-salting time was categorized as early (from 7 to 14 days), intermediate (from 21 to 35 days) and final (from 42 to 56 days) in order to analyze whether salt and moisture content and hardness were significantly $(\mathrm{p}<0.05)$ changed during post-salting. Thereby, multi-factor analysis of variance (ANOVA) $(\mathrm{p}<0.05)$ was performed to identify significant $(\mathrm{p}<0.05)$ changes of the aforementioned variables for each post-salting period and ham zone (internal and external). In addition, linear regression was also used to stablish relationships between the changes of ultrasonic velocity and salt, moisture and hardness modifications. ANOVAs, least significant difference (LSD) intervals and the linear regressions were estimated using the statistical package Statgraphics Centurion XVI (Statpoint Technologies Inc., Warrenton, VA, USA) considering a significance level of 95\%. 


\section{Results and discussion}

\subsection{Change of ultrasonic velocity after salting}

The weight loss during salting for each ham was similar, ranging from 0.55 to $0.84 \mathrm{~kg}$, which represents a moderate decrease between 5.4 and $7.5 \%$ of the initial ham weight. Harkouss et al. (2018) studied the evolution on the ham weight during salting and post-salting by means of a multi-physical model from X-ray CT images of green hams. The model predicted a weight loss of approximately $3 \%$ during salting, a slightly lower value compared to the obtained in this study probably because the "numerical ham" model did not account properly the amount of liquid water that migrates to the ham surface during salting. However, the same authors (Harkouss et al., 2018) reported for Bayonne hams a weight loss of $4.5 \%$, a closer value to the results obtained in this study.

As for the variation of ultrasonic velocity, figures laid between 23.2 and $32.3 \mathrm{~m} / \mathrm{s}$. Higher ultrasonic velocity variations were found by de Prados et al. (2016) after ham salting during 11 days $(47.3 \pm 7.6 \mathrm{~m} / \mathrm{s})$. This fact could be ascribed to the different structure and composition of the hams in addition to the different pig breed used in both studies since hams from Large White breed were utilized by de Prados et al. (2016). Weight loss and velocity variation were correlated using a linear regression model (Figure 3) $(r=0.69)$. Thus, it was observed that the larger the weight variation (more negative figure), the higher the ultrasonic velocity variation. During salting, the salt gain and the weight loss, mainly associated to the water loss, leads to an increase in the solid fraction of the ham that provokes an increase in the ultrasonic velocity (de Prados et al., 2017), which has already been reported in different food products, such as reconstituted orange juice (Kuo et al., 2008), mango ripening (Valente et al., 2013), brined pork loin (de Prados et al., 2015) and dry-salted pork loin or ham (de Prados et al., 2016, 2017). Likewise, the increase of the ultrasound velocity might also be linked to textural modifications, particularly to the contraction and hardening of the meat myofibrils during salting as a consequence of the salt gain and moisture loss, leading to a larger elastic modulus (Garcia-Perez et al., 2019). 


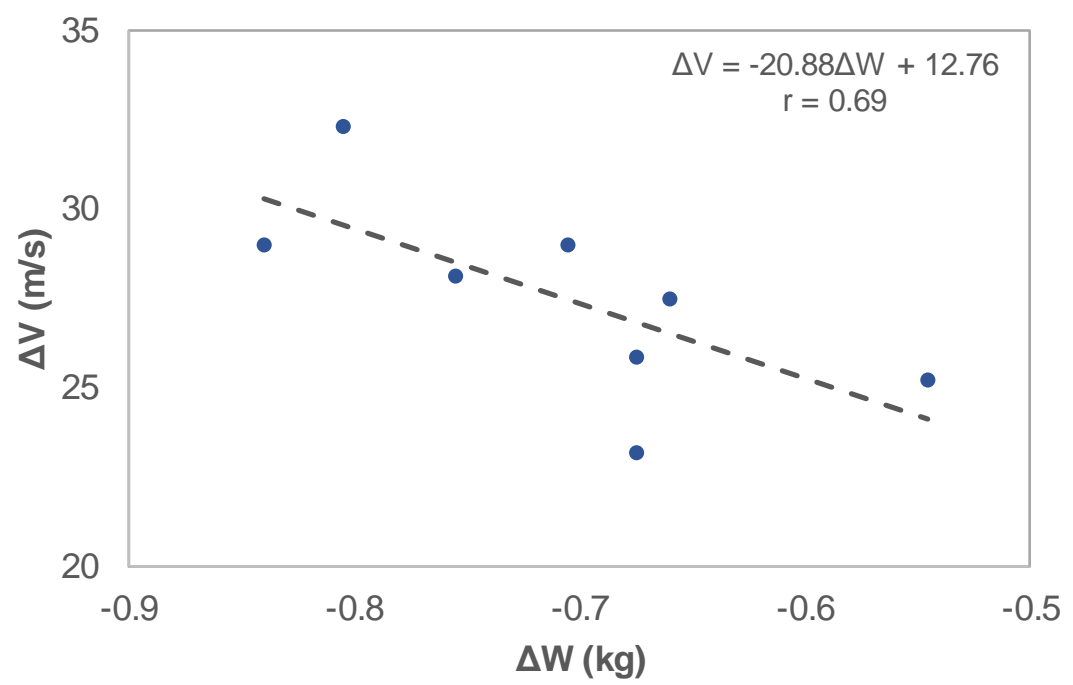

Figure 3. Relationship between weight $(\Delta W)$ and ultrasonic velocity $(\Delta V)$ variations during ham salting. Each experimental point corresponds to a different ham.

\subsection{Ultrasonic velocity evolution during post-salting}

Figure 4 shows the accumulated weight and ultrasonic velocity variation during 56 days of post-salting. As the post-salting progressed, the ham gradually lost weight due to the water loss; an average weight loss of $0.034 \mathrm{~kg}$ per day was observed, which represented a $0.35 \%$ of weight decrease. On the contrary, the ultrasonic velocity experimented an increase during postsalting at an average rate of $0.81 \mathrm{~m} / \mathrm{s}$ per day. This velocity evolution might be attributed mainly to the water loss (Benedito et al., 2000a), although the salt diffusion from the lean surface to the inner part of the ham could also contribute to the ultrasonic velocity increase (Grau et al., 2011) .

In Figure 5A, the final variation of weight and ultrasonic velocity during ham post-salting is shown for each ham analyzed. The ham post-salted for 7 days presented the lowest weight variation $(0.22 \mathrm{~kg})$ but as the post-salting progressed, the hams weight loss regularly increased due to the loss of water. For the longest post-salting time (56 days), the highest weight variation $(1.28 \mathrm{~kg})$ was experimented, which corresponded to a $12.3 \%$ total weight loss during post-salting. As previously mentioned, Harkouss et al. (2018) used a "numerical ham" model based on CT images of green hams to predict its weight loss during post-salting, finding out a slightly higher weight loss (14.5\% after 56 days of post-salting). The same authors (Harkouss et al., 2018) also reported a slightly greater experimental weight loss (17\% after 56 days of post-salting) on Bayonne hams. As for the ultrasonic velocity variation, it ranged from 3.7 (7 days) to $31.9 \mathrm{~m} / \mathrm{s}$ (56 days). To our knowledge, no previous studies have addressed the ultrasonic modifications in a dry-cured meat product during post-salting. 


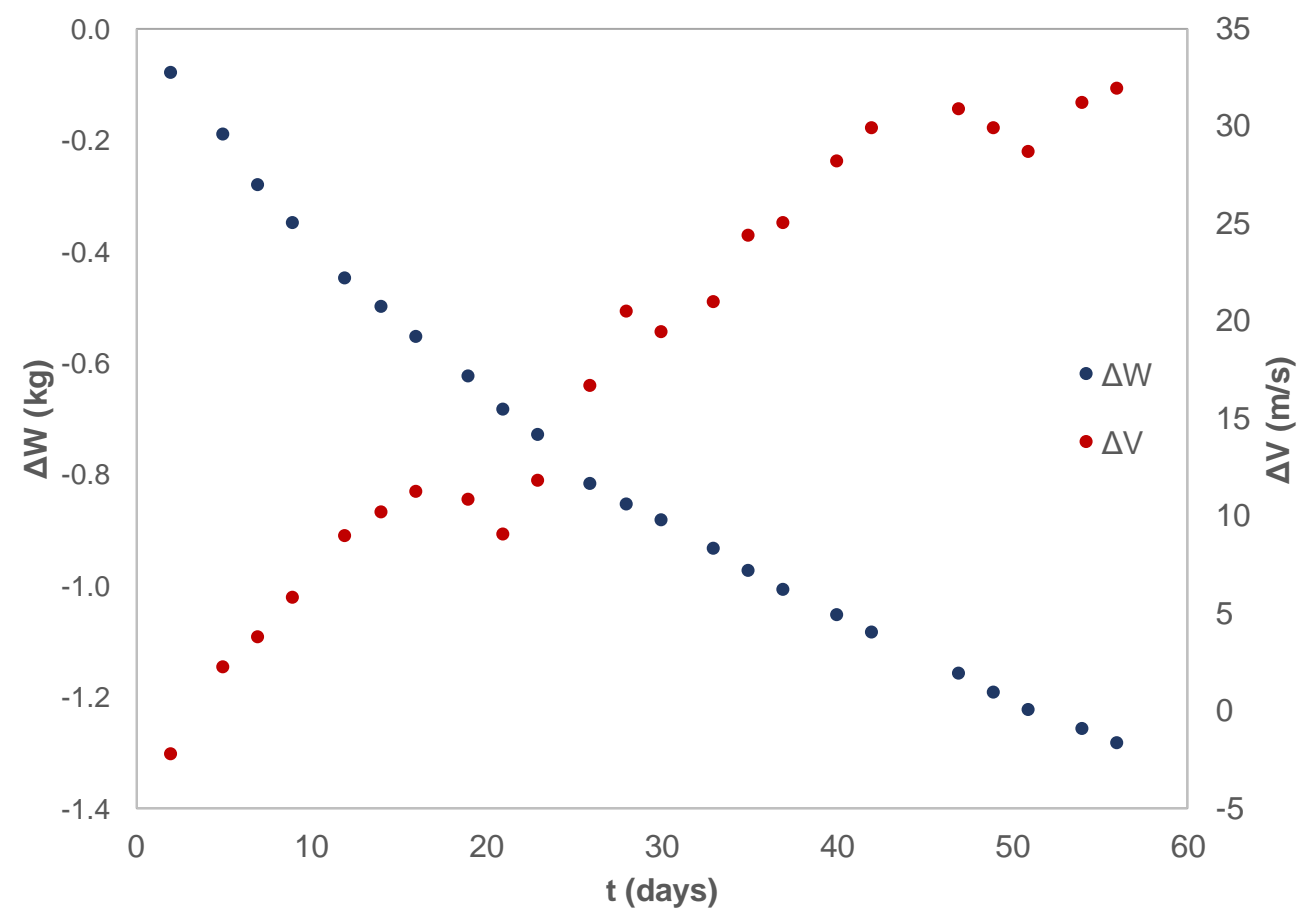

Figure 4. Accumulated weight $(\Delta W)$ and ultrasonic velocity $(\Delta V)$ variation during 56 days of ham post-salting.

A significant $(\mathrm{p}<0.05)$ linear correlation $(\mathrm{r}=0.95)$ between the ultrasonic velocity and weight variation during post-salting (Figure 5B) was found. If linear regressions depicted in Figures 3 and 5B are compared, it could be observed that a better correlation was found between $\Delta \mathrm{V}$ and $\Delta \mathrm{W}$ for post-salting than for salting. This could be explained by the difference in the range of weight loss at both steps, from 0.55 to $0.84 \mathrm{~kg}$ in salting and from 0.22 to $1.28 \mathrm{~kg}$ in post-salting. Furthermore, the post-salting has a simpler nature, since only a net flux of water leaving the ham takes place during this stage (salt is only redistributed), while during salting, a simultaneous water removal and salt gain occurs and hence the source of variability on the ultrasonic velocity variation is higher. Thus, this fact is reflected in the greater slope of Figure 3 $\left(-20.88 \mathrm{~kg} / \mathrm{m} \cdot \mathrm{s}^{-1}\right)$ compared to Figure 5B $\left(-26.10 \mathrm{~kg} / \mathrm{m} \cdot \mathrm{s}^{-1}\right)$, since for the same weight loss in both salting and post-salting, the salting stage has the additional salt gain and hence the greater variation on the velocity. 

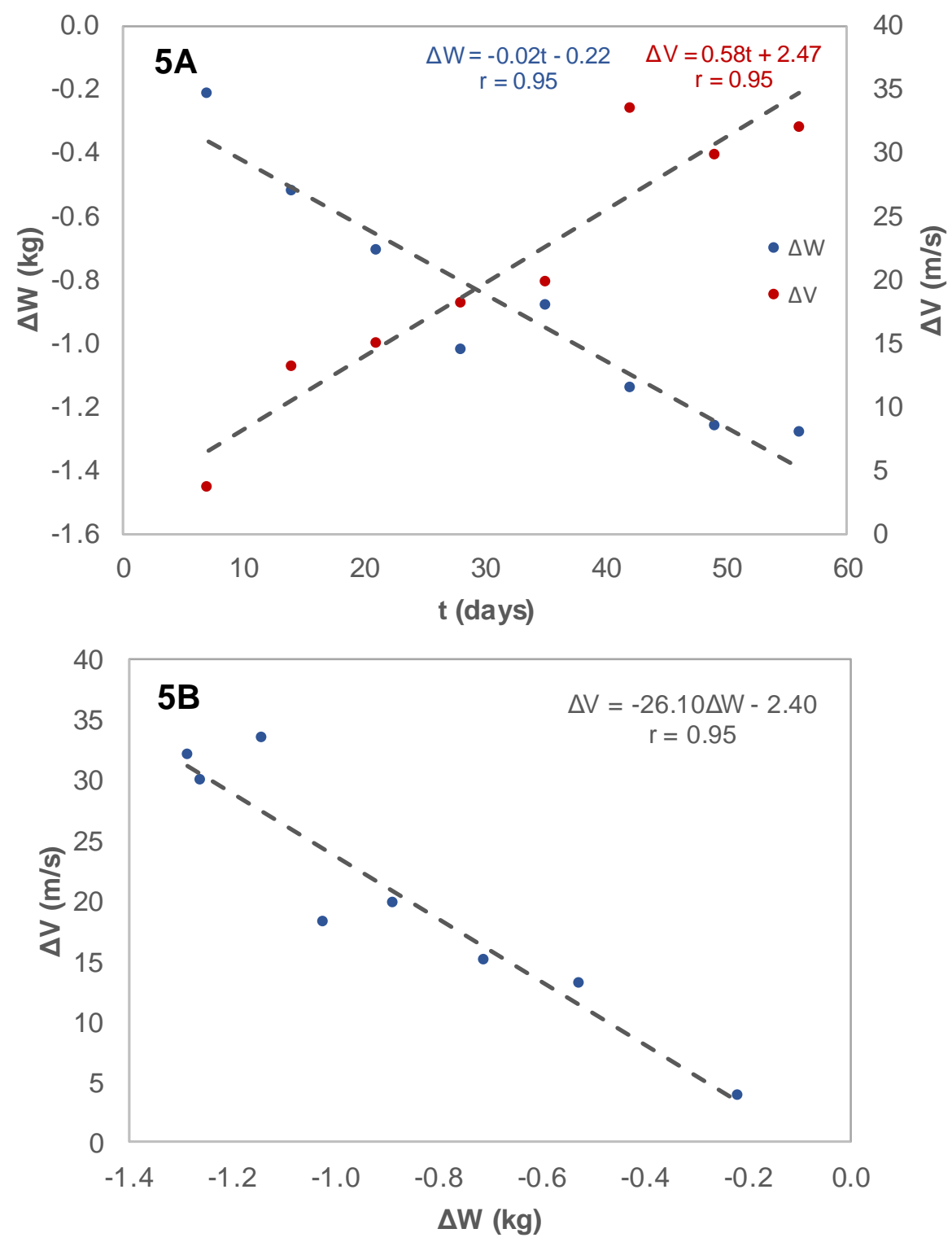

Figure 5. Final weight $(\Delta W)$ and ultrasonic velocity $(\Delta V)$ variation for hams post-salted from 7 to 56 days (5A) and relationship between both variables (5B). In both figures, each point corresponds to a different ham.

\subsection{Changes of ultrasonic velocity caused by modifications of ham composition}

Figures 6A and 6B illustrate the change of salt and moisture content at early, intermediate and final post-salting in both the internal and external ham zones. As expected, a trend of salt increase and moisture decrease was found for both zones, which is promoted by salt distribution from the ham lean surface to the internal zones of the ham and by the drying taking place during the post-salting. Differences between the groups of post-salting stage were not significant $(p>0.05)$ neither for the salt nor for the moisture content, which is explained by the high experimental variability ascribed to the heterogeneous nature of the ham. Despite this fact, linear 
relationships were found between the salt content of both zones and the post-salting time (Eq. 5 and 6 for the external zone and internal zone, respectively).

$$
\begin{aligned}
& \text { Salt }_{\text {external }}(\% w . b .)=0.02 \text { time }(\text { days })+2.33 \quad r=0.51 \\
& \text { Salt }_{\text {internal }}(\% w . b .)=0.013 \text { time }(\text { days })+0.905 \quad r=0.67
\end{aligned}
$$

The average salt content of the external and the internal zone of the hams at the early post-salting was 2.39 and $0.92 \%$ w.b., respectively, while at the final post-salting, the values were higher (3.13 and $1.47 \%$ w.b. for the external and internal zone, respectively) (Figure 6A). As for the differences between zones, it can be observed that the external part of the ham (E) always presented a significantly $(\mathrm{p}<0.05)$ higher concentration of salt than the internal zone (I). Thus, as an example, at the intermediate post-salting, the external zone of the ham presented an average salt content of $2.54 \%$ w.b. compared to the $1.03 \%$ w.b. of the internal zone (Figure 6A). The higher salt concentration in the external zone reflects that salt penetration occurs predominantly through the lean surface, since the fat and skin on the opposite surface prevent the salt penetration (Arnau et al., 2003). Thus, during post-salting, the salt diffusion is mainly one-directional (Figure 2).

The average moisture content for the longest post-salting time (56 days) was $66.4 \%$ w.b., which is in agreement with the value attained by Harkouss et al. (2018) for Bayonne hams after 56 post-salting days (average value of $67 \%$ w.b.) and also matched with the predicted value obtained by the same authors using a mathematical model from green hams CT images. As for the moisture content in the external and the internal ham zones along post-salting, the differences between them were not significant $(p>0.05)$ (Figure $6 B$ ). As in the case of the salt penetration during salting, drying mostly occurs through the opposite surface to the subcutaneous fat, thus, a lower moisture content could be expected in the external than in the internal zone. But, as the degree of moisture loss is moderate during post-salting, the initial moisture differences between ham muscles could mask the further change. Furthermore, the important driving force for water transport from the internal to the external zone due to the salt content difference (Figure 6A) could make that water transport between both zones matches the evaporation on the surface, which results in a similar moisture content during the post-salting stage. 

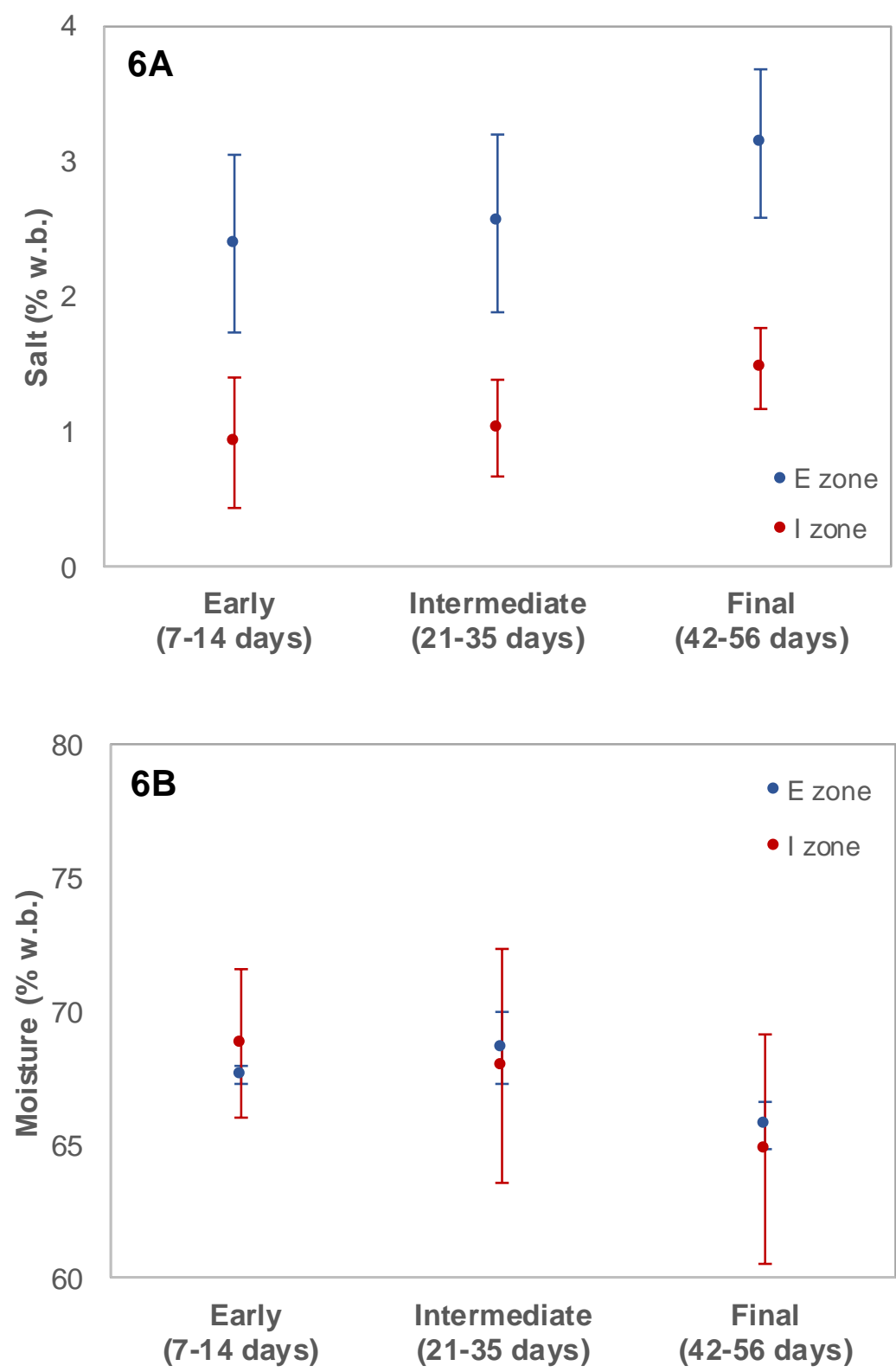

Figure 6. Evolution of salt (\% w.b.) (6A) and moisture content (6B) in the external (E) and internal (I) zones of the hams grouped depending on the post-salting time: hams post-salted 7 and 14 days (early post-salting), hams post-salted from 21 to 35 days (intermediate post-salting) and hams postsalted from 42 to 56 days (final post-salting). Error bars show LSD intervals (95\%).

When relating the final ultrasonic velocity of every ham with its salt content after postsalting (Figure 7A), it was observed that the higher the salt content, the higher the ultrasonic velocity, showing a significant $(\mathrm{p}<0.05)$ linear correlation $(\mathrm{r}=0.93)$. As previously mentioned, this could be linked to the fact that the velocity of ultrasound is faster in solids than in liquids (Benedito et al., 2000b), thus, an increase of the solid content leads to higher ultrasonic velocities. As for the moisture content, the correlation $(\mathrm{r}=0.86)$ with the ultrasonic velocity was also significant $(\mathrm{p}<0.05)$ (Figure 7B). Thus, the lower the moisture, the higher the ultrasonic velocity. 

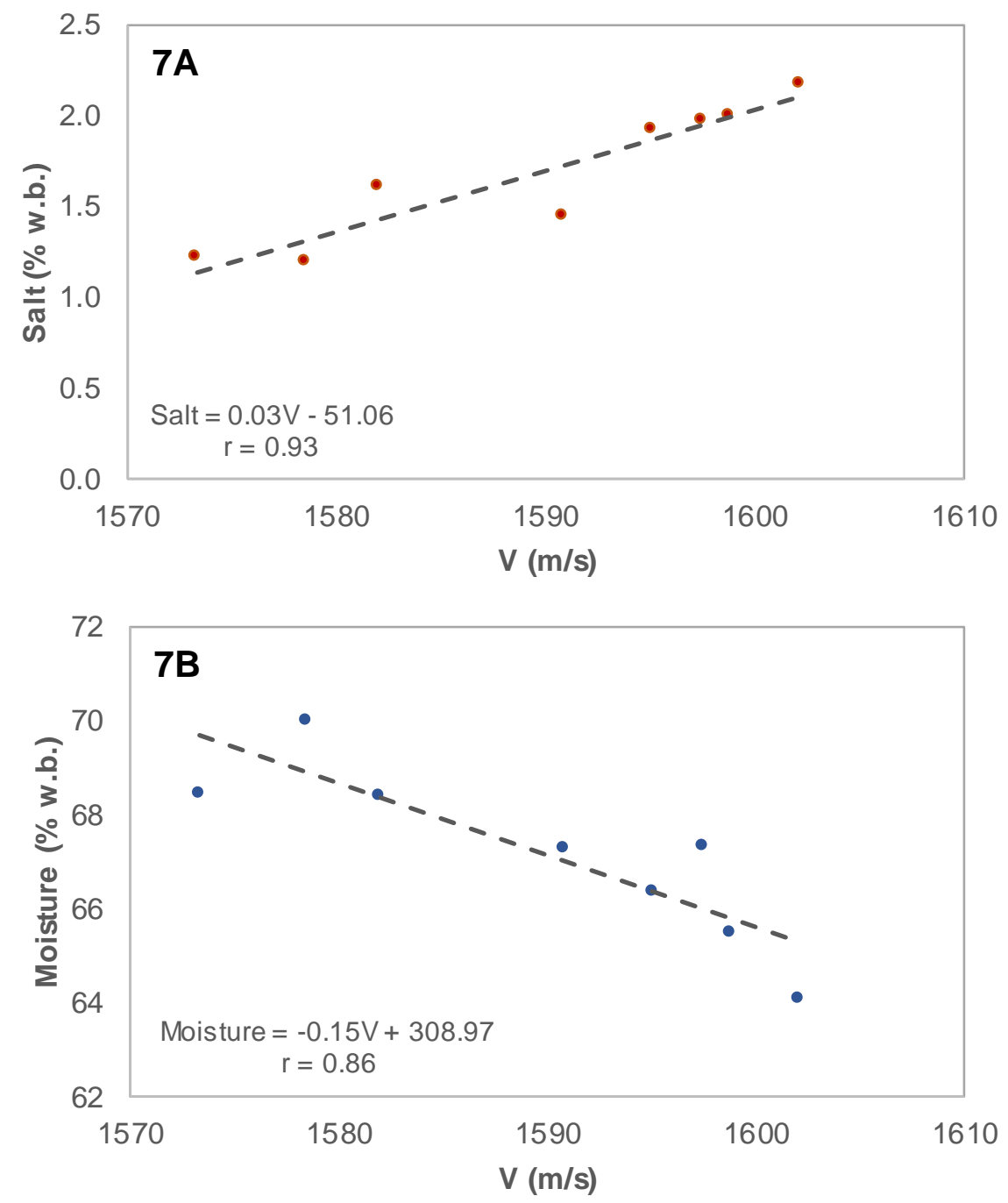

Figure 7. Relationship between salt (7A) and moisture content (7B) and ultrasonic velocity (V) during ham post-salting. In both graphs, each point corresponds to a different ham.

\subsection{Changes of ultrasonic velocity caused by modifications of ham texture}

Figure 8A shows the hardness of the hams at early, intermediate and final post-salting. For both the external (E) and the internal (I) ham zones, no increase in hardness was found as the post-salting proceeded, which indicates that during this stage, the potential textural modifications were undetectable by the instrumental test assayed. Thus, at early post-salting stage, the average ham hardness was 2.8 and $1.6 \mathrm{~N}$ for the external and internal zone, respectively. Similarly, the average ham hardness at the final post-salting was 3.2 and $1.4 \mathrm{~N}$ for the external and internal zone, respectively. However, it was observed that regardless the post-salting time, the external zone was always harder than the internal one. As an example, at the intermediate stage of the post-salting, the average hardness of the external zone of the ham was $2.1 \mathrm{~N}$ while for the internal zone was $1.3 \mathrm{~N}$. A higher salt content promotes protein denaturation causing a hardness increase (Arnau et al., 2003), which explains the harder structure of the external part. 

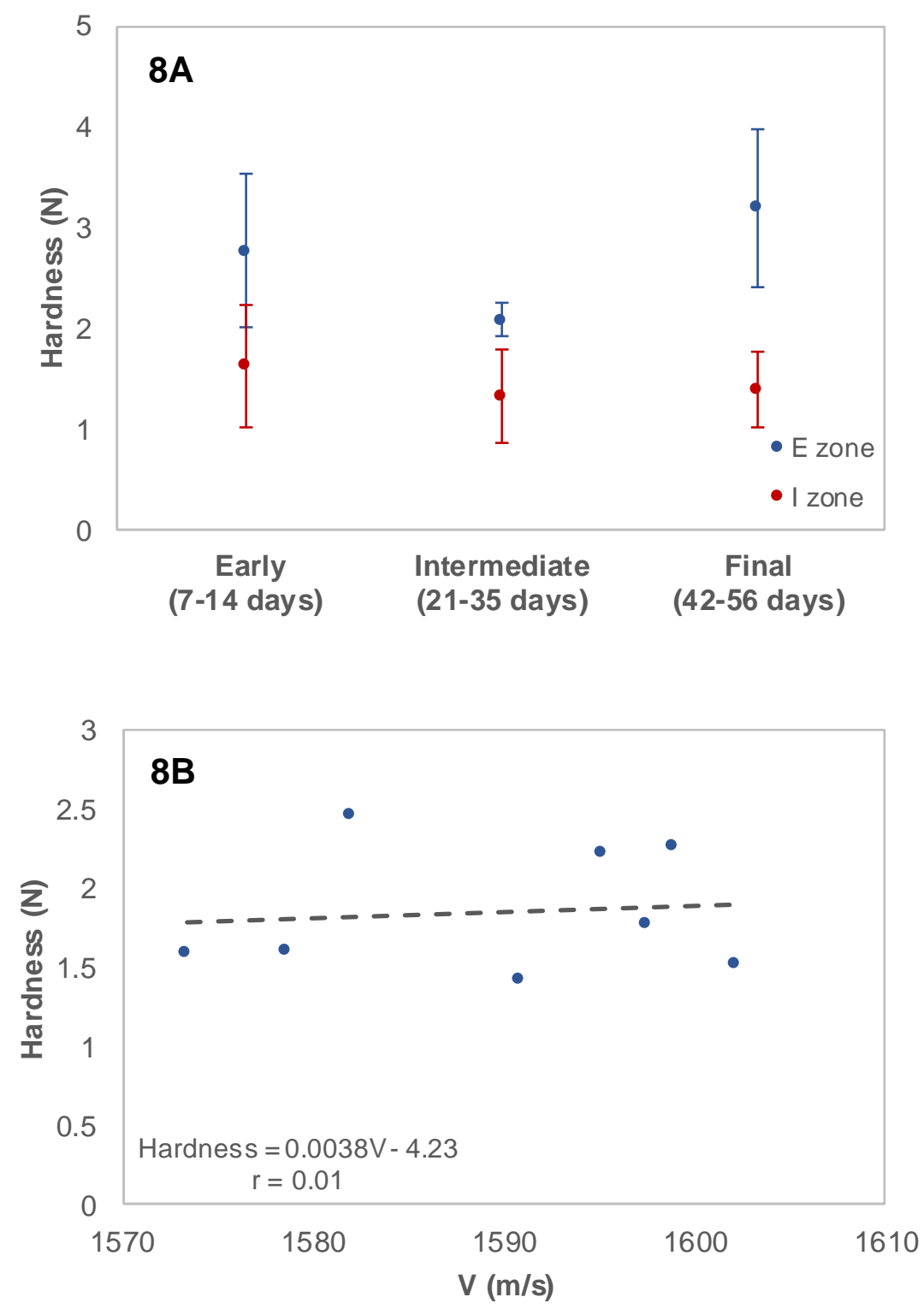

Figure 8. Evolution of hardness $(\mathrm{N})$ in the external $(\mathrm{E})$ and internal $(\mathrm{I})$ zones of the hams grouped depending on the post-salting time: hams post-salted 7 and 14 days (early post-salting), hams postsalted from 21 to 35 days (intermediate post-salting) and hams post-salted from 42 to 56 days (final post-salting). Error bars show LSD intervals (95\%) (8A). Relationship between hardness and ultrasonic velocity during ham post-salting. Each point corresponds to a different ham (8B).

No significant ( $p>0.05$ ) relationship between the average ultrasonic velocity and hardness was found (Figure 8B), which confirms that textural modifications are very moderate during postsalting and the changes of ultrasonic velocity are mostly linked to compositional modifications (salt gain, salt distribution and moisture loss). Ultrasound technology has been previously used to monitor textural changes in dry-cured ham. In this regard, Corona et al. (2013) found a significant relationship $(\mathrm{p}<0.01)$ between the ultrasonic velocity and the hardness changes occurred on vacuum packaged dry-cured ham slices provoked by a high pressure treatment and cold storage, 
finding that the hardest the ham, the fastest the ultrasonic velocity. Contreras et al. (2020) used the ultrasonic attenuation to discriminate between sliced hams with different levels of pastiness, which is a textural defect defined as an unusual softness texture with a lack of elastic behavior. These authors found out that the higher the pastiness level, the higher the ultrasonic attenuation due to the damping phenomenon that produces the more viscous nature of the pasty ham structure on the ultrasonic wave (You et al., 1991).

\section{Conclusions}

Non-destructive ultrasound testing was used to monitor dry-cured ham post-salting (until 56 days). During post-salting, the hams suffered a moderate dehydration, which was well characterized by the ultrasonic velocity. Thus, a linear pattern was found between the weight loss and the change of the ultrasonic velocity. Moreover, the ultrasound velocity was also well related to the change of salt and moisture content. Noticeable changes of texture were not detected in the hams during post-salting. Therefore, it could be concluded that ultrasound is a feasible technology to monitor non-destructively the compositional changes occurring during ham post-salting.

\section{Acknowledgements}

The authors acknowledge the financial support from the "Spanish Ministerio de Economía y Competitividad (MINECO), Instituto Nacional de Investigación y Tecnología Agraria y Alimentaria (INIA)" in Spain, European Regional Development Fund (ERDF 20142020) (Project RTA2013-00030-C03-02) and the PhD grant of M. Contreras from the Universitat Politècnica de València. 


\section{References}

Aliño, M., Grau, R., Toldrá, F., \& Barat, J. M. (2010). Physicochemical changes in dry-cured hams salted with potassium, calcium and magnesium chloride as a partial replacement for sodium chloride. Meat Science, 86, 331-336.

Antequera, T., Caro, A., Rodríguez, P. G., \& Pérez, T. (2007). Monitoring the ripening process of Iberian ham by computer vision on magnetic resonance imaging. Meat Science, 76, 561567.

AOAC. (1997). Official Methods 950.46. In Official Methods of Analysis (sixteenth ed.).

Arnau, J., Gou, P., \& Comaposada, J. (2003). Effect of the relative humidity of drying air during the resting period on the composition and appearance of dry-cured ham surface. Meat Science, 65, 1275-1280.

Barat, J. M., Grau, R., Pagán-Moreno, M. J., \& Fito, P. (2004). Replacement of pile salting by simultaneous brine thawing-salting in Spanish cured ham manufacturing. Meat Science, 66, 603-608.

Barretto, T. L., Rodrigues Pollonio, M. A., Telis-romero, J., \& da Silva Barretto, A. C. (2018). Improving sensory acceptance and physicochemical properties by ultrasound application to restructured cooked ham with salt ( $\mathrm{NaCl}$ ) reduction. Meat Science, 145, 55-62.

Benedito, J., Carcel, J.A., Clemente, G., \& Mulet, A. (2000a). Cheese maturity assessment using ultrasonics. Journal of Dairy Science, 83, 248-254.

Benedito, J., Carcel, J. A., Sanjuan, N., \& Mulet, A. (2000b). Use of ultrasound to assess Cheddar cheese characteristics. Ultrasonics, 38, 727-730.

Coll-Brasas, E., Arnau, J., Gou, P., Lorenzo, J. M., García-Pérez, J. V., \& Fulladosa, E. (2019). Effect of high pressure processing temperature on dry-cured hams with different textural characteristics. Meat Science, 152, 127-133.

Contreras, M., Benedito, J., Quiles, A., Lorenzo, J. M., Fulladosa, E., Gou, P., \& Garcia-Perez, J. V. (2020). Assessing the textural defect of pastiness in dry-cured pork ham using chemical, microstructural, textural and ultrasonic analyses. Journal of Food Engineering, 265, 109690.

Corona, E., García-Pérez, J. V., Mulet, A., \& Benedito, J. (2013). Ultrasonic assessment of textural changes in vacuum packaged sliced Iberian ham induced by high pressure treatment or cold storage. Meat Science, 95, 389-395.

de Prados, M., García-Pérez, J. V., \& Benedito, J. (2015). Non-destructive salt content prediction in brined pork meat using ultrasound technology. Journal of Food Engineering, 154, 39-48.

de Prados, M., Garcia-Perez, J. V., \& Benedito, J. (2016). Ultrasonic characterization and online monitoring of pork meat dry salting process. Food Control, 60, 646-655.

de Prados, M., Garcia-Perez, J. V., \& Benedito, J. (2017). Non-invasive ultrasonic technology for continuous monitoring of pork loin and ham dry salting. Meat Science, 128, 8-14.

Fantazzini, P., Gombia, M., Schembri, P., Simoncini, N., \& Virgili, R. (2009). Use of Magnetic $-93-$ 
Resonance Imaging for monitoring Parma dry-cured ham processing. Meat Science, 82, 219-227.

Garcia-Perez, J. V., de Prados, M., Martinez, G., Gomez Alvarez-Arenas, T. E., \& Benedito, J. (2019). Ultrasonic online monitoring of the ham salting process. Methods for signal analysis: Time of flight calculation. Journal of Food Engineering, 263, 87-95.

Gil-Sánchez, L., Garrigues, J., Garcia-Breijo, E., Grau, R., Aliño, M., Baigts, D., \& Barat, J. M. (2015). Artificial neural networks (Fuzzy ARTMAP) analysis of the data obtained with an electronic tongue applied to a ham-curing process with different salt formulations. Applied Soft Computing Journal, 30, 421-429.

Grau, R., Albarracín, W., Pérez, M. T., Antequera, T., \& Barat, J. M. (2011). Use of simultaneous brine thawing/salting in dry-cured Iberian ham production. Journal of Food Engineering, 104, 316-321.

Grau, R., Albarracín, W., Clemente, G., \& Barat, J. M. (2007). Study of the influence of product and process variables in the salting and post-salting stages of PSE thawed hams. International Journal of Food Engineering, 3, 1-16.

Harkouss, R., Chevarin, C., Daudin, J. D., Sicard, J., \& Mirade, P. S. (2018). Development of a multi-physical finite element-based model that predicts water and salt transfers, proteolysis and water activity during the salting and post-salting stages of the dry-cured ham process. Journal of Food Engineering, 218, 69-79.

Håseth, T. T., Sørheim, O., Høy, M., \& Egelandsdal, B. (2012). Use of computed tomography to study raw ham properties and predict salt content and distribution during dry-cured ham production. Meat Science, 90, 858-864.

Kuo, F. J., Sheng, C. T., \& Ting, C. H. (2008). Evaluation of ultrasonic propagation to measure sugar content and viscosity of reconstituted orange juice. Journal of Food Engineering, 86, 84-90.

Santos-Garcés, E., Muñoz, I., Gou, P., Sala, X., \& Fulladosa, E. (2012). Tools for studying drycured ham processing by using computed tomography. Journal of Agricultural and Food Chemistry, 60, 241-249.

Valente, M., Prades, A., \& Laux, D. (2013). Potential use of physical measurements including ultrasound for a better mango fruit quality characterization. Journal of Food Engineering, $116,57-64$.

Vestergaard, C., Erbou, S. G., Thauland, T., Adler-Nissen, J., \& Berg, P. (2005). Salt distribution in dry-cured ham measured by computed tomography and image analysis. Meat Science, 69 , $9-15$.

You, Z., Lusk, M., Ludwig, R., \& Lord, W. (1991). Numerical simulation of ultrasonic wave propagation in anisotropic and attenuative solid materials. IEEE Transactions on Ultrasonics, Ferroelectrics, and Frequency Control, 38, 436-445. 


Journal of Food Engineering, 2020, 265, 109690.

Assessing the textural defect of pastiness in dry-cured pork ham using chemical, microstructural, textural and ultrasonic analyses

\author{
Marina Contreras ${ }^{1}$, Jose Benedito ${ }^{1}$, Amparo Quiles ${ }^{1}$, Jose Manuel \\ Lorenzo $^{2}$, Elena Fulladosa ${ }^{3}$, Pere Gou ${ }^{3}$, Jose Vicente Garcia-Perez ${ }^{1}$
}

${ }^{1}$ Grupo de Análisis y Simulación de Procesos Agroalimentarios (ASPA). Departamento de Tecnología de Alimentos. Universitat Politècnica de València. Camí de Vera s/n, Valencia (46022), Spain.

${ }^{2}$ Centro Tecnológico de la Carne (CTC). Parque Tecnolóxico de Galicia. Avenida de Galicia 4, San Cibrao das Viñas (32900), Ourense, Spain.

${ }^{3}$ Institut de Recerca i Tecnologia Agroalimentàries (IRTA), Finca Camps i Armet, Monells (17121), Girona, Spain. 



\title{
Assessing the textural defect of pastiness in dry-cured pork ham using chemical, microstructural, textural and ultrasonic analyses
}

\begin{abstract}
The dry-cured pork ham industry lacks non-destructive quality control techniques able to characterize relevant textural defects, such as pastiness or softness. The aim of this study is to analyze the feasibility of using different destructive and non-destructive techniques to characterize pastiness in dry-cured ham. Dry-cured ham processing was modified in order to induce different pastiness intensities over a wide range of moisture and salt contents. Afterwards, pastiness was assessed by sensory analysis and samples classified as non-pasty, medium-pasty and highly-pasty. Finally, chemical, textural, microstructural (LM and TEM) and ultrasonic analyses (velocity and attenuation coefficient) were carried out.
\end{abstract}

Samples with a high degree of pastiness experienced an increase of $16.8 \%$ and $16.7 \%$ as regards the proteolysis index and relaxation capacity, respectively, and a $67.7 \%$ decrease in hardness compared to non-pasty hams. The microstructural analysis revealed that pastiness brought about great structural degradation. Ultrasonic velocity was significantly related to the salt $(\mathrm{r}=0.79)$ and moisture contents $(\mathrm{r}=0.69)$, but no influence of pastiness was found on the velocity. However, the attenuation coefficient increased as the pastiness rose and could be considered as a useful parameter for characterizing this complex textural defect. Therefore, ultrasound could be used not only to carry out a non-destructive characterization of dry-cured ham composition but also to assess pastiness.

Keywords: dry-cured ham, pastiness, texture, microstructure, ultrasound. 


\section{Introduction}

Currently, consumer trend is focusing on reducing the intake of salt in our diets. As one means of reaching this objective, and taking into account that processed meat products constitute one of the major sources of sodium chloride in the diet (Desmond, 2006), dry-cured ham manufacturers are trying to reduce the salt content, while preserving the quality of the final product. Notwithstanding this, salt reduction during processing leads to an excessive proteolytic activity (Parolari et al., 1994; Virgili et al., 1995), resulting in soft, pasty textures (pastiness). Moreover, inherent properties linked to the raw material, such as $\mathrm{pH}$ or high water content, have also been identified as factors influencing pastiness, which underlines the complexity of avoiding its incidence and intensity during industrial processing (Morales et al., 2007b). Specifically, pastiness in dry-cured ham is defined as the loss of elasticity in the muscle and, in sensory terms, as a mouth-coating sensation during mastication. The texture of dry-cured ham is one of its most highly-appreciated attributes and notably influences consumer acceptability (Morales et al., 2007a), which highlights the need for its adequate characterization.

Previous literature has already made some attempts to deal with the assessment of pastiness. Thus, Morales et al. (2007a) evaluated the feasibility of two different instrumental texture tests (TPA and stress relaxation) to discriminate between defective and non-defective ham slices, assessing the impact of the assay conditions (temperature and compression crosshead speed) on the characterization results. Likewise, sensory analysis, some chemical properties ( $\mathrm{pH}$, salt, moisture, non-protein nitrogen, etc.), proteomic profile and volatile compounds of defective dry-cured ham have also been considered for the characterization of pastiness (Garcia-Garrido et al., 1999; López-Pedrouso et al., 2018; Pérez-Santaescolástica et al., 2018). However, existing literature reveals the need for a deeper understanding and characterization of pastiness. Previous studies lack a significant number of samples studied over a wide range of pastiness levels. In addition, the fact that commercial hams have mostly been used, indicates that these studies are influenced by the interference of the salt content in the appearance and intensity of pastiness. Moreover, to the best of our knowledge, there has been no previous analysis of pasty ham microstructure, which could provide interesting information with which to understand the changes that take place in this type of texturally defective product.

Sensory, chemical and textural analyses are laborious, relatively slow and destructive. More rapid and non-invasive technologies have been tested to assess pastiness in dry-cured ham. Thus, laser-light backscattering has been used in commercial, sliced dry-cured ham to determine proteolysis, which is a parameter related to the textural characteristics of the product (Fulladosa et al., 2017). However, they found that the scattering area was similar for every level of proteolysis. Additionally, Fulladosa et al. (2018) studied the feasibility of multi energy X-ray to detect changes in dry-cured ham slices after inducing proteolysis, finding a limitation when discriminating between levels of proteolysis because of the interference of the salt and water 
contents on the X-ray attenuation. As an alternative, low intensity ultrasound could be considered a feasible technology for the purposes of characterizing food composition and texture in a nondestructive way (Benedito et al., 2000; Corona et al., 2013b). The automated, cost-effective, nondestructive and minimally invasive characteristics of ultrasound facilitate its in-line implementation in the industry. In the meat sector, there are extensive references to the use of ultrasonics for non-destructive testing, which could be explained by considering the significant economic importance of this sector and the lack of reliable non-destructive alternatives for in-line implementation. Thus, ultrasound has been used to determine fat and/or water content in meatbased products (sobrassada, sausages) (Benedito et al., 2001; Simal et al., 2003), in Biceps femoris muscle from Iberian pork (Niñoles et al., 2011), in green pork hams (de Prados et al., 2015a) and in Iberian dry-cured ham slices (Corona et al., 2013a) through ultrasonic velocity measurements. Likewise, ultrasound has been used to estimate the salt content in brined (de Prados et al., 2015b) and in dry salting (de Prados et al., 2016) Biceps femoris and Longissimus dorsi pork muscle, as well as in hams (de Prados et al., 2016). Corona et al. (2014) also analyzed the crystallization pattern of two types of Iberian pork fat during cooling, finding out that ultrasonic measurements were useful both to differentiate between fats of differing composition and to characterize the textural changes taking place. As regards food textural properties assessed by ultrasound, Nowak et al., (2015) compared the mechanical properties of sausages estimated by means of both a compression test and by acoustic measurements and concluded that they did not significantly differ. Furthermore, ultrasonic velocity has been used to evaluate the texture of a meat-based product (Llull et al., 2002) and the textural changes undergone by high pressure treated vacuumpacked dry-cured ham slices during cold storage (Corona et al., 2013a). Similarly, ultrasound has been applied to detect textural changes both in beef from old livestock (Dwyer et al., 2001) and under stress conditions (Swatland, 2001), which may be used as quality indicators of beef meat. In this sense, rapid and non-destructive ultrasound measurements could be useful to assess pastiness, permitting the inline separation of defective from non-defective dry-cured hams. In this way, hams with a high degree of pastiness would not be placed on the market, ensuring a homogeneous and high quality product. Moreover, once defective hams were detected and separated, subsequent corrective treatments could also be applied.

Considering what is mentioned above, the objective of this study was to gain greater knowledge as regards the characterization of ham pastiness from a physicochemical and microstructural point of view, as well as to evaluate the feasibility of using ultrasound to detect pastiness in dry-cured ham. 


\section{Materials and methods}

\subsection{Ham elaboration process and sampling procedure}

Two hundred hams $(\mathrm{pH}<5.5$ measured in Semimembranosus muscle after $24 \mathrm{~h}$ postmortem) from Large White and Landrace animal breed crosses were supplied by a commercial slaughterhouse. Initial average weight of hams was $11.9 \pm 1.1 \mathrm{~kg}$. In order to induce pastiness of different intensities in hams, a customized elaboration process was conducted. Hams were manually rubbed with the following mixture ( $\mathrm{g} / \mathrm{kg}$ of raw ham): 0.15 of $\mathrm{KNO}_{3}, 0.15$ of $\mathrm{NaNO}_{2}, 1.0$ of dextrose, 0.5 of ascorbic acid and 10 of $\mathrm{NaCl}$, and then pile salted $\left(3 \pm 2{ }^{\circ} \mathrm{C}, 85 \pm 5 \%\right.$ $\mathrm{RH}$ ) for 4, 6, 8 and 11 days ( $\mathrm{n}=200,50$ hams per salting time). After salting, the superficial salt was removed by using compressed air and afterwards, the hams were brought to post-salting for 45 days $\left(3 \pm 2{ }^{\circ} \mathrm{C}, 85 \pm 5 \% \mathrm{RH}\right)$. Once post-salting finished, the hams were subjected to an initial convective drying process $\left(12 \pm 2{ }^{\circ} \mathrm{C}, 70 \pm 5 \% \mathrm{RH}\right)$ in order to reduce their weight by $29 \%$. After initial drying, the hams were vacuum-packed and kept at $30^{\circ} \mathrm{C}$ for 30 days trying to induce high proteolysis levels in a large number of hams. Afterwards, the hams were unwrapped and subjected to a second drying process $\left(12 \pm 2{ }^{\circ} \mathrm{C}, 65 \pm 5 \% \mathrm{RH}\right)$, which was extended until a final weight loss of $34 \%$ was reached. Subsequently, the hams were vacuum-packed and kept at $30^{\circ} \mathrm{C}$ for 30 days. Finally, the unwrapped hams were dried until a final weight loss of $36 \%$ was attained. On average, the drying stage lasted approximately 400 days.

Once the elaboration process ended, the femur bone was removed and the aitch bone and the butt end were cut before the cushion part of the ham was excised in order to obtain different slices. Three slices $(1.5 \mathrm{~mm}$ thick) were used for sensory characterization and one slice $(20 \mathrm{~mm}$ thick) was employed for physicochemical, microstructural and ultrasonic analyses. The slices were vacuum-packed in individual plastic bags of polyamide/polyethylene (oxygen permeability of $50 \mathrm{~cm}^{3} / \mathrm{m}^{2} / 24 \mathrm{~h}$ at $23{ }^{\circ} \mathrm{C}$ and a water permeability of $2.6 \mathrm{~g} / \mathrm{m}^{2} / 24 \mathrm{~h}$ at $23{ }^{\circ} \mathrm{C}$ and $85 \% \mathrm{RH}$, Sacoliva ${ }^{\circledR}$ S.L., Spain) and stored at $4 \pm 2{ }^{\circ} \mathrm{C}$ until the analysis was performed.

\subsection{Sensory texture analysis}

A three-member expert panel, trained following the American Society for Testing and Materials standards (ASTM SPT 758, 1981), performed the sensory texture analysis. The only textural attribute evaluated in the Biceps femoris (BF) muscle was pastiness, which can be defined as a feeling similar to the mouth-coating sensation produced by flour-water paste during the mastication process. The dry-cured ham pastiness level was ranked from score 0 (absence) to 6 (maximum intensity). The pastiness level of the samples was set as the average score of the three experts. Thus, the textural defect of the dry-cured ham was used to classify it into the following sample groups: non-pasty (pastiness level<1), medium-pasty (pastiness level between 1 and 2.5) and highly-pasty (pastiness level>2.5). 


\subsection{Chemical analyses}

The $\mathrm{pH}$ was measured using a Crison Basic $\mathrm{pH}$ meter (Crison Instruments S.A., Barcelona, Spain). The salt content was analysed using a potentiometric titrator 785 DMP Titrino (Metrohm AG, Herisau, Switzerland) following standard methods (ISO1841-2, 1996) and the results were expressed as a percentage of $\mathrm{NaCl}$ on a wet basis (w.b.). The moisture content was determined by oven drying to constant weight at $103 \pm 2{ }^{\circ} \mathrm{C}$ following the standard AOAC method, 950.46 (AOAC, 1997). The proteolysis index (PI, \%) was calculated as the ratio between nonprotein nitrogen and total nitrogen content following the methodology reported by Schivazappa et al. (2002). All the analyses were carried out in triplicate.

\subsection{Microstructural evaluation}

The dry-cured ham microstructure was observed using two microscopic techniques: light microscopy (LM) and transmission electron microscopy (TEM). From slices $1.5 \mathrm{~mm}$ thick, small sections $(5 \times 3 \mathrm{~mm}$ ) were cut from BF muscle with a disposable blade. In order to obtain included sections, the samples were fixed with a $25 \mathrm{~g} / \mathrm{L}$ glutaraldehyde solution $(0.025 \mathrm{M}$ phosphate buffer, pH 6.8 , at $4{ }^{\circ} \mathrm{C}, 24 \mathrm{~h}$ ), postfixed with a $20 \mathrm{~g} / \mathrm{L} \mathrm{OsO}_{4}$ solution $(1.5 \mathrm{~h})$, dehydrated using a graded acetone series $(300,500,700$ and $1000 \mathrm{~g} / \mathrm{kg}$ ), contrasted in $40 \mathrm{~g} / \mathrm{L}$ uranyl acetate dissolved in acetone and embedded in epoxy resin (Durcupan, Sigma-Aldrich, St. Louis, MO, USA). The samples were cut using a Reichert Jung ultramicrotome (Leica Mycrosystems, Wetzlar, Germany). Thin sections $(1.5 \mu \mathrm{m})$ were stained with $2 \mathrm{~g} / \mathrm{L}$ toluidine blue and examined in a Nikon Eclipse E800 light microscope (Nikon, Tokyo, Japan). Ultrathin sections $(0.5 \mu \mathrm{m})$ were stained with $40 \mathrm{~g} / \mathrm{L}$ lead citrate and observed in a PhilipsEM400 (Philips, Eindhoven, Holland) transmission electronic microscope at $80 \mathrm{kV}$.

\subsection{Instrumental texture analyses}

From dry-cured ham slices, 5 parallelepipeds of BF muscle were carved (20 mm length $\mathrm{x}$ $20 \mathrm{~mm}$ width $\mathrm{x} 15 \mathrm{~mm}$ height). The textural properties of dry-cured ham parallelepipeds were measured using a TA-XT2 texturometer (SMS, Godalming, UK) provided with a load cell of 50 $\mathrm{kg}$. Stress-relaxation tests were carried out at a constant temperature $\left(4 \pm 2^{\circ} \mathrm{C}\right)$ using a flat $75 \mathrm{~mm}$ diameter aluminum plunger (SMS P/75). The samples were compressed to $25 \%$ of their initial height perpendicularly to the fiber bundle direction at a crosshead speed of $1 \mathrm{~mm} / \mathrm{s}$ and afterwards, the probe was held for $90 \mathrm{~s}$ to monitor relaxation. The experimental data were recorded and processed with Exponent Lite 6.1.4.0 software (SMS, Godalming, UK). Thus, hardness was computed from the force versus time profiles as the maximum force achieved during compression $\left(\mathrm{F}_{0}\right)$ and the level of force decay $\mathrm{Y}_{\mathrm{t}}$ logged during relaxation was calculated as follows: 


$$
Y_{t}=\frac{F_{0}-F_{t}}{F_{0}}
$$

where $F_{0}$ is the maximum force during compression $(\mathrm{N})$ and $F_{t}$ is the force recorded after $\mathrm{t}$ seconds of relaxation. $Y_{t}$ was calculated at $\mathrm{t}=2 \mathrm{~s}$ of the relaxation period and at the end of the stressrelaxation test $(\mathrm{t}=90 \mathrm{~s})$.

\subsection{Ultrasonic experimental set-up and measurements}

Ultrasonic measurements were taken in BF muscle. As shown in Figure 1A, circular measuring points (matching transducer diameter of 1') were marked on the plastic bag in order to cover the maximum surface of the BF.

A custom fully automatic ultrasonic prototype was designed and built by the ASPA research Group of the Universitat Politècnica de València in order to characterize the dry-cured ham slices. The system is made up of seven main elements, as shown in Figure 1B, and can be operated in both pulse-echo and through-transmission ultrasonic measurement modes. In this study, ultrasonic measurements were taken in through-transmission mode using a pair of aligned narrow-band transducers (1 MHz, 1" diameter, A314S model, Panametrics, Waltham, MA, USA). For that purpose, the receiver transducer (Figure 1B, 3) was embedded in the base of the measurement platform, while the emitter (Figure 1B, 2) was attached to the edge of a rod slide electric actuator moved by a step motor (LEY 16RB model, SMC, Tokyo, Japan) (Figure 1B, 1) and controlled (LECP6N model, SMC, Tokyo, Japan) (Figure 1B, 7) and operated under supervision using a computer (Figure 1B, 6).

The slice of ham was placed over the receiver transducer and the emitter was moved down by the electric actuator until it reached the slice (initial lowering speed of $250 \mathrm{~mm} / \mathrm{s}$ until a distance between transducers of $40 \mathrm{~mm}$ was reached; final lowering speed of $1 \mathrm{~mm} / \mathrm{s}$ until $17 \mathrm{~N}$ of pushing force was exerted on the sample). The pushing force of the transducer on the sample was fixed through the electrical actuator as a threshold to stop the transducer, providing an appropriate sample-transducer coupling and avoiding excessive sample deformation. In addition, tap water was used as coupling material. The electrical actuator was also used to measure the thickness of the slice $( \pm 0.01 \mathrm{~mm})$.

The pulser-receiver (5058PR model, Panametrics, Waltham, MA, USA) (Figure 1B, 4) working in through-transmission mode (gain $40 \mathrm{~dB}$; excitation voltage $(100-400 \mathrm{~V}$ ) and attenuation (0-40 dB) set depending on the sample requirements) supplied a spike pulse to the emitter transducer (Figure 1B, 2) and also filtered (high pass filter, $1 \mathrm{MHz}$ ) and conditioned the electrical signal received from the ultrasonic receiver transducer. Finally, the ultrasonic signal was digitized (sampling frequency $100 \mathrm{Ms} / \mathrm{s}$ ) by an oscilloscope (USB-5133 model, National Instruments, Austin, USA) (Figure 1B, 5) and sent to the computer for analysis (Figure 1B, 6). 
An application was developed in LabVIEW ${ }^{\mathrm{TM}}$ (National Instruments, Austin, Texas) to integrate the movement of the transducer, the measurement of the sample thickness and the acquisition and recording of the ultrasonic signal.

The number of experimental measurement points marked on the BF was between 5 and 6 (Figure 1A). An average of 10 signal acquisitions were carried out for each measurement point.
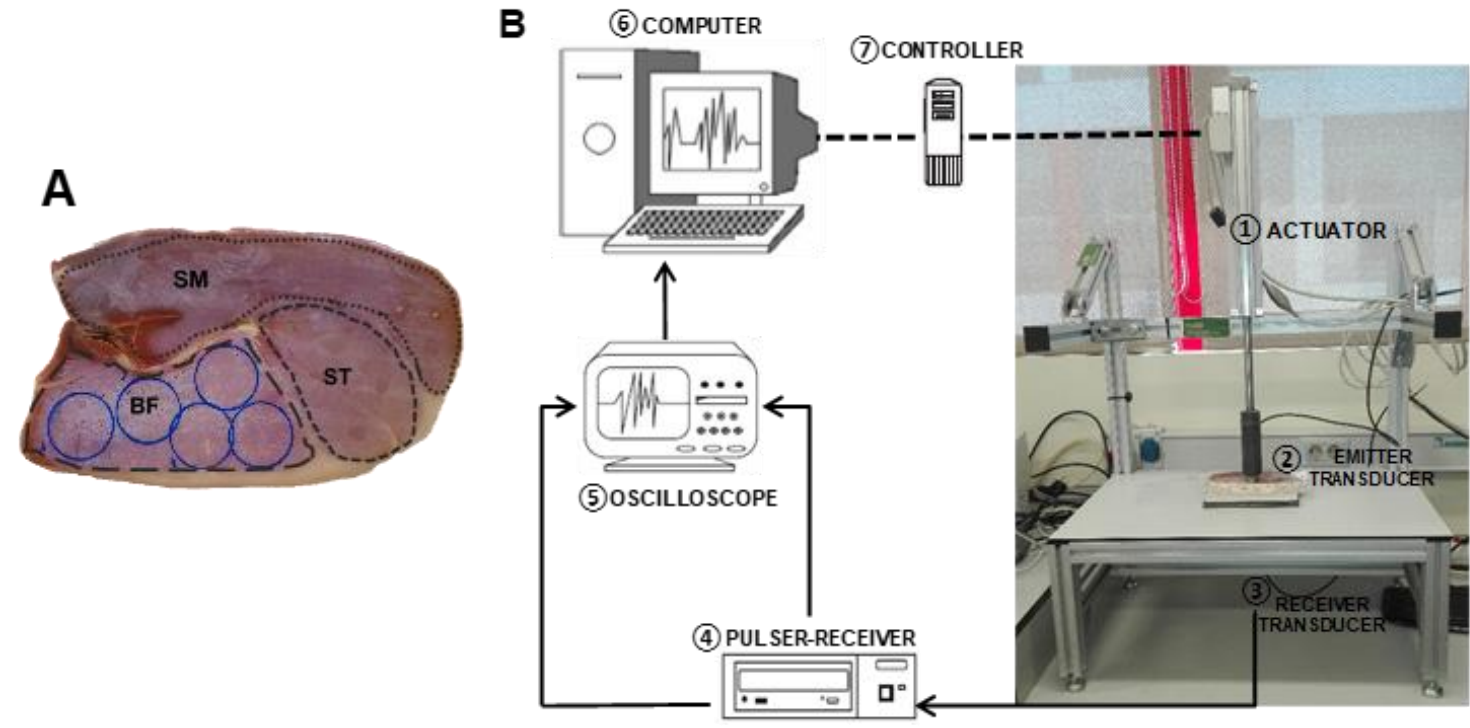

Figure 1. A: Slice of deboned dry-cured ham. The three main muscles are shown: Biceps femoris (BF), Semitendinosus (ST) and Semimembranosus (SM). Circular measurement points for ultrasonic analysis were marked on BF muscle. B: Diagram of the ultrasonic experimental set-up.

\subsection{Ultrasonic signal analysis and parameter determination}

Figure 2 illustrates a characteristic ultrasonic signal acquired for the dry-cured ham slices using the experimental set-up described in section 2.6. In Figure 2, three wavefront arrivals are observed. The first wavefront arrival corresponds to the direct transit of the ultrasonic signal from the emitter to the receiver transducer and is voltage-saturated (signal is trimmed above $\pm 1.1 \mathrm{~V}$ amplitude). The second and third wavefront arrivals (Figure 2) correspond to the two consecutive wave reflections between transducers and are not saturated. Thereby, ultrasonic velocity was measured from the first wavefront arrival, while for the attenuation coefficient, the second and third wavefronts were considered. Consequently, the time of flight of the ultrasonic signal was computed by using the energy threshold method (upper and lower thresholds 0.1 and $-0.1 \mathrm{~V}$, respectively) applied to the first wavefront arrival and considering the system delay $(0.7895 \mu \mathrm{s})$, as described by de Prados et al. (2015a). Thus, the ultrasonic velocity was computed as the ratio between the sample thickness and the time of flight. For the attenuation calculation, the analysis was performed in the frequency domain by applying the Fast Fourier Transform (FFT) to the time domain signal. Data in the frequency domain is a complex number consisting of a module and a phase that give rise to a module spectrum (amplitude) and phase spectrum (frequency), respectively. From the frequency domain, the ultrasonic attenuation coefficient ( $\alpha$, Eq. 2$)$ was 
calculated by computing the maximum amplitude of the spectrum corresponding to the second and third wavefront arrivals of energy:

$$
\alpha=\frac{\operatorname{Ln}\left(\frac{P_{3}}{P_{2}}\right)}{2 L}
$$

where $P_{3}$ and $P_{2}$ are the maximum amplitudes in the spectrum of the third and second wavefront arrivals of the ultrasonic signal, respectively, and $L$ is the sample thickness.

Finally, the average ultrasonic velocity and attenuation coefficient of BF, computed from the 50-60 acquired signals per slice, was correlated to the textural, chemical and sensory parameters of the dry-cured hams.

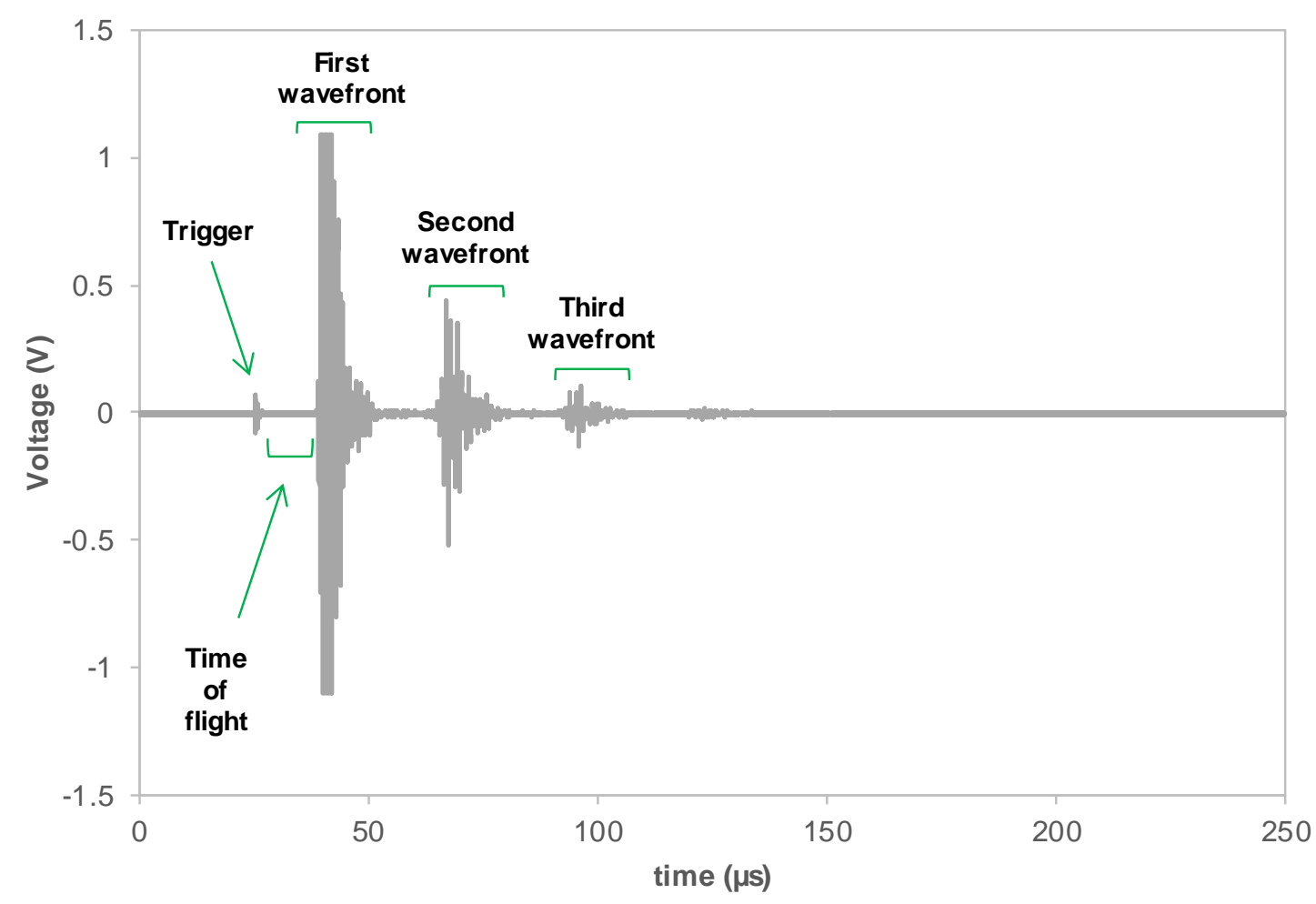

Figure 2. Ultrasonic signal obtained in the through-transmission mode. The first wavefront corresponds to the direct transit of the ultrasonic signal from the emitter to the receiver transducer. Second and third wavefronts correspond to the two consecutive wave reflections between transducers.

\subsection{Statistical analysis}

A one-way analysis of variance (ANOVA) was performed to study the effect of chemical, textural and ultrasonic parameters on the level of pastiness. Subsequently, a linear and polynomial regression was carried out in order to discover a relationship between the level of pastiness and the aforementioned parameters. Eventually, a discriminant analysis was performed to classify the 
samples into NP, MP or HP levels according to the chemical, textural and ultrasonic parameters measured. All the statistical analyses were carried out using Statgraphics Centurion XVI (Statpoint Technologies Inc., Warrenton, VA, USA).

\section{Results and discussion}

\subsection{Levels of pastiness}

Hams were classified into three groups according to their level of sensory pastiness. The average pastiness of the non-pasty (NP) group (pastiness level<1) was $0.3 \pm 0.2$ and it comprised 110 samples. 50 samples were classified into the medium-pasty (MP) group (pastiness level between 1 and 2.5) with an average pastiness of $1.7 \pm 0.5$. The remaining 40 hams belonged to the highly-pasty (HP) group (pastiness level>2.5), reaching an average pastiness of 3.6 \pm 0.3 . These results confirmed that $45 \%$ of the hams obtained using the ham elaboration process described in section 2.1 had a measurable level of pastiness. Further sections will address the characterization of pastiness by means of chemical, textural, microscopy and ultrasonic techniques.

\subsection{Chemical characterization of pastiness}

Earlier literature suggested that salt and water contents had a strong influence on the incidence, not only of pastiness, but also of the so-called soft textures in commercial dry-cured hams. Thereby, Gou et al. (2008) reported that defective hams with soft textures presented a lower amount of salt compared to the average quantity found in commercial ones. In a similar way, Serra et al. (2005) affirmed that an excessive moisture content led to softer textures in hams. High salt contents protect the ham from the action of proteolytic enzymes responsible for the intense proteolysis found in pasty dry-cured hams (Pérez-Santaescolástica et al., 2018). This explains why the intensity of pastiness in standard commercial hams increases as does the probability of the incidence of the defect in the case of low salt contents. In the same way, high water contents promote proteolytic activity, which also fosters the appearance of an increase in pastiness.

The processing conditions used in this study (section 2.1) permitted the removal of the influence of both the salt and water contents on pastiness. The salt content increased along with the salting time, this being $3.7 \pm 0.4,4.6 \pm 0.5,5.1 \pm 0.5$ and $5.6 \pm 0.7$; w.b. $\%$ for $4,6,8$ and 11 salting days, respectively. However, when the hams were divided according to their pastiness intensity (NP, MP and HP), the three groups presented a similar average salt content (NP: $4.8 \pm 0.1$, MP: $4.8 \pm 0.2$, HP: $4.7 \pm 0.2$; w.b.\%). A linear regression demonstrated that there was no statistically significant $(p>0.05)$ relationship between ham pastiness and salt content $(r=0.0046)$. Analogous results were found for the moisture content, where the three groups of ham pastiness presented similar average moisture contents (NP: $58.9 \pm 0.1$, MP: $58.7 \pm 0.2$, HP: 59.0 \pm 0.2 ; w.b.\%) and the 
correlation between pastiness and moisture was not statistically significant $(p>0.05)$. These results confirmed that, even considering that both salt and moisture content have an intrinsic influence on the appearance and intensity of pastiness, the defect can also appear eventually in hams with a high salt and low moisture content; this is a highly relevant finding, since in earlier literature dealing with pastiness, the salt content always appeared as a significant factor (García-Rey et al., 2004; Morales et al., 2007b). This confirms that the interaction of the processing conditions (excessively high temperatures and vacuum-packaging), may induce the development of pastiness, even at high salt contents.

The proteolysis index (PI) was used for the characterization of pastiness, since a defective texture in ham has been associated with significant proteolysis if compared to ham with a standard texture (Garcia-Garrido et al., 1999; Gou et al., 2008; Ruiz-Ramírez et al., 2006). The range of PI identified for the three groups of pastiness was quite narrow since the values ranged from 28 to $44 \%$. These PI figures were moderately higher than the values reported by Harkouss et al. (2015) studying Bayonne dry-cured hams $(25 \pm 1 \%)$. The statistical analysis carried out for the PI percentage indicated that there exist significant differences $(\mathrm{p}<0.05)$ between groups of pastiness (Table 1), the PI increasing linearly with the intensity of the defect. Thus, the greater the degree of pastiness, the higher the PI; the MP and HP samples exhibited a PI that was nearly 6.6 and $16.8 \%$ greater, respectively, than the NP ones. Virgili et al. (1995) stated that the textural defect was a consequence of abnormal protein cleavage or uncontrolled proteinase activity during ham processing. Figure 3 shows the relationship between PI and pastiness for every ham elaborated in this study, which follows a significant $(\mathrm{p}<0.05)$ linear upward trend. A high degree of variability was found, especially in NP hams (pastiness level<1) where PI ranged from 28 to $37 \%$. The special ham elaboration process carried out in the present study could explain this fact. GarciaGarrido et al. (1999) found a good correlation ( $\mathrm{r}=0.876$ ) between pastiness (sensory assessed) and non-protein nitrogen in dry-cured ham BF muscle, which is a factor directly related to the PI ratio. The close correlation found in that study could be explained by considering that those authors used commercial hams, where salt and moisture contents are directly linked to proteolysis, reducing the experimental variability. Previous studies have related the PI to the salt content. Thus, Morales et al. (2007b) observed that dry-cured ham with different salting levels $(1,2,4 \%)$ led to different PI $(19.3,17.8,16.7 \%$, respectively). However, the PI and the salt content of the hams in this study were not significantly $(\mathrm{p}>0.05)$ related $(\mathrm{r}=0.02)$, which again could be due to the special elaboration process, where pastiness was forced by adding processing stages where water was not allowed to leave the packaged samples and temperature was kept at $30^{\circ} \mathrm{C}$. 
Table 1. Average ( \pm LSD intervals/2) of salt and moisture content, proteolysis index (PI), hardness, force decay at 2 and $90 \mathrm{~s}\left(\mathrm{Y}_{2}\right.$ and $\left.\mathrm{Y}_{90}\right)$, ultrasonic velocity $(\mathrm{V})$ and ultrasonic attenuation coefficient $(\alpha)$ for dry-cured hams grouped into 3 groups of pastiness.

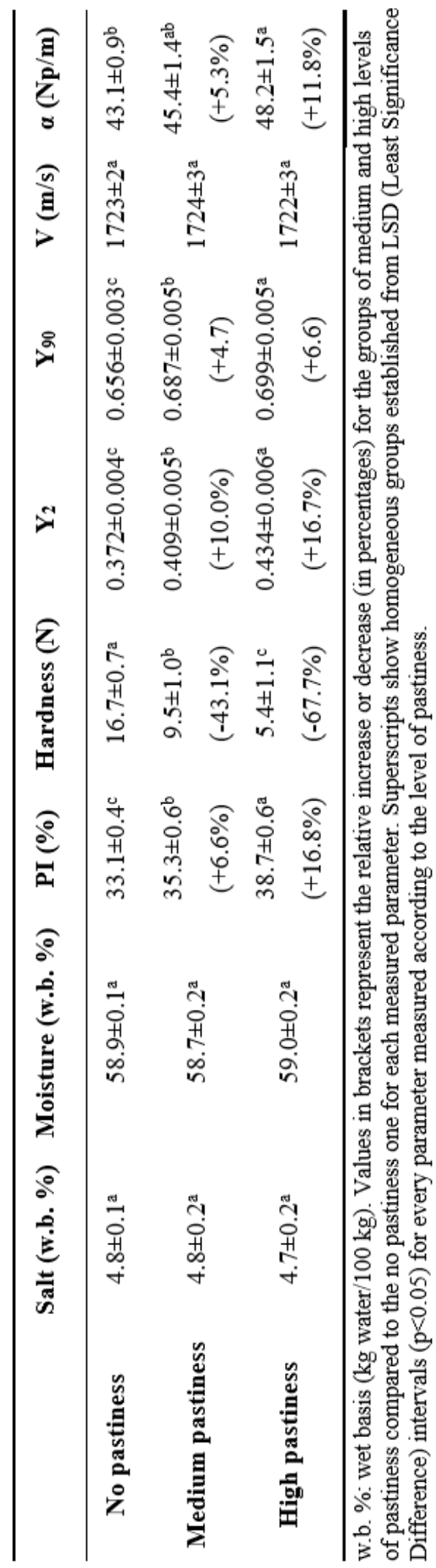




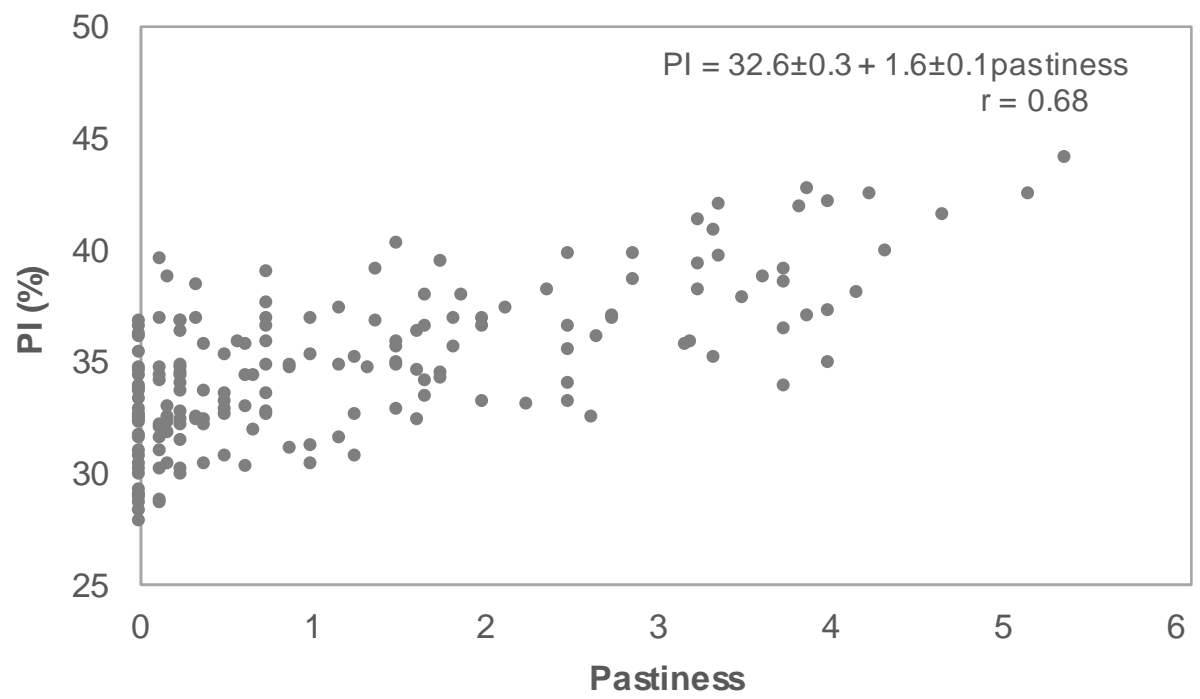

Figure 3. Relationship between pastiness and proteolysis index (PI) in slices of dry-cured ham.

\subsection{Textural characterization of pastiness}

The texture of dry-cured hams was characterized by an instrumental stress-relaxation test, as described in section 2.5. The statistical analysis showed significant $(\mathrm{p}<0.05)$ differences between the hardness of the different groups of pastiness. The samples became softer as the pastiness increased; those dry-cured hams with no textural defects had the highest hardness values (Table 1). Thus, the average hardness of HP ham was $5.4 \pm 1.1 \mathrm{~N}$, nearly $68 \%$ softer than NP samples; in MP samples, meanwhile, the hardness was $9.5 \pm 1.0 \mathrm{~N}, 43 \%$ softer than NP hams. The softer texture of dry-cured ham, classified as HP and MP samples, could be explained by an excessive proteolytic denaturation emerging from the customized elaboration process. In earlier literature, the dry-cured ham texture has been related to the salt content, since salt can affect the proteolytic process and the myofibril structure. Thus, Gou et al. (2008) stated that BF muscle from hams salted for 14 days had a lower degree of pastiness and were harder compared to hams salted for 6 days. In their study, Morales et al. (2007b) also found that the dry-cured ham with the highest salt content (avg. 4\%) exhibited the highest degree of hardness and the lowest PI. However, in the present study, the samples had a similar salt content but a statistically $(\mathrm{p}<0.05)$ different texture in every group of pastiness. The influence of the level of pastiness on the sample hardness is depicted in Figure 4A, which shows how the hardness decreased as the samples grew pastier. As can be observed, a high degree of variability in terms of hardness was found for nondefective samples (pastiness level<1). The best mathematical description of experimental data was found for a polynomial equation (order 3) which explained $57 \%$ of the experimental variability. 

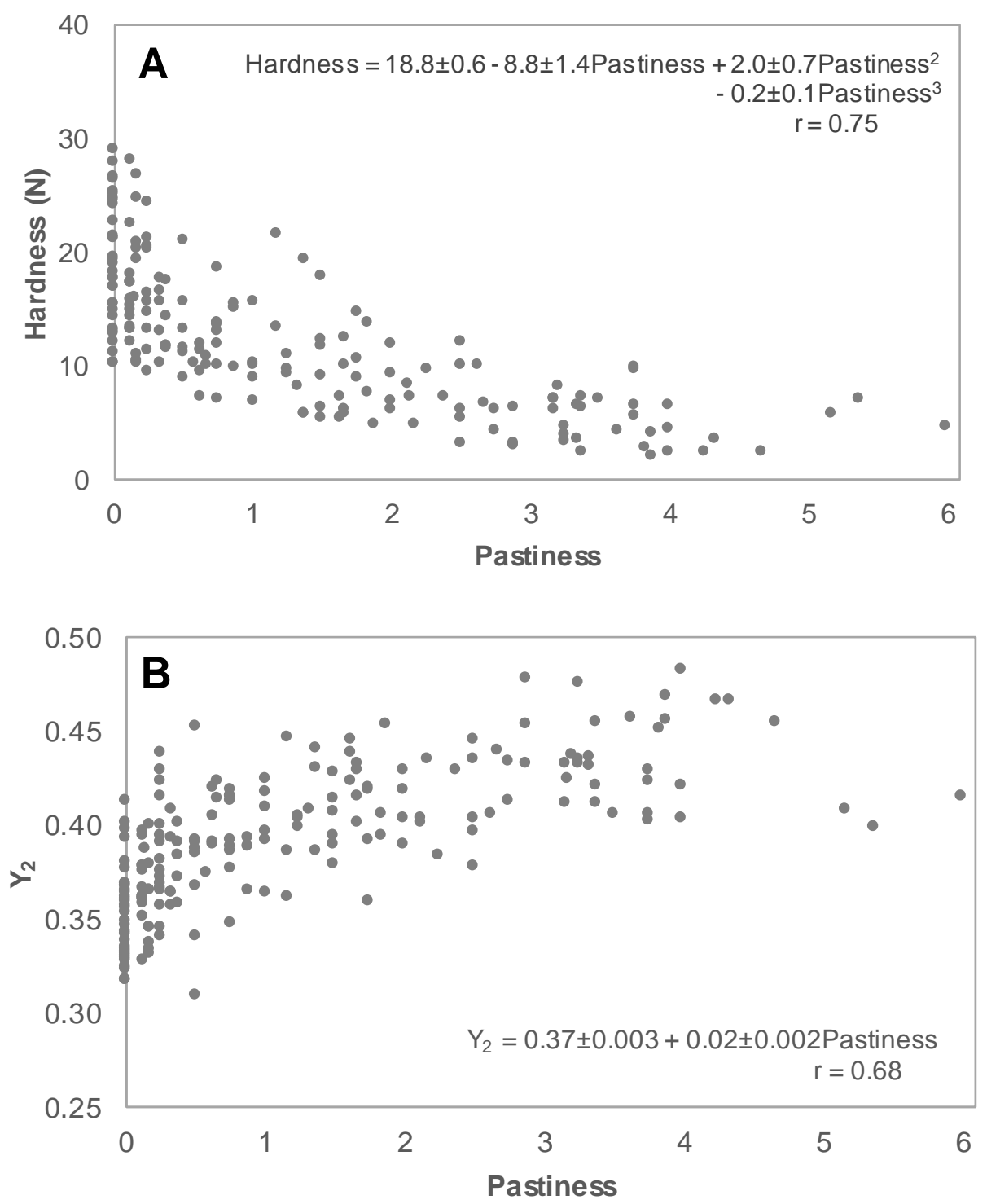

Figure 4. A: Relationship between pastiness and hardness in slices of dry-cured ham. B: Relationship between pastiness and the force decay textural parameter measured at $2 \mathrm{~s}\left(\mathrm{Y}_{2}\right)$ in slices of dry-cured ham.

As for the relaxation properties, both $\mathrm{Y}_{2}$ and $\mathrm{Y}_{90}$ increased as the degree of pastiness rose (Table 1), showing significant differences $(\mathrm{p}<0.05)$ for the three groups of pastiness. As an increase in force decay is linked to a loss in muscle elasticity, higher $\mathrm{Y}_{2}$ and $\mathrm{Y}_{90}$ values indicate lower elasticity. Another study carried out on dry-cured ham with defective texture presented slightly lower values of $\mathrm{Y}_{2}(0.360)$ and higher values of $\mathrm{Y}_{90}$ (0.734) (Morales et al., 2007a) compared to the ones obtained in the present study. The relative increase in $\mathrm{Y}_{2}$ for the samples with medium and high pastiness levels compared to the NP pastiness group was 10 and $16.7 \%$, respectively. In the case of $\mathrm{Y}_{90}$, however, the relative increase with respect to the MP and HP samples was merely 4.7 and $6.6 \%$, respectively, which points to the fact that $Y_{2}$ is a more useful parameter with which to discriminate between pastiness levels than $\mathrm{Y}_{90}$. 
The linear relationship between both $\mathrm{Y}_{2}$ (Figure 4B) and $\mathrm{Y}_{90}$ (data not shown) and pastiness explained 46 and $35 \%$ of the experimental variability, respectively, which represents a moderately strong correlation between both variables. In this sense, similar results were obtained by Gou et al. (2008) who found an analogous tendency between pastiness and instrumental texture parameters in the BF muscle of dry-cured ham: the higher the degree of pastiness, the lower the hardness level and the higher the $\mathrm{Y}_{2}$ and $\mathrm{Y}_{90}$. However, literature has supplied no quantitative relationship between pastiness and the textural parameters.

\subsection{Microstructural characterization of pastiness}

Dry-cured ham muscle tissue was observed by LM and TEM. Figure 5 shows LM (Figure 5, 1-6) and TEM (Figure 5, 7-9) images of BF muscle tissue from dry-cured ham with different levels of pastiness. Inside the cell, gaps can be observed brought about by the processing undergone by the muscle when transformed into ham. Most of the muscle cells are still composed of structured and packed myofibrils, enclosed by sarcolemma membrane (Figure 5, 2). In general, connective tissue that surrounds muscle cells can be seen to be slightly degraded, especially sarcolemma membrane, but the typical cell structure is still observed (Figure 5, 1). In contrast, muscle tissue with a medium level of pastiness (Figure 5, 3-4) is not uniformly stained and significant gaps appear. Some cells are degraded due to myofibril disintegration (Figure 5, 4). Both endomysium and perimysium connective tissues are demoted (Figure 5, 3). Furthermore, the sarcolemma membrane appears degraded in some parts, giving rise to gaps between the myofibrils and the sarcolemma. Finally, in samples with a high level of pastiness (Figure 5, 5-6) muscle tissue does not have structural integrity. In many parts, the sarcolemma membrane and connective tissue are broken down and even disappear. Muscle cells are largely degraded, merged and do not show structural limits. At a microstructural level, pastiness is generally observed as a high degree of disintegration in the tissue, especially in the cell membranes.

As regards the ultrastructure, and as previously observed by Larrea et al. (2007), standard dry-cured ham (Figure 5,7) presents an ultrastructure where the proteolysis originating during the curing process may be appreciated (Benedini et al., 2012). Myofibrils and the filaments they are composed of are slightly degraded with no continuity in some areas, which gives rise to small empty spaces or gaps inside the myofibrils. Structural elements of the myofibril can be partially observed. Thus, the H-zone and "A" band can still be distinguished in many parts of the muscle. Almost the entire length of the sarcomere seems to be occupied by the "A" band, with the "I" band remaining hidden. Z-disks, which mark the length of the sarcomere, can be clearly distinguished, although they are no longer aligned. Furthermore, some structural elements that can be easily appreciated in raw muscle, such as the "I" band (Larrea et al., 2007), disappear in cured muscle probably due to a marked proteolytic activity. Intermyofibrillar protein connections (costamere) that join the myofibrils are degraded, bringing about remarkable gaps between 
myofibrils in many zones. As a result, neighboring myofibrils become compacted, losing their structural identity.
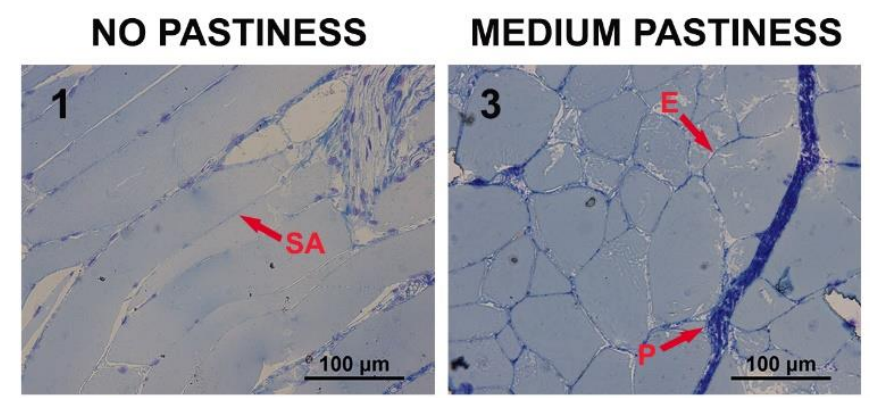

\section{HIGH PASTINESS}
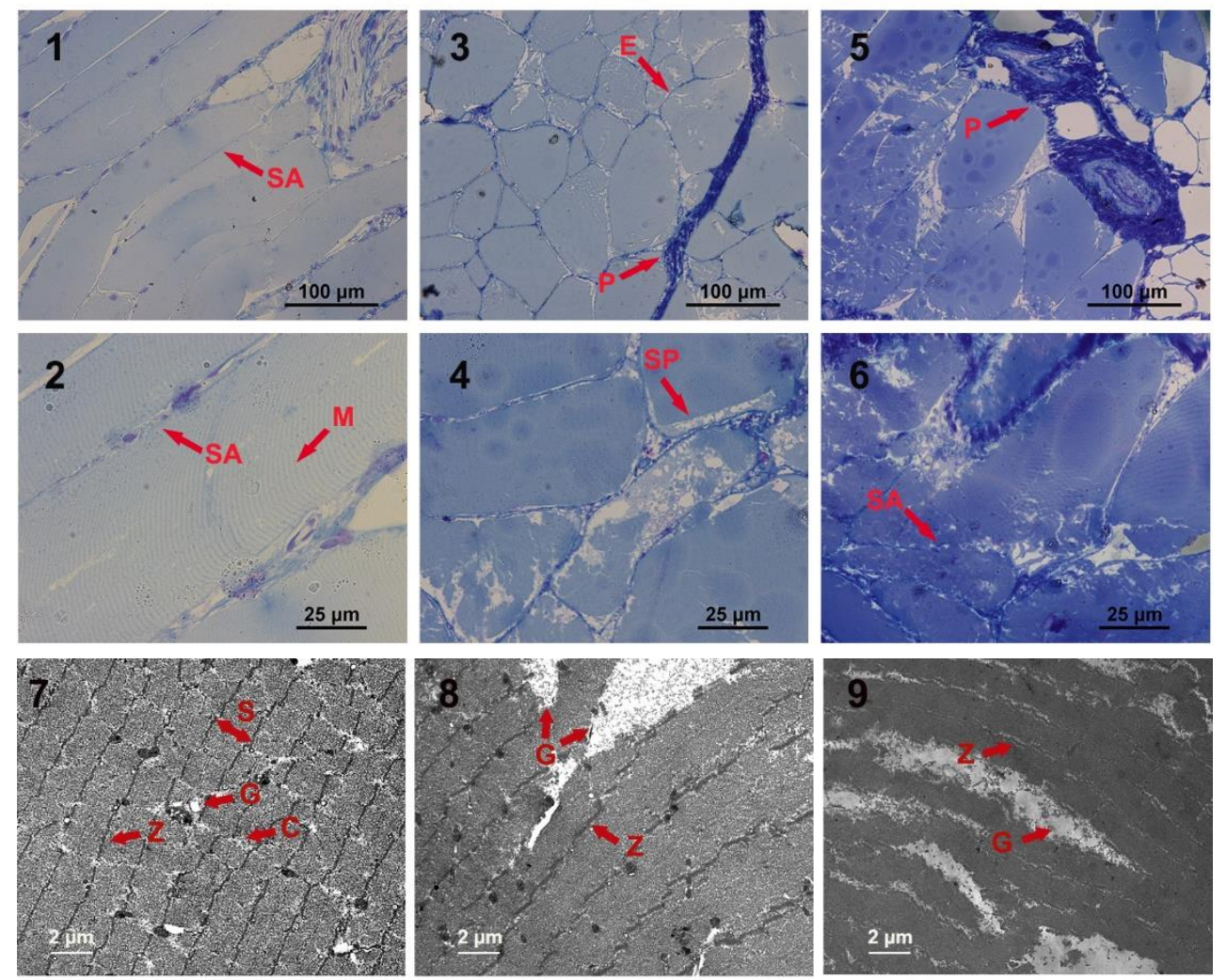

Figure 5. Light microscopy (1-6) and transmission electron microscopy (7-9) micrographs of Biceps femoris muscle tissue from dry-cured ham with different levels of pastiness (20x: 1, 3, 5; 60x: 2, 4, 6; 1200x: 7, 8, 9). C: Costamere; E: Endomysium; G: Gap; M: Myofibril; P: Perimysium; S: Sarcomere; SA: Sarcolemma; SP: Intracellular Space; Z: Z-line.

In general, BF muscle from dry-cured ham samples with medium and high levels of pastiness (Figure 5, 8-9) exhibits a high degree of damage compared to dry-cured ham without pastiness; this increases as the level of pastiness rises. In most cases, myofibrillar structural elements in muscle with medium and high levels of pastiness are repeatedly degraded and occasionally disappear, showing a merged protein structure. This indicates a high degree of proteolysis in pasty samples, steeper in samples with high levels of pastiness. Solute accumulation from the proteolysis can be appreciated in the gaps formed as a result of tissue disintegration. Zdisks are considerably degraded, surrounded by gaps, and disappear in many areas of samples with medium levels of pastiness; in samples with a high level of pastiness, there are no Z-disks in most of the tissue. The rest of the myofibrillar structural elements that can be observed in NP drycured ham, such as H-zone and costamere structures, cannot be appreciated in pasty samples, regardless of the level of pastiness. In addition, the development of pastiness seems to be 
characterized by an intense tissue degradation, the merging of myofibril structures and the appearance of large gaps, where material originating from an intense proteolysis of myofibrillar structural components is accumulated.

It could be concluded that, in pasty hams, proteolysis led to important structural changes in the muscle cells, such as myofibril degradation and gap formation, which caused ham textural changes (decrease in hardness and elasticity), as observed in section 3.3.

\subsection{Ultrasonic characterization of pastiness}

An ultrasonic non-destructive analysis was carried out in dry-cured ham BF muscle using the through-transmission mode. Two ultrasonic parameters were computed: velocity and attenuation. The ultrasonic velocity obtained for NP samples was $1723 \pm 2 \mathrm{~m} / \mathrm{s}$, which concurred with earlier findings for other dry-cured ham parts. In this sense, the ultrasonic velocity in Iberian dry-cured ham slices from the butt end and fore cushion was $1732 \pm 2$ and $1765 \pm 2 \mathrm{~m} / \mathrm{s}$, respectively (Corona et al., 2013a). The ultrasonic velocity was significantly $(\mathrm{p}<0.05)$ related to the moisture $(r=0.69)$ and salt contents (0.79), as illustrated in Figure 6 and already reported in literature. Thus, when working on raw hams, de Prados et al. (2015a) found that the higher the moisture content, the greater the ultrasonic velocity $(\mathrm{r}=0.95)$. As for the salt content, earlier literature reported that ultrasound velocity was closely related with the salt content in dry-cured ham $(r=0.730)$ (Fulladosa et al., 2015). Both the moisture and salt content could be related to ultrasonic velocity since the loss of water and the gain of soluble solids increased the bulk modulus and hence the velocity of the ultrasound. Likewise, ultrasonic velocity has been used previously to evaluate textural properties. As an example, Corona et al. (2013a) found that an increase in the hardness of lean and fatty tissue led to a rise in ultrasonic velocity. However, in the present study, there were found to be no significant ( $p>0.05$ ) differences between the velocity figures and the textural parameters. Thereby, as illustrated in Table 1, the different groups of pastiness showed similar ultrasonic velocities, which indicates that this parameter was not capable of characterizing this defect. 

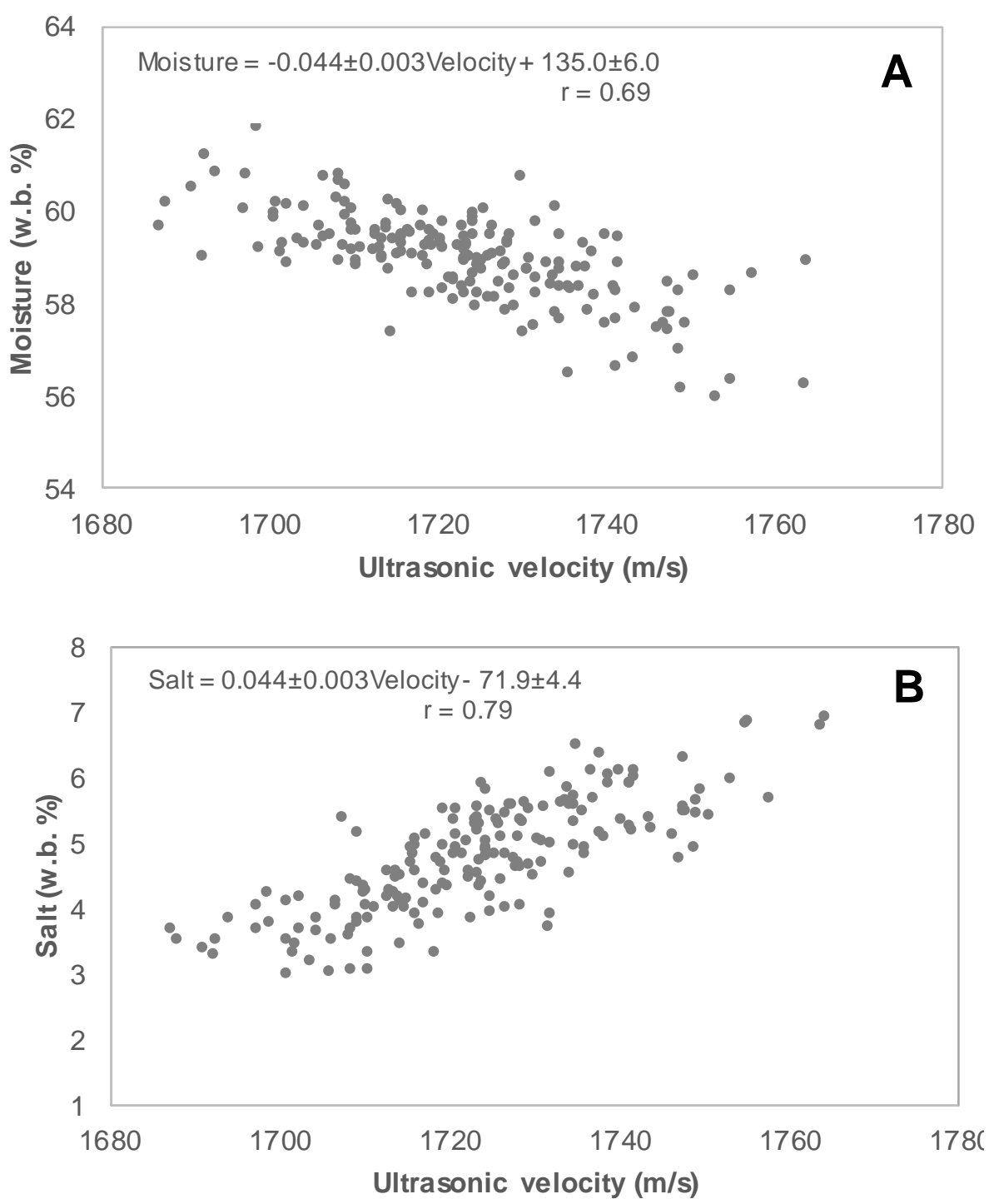

Figure 6. A: Relationship between ultrasonic velocity and moisture (A) and salt content (B) in slices of dry-cured ham.

As for the ultrasonic attenuation coefficient, an average figure of $43 \pm 1 \mathrm{~Np} / \mathrm{m}$ was found in NP samples (Table 1). To our knowledge, no previous attenuation coefficient data have been reported for dry-cured ham. For raw meat, Koch et al. (2011) computed a value of $12 \pm 3 \mathrm{~Np} / \mathrm{m}$, for porcine Longissimus muscle at $24 \mathrm{~h}$ post mortem. The greater attenuation value found for drycured ham could be due to the lower water content held in the samples of the present study. Neither the moisture nor the salt content were found to have any influence on the attenuation coefficient. However, this parameter was significantly $(\mathrm{p}<0.05)$ affected by the textural attributes, such as hardness, relaxation capacity and pastiness. The evaluation of changes in meat texture through ultrasonic attenuation has already been reported in the literature. Ayadi et al. (2007) established a good relationship ( $\mathrm{r}=-0.81)$ between attenuation and stress at $20 \%$ deformation during the ageing period of $\mathrm{BF}$ muscle from beef cattle: attenuation decreased due to the fact that during the onset of rigor-mortis, the rigidity of meat increases. In this study, the analysis of 
variance of the ultrasonic attenuation coefficient revealed significant differences $(p<0.05)$ between the different groups of pastiness (Table 1). Thus, the highest attenuation coefficient was found in HP samples $(48 \pm 2 \mathrm{~Np} / \mathrm{m})$. As regards NP ham, the greatest relative increase in the attenuation coefficient was found in the HP group (11.8\%), which was more than twice that of the MP samples (5.3\%). The fact that attenuation increased as the level of pastiness rose could be explained by the greater energy loss of the ultrasonic wave when passing through a highly viscous medium (HP sample) compared to a normal one (NP sample). Overall, relative changes in the attenuation coefficient regarding NP samples (MP: 5.3\%; HP: 11.8\%) were similar to the rest of the parameters measured (PI, $\mathrm{Y}_{2}$, and $\mathrm{Y}_{90}$ ) (Table 1). However, bigger changes were found for hardness, reaching percentages of 43.1 and $67.7 \%$ for MP and HP samples compared to NP ones, respectively. This indicates that the hardness parameter seems the most sensitive of the ones used in this study to any modification caused by pastiness.

Finally, a discriminant analysis was carried out with the parameters that showed statistical significance $(\mathrm{p}<0.05)$ between the three groups of pastiness. Thus, the classification functions obtained with PI, hardness, $\mathrm{Y}_{2}, \mathrm{Y}_{90}$ and attenuation coefficient parameters were able to classify $72 \%$ of the ham samples in the correct group of pastiness.

Based on the results obtained, using ultrasound technology to measure the ultrasonic attenuation coefficient could be a useful means of performing the non-destructive characterization of pastiness in dry-cured ham and, thereby, may help to distinguish between samples with different levels of pastiness.

\section{Conclusions}

Pastiness was developed in dry-cured ham over a wide range of salt and moisture contents. This reveals that, despite the marked influence of these factors on the development and intensity of pastiness, this defect could eventually appear in samples of high salt and low moisture contents. From the microstructural and ultrastructural study, it could be concluded that, due to the high proteolysis, pasty ham loses its structure, leading to a protein gel wherein the higher the level of pastiness, the greater the structural degradation. These changes in the dry-cured ham structure brought about softer textures and higher relaxation capacities compared to dry-cured ham without pastiness. Non-destructive ultrasonic measurements revealed that the more intense the level of pastiness, the greater the ultrasonic attenuation coefficient. In this sense, ultrasound could be a useful means of performing the non-destructive detection of commercial pasty dry-cured ham with different intensities of pastiness. 


\section{Acknowledgements}

The authors acknowledge the financial support from the "Spanish Ministerio de Economía y Competitividad (MINECO), Instituto Nacional de Investigación y Tecnología Agraria y Alimentaria (INIA)" in Spain, the European Regional Development Fund (ERDF 20142020) (Project RTA2013-00030-C03-02) and the PhD grant of M. Contreras from Universitat Politècnica de València.

\section{References}

AOAC. (1997). Official method 950.46. In Official Methods of Analysis (sixteenth ed.).

ASTM STP 758. (1981). American Society for Testing and Materials. Guidelines for the selection and training of sensory panel members.

Ayadi, A., Culioli, J., \& Abouelkaram, S. (2007). Sonoelasticity to monitor mechanical changes during rigor and ageing. Meat Science, 76, 321-326.

Benedini, R., Parolari, G., Toscani, T., \& Virgili, R. (2012). Sensory and texture properties of Italian typical dry-cured hams as related to maturation time and salt content. Meat Science, 90, 431-437.

Benedito, J., Carcel, J. A., Rossello, C., \& Mulet, A. (2001). Composition assessment of raw meat mixtures using ultrasonics. Meat Science, 57, 365-370.

Benedito, J., Carcel, J. A., Sanjuan, N., \& Mulet, A. (2000). Use of ultrasound to assess Cheddar cheese characteristics. Ultrasonics, 38, 727-730.

Corona, E., García-Pérez, J. V., Mulet, A., \& Benedito, J. (2013a). Ultrasonic assessment of textural changes in vacuum packaged sliced Iberian ham induced by high pressure treatment or cold storage. Meat Science, 95, 389-395.

Corona, E., García-Pérez, J. V., Ventanas, S., \& Benedito, J. J. (2013b). Ultrasonic characterization of the fat source and composition of formulated dry-cured meat products. Food Science and Technology International, 20, 275-285.

Corona, E., García-Pérez, J. V., Santacatalina, J. V., Ventanas, S., \& Benedito, J. (2014). Ultrasonic characterization of pork fat crystallization during cold storage. Journal of Food Science, 79.

de Prados, M., Fulladosa, E., Gou, P., Muñoz, I., Garcia-Perez, J. V., \& Benedito, J. (2015a). Non-destructive determination of fat content in green hams using ultrasound and X-rays. Meat Science, 104, 37-43.

de Prados, M., García-Pérez, J. V., \& Benedito, J. (2015b). Non-destructive salt content prediction in brined pork meat using ultrasound technology. Journal of Food Engineering, 154, 39-48. 
de Prados, M., Garcia-Perez, J. V., \& Benedito, J. (2016). Ultrasonic characterization and online monitoring of pork meat dry salting process. Food Control, 60, 646-655.

Desmond, E. (2006). Reducing salt: A challenge for the meat industry. Meat Science, 74, 188196.

Dwyer, C., Mullen, A.M., Allen, P., Buckin, V. (2001). Anisotropy of ultrasonic velocity as a method of tracking postmortem ageing in beef. Proceedings 47th ICoMST, 4, 250.

Fulladosa, E., Austrich, A., Muñoz, I., Guerrero, L., Benedito, J., Lorenzo, J. M., \& Gou, P. (2018). Texture characterization of dry-cured ham using multi energy X-ray analysis. Food Control, 89, 46-53.

Fulladosa, E., De Prados, M., García-Perez, J. V., Benedito, J., Muñoz, I., Arnau, J., \& Gou, P. (2015). X-ray absorptiometry and ultrasound technologies for non-destructive compositional analysis of dry-cured ham. Journal of Food Engineering, 155, 62-68.

Fulladosa, E., Rubio-Celorio, M., Skytte, J. L., Muñoz, I., \& Picouet, P. (2017). Laser-light backscattering response to water content and proteolysis in dry-cured ham. Food Control, $77,235-242$.

Garcia-Garrido, J. A., Quiles-Zafra, R., Tapiador, J., \& Luque De Castro, M. D. (1999). Sensory and analytical properties of Spanish dry-cured ham of normal and defective texture. Food Chemistry, 67, 423-427.

García-Rey, R. M., García-Garrido, J. A., Quiles-Zafra, R., Tapiador, J., \& Luque de Castro, M. D. (2004). Relationship between $\mathrm{pH}$ before salting and dry-cured ham quality. Meat Science, $67,625-632$.

Gou, P., Morales, R., Serra, X., Guàrdia, M. D., \& Arnau, J. (2008). Effect of a 10-day ageing at $30{ }^{\circ} \mathrm{C}$ on the texture of dry-cured hams processed at temperatures up to $18{ }^{\circ} \mathrm{C}$ in relation to raw meat $\mathrm{pH}$ and salting time. Meat Science, 80, 1333-1339.

Harkouss, R., Astruc, T., Lebert, A., Gatellier, P., Loison, O., Safa, H., Portanguen, S., Parafita, E., \& Mirade, P. S. (2015). Quantitative study of the relationships among proteolysis, lipid oxidation, structure and texture throughout the dry-cured ham process. Food Chemistry, $166,522-530$.

Koch, T., Lakshmanan, S., Brand, S., Wicke, M., Raum, K., \& Mörlein, D. (2011). Ultrasound velocity and attenuation of porcine soft tissues with respect to structure and composition: I. Muscle. Meat Science, 88, 51-58.

Larrea, V., Pérez-Munuera, I., Hernando, I., Quiles, A., Llorca, E., \& Lluch, M. A. (2007). Microstructural changes in Teruel dry-cured ham during processing. Meat Science, 76, 574 582. 
Llull, P., Simal, S., Benedito, J., \& Rosselló, C. (2002). Evaluation of textural properties of a meat-based product (sobrassada) using ultrasonic techniques. Journal of Food Engineering, $53,279-285$.

López-Pedrouso, M., Pérez-Santaescolástica, C., Franco, D., Fulladosa, E., Carballo, J., Zapata, C., \& Lorenzo, J. M. (2018). Comparative proteomic profiling of myofibrillar proteins in dry-cured ham with different proteolysis indices and adhesiveness. Food Chemistry, 244, $238-245$.

Morales, R., Guerrero, L., Serra, X., \& Gou, P. (2007a). Instrumental evaluation of defective texture in dry-cured hams. Meat Science, 76, 536-542.

Morales, R., Serra, X., Guerrero, L., \& Gou, P. (2007b). Softness in dry-cured porcine biceps femoris muscles in relation to meat quality characteristics and processing conditions. Meat Science, 77, 662-669.

Niñoles, L., Mulet, A., Ventanas, S., \& Benedito, J. (2011). Ultrasonic characterisation of B. femoris from Iberian pigs of different genetics and feeding systems. Meat Science, 89, 174180.

Nowak, K. W., Markowski, M., \& Daszkiewicz, T. (2015). Ultrasonic determination of mechanical properties of meat products. Journal of Food Engineering, 147, 49-55.

Parolari, G., Virgili, R., \& Schivazappa, C. (1994). Relationship between cathepsin B activity and compositional parameters in dry-cured hams of normal and defective texture. Meat Science, $38,117-122$.

Pérez-Santaescolástica, C., Carballo, J., Fulladosa, E., Garcia-Perez, J. V., Benedito, J., \& Lorenzo, J. M. (2018). Effect of proteolysis index level on instrumental adhesiveness, free amino acids content and volatile compounds profile of dry-cured ham. Food Research International, 107, 559-566.

Ruiz-Ramírez, J., Arnau, J., Serra, X., \& Gou, P. (2006). Effect of pH24, NaCl content and proteolysis index on the relationship between water content and texture parameters in biceps femoris and semimembranosus muscles in dry-cured ham. Meat Science, 72, 185-194.

Schivazappa, C., Degni, M., Nanni Costa, L., Russo, V., Buttazzoni, L., \& Virgili, R. (2002). Analysis of raw meat to predict proteolysis in Parma ham. Meat Science, 60, 77-83.

Serra, X., Ruiz-Ramírez, J., Arnau, J., \& Gou, P. (2005). Texture parameters of dry-cured ham $\mathrm{m}$. biceps femoris samples dried at different levels as a function of water activity and water content. Meat Science, 69, 249-254.

Simal, S., Benedito, J., Clemente, G., Femenia, A., \& Rosselló, C. (2003). Ultrasonic determination of the composition of a meat-based product. Journal of Food Engineering, 
$58,253-257$

Swatland, H. J. (2001). Elastic deformation in probe measurements on beef carcasses. Journal of Muscle Foods, 12, 97-105.

Virgili, R., Parolari, G., Schivazappa, C., Bordini, C. S., \& Borri, M. (1995). Sensory and texture quality of dry-cured ham as affected by endogenous cathepsin B activity and muscle composition. Journal of Food Science, 60, 1183-1186. 




\title{
Development of air-coupled ultrasonic techniques to characterize dry-cured ham texture
}

\author{
Marina Contreras ${ }^{1}$, Jose Benedito ${ }^{1}$, Melvin Holmes ${ }^{2}$, Megan J.W. Povey ${ }^{2}$, \\ Jose Vicente Garcia-Perez ${ }^{1}$
}

${ }^{1}$ Grupo de Análisis y Simulación de Procesos Agroalimentarios (ASPA). Departamento de Tecnología de Alimentos. Universitat Politècnica de València. Camí de Vera s/n, Valencia (46022), Spain.

${ }^{2}$ School of Food Science and Nutrition. University of Leeds. Woodhouse Lane (LS2 9JT), Leeds. 



\section{Development of air-coupled ultrasonic techniques to characterize dry-cured ham texture}

\section{Introduction}

The use of conventional ultrasound technologies has been demonstrated to be a feasible technique to assess non-destructively food composition and texture in a wide variety of foodstuffs (Benedito et al., 2000; Llull et al., 2002; Valente et al., 2013) since the ultrasonic waves are affected by the medium in which are propagated. Thereby, the properties of the medium can be inferred from the ultrasonic parameters. In particular, in the meat sector, the composition (salt, water or fat content) of loin and ham (Corona et al., 2014; de Prados et al., 2017) and the pastiness level in dry-cured ham (Contreras et al., 2020) were satisfactorily assessed by means of contact ultrasound. Notwithstanding, conventional ultrasound techniques require the direct contact between the transducers and the product's surface and hence, its invasion, leading to possible surface modification or damage as well as cross-contamination between consecutive samples. In order to solve these drawbacks, a further step can be achieved with the use of air-coupled ultrasound. One of the main advantages that present air-coupled ultrasound compared to contact ultrasound is its non-invasive character. The transducers are static, without being in contact with the sample to be measured, and located at a certain distance of the product (in the range of 50$100 \mathrm{~mm}$ ). Thus, all the moving parts that are used for the transducer coupling in contact ultrasound techniques are not necessary, which makes easier its implementation in further industrial applications with food items moving on conveyor belts. This configuration avoids the compression of the sample and hence, a possible damage. Furthermore, the lack of coupling between the transducer and the product to be measured prevents the cross-contamination between samples. The transducers configuration previously mentioned leads to the second main advantage since it allows a shorter time of scanning and hence, the measurement is faster. Notwithstanding, air-coupled ultrasound implies the pass of the ultrasonic waves through the air until reaching the sample, in addition to the travel of the wave through the sample. The lower impedance of the air compared to that of the ultrasonic transducer makes difficult the propagation of ultrasonic waves to that medium. Thus, achieving an efficient ultrasonic energy transfer from the transducer to the sample is of paramount importance. To overcome this problem, an efficient approach is based on the use of active and passive multilayer materials added coupled to the piezoelectric transducers in order to create a gradual decrease in the acoustic impedance and thus, minimizing the energy loss by reflection on the air interface (Gómez Álvarez-Arenas., 2004; Jayaraman et al., 2007). This ultrasonic configuration allows a larger performance due to the acoustic impedance of the emitter is progressively decreased until being close to that of the air, which improves the energy transferred into the air medium (Gómez Álvarez-Arenas, 2013). In addition to this, a second energy barrier in the ultrasonic propagation has to be considered due to the large impedance 
difference between the air and food interface, which again increases the loss of energy by reflection and reduces the amount of energy transmitted into the product.

Previous literature assessed the viability of using non-contact ultrasound for characterizing dry-cured meat products (dry-cured ham) (Corona et al., 2013c), claiming that the technology could be feasible. In this thesis, different air-coupled ultrasonic techniques have been developed to be used in both slices and whole dry-cured hams. The implementation of these techniques could contribute to the achievement of a non-invasive characterization, allowing the identification of relevant textural properties in dry-cured ham and the pre-sale grading depending on its characteristics. The different techniques are described according to its operation mode as follows.

\section{Air-coupled ultrasound in through-transmission mode}

Air-coupled ultrasound was used to measure dry-cured ham slices (10 mm thick) and whole pieces (up to $120 \mathrm{~mm}$ thick). Samples were measured in through-transmission mode following the configuration shown in Figure 1. The transducers were confronted and aligned and the ham slice was placed between both transducers. The distance between the transducer and the product's surface was minimized but, in every case, the presence of echoes from the product surface to the receiver transducer, which could be time-coupled in the signal, had to be avoided. Thereby, an average distance of $50 \mathrm{~mm}$ was employed. Except for the transducers, the experimental set-up used regarding the pulser-receiver and oscilloscope devices was identical to the one described by Contreras et al. (2020). Air-coupled transducers were provided by the USBioMat Laboratory (ITEFI-CSIC, Madrid, Spain). The frequency of the transducers was $250 \mathrm{kHz}$ and the diameter $25 \mathrm{~mm}$. The operation mode was in normal incidence; where the ultrasonic signal traveled from the emitter transducer to the ham sample through the air, crossed the ham and again traveled through the air until reaching the receiver transducer (Figure 1). 


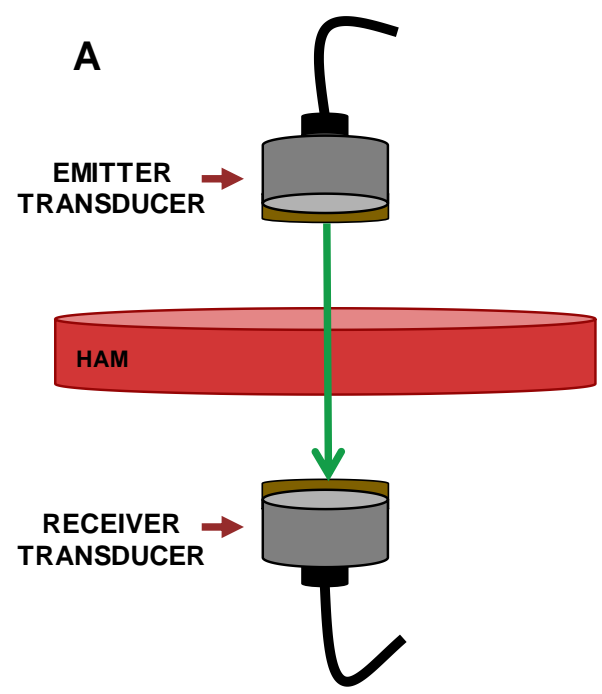

B

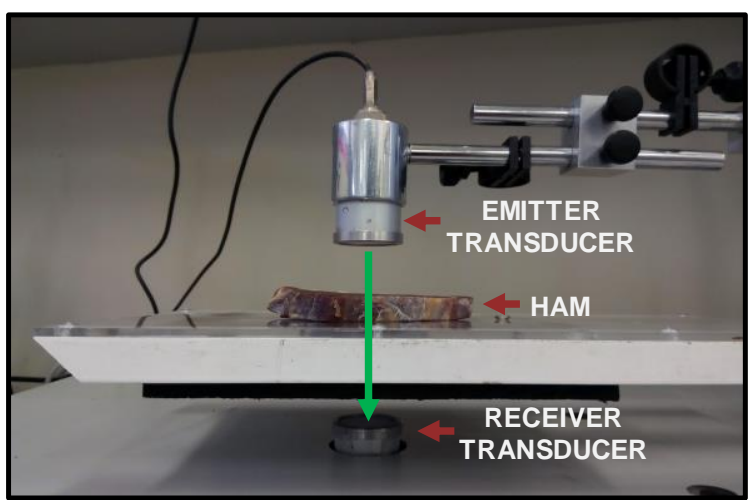

Figure 1. A: Experimental configuration of the air-coupled transducers in through-transmission mode; B: Air-coupled transducers in through-transmission mode measuring a dry-cured ham slice.

As for whole pieces, Figure 2 shows the ultrasonic signal recorded between both transducers with (ham piece) and without the sample (reference); the latter is used as the reference signal and is of paramount importance for the further calculation of ultrasonic parameters. It could be appreciated the higher amplitude of the reference signal since the absence of sample makes more energy come into the receiver transducer. The energy loss of the ham signal arises from the reflection on the ham-air interfaces as well as the signal attenuation in the ham. Furthermore, it could be appreciated that the ham signal arrives first compared to the reference signal due to the higher ultrasonic velocity in the ham $( \pm 1750 \mathrm{~m} / \mathrm{s})$ compared to the air $( \pm 343 \mathrm{~m} / \mathrm{s})$.

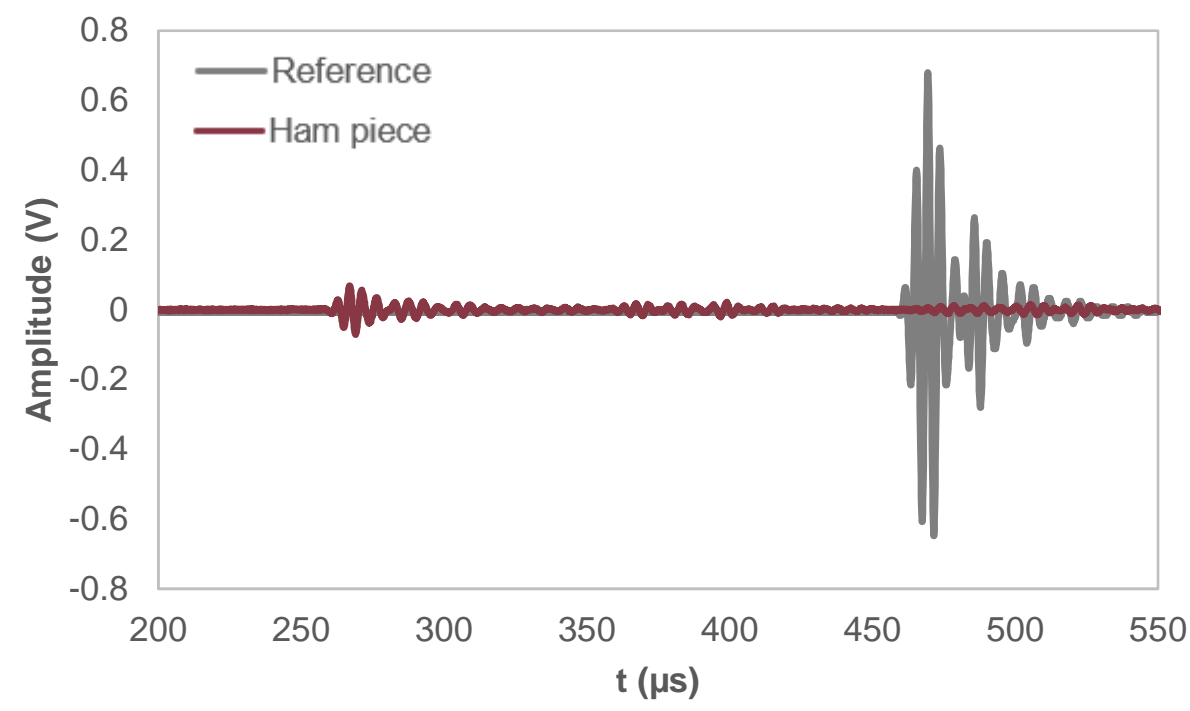

Figure 2. Reference and dry-cured ham piece ultrasonic signals obtained by air-coupled ultrasound in through-transmission mode. 
The reference signal has to be obtained in the same time-frame than the one crossing the sample due to the air conditions, such as the temperature or small turbulences, can create large modifications on its properties and hence, the features of the ultrasound travelling through this medium. In a practical point of view, the reference signal has to be acquired immediately before or after the measurement of the sample. Gómez Álvarez-Arenas et al. (2009) described how conjugating the reference and the sample signal, the ultrasonic velocity $(V(\mathrm{~m} / \mathrm{s})$, Eq. 1$)$ and the insertion loss (IL (dB), Eq. 2) can be assessed. IL computes how the energy is distributed in the frequency spectrum:

$$
\begin{aligned}
& V=\frac{h}{h / V_{f}-\Delta T O F} \\
& I L=20 \log \left(A / A_{0}\right)
\end{aligned}
$$

where $h$ is the thickness of the sample $(\mathrm{m}), V_{f}$ is the ultrasound velocity in the air $(\mathrm{m} / \mathrm{s}), \triangle T O F$ is the difference of the time of flight (s) between the sample and the reference, which could be estimated according to the methods described by Garcia-Perez et al. (2019), and $A$ and $A_{0}$ are the amplitude of the Fast Fourier Transform (FFT) of the ham and reference signals, respectively.

Figure 3 shows the average of the IL for 5 measurements carried in a whole ham piece. Experimental points follow a linear relationship and its slope determines the loss of energy (dB) per frequency unit $(\mathrm{MHz})$, which is a characteristic property of a material intimately linked to the attenuation coefficient and independent of the travelling distance of the ultrasonic wave (sample thickness). By contrast, the y-intercept of the linear relationship is dependent on the thickness.

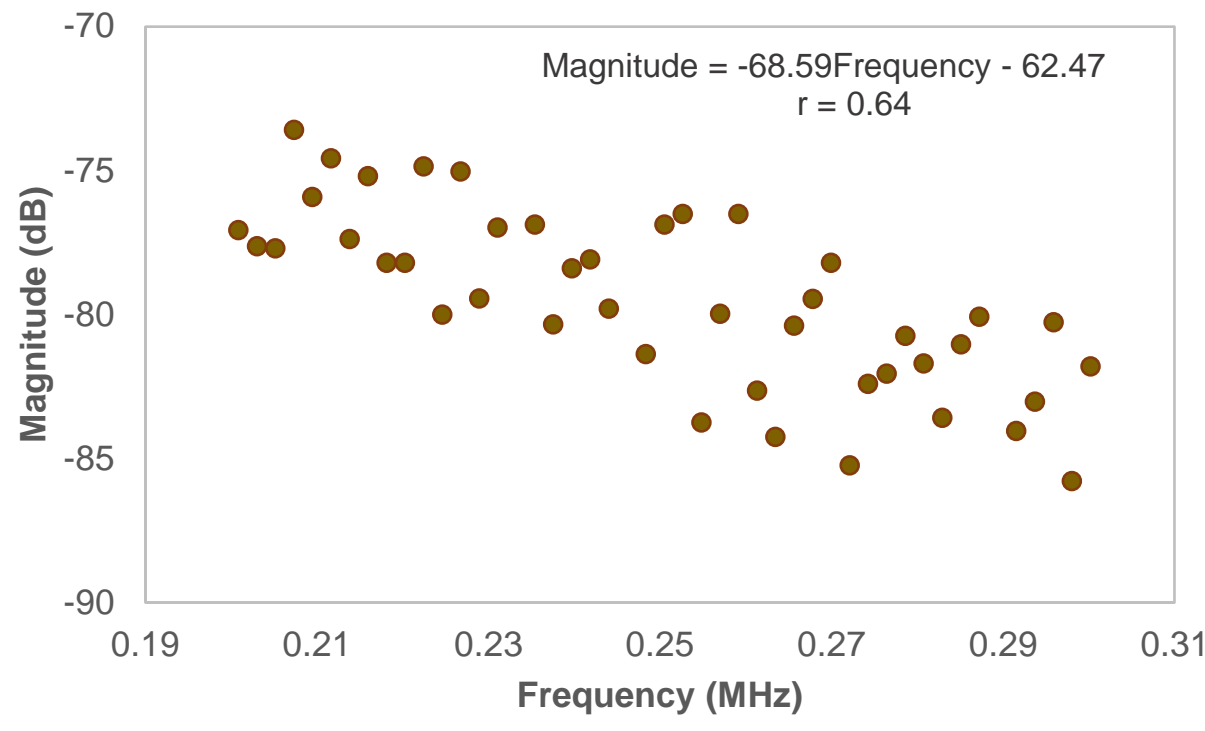

Figure 3. Frequency spectrum of the insertion loss of an ultrasonic wave passing through a piece of ham (87 $\mathbf{m m}$ thick). 
The measuring in the through-transmission mode of a flat sample with a particular thickness can provoke the vibration of the sample, generating resonances that are manifested in the ultrasonic signal acquired. The resonance analysis from the insertion loss (Figure 4) and the identification of the resonance frequency (Eq. 3) can lead to a joint estimation of the sample thickness and the ultrasonic velocity in the ham by conjugating Eq. 1 and 3:

$$
f_{n}=n V /(2 h), \quad n=1,2,3 \ldots
$$

where $f_{n}$ is the resonance frequency of the sample (MHz), $n$ is the order of the resonance, $V$ is the ultrasound velocity $(\mathrm{m} / \mathrm{s})$ in the sample and $h$ is the thickness $(\mathrm{m})$ of the sample.

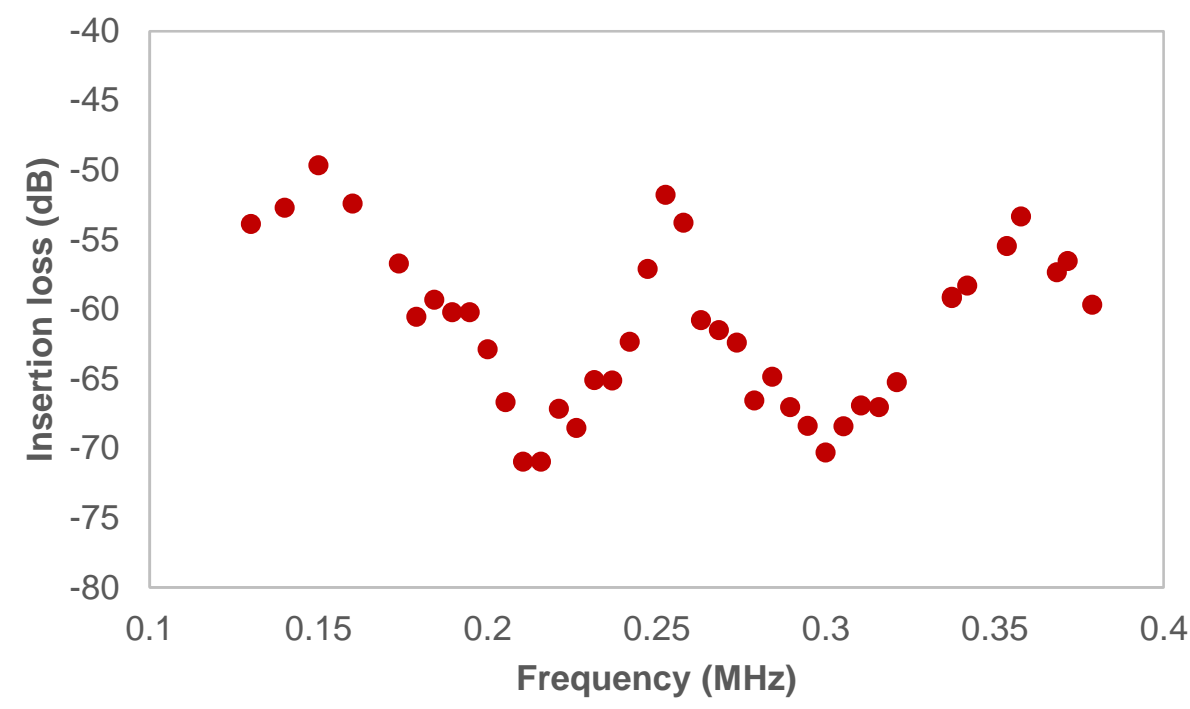

Figure 4. Frequency spectrum of the insertion loss of an ultrasonic wave passing through a slice of ham (10 mm thick).

\section{Air-coupled ultrasound in pulse-echo mode}

The research internship conducted during this $\mathrm{PhD}$ in the University of Leeds was carried out with the purpose of implementing another air-coupled ultrasonic technique for the detection of dry-cured ham with textural defects: the pulse-echo mode. The experiments were performed in the School of Food Science and Nutrition under the supervision of Professors Megan W.J. Povey and Melvin Holmes, for being a pioneering group on the use of this technique in food materials (Watson et al., $2012 \&$ 2014).

Figure 5 shows the layout and the set-up used for the air-coupled ultrasound technique in pulse-echo mode using 2 transducers (Ultran, USA), one as emitter and one as receiver. The 
frequency of the transducers was $140 \mathrm{kHz}$ and the diameter $25 \mathrm{~mm}$. Using the pulse-echo mode and tuning the angle of inclination, different experiments can be performed.

A

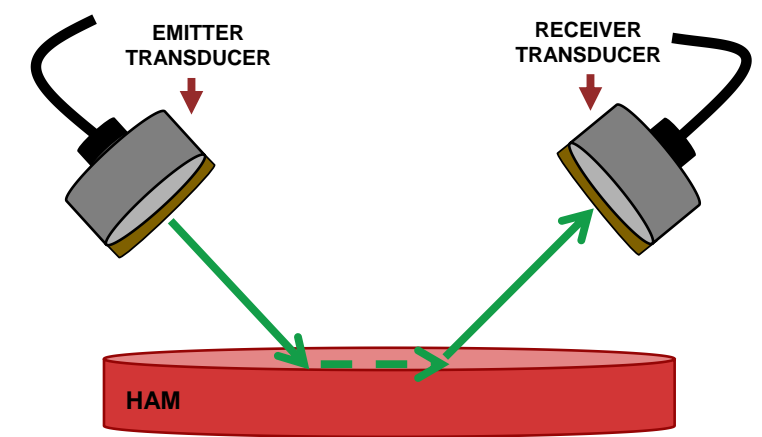

B

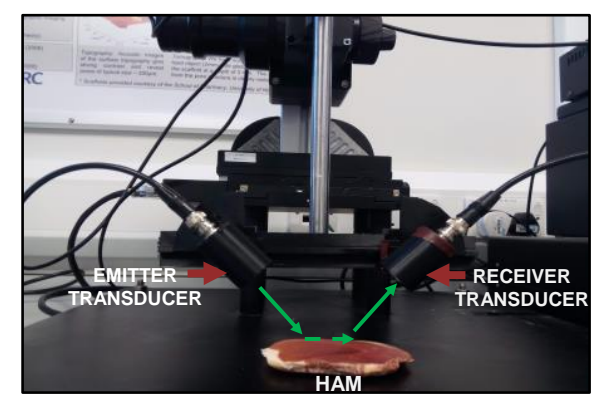

Figure 5. A: Experimental configuration of the air-coupled transducers in pulse-echo mode; B: Aircoupled transducers in pulse-echo mode measuring a dry-cured ham slice.

When an ultrasonic measurement is performed with the transducers-triangle configuration aforementioned, a longitudinal ultrasonic signal travels through the air from the emitter transducer and arrives into the sample. A large portion of the ultrasonic energy is reflected, but some energy is refracted and penetrates into the ham. The energy refracted depends on the incident angle of the ultrasound wave. There exist two critical angles that depend on the material where the ultrasonic wave travels through. Before reaching the first critical angle, the longitudinal wave traveling through the air penetrates also into the ham; however, when the first critical angle is achieved, the longitudinal signal traveling through the air is converted into a surface longitudinal wave (creep wave) and it just travels through the ham surface. Once the first critical angle is overcome, the longitudinal signal traveling through the air is converted into a shear wave inside the ham. Beyond the second critical angle, no kind of ultrasonic wave is capable of propagating into the ham.

Snell's law can be applied to calculate the angle of the longitudinal signal refracted, which will travel through the ham $\left(\theta_{21}\right)$ (Figure 6) (Eq. 4):

$$
\frac{\operatorname{sen} \theta_{1}}{V_{\text {air }}}=\frac{\operatorname{sen} \theta_{2 l}}{V_{h l}}
$$

where $\theta_{1}$ is the angle $\left(^{\circ}\right)$ of the emitter transducer pointing to the sample, $V_{\text {air }}$ is the velocity of sound in air $(343 \mathrm{~m} / \mathrm{s})$ and $V_{h l}$ is the longitudinal velocity of sound in the ham (value from Corona et al. (2013a): $1750 \mathrm{~m} / \mathrm{s})$. 


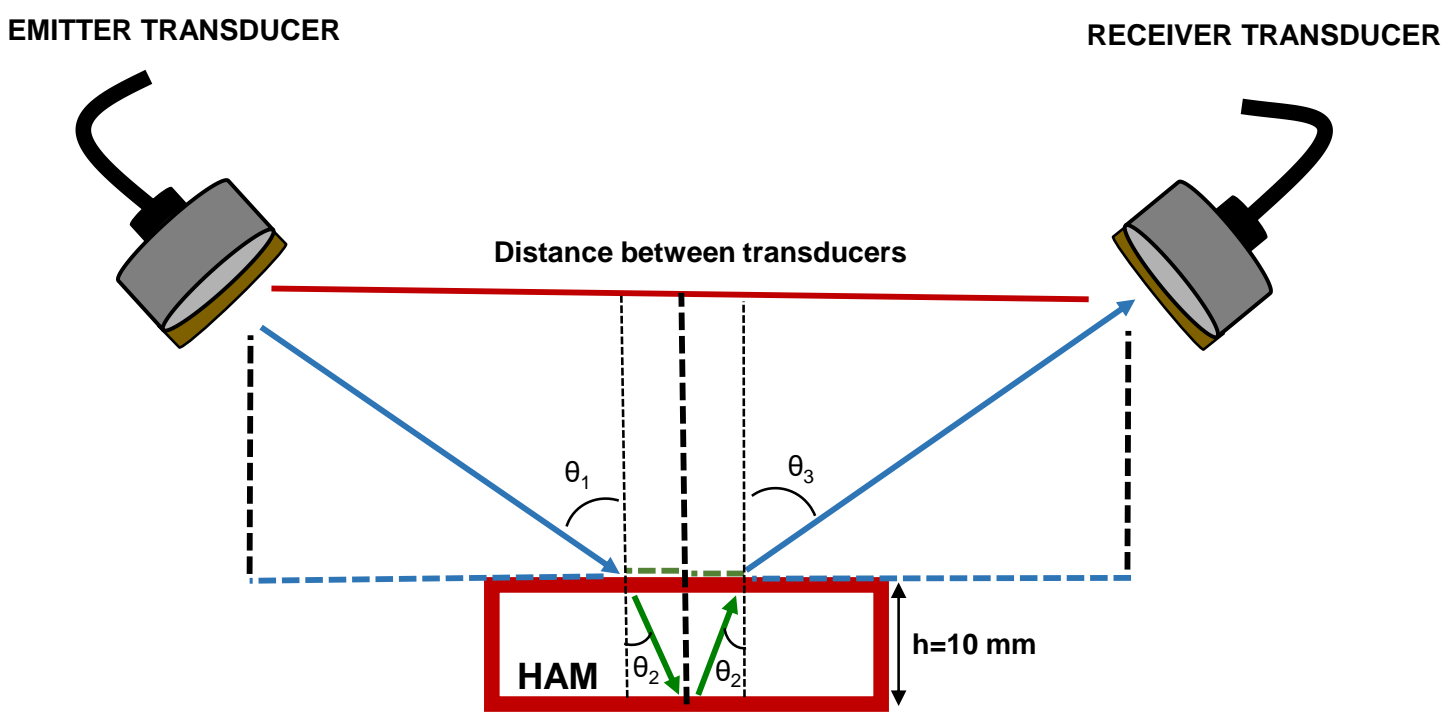

Figure 6. Angles of the imaginary triangle formed between the transducers and the ham sample in the pulse-echo mode.

The large difference of acoustic velocity between the air and the ham made that the first critical angle for the longitudinal waves to travel into the ham was $11.3^{\circ}\left(\theta_{1}\right)$. If this critical angle $\left(\theta_{1}\right)$ is achieved, the longitudinal wave bumping into the sample is converted into a creep wave that travels through the surface of the sample. Beyond the first critical angle $\left(11.3^{\circ}\right)$, only the shear waves could propagate into the ham. However, based on previous literature (Gómez Álvarez-Arenas et al., 2009), shear waves are negligible in dry-cured ham probably because the attenuation of this wave is too large. Therefore, most of the energy captured by the receiver transducer (Figure 6) must be the longitudinal wave reflected on the ham surface. Thus, a pitch and catch experiment (Fariñas, 2016) was performed in order to determine the position that allows to receive most of the reflected energy. This technique consists on leaving fix the emitter transducer and approaching the receiver transducer in order to scan a larger area. The angle of inclination of both the emitter and receiver transducers pointing the sample was fixed in $45^{\circ}$. The receiver transducer was $140 \mathrm{~mm}$ far from the emitter transducer and its displacement was of 5 $\mathrm{mm}$ until reaching a minimum distance between transducers of $60 \mathrm{~mm}$. In each position, an ultrasonic measurement was taken. The maximum amplitude of the signal was assessed and plotted according to the transducers distance (Figure 7). The scanning revealed a maximum peak, corresponding with a distance of $105 \mathrm{~mm}$ between transducers, where the maximum ultrasonic energy was obtained. Comparison of the maximum energy (Figure 7) for different hams could contribute to estimate the acoustic impedance of the ham samples and consequently to nondestructively determine the ultrasonic velocity in the hams. 


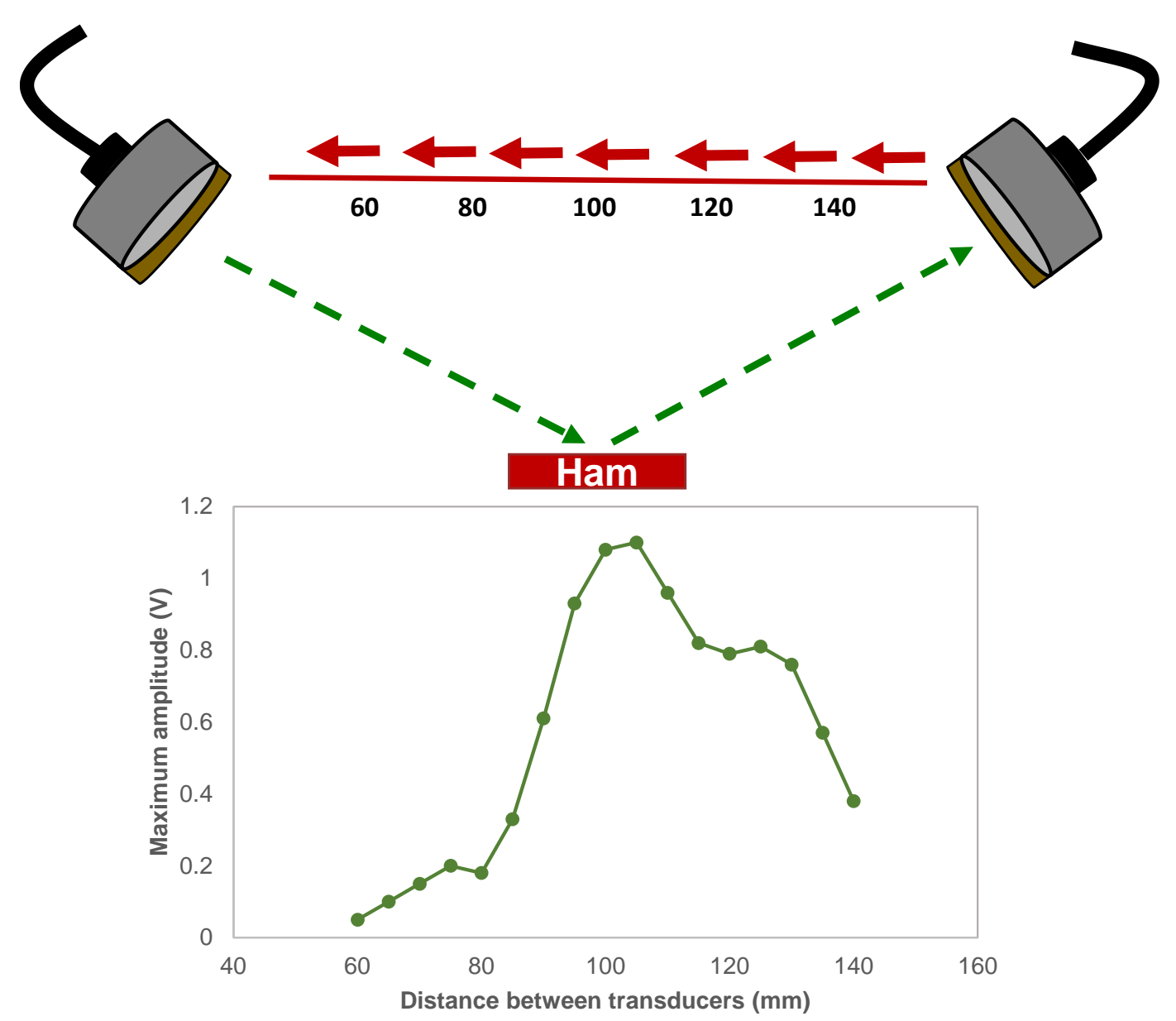

Figure 7. Maximum signal amplitude (V) from a slice of ham scanned in pulse-echo at different distances between transducers (from 60 to $140 \mathrm{~mm}$ ).

\section{Conclusions and remarks}

The development of the air-coupled ultrasonic techniques in the frame of the $\mathrm{PhD}$ were time delayed regarding the research project in which the thesis was performed (RTA2013-00030C03-02). Thus, the feasibility of these technologies to characterize samples with different levels of pastiness could not be assessed due to the high relevance of the samples since significantly differentiated texture ham samples could not be obtained for an accurate assessment. Therefore, the air-coupled ultrasonic study was focused on the development of the experimental set-ups as well as the signal analysis methodologies. The advantages of air-coupled ultrasound already depicted in the introduction section highlight the great potential of this technique for industrial applications in the frame of the industry 4.0.

As regards the characterization of dry-cured ham and specifically, the texture defect, the first potential application of this technique could be the online monitoring of ham slices to detect the ones presenting the pastiness defect in a non-invasive and faster way compared to contact 
ultrasound. Furthermore, due to the advantageous characteristics of air-coupled ultrasound, scans of entire samples could be performed and image analysis techniques implemented. This would allow the possibility to discard, reclassify or correct the ham before its commercialization. Moreover, this technique could be developed and adapted to solve the coupling problems between the transducers and samples with irregular surfaces, such in the case of whole hams. This would enhance their inspection with the aim of detecting and classifying them according to their pastiness level before being sliced.

\section{References}

Benedito, J., Carcel, J., Clemente, G., \& Mulet, A. (2000). Cheese maturity assessment using ultrasonics. Journal of Dairy Science, 83, 248-254.

Contreras, M., Benedito, J., Quiles, A., Lorenzo, J. M., Fulladosa, E., Gou, P., \& Garcia-Perez, J. V. (2020). Assessing the textural defect of pastiness in dry-cured pork ham using chemical, microstructural, textural and ultrasonic analyses. Journal of Food Engineering, 265, 109690.

Corona, E., García-Pérez, J. V., Mulet, A., \& Benedito, J. (2013a). Ultrasonic assessment of textural changes in vacuum packaged sliced Iberian ham induced by high pressure treatment or cold storage. Meat Science, 95, 389-395.

Corona, E., Garcia-Perez, J. V., Gomez Alvarez-Arenas, T. E., Watson, N., Povey, M. J. W., \& Benedito, J. (2013c). Advances in the ultrasound characterization of dry-cured meat products. Journal of Food Engineering, 119, 464-470.

Corona, E., García-Pérez, J. V., Santacatalina, J. V., Ventanas, S., \& Benedito, J. (2014). Ultrasonic characterization of pork fat crystallization during cold storage. Journal of Food Science, 79, E828-E838.

de Prados, M., Garcia-Perez, J. V., \& Benedito, J. (2017). Non-invasive ultrasonic technology for continuous monitoring of pork loin and ham dry salting. Meat Science, 128, 8-14.

Fariñas, M. D. (2016). Espectroscopía ultrasónica resonante sin contacto y su aplicación al estudio de tejidos vegetales en estructura multicapa. PhD Thesis. Universidad Politécnica de Madrid.

Garcia-Perez, J. V., de Prados, M., Martinez, G., Gomez Alvarez-Arenas, T. E., \& Benedito, J. (2019). Ultrasonic online monitoring of the ham salting process. Methods for signal 
analysis: Time of flight calculation. Journal of Food Engineering, 263, 87-95.

Gómez Álvarez-Arenas T.E. (2004). Acoustic Impedance Matching of Piezoelectric Transducers to the Air. IEEE Trans Ultrason Ferroelectr Freq Control., 51, 624-633.

Gómez Álvarez-Arenas, T.E. (2013). Air-coupled piezoelectric transducers with active polypropylene foam matching layers. Sensors, 13, 5996-6013.

Gómez Álvarez-Arenas, T.E., Benedito, J., \& Corona, E. (2009). Non-contact ultrasonic assessment of the properties of vacuum-packaged dry-cured ham. Proceedings - IEEE Ultrasonics Symposium, 2541-2544.

Jayaraman, S., Pellkofer, D., Lucas, I., Bezdek, M., \& Tittmann, B. (2007). Progress in aircoupled ultrasound. Proceedings of SPIE - The International Society for Optical Engineering, 6531, 65310.

Llull, P., Simal, S., Benedito, J., \& Rosselló, C. (2002). Evaluation of textural properties of a meat-based product (sobrassada) using ultrasonic techniques. Journal of Food Engineering, $53,279-285$.

Valente, M., Prades, A., \& Laux, D. (2013). Potential use of physical measurements including ultrasound for a better mango fruit quality characterization. Journal of Food Engineering, $116,57-64$.

Watson, N., Hazlehurst, T., Povey, M., Vieira, J., Sundara, R., \& Sandoz, J. P. (2014). Can airborne ultrasound monitor bubble size in chocolate? Journal of Physics: Conference Series, 498, 1-13.

Watson, N., Povey, M., Corona, E., Benedito, J., \& Parker, N. (2012). Acoustic microscopy in the food industry. IOP Conference Series: Materials Science and Engineering, 42, 1-4. 




\section{CHAPTER 2}

\section{Ham Texture Improvement}



Innovative Food Science and Emerging Technologies, 2018, 50, 94-101. Accelerated mild heating of dry-cured ham by
applying power ultrasound in a liquid medium

Marina Contreras, Jose Benedito, Jose Bon, Jose Vicente Garcia-Perez

Grupo de Análisis y Simulación de Procesos Agroalimentarios (ASPA). Departamento de Tecnología de Alimentos. Universitat Politècnica de València. Camí de Vera s/n, Valencia (46022), Spain. 



\title{
Accelerated mild heating of dry-cured ham by applying power ultrasound in a liquid medium
}

\begin{abstract}
Mild thermal treatments could be considered a feasible technique with which to improve the texture of dry-cured ham. This study explores the feasibility of using power ultrasound $(\mathrm{PuS})$ to intensify heat transfer during the mild thermal treatment of dry-cured ham immersed in a liquid medium. For that purpose, a temperature controlled ultrasonic bath was used to avoid the water temperature rise due to cavitation during ultrasonic application, which could mask the actual effect of ultrasound in heat transport mechanisms. Experiments were carried out using dry-cured ham slices (thickness $2 \mathrm{~cm}$ ), which were heated at different temperatures $(40,45,50$ ${ }^{\circ} \mathrm{C}$ ) with (PuS) and without (conventional mechanical stirring, CV) ultrasonic assistance. Temperature was monitored in the two main muscles of the ham (Biceps femoris and Semimembranosus) and in different positions of the slice. A model that considered heat transfer entirely controlled by conduction was chosen for describing heating kinetics and quantify the influence of temperature and ultrasonic application in the apparent thermal diffusivity.

The heat conduction model proposed was adequate to describe both $\mathrm{CV}$ and PuS heating kinetics (VAR >98.6\%). Ultrasound application sped up the heat transfer by increasing the apparent thermal diffusivity up to $51 \%$, but the higher the temperature, the lower the ultrasonic intensification. The apparent thermal diffusivities identified for the slices were satisfactorily validated (VAR> 98.4\%) in independent experiments with ham cylinders. Therefore, PuS could be considered as an effective technology for the purposes of accelerating the heat transfer, thus shortening the heating time of dry-cured ham slices immersed in a liquid medium.
\end{abstract}

Keywords: dry-cured ham, heat transfer, thermal treatment, ultrasound, conduction, apparent thermal diffusivity. 


\section{Introduction}

Cured meat products requiring a long period of curing sometimes present defective texture at the end of the processing. Especially in dry-cured ham, some intrinsic factors like low pH (García-Rey et al., 2004), high water content (Ruiz-Ramírez et al., 2006) or high proteolytic activity (Garcia-Garrido et al., 1999) as well as processing factors like the use of low salt concentrations (Ruiz-Ramírez et al., 2006) or the use of excessive high temperatures during curing (Arnau et al., 1997) can provoke soft and pasty textures. These texture defects diminish the quality of the final product (Schivazappa et al., 2002), causing rejection by the consumer. In this context, some authors have addressed different ways of improving defective textures at the end of the elaboration process of dry-cured ham. Garcia-Gil et al. (2014) stated that dry-cured ham slices subjected to high pressure treatment (500 MPa) tended to be harder than control ones, while Fulladosa et al. (2009) claimed that high pressure processing (600 MPa) increased the hardness of restructured dry-cured ham. Moreover, corrective mild thermal treatments have also been addressed. Thus, Gou et al. (2008) affirmed that a 10-day ageing at $30{ }^{\circ} \mathrm{C}$ could be a useful means of reducing the problems associated with soft dry-cured hams with no effect on the product flavor. Morales et al. (2008) assessed textural changes in dry-cured ham pieces by means of mild thermal treatments during different times and temperatures, but only the thermal treatment at $30^{\circ} \mathrm{C}$ for 7 days decreased the softness in Biceps femoris muscle. Some of the main drawbacks of these previous studies are the high cost of high- pressure treatments and the long time period required to improve the dry-cured ham texture when using mild thermal treatments. Therefore, the search for intensification methods in order to shorten the processing times of mild thermal treatments could be an interesting cost-effective option.

In recent years, power ultrasound $(\mathrm{PuS})$ has emerged as an interesting method for process intensification in several engineering applications. Ultrasonic waves have been used to overcome heat and mass transfer limitations. Many studies have proven the enhancement of heat transfer under the influence of ultrasonic vibrations, most of which focused on heat transfer convection (Legay et al., 2011). Additionally, the ultrasound-assisted intensification of heat exchangers has been addressed, revealing that the overall heat transfer coefficient is always higher under ultrasonic conditions (Gondrexon et al., 2015; Legay et al., 2012). This improvement in heat transfer is mainly due to acoustic cavitation, acoustic streaming and fluid particle oscillations. Basically, the cavitation and microagitation produced by ultrasound in the liquid medium are responsible of reducing heat transfer resistance by increasing fluid turbulence.

As regards the application of ultrasound in the food sector, it has been formerly used in sterilization (Piyasena et al., 2003), extraction (Ahmad-Qasem et al., 2013; Jadhav et al., 2009; Tiwari, 2015), filtration (Masselin et al., 2001), drying (Fan et al., 2017; Musielak et al., 2016; 
Santacatalina et al., 2016b) or freezing (Zheng \& Sun, 2006) to increase the efficiency or shorten the processing times. In these applications, ultrasound was used to intensify mass transfer, heat transfer or both phenomena simultaneously. Thus, as examples of mass transfer intensification, Ozuna et al. (2014) shortened the drying time for salted cod by up to $50 \%$ (20 ${ }^{\circ} \mathrm{C}, 20.5 \mathrm{~kW} / \mathrm{m}^{3}$ ), while Santacatalina et al. (2016a) sped up the drying process of apple by up to $80 \%\left(-10^{\circ} \mathrm{C}, 32 \mathrm{~kW} / \mathrm{m}^{3}\right)$. As far as the coupling of ultrasonic waves in heat transfer processes is concerned, it has been used in both cooling and heating processes. As to cooling, Li \& Sun (2002) reported that acoustic energy could lead to a noticeable increase in the freezing rate of potato and Delgado et al. (2009) also showed that the application of ultrasound could increase the freezing efficiency of apples. Regarding heating, although several applications of PuSassisted heating in gas and liquid medium have been studied (Chemat et al., 2011; Rodríguez et al., 2018), research into the ultrasonically-assisted heating of solid foods is scarce in the literature, particularly the heating of ready-to-eat products. Therefore, there exists a need to investigate the behavior of the product during heating and test whether the additional acoustic energy during the heat treatment leads to a shortening of the heating time. In this context, the objective of this study was to explore the feasibility of using PuS to intensify heat transfer during the mild thermal treatment of dry-cured ham in a liquid medium.

\section{Materials and methods}

\subsection{Raw material}

Dry-cured ham slices (20.4 $\pm 1.2 \mathrm{~cm}$ length, $2.0 \pm 0.1 \mathrm{~cm}$ thick) were purchased at a local supplier from deboned commercial pieces and immediately vacuum packaged in plastic film and stored at $4{ }^{\circ} \mathrm{C}$ until treated. Additionally, cylinders were taken from different slices of ham, $4 \pm 0.2 \mathrm{~cm}$ thick and also purchased from a local supplier, using a household tool, further split into two identical cylindrical pieces ( $2 \mathrm{~cm}$ in diameter and $2.0 \pm 0.2 \mathrm{~cm}$ in height), one of them was treated and the other one was kept as control in order to assess the impact of the heating in the textural properties. Afterwards, the samples were vacuum-packed in plastic film of polyamide/polyethylene (oxygen permeability of $50 \mathrm{~cm} 3 / \mathrm{m} 2 / 24 \mathrm{~h}$ at $23{ }^{\circ} \mathrm{C}$ and water permeability of $2.6 \mathrm{~g} / \mathrm{m} 2 / 24 \mathrm{~h}$ at $23{ }^{\circ} \mathrm{C}$ and $85 \% \mathrm{RH}$, Sacoliva ${ }^{\circledR}$ S.L., Spain) and stored at $4{ }^{\circ} \mathrm{C}$. The extracted cylinders were randomly distributed in the slice without muscle distinction.

Fat, salt and moisture contents were determined in ham slices and cylinders. Fat and moisture contents were analyzed following AOAC procedures 991.36 and 950.46, respectively (AOAC, 1997), and salt content was analyzed using a Chloride Analyzer equipment (Chloride Meter 926L, Ciba Corning, U.K.) following the process described by de Prados et al. (2015). All the analyses were performed in triplicate. A wide range of dry-cured ham samples of 
differing composition was selected. Thus, the fat content ranged from 2.4 to $16.2 \%$ (wet basis) and the salt content varied from 2.8 to $8.6 \%$ (wet basis). The average moisture content in both slices and cylinders was $52 \pm 6 \%$ (wet basis).

\subsection{Heat treatments: Conventional (CV) and Ultrasonically-assisted (PuS)}

Heat treatments were carried out in a stainless steel 15 L ultrasonic bath (ATG15160, ATU, Spain) using water as the heating medium. The bath was provided with a temperature control system (Figure 1). Temperature control was based on recycling the water bath using the available upper and lower connections. The upper connection was used to keep the water level in the tank constant. Thus, the output water stream was driven to a reservoir tank $(5 \mathrm{~L})$ provided with a circulating thermostat (Digiterm TFT-200, Selecta, Spain), which kept the liquid in agitation as well as impelling it $(3.5 \mathrm{~L} / \mathrm{min})$ through a plate heat exchanger (EL852, Mas Malta Cervecera, Spain). As the cooling liquid, a solution of glycol $(40 \% \mathrm{v} / \mathrm{v})$ provided by a refrigerated circulating bath (1190s, Refrigerator Circ, US) was used in the heat exchanger. The output water stream of the heat exchanger was introduced into the water bath using its lower connection, closing the water circuit loop. An ON-OFF control was implemented by acting through the working time of the circulating thermostat of the water reservoir tank. For that purpose, a Pt-100 sensor was connected to a process controller (E5CK, Omron, Japan) which acted on the circulating unit.

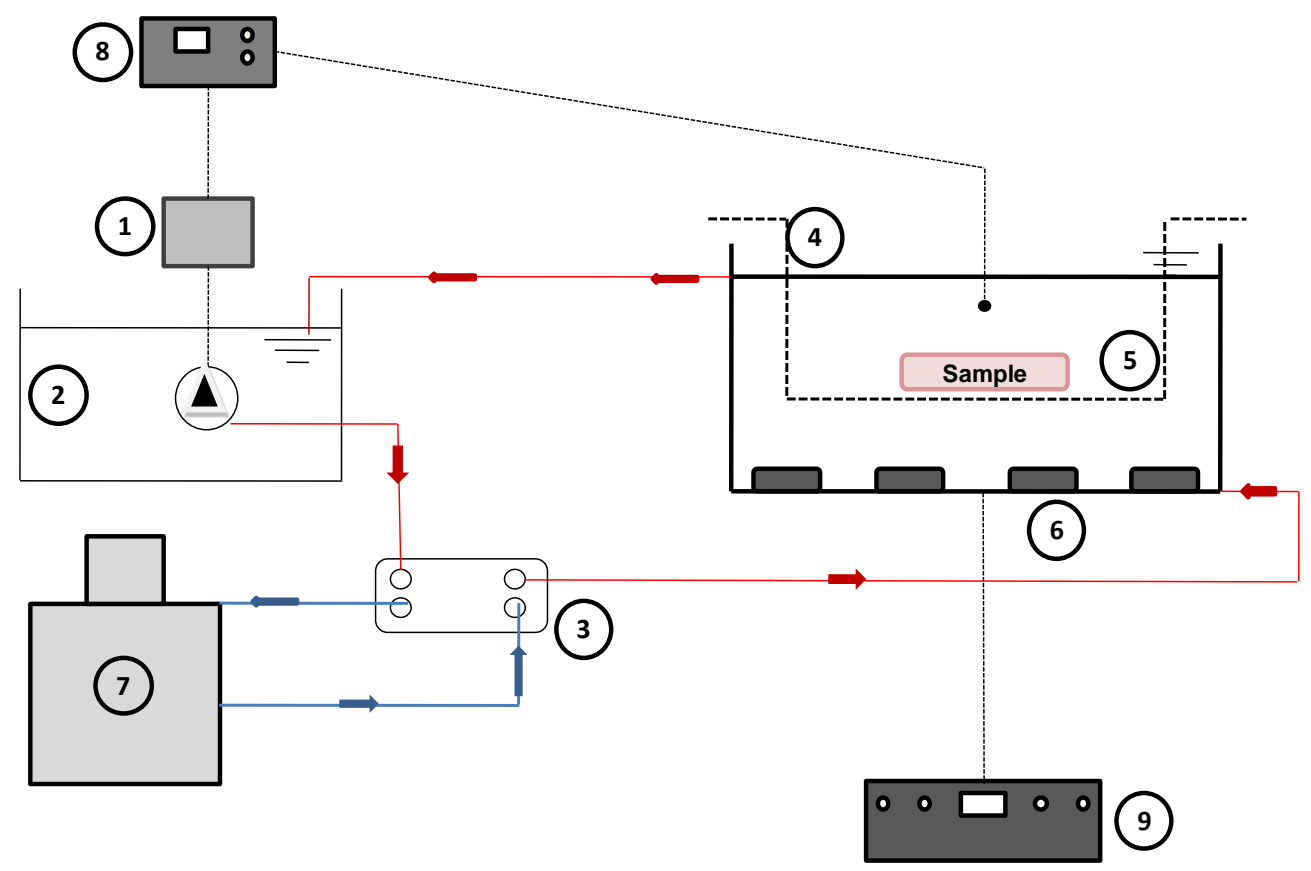

Figure 1. Scheme of the temperature controlled ultrasonic bath. 1, Circulating thermostat; 2, Water reservoir tank; 3, Plate heat exchanger; 4, Ultrasonic bath; 5, Basket sample holder; 6, Ultrasonic transducers; 7, Refrigerated circulating bath; 8, Process controller; 9, Ultrasonic generator and amplifier. 
Ultrasonically-assisted $(\mathrm{PuS})$ and conventional $(\mathrm{CV})$ heat treatments were performed using the experimental set-up shown in Figure 1. In PuS experiments, the ultrasonic generator (GAT600W ATU, Spain) supplied an electric power of $600 \mathrm{~W}$ and $20 \mathrm{kHz}$ to the transducers and the heating system of the circulating thermostat was only activated at the beginning until water temperature reached the set point. Afterwards, the heater was switched off and due to the heat generation linked to ultrasonic cavitation, the chiller was switched on (set point $-2{ }^{\circ} \mathrm{C}$ ). Thus, passing the water through the heat exchanger allowed reducing the additional heat generated by cavitation. In CV experiments, a mechanical stirrer (D91126, Heidolph Instruments, Germany) provided with a pitched blade impeller (diameter $75 \mathrm{~mm}$ ) was placed into the ultrasonic bath $(360 \mathrm{rpm})$ in order to increase the turbulence and ensure temperature homogeneity. In addition, the heating system was set to the target temperature of the experiment and the chiller was switched-off since there did not exist heat generation. As already mentioned, in both PuS and CV experiments, the actuator in the control loop was the circulating thermostat of the water reservoir tank. This experimental set up allowed an accurate control of the temperature in the water bath for both PuS and CV experiments.

Samples were placed at $4 \mathrm{~cm}$ from the bottom of the ultrasonic bath, using a basket as a holder (Figure 1). For ham slices, the temperature was measured in both Semimembranosus (SM) and Biceps femoris (BF) muscles, following the scheme shown in Figure 2. Thus, in each muscle, two type-T thermocouples were placed at 1 (center of the slice; $\mathrm{X}=0$, Figure 2 ) and 0.5 $\mathrm{cm}$ from the surface $(X=0.5$, Figure 2$)$, these points coinciding with the total $(\mathrm{L})$ and half $(\mathrm{L} / 2)$ characteristic dimension of the slice, respectively. Type-T thermocouples ( $0.5 \mathrm{~mm}$ in diameter) were inserted into a hypodermic needle in order to make its location easier. In order to minimize the water and air entrance into the package, a silicon strip $(3 \times 3 \times 2 \mathrm{~mm}, \mathrm{CHA}-475, \mathrm{CYH}$ Sistemas, Spain) was placed over the puncture point before the hypodermic needle was pricked. In addition, two type-K thermocouples were stuck onto the surface of the slice with adhesive tape. In the case of ham cylinders, on the other hand, only a Type-T thermocouple was placed at the geometrical center. Thermocouples were connected to a PC through a data logger (34970A, Agilent, U.S.A) using the RS-232 interface. 


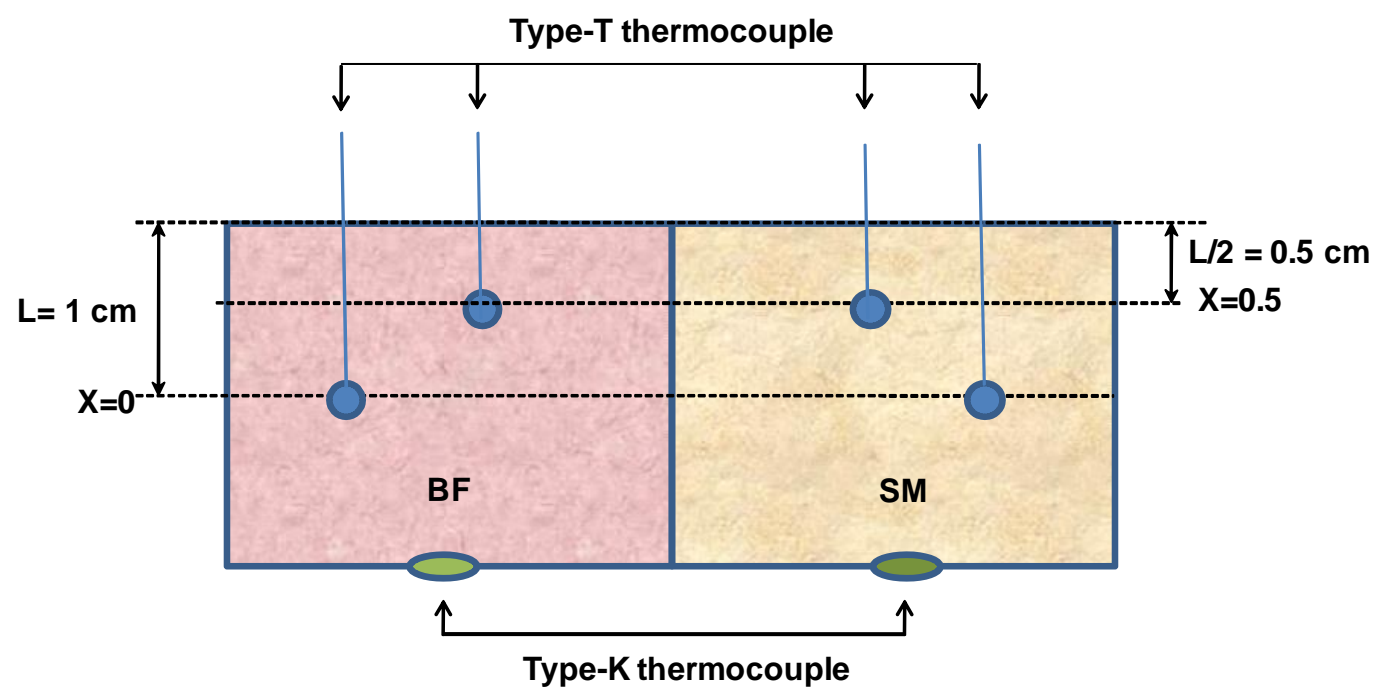

Figure 2. Scheme of thermocouple location on ham slices (thickness $2 \mathrm{~cm}$ ) during thermal treatment.

$\mathrm{PuS}$ and $\mathrm{CV}$ heating treatments of ham slices were carried out at different bath temperatures $\left(40,45\right.$ and $\left.50^{\circ} \mathrm{C}\right)$. Every heating condition was tested in triplicate at least. Thus, the total number of experiments carried out was 18 (2 ultrasound application $\mathrm{x} 3$ temperatures $\mathrm{x}$ 3 replicates). The range of temperatures was chosen based on previous experiments to avoid dry-cured ham cooked flavor but inducing textural changes. In every case, experiments were extended until a temperature $5{ }^{\circ} \mathrm{C}$ lower than the pre-set temperature of the water bath was reached in the center of the slice or cylinder. The temperature was monitored and logged every $20 \mathrm{~s}$ during the heating treatments. Each heating condition was tested at least three times.

\subsection{Modelling}

Modelling was used to compute the influence of the process variables (ultrasound application, temperature and type of muscle) on the overall heating process of ham slices. For that purpose, a diffusive model that considered heat transfer to be entirely controlled by conduction was chosen, assuming that the sample surface temperature reached equilibrium with the water temperature instantaneously and therefore, considering negligible the external resistance to heat transfer. No additional external resistance was assigned to the plastic film. Ham was supposed to be homogeneous and isotropic, with negligible contraction and constant apparent thermal diffusivity. In addition, due to the average slice shape (length $20 \pm 1$, thickness $2 \pm 0.1$ and width $10 \pm 1 \mathrm{~cm}$ ), the samples were assumed to behave as infinite slab bodies in terms 
of heat transfer. Thus, the conduction equation (Eq. 1) (Holman, 1986) used is written as follows:

$$
T_{(x, t)}=T_{\infty}+\left(T_{0}-T_{\infty}\right)\left(2 \sum_{n=0}^{\infty} \frac{(-1)^{n}}{\beta_{n} L} e^{-\alpha \beta_{n}^{2} t} \cos \left(\beta_{n} x\right)\right)
$$

where $T_{0}$ is the initial temperature (refrigeration temperature, $5 \pm 2{ }^{\circ} \mathrm{C}$ ) of dry-cured ham, $T_{\infty}$ is the water bath temperature $\left(40,45\right.$ or $50{ }^{\circ} \mathrm{C}$, depending on the experiment tested), $\beta_{n}$ are the eigenvalues calculated as $\beta_{n}=(2 n+1) \frac{\pi}{2 L}, L$ is the half-thickness of the slice $(\mathrm{m}), \alpha$ is the apparent thermal diffusivity $\left(\mathrm{m}^{2} / \mathrm{s}\right), t$ is the time (s) and $x$ is the axial direction (m).

The apparent thermal diffusivity $(\alpha)$ was identified by fitting Eq. 1 to the temperature evolution during heating in two different positions of the slice, $x=0$ and $x=L / 2$ (Figure 2), and for both SM and BF muscles. The identification was carried out by minimizing the sum of the squared differences between the experimental and calculated temperatures. For that purpose, the solver optimization tool available in Microsoft Excel 2016 was used. The goodness of the fit was assessed by calculating the percentages of explained variance (VAR, Eq. 2) and the mean relative error (MRE, Eq. 3),

$$
\begin{aligned}
& \operatorname{VAR}(\%)=\left[1-\frac{\mathrm{S}_{\mathrm{xy}}^{2}}{\mathrm{~S}_{\mathrm{y}}^{2}}\right] \cdot 100 \\
& \operatorname{MRE}(\%)=\frac{\sum_{i=1}^{N}\left|\frac{T_{e i}-T_{c i}}{T_{e i}}\right|}{N}
\end{aligned}
$$

where $S_{x y}$ and $S_{y}$ are the standard deviations of the estimation and the sample, respectively, $T_{e i}$ and $T_{c i}$ are the experimental and calculated temperatures and $N$ is the number of experimental data. An MRE below 10\% could be considered an adequate fit, such as reported by Garau et al. (2006) and Park et al. (2002).

Additionally, dry-cured ham cylinders were used for model validation. In this way, ham cylinders were heated at $50{ }^{\circ} \mathrm{C}$, assisted with PuS. The cylinders were selected for validation for the purpose of checking the robustness of the model regardless of the shape of the dry-cured ham used. Moreover, the apparent thermal diffusivity identified using PuS treatments of ham slices at $50{ }^{\circ} \mathrm{C}$ were used to simulate the temperature evolution in the center of finite cylinders (diameter $2 \mathrm{~cm}$, height $1.7 \pm 0.3 \mathrm{~cm}$ ). The corresponding diffusive model is shown in Eq. 4 (Holman, 1986): 


$$
T_{(x, r, t)}=T_{\infty}+\left(T_{0}-T_{\infty}\right)\left(2 \sum_{n=0}^{\infty} \frac{(-1)^{n}}{\beta_{n} L} e^{-\alpha \beta_{n}^{2} t} \cos \left(\beta_{n} x\right)\right)\left(2 \sum_{n=1}^{\infty} \frac{e^{-\alpha \lambda_{n}^{2} t}}{\lambda_{n} R J_{1}\left(\lambda_{n} R\right)} J_{0}\left(\lambda_{n} r\right)\right)(4)
$$

where $\lambda_{n}$ are the eigenvalues calculated as $\lambda_{n} / J_{0}\left(\lambda_{n} R\right)=0, R$ is the cylinder radius (m), $J_{l}$ and $J_{0}$ are the Bessel functions of the first kind of order 1 and 0 , respectively and $r$ is the radial direction $(m)$.

In order to validate the diffusive model, experimental and simulated temperatures were compared and VAR and MRE (Eqs. 2 and 3, respectively) were computed.

\subsection{Statistical analysis}

A two-way analysis of variance (ANOVA) was performed in order to assess the influence of processing factors (temperature: 40,45 and $50{ }^{\circ} \mathrm{C}$ and heating treatment: $\mathrm{CV}$ and $\mathrm{PuS}$ ) on the identified apparent thermal diffusivity. In addition, a one-way ANOVA was used to study the effect of both the type of muscle (BF and SM) on the apparent thermal diffusivity, as well as that of the positions, $x=0$ and $x=L / 2$, on the kinetic parameter. In every case, a significance level of $95 \%$ was considered. The statistical analysis was performed using Statgraphics Centurion XVI (Statpoint Technologies Inc., Warrenton, VA, USA).

\subsection{Textural properties}

The textural properties of dry-cured ham cylinders were measured using a TA-XT2 texturometer (SMS, Godalming, UK) provided with a load cell of $50 \mathrm{~kg}$. A flat $75 \mathrm{~mm}$ diameter aluminum plunger (SMS P/75) was used to carry out the stress-relaxation test. The samples were compressed to $25 \%$ of their original height parallel to the fiber bundle direction at a crosshead speed of $1 \mathrm{~mm} / \mathrm{s}$ and afterwards, the probe was held for $90 \mathrm{~s}$ to monitor relaxation. The measurements were done at constant temperature $\left(4 \pm 1{ }^{\circ} \mathrm{C}\right)$. The experimental data were recorded and processed with Exponent Lite 6.1.4.0 software (SMS, Godalming, UK). Thus, hardness was computed from the force versus time profiles as the maximum force achieved during compression and the level of force decay $(Y)$ logged during relaxation was calculated as follows:

$$
Y=\frac{F_{0}-F_{90}}{F_{0}}
$$


where $F_{0}$ is the maximum force during compression $(\mathrm{N})$ and $F_{90}$ is the force recorded at the end of the stress-relaxation test (90 s). The difference between treated and control samples was calculated for every texture parameter in order to quantify the changes in the texture of drycured hams after the heat treatment.

\section{Results and discussion}

\subsection{Heating kinetics}

The heating kinetics of $\mathrm{CV}$ and $\mathrm{PuS}$ experiments on BF muscle are shown in Figure 3. For every temperature studied, the heat treatment was considered to have ended when the target temperature $\left(5{ }^{\circ} \mathrm{C}\right.$ below the water bath temperature) was reached in the center of the sample. The CV heating kinetics presented in Figure 3A revealed the typical shape of a heat transfer process controlled by conduction: there exists a short latency period, less noticeable at $50{ }^{\circ} \mathrm{C}$, followed by an exponential increase in the temperature and, finally, the kinetic tends towards an asymptotic value. As expected, the bath temperature during the heating of dry-cured ham influenced the heating kinetics in CV experiments. The higher the water temperature, the higher the product temperature for a particular treatment time. Thus, higher temperatures shortened the time needed to reach a specific temperature. As an example, to reach $25{ }^{\circ} \mathrm{C}$ in the center of the product, $6.7 \pm 0.4,5.7 \pm 0.2$ and $4.4 \pm 0.1$ minutes were needed when the bath temperature was 40 , 45 and $50{ }^{\circ} \mathrm{C}$, respectively (Figure 3A). This occurs because the increase in the temperature gradient between the product and the medium leads to an increase in the driving force for heat transfer, resulting in a larger heat flow. However, the application of PuS during dry-cured ham heating partially modified the effect of the water temperature on heating kinetics. As can be observed in PuS experiments (Figure 3B), the time needed to reach $25^{\circ} \mathrm{C}$ was similar at every temperature tested, $3.5 \pm 0.4 \mathrm{~min}$, a shorter time than either of the $\mathrm{CV}$ experiments, indicating that the heat transfer process was affected by PuS. The same tendency was observed in SM muscle. 

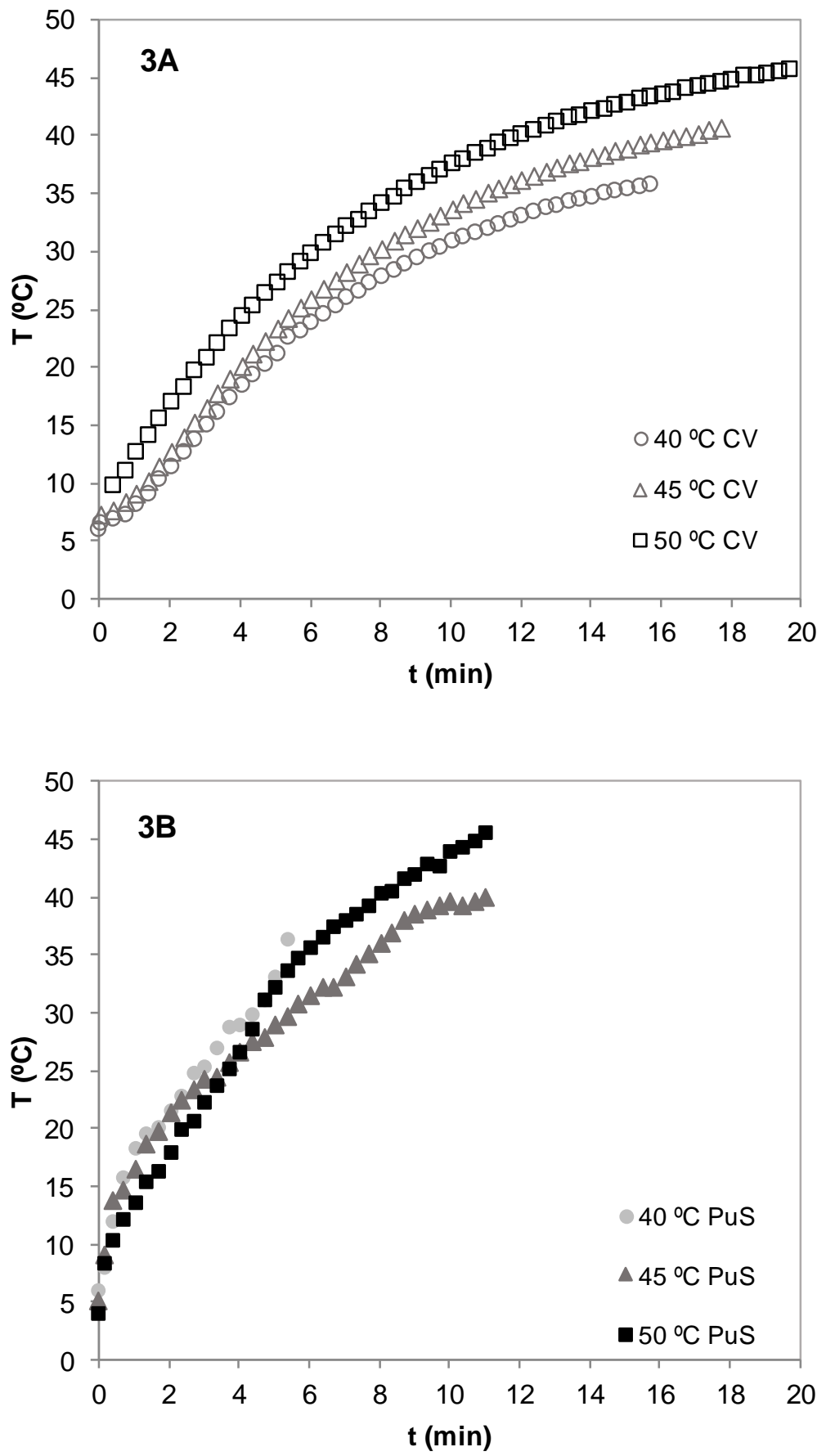

Figure 3. Heating kinetics of dry-cured ham slices $(x=0)$ in $B F$ muscle at different temperatures (3A: Conventional heating (CV); 3B: Ultrasonically-assisted heating (PuS).

To assess the influence of $\mathrm{PuS}$ on heating kinetics for the different heating temperatures, $\mathrm{CV}$ and $\mathrm{PuS}$ heating kinetics were compared at every temperature tested (Figure 4 shows heating kinetics for SM muscle). CV heat treatments presented a gradual, smooth temperature increase, while instabilities, sharp fluctuations in temperature, were observed in $\mathrm{PuS}$ heating kinetics; this was probably due to cyclic compressions and expansions produced by 
ultrasound at microscopic level in the material (Cárcel et al., 2012). For every temperature studied, the heating kinetics were faster when PuS was applied (Figure 4), demonstrating that $\mathrm{PuS}$ application exerted a great influence on the shortening of the heating time. However, how much shorter varied depending on the temperature used. Thus, for SM muscle, the time differences between CV and PuS treatments at the end of the experiments carried out at 40, 45 and $50{ }^{\circ} \mathrm{C}$ were $6.4 \pm 0.5,4.7 \pm 1.1$ and $4 \pm 0.6 \mathrm{~min}$, respectively. These results confirmed that the higher the temperature, the milder the influence of PuS on the heating time. Thereby, a time saving of $35 \%$ was obtained when comparing $\mathrm{PuS}$ and $\mathrm{CV}$ experiments performed at $40{ }^{\circ} \mathrm{C}$, while the percentage was only $21 \%$ at $50{ }^{\circ} \mathrm{C}$. The same behavior was noticed for BF muscle. This could be ascribed to the fact that, at high temperatures, the mechanical energy supplied to the medium by $\mathrm{PuS}$ is practically negligible compared with the thermal energy introduced into the medium by hot water. This observation is coherent with results found by García-Pérez et al. (2006) studying hot air drying, where the effect of ultrasound on mass transfer during drying lessened as the temperature increased.

The application of ultrasound in meat processing and the consequent time-saving has been the subject of prior research. Pohlman et al. (1997) found remarkable advantages as regards how fast beef was cooked in the presence of ultrasound, reducing the cooking time by half. Additionally, Miles et al. (1999) reported that acoustic application shortened the defrosting time: the thawing times of Semitendinosus beef muscle were considerably shorter using ultrasound (from 32 to $66 \%$ shorter, depending on the PuS frequency and intensity used) compared to conventional thawing at a constant temperature of $25^{\circ} \mathrm{C}$.

The effect of PuS on heat transfer, as well as the predominant heat transfer phenomena taking place, will be analyzed in the subsequent modelling section. 

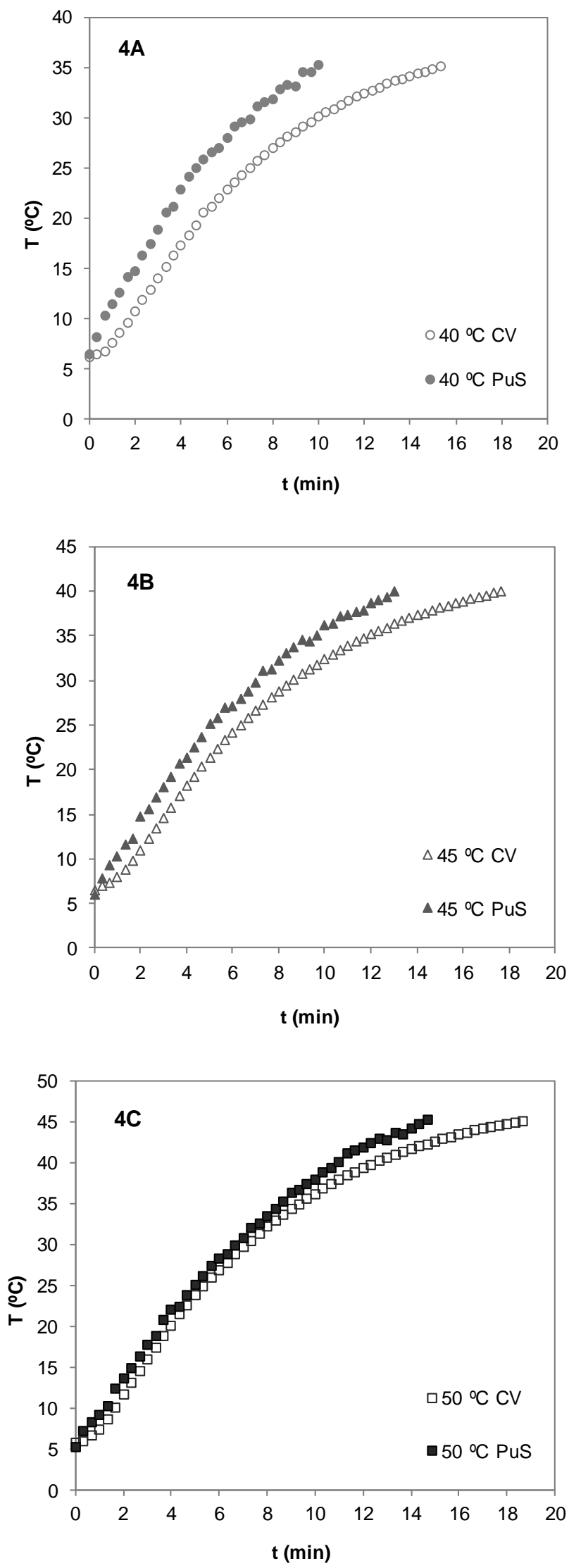

Figure 4. Heating kinetics of dry-cured ham slices $(x=0)$ in SM muscle at different temperatures (CV: Conventional heating; PuS: Ultrasonically-assisted heating). 


\subsection{Modelling of the heating kinetics}

Table 1 shows the apparent thermal diffusivity $(\alpha)$ and apparent thermal diffusivity variation $(\Delta \alpha)$ between $\mathrm{PuS}$ and $\mathrm{CV}$ experiments carried out at 40,45 and $50^{\circ} \mathrm{C}$ on $\mathrm{SM}$ and $\mathrm{BF}$ muscles. As expected, after fitting the conduction model (Eq. 1) to the experimental heating kinetics, it was observed that the position $(x=0 ; x=0.5$; Figure 2$)$ of the thermocouple in the sample did not have a significant ( $p>0.05)$ influence on the apparent thermal diffusivity. For that reason, the average apparent thermal diffusivity of both sensor positions for every heating condition is reported in Table 1. The conduction model used was an accurate means of describing the heating kinetics of dry-cured ham under the different conditions tested, providing percentages of explained variance higher than $98.6 \%$ and mean relative errors lower than $6 \%$ (Table 1). The close fit between experimental and calculated data indicated that the hypothesis considered, whereby the product surface instantaneously reaches water bath temperature, was adequate (heat transfer entirely controlled by conduction). Thus, mechanical agitation in CV experiments, as well as cavitation and liquid microturbulence in PuS experiments, minimized the effect of external resistance to heat transfer, which became negligible compared to the internal kind. The accuracy of the model proposed for describing the heating kinetics of SM muscle $(\mathrm{x}=0)$ is plotted in Figure 5, where experimental data and calculated curves are compared at every temperature tested. Most of the studies dealing with ultrasound-assisted heating found in the literature only focus on heat convection and consider as negligible the influence of power ultrasound on thermal diffusivity, which is considered as a constant parameter dependent on the product properties. The importance of internal mass transport resistance has been evidenced in convective drying of solid foods assisted by PuS, where a coupled heat and mass transfer exists (Musielak et al., 2016). In this study, the modelling of heating kinetics (Table 1 and Figure 5) demonstrated that the heating of dry-cured pork ham under these experimental conditions was entirely controlled by conduction. This is also supported by the temperature measurement taken on the product surface (Figure 2), which evidenced that product temperature rapidly reaches $(0.8 \pm 0.4 \mathrm{~min})$ the water temperature in both $\mathrm{CV}$ and PuS experiments. 

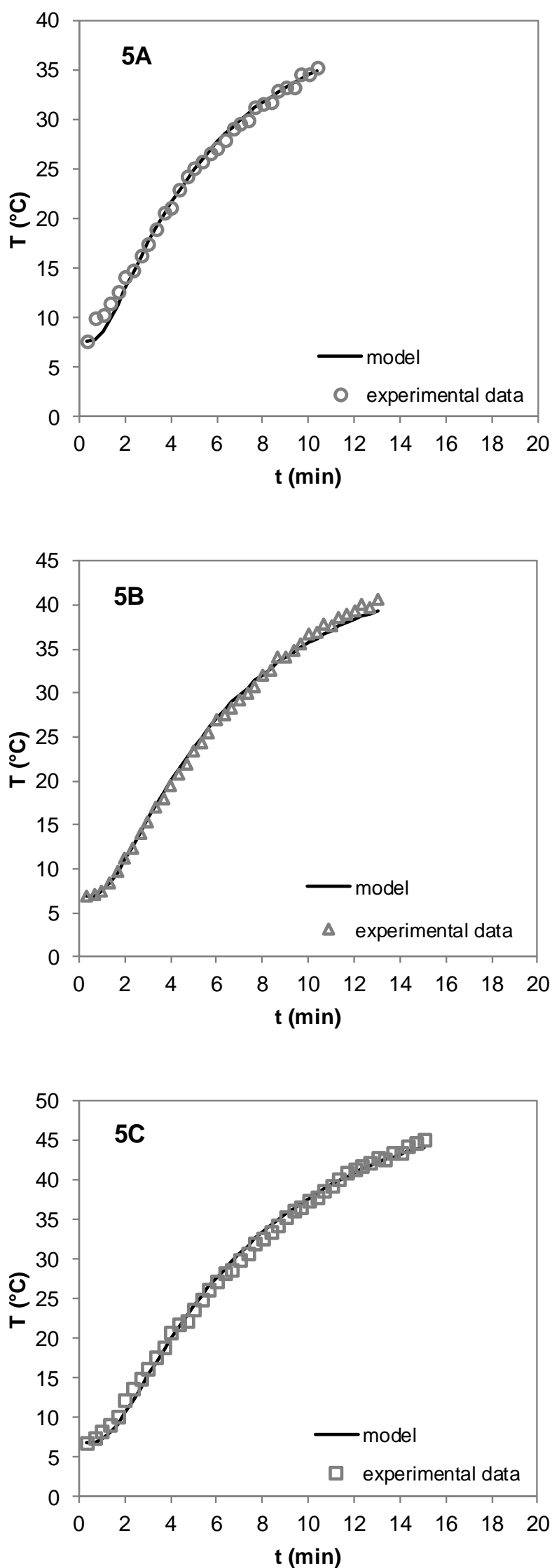

Figure 5. Experimental and modeled PuS heating kinetics of dry-cured ham slices in SM muscle $(\mathrm{x}=0)$ at different temperatures $\left(5 \mathrm{~A}: 40^{\circ} \mathrm{C} ; 5 \mathrm{~B}: 45^{\circ} \mathrm{C} ; 5 \mathrm{C}: 50{ }^{\circ} \mathrm{C}\right)$. 
From the CV experiments, statistically similar values of $\alpha$ were found at every heating condition tested (Table 1), regardless of the temperature and the type of muscle considered. However, in the PuS experiments, the bath temperature significantly affected $(\mathrm{p}<0.05)$ the apparent thermal diffusivity. Consequently, in the BF muscle, the lower the temperature tested, the higher the $\alpha$, reaching the greatest value at $40^{\circ} \mathrm{C}\left(1.86 \pm 0.3 \times 10^{-7} \mathrm{~m}^{2} / \mathrm{s}\right)$. A similar tendency was observed for the SM muscle. As for the influence of muscle factor on the apparent thermal diffusivity of the PuS experiments, the comparison between BF and SM heated at the same temperature showed that $\alpha$ was smaller for the SM muscle in every case, but such differences were not statistically significant ( $p>0.05)$.

Table 1. Apparent thermal diffusivity $(\alpha)$ and its variation $(\Delta \alpha)$ between $\mathrm{CV}$ and PuS experiments carried out at 40,45 and $50{ }^{\circ} \mathrm{C}$ in $\mathrm{SM}$ and $\mathrm{BF}$ muscles.

\begin{tabular}{c|c|ccc|ccc|c}
\hline $\begin{array}{c}\mathbf{T} \\
\left({ }^{\mathbf{0}}\right)\end{array}$ & Muscle & \multicolumn{3}{|c|}{ PuS } & \multicolumn{3}{c|}{ CV } & V \\
\hline $\mathbf{4 0}$ & $\mathbf{S M}$ & $1.35 \pm 0.2^{\mathrm{C}}$ & 99.16 & 3.98 & $0.98 \pm 0.08^{\mathrm{A}}$ & 99.38 & 4.08 & 38 \\
$\mathbf{4 5}$ & $\mathbf{S M}$ & $1.41 \pm 0.3^{\mathrm{C}}$ & 99.39 & 2.09 & $1.23 \pm 0.3^{\mathrm{ABC}}$ & 99.19 & 2.28 & 15 \\
$\mathbf{5 0}$ & $\mathbf{S M}$ & $1.10 \pm 0.1^{\mathrm{AB}}$ & 99.22 & 4.67 & $1.10 \pm 0.1^{\mathrm{A}}$ & 99.58 & 5.21 & 9 \\
\hline $\mathbf{4 0}$ & $\mathbf{B F}$ & $1.86 \pm 0.3^{\mathrm{c}}$ & 98.83 & 5.74 & $1.23 \pm 0.4^{\mathrm{a}}$ & 99.75 & 5.12 & 51 \\
$\mathbf{4 5}$ & $\mathbf{B F}$ & $1.56 \pm 0.2^{\mathrm{bc}}$ & 98.64 & 4.86 & $1.2 \pm 0.3^{\mathrm{ab}}$ & 98.98 & 4.97 & 30 \\
$\mathbf{5 0}$ & $\mathbf{B F}$ & $1.34 \pm 0.2^{\mathrm{ab}}$ & 99.03 & 5.81 & $1.11 \pm 0.1^{\mathrm{a}}$ & 99.52 & 5.90 & 21 \\
\hline
\end{tabular}

$\Delta \alpha$ was calculated as $\left(\alpha_{\mathrm{PuS}}-\alpha_{\mathrm{CV}}\right) / \alpha_{\mathrm{CV}}$. VAR $(\%)$ is the explained variance and MRE (\%) the percentage of mean relative error. Superscripts in capital letters (A, B, C) and lowercase letters (a, b, c) show homogeneous groups established from LSD (Least Significance Difference) intervals $(\mathrm{p}<0.05)$ obtained by multifactor ANOVA (temperature and treatment time as factors) for $\alpha$ of SM and BF muscle heating experiments, respectively.

Additionally, the apparent thermal diffusivity was used to analyze the effect of PuS application on heat transfer. Thus, the average apparent thermal diffusivity in CV experiments was $1.1 \pm 0.1 \times 10^{-7} \mathrm{~m}^{2} / \mathrm{s}$, which was significantly $(\mathrm{p}<0.05)$ lower than in PuS experiments $\left(1.4 \pm 0.2 \times 10^{-7} \mathrm{~m}^{2} / \mathrm{s}\right)$. Singh (1982) found a $\alpha$ of $1.38 \times 10^{-7} \mathrm{~m}^{2} / \mathrm{s}$ in smoke ham for temperatures ranging from 40 to $65^{\circ} \mathrm{C}$, a value lying between those found in $\mathrm{CV}$ and $\mathrm{PuS}$ experiments in the present study. For either of the temperatures tested, ultrasound application during heating involved a significant $(\mathrm{p}<0.05)$ increase in the kinetic parameter. The apparent thermal diffusivity variation, $\Delta \alpha=\left(\alpha_{\mathrm{Pus}}-\alpha_{\mathrm{CV}}\right) / \alpha_{\mathrm{CV}}$, increased by between 9 and $51 \%$ in the presence of acoustic waves (Table 1). The reported results revealed that power ultrasound application implied a significant improvement in conduction heat transfer, which has not been previously reported. Ultrasonic intensification could be explained by considering that the alternating expansions and contractions produced by ultrasonic vibration facilitate molecular heat transport, resulting in higher thermal conductivity. In addition, the vibration of solid particles at microscopic level could also bring about an increase in temperature by particle friction; 
although this could be considered as internal heat generation, which is included in the model as an unknown factor affecting the apparent thermal diffusivity. The improvement in $\alpha$ produced by $\operatorname{PuS}(\Delta \alpha)$ in both muscles was reduced as the bath temperature rose, indicating that, as previously mentioned, ultrasound was more effective at low temperatures (Table 1). In ultrasound assisted drying and blanching processes, the influence of temperature on ultrasonic intensification was similar to the present study, the influence of PuS being more marked at the lowest temperatures. In this sense, Lespinard et al. (2015) reported an improvement of $205 \%$ in the convective heat transfer coefficient (h) when PuS was applied at a blanching temperature of $90{ }^{\circ} \mathrm{C}$, while at $60{ }^{\circ} \mathrm{C}$ it rose up to $599 \%$. As previously explained, this could be linked to the proportion of acoustic and thermal energy compared to the total energy introduced into the medium. In such a way, higher temperatures supplied a greater thermal energy to the water bath, affording less relevance to PuS energy.

\subsection{Model validation}

As indicated in section 2.3, the heat transfer model was validated by the PuS-assisted heating of 18 cylinders of dry-cured ham at $50{ }^{\circ} \mathrm{C}$. The cylinders were randomly taken without considering the relevance of the muscle in order to check the robustness of the model to further describe the heating of whole slices. For that purpose, the average apparent thermal diffusivity previously identified in slices of both $\mathrm{SM}$ and $\mathrm{BF}$ muscles heated at $50{ }^{\circ} \mathrm{C}$ within $\mathrm{PuS}$ experiments was used and the heating of the cylinders was simulated through Eq. 4. As an example, Figure 6 shows the experimental and simulated heating kinetics of one dry-cured ham cylinder. The average explained variance and mean relative error of every validation experiment were $99 \%$ and $4 \%$, respectively, indicating a good fit of the model to the experimental data. This indicated that the proposed model and the obtained apparent thermal diffusivity values were robust and could be used to predict the heating behavior of dry-cured ham slices. 


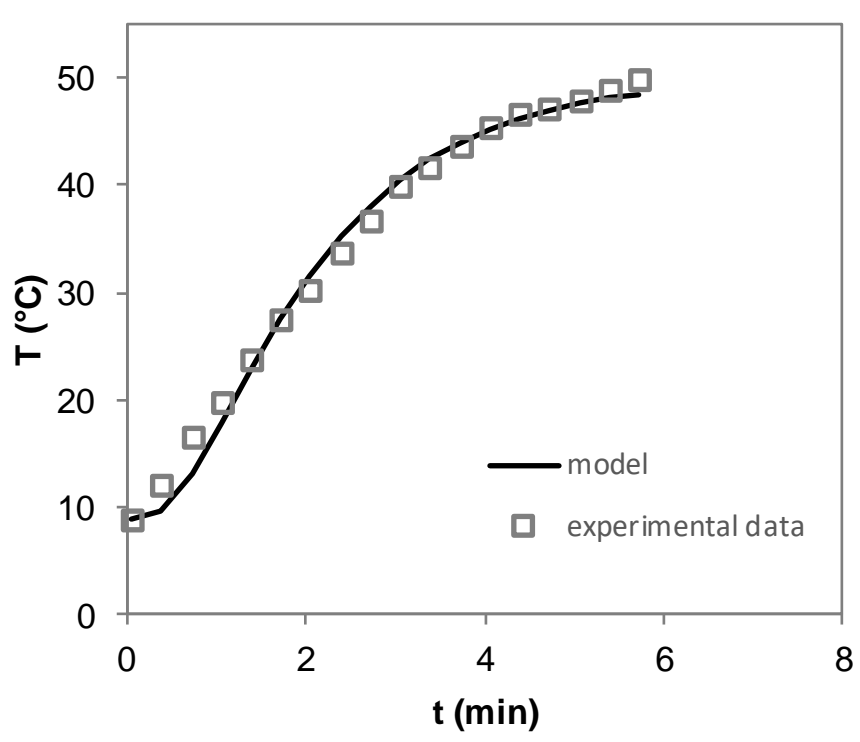

Figure 6. Experimental and simulated heating kinetics of a dry-cured ham cylinder heated at $50{ }^{\circ} \mathrm{C}$ and PuS-assisted.

\subsection{Textural properties}

In order to quantify the influence of the treatment on dry-cured ham texture, stressrelaxation tests were carried out in the cylinders heated at $50{ }^{\circ} \mathrm{C}$. Thus, the increment of textural parameters was calculated as the difference between the treated samples and their controls. In every experiment, the hardness variation was positive, indicating that dry-cured ham became harder after the heat treatment. The average enhancement of hardness was $15.2 \pm 4.4 \mathrm{~N}$, which is in concordance with the hardness variation reported by Contreras et al. (2018) when heating ham with hot air at the same temperature (treatment times ranged from 18 to 24 minutes). Force decay was also measured in order to evaluate the elasticity of the treated ham. Thus, the average variation of the force decay for treated samples regarding the control ones was of $-0.078 \pm 0.057$, which indicated an improvement in ham elasticity since the smaller the force decay, the larger the elasticity (Garcia-Gil et al., 2014).

\section{Conclusions}

This study illustrates the feasibility of applying power ultrasound to accelerate the heating kinetics of dry-cured ham. The improvement in the heat transport produced by ultrasound was noticeable from the shortening of the heating time. The ultrasonic effect on heating experiments was greater at low temperatures, increasing the apparent thermal diffusivity by up to $51 \%$. Modelling revealed that ultrasonic intensification mainly focused on the 
enhancement of heat conduction. Therefore, ultrasonic technology could be considered a feasible technique with which to speed up the heat transfer processes of dry-cured ham in a liquid medium and the conduction model employed could be useful to predict the ultrasound assisted heating behavior of sliced dry-cured ham.

\section{Acknowledgements}

The authors acknowledge the financial support from the "Spanish Ministerio de Economía y Competitividad (MINECO), Instituto Nacional de Investigación y Tecnología Agraria y Alimentaria (INIA)" in Spain, the European Regional Development Fund (ERDF 2014-2020) (Project RTA2013-00030-C03-02) and the PhD grant of M. Contreras from Universitat Politècnica de València.

\section{References}

Ahmad-Qasem, M. H., Cánovas, J., Barrajón-Catalán, E., Micol, V., Cárcel, J. A., \& GarcíaPérez, J. V. (2013). Kinetic and compositional study of phenolic extraction from olive leaves (var. Serrana) by using power ultrasound. Innovative Food Science and Emerging Technologies, 17, 120-129.

AOAC. (1997). Official Methods 950.46 and 991.36. In Official Methods of Analysis (sixteenth ed.)

Arnau, J., Guerrero, L., \& Gou, P. (1997). Effects of temperature during the last month of ageing and of salting time on dry-cured ham aged for six months. Journal of the Science of Food and Agriculture, 74, 193-198.

Cárcel, J. A., García-Pérez, J. V., Benedito, J., \& Mulet, A. (2012). Food process innovation through new technologies: Use of ultrasound. Journal of Food Engineering, 110, 200-207.

Chemat, F., Zill-E-Huma, \& Khan, M. K. (2011). Applications of ultrasound in food technology: Processing, preservation and extraction. Ultrasonics Sonochemistry, 18, 813835.

Contreras, M., Benedito, J., Bon, J., \& Garcia-Perez, J. V. (2018). Intensification of heat transfer during mild thermal treatment of dry-cured ham by using airborne ultrasound. Ultrasonics Sonochemistry, 41, 206-212.

de Prados, M., García-Pérez, J. V., \& Benedito, J. (2015). Non-destructive salt content prediction in brined pork meat using ultrasound technology. Journal of Food Engineering, $154,39-48$. 
Delgado, A. E., Zheng, L., \& Sun, D. W. (2009). Influence of ultrasound on freezing rate of immersion-frozen apples. Food and Bioprocess Technology, 2, 263-270.

Fan, K., Zhang, M., \& Mujumdar, A. S. (2017). Application of airborne ultrasound in the convective drying of fruits and vegetables: A review. Ultrasonics Sonochemistry, 39, 4757.

Fulladosa, E., Serra, X., Gou, P., \& Arnau, J. (2009). Effects of potassium lactate and high pressure on transglutaminase restructured dry-cured hams with reduced salt content. Meat Science, 82, 213-218.

Garau, M. C., Simal, S., Femenia, A., \& Rosselló, C. (2006). Drying of orange skin: Drying kinetics modelling and functional properties. Journal of Food Engineering, 75, 288-295.

Garcia-Garrido, J. A., Quiles-Zafra, R., Tapiador, J., \& Luque De Castro, M. D. (1999). Sensory and analytical properties of Spanish dry-cured ham of normal and defective texture. Food Chemistry, 67, 423-427.

Garcia-Gil, N., Santos-Garcés, E., Fulladosa, E., Laverse, J., Del Nobile, M. A., \& Gou, P. (2014). High pressure induces changes in texture and microstructure of muscles in drycured hams. Innovative Food Science and Emerging Technologies, 22, 63-69.

García-Pérez, J. V., Rosselló, C., Cárcel, J. A., De la Fuente, S., \& Mulet, A. (2006). Effect of air temperature on convective drying assisted by high power ultrasound. Defect and Diffusion Forum, 258-260, 563-574.

García-Rey, R. M., García-Garrido, J. A., Quiles-Zafra, R., Tapiador, J., \& Luque de Castro, M. D. (2004). Relationship between $\mathrm{pH}$ before salting and dry-cured ham quality. Meat Science, 67, 625-632.

Gondrexon, N., Cheze, L., Jin, Y., Legay, M., Tissot, Q., Hengl, N., Baup, S., Boldo, P., Pignon, F., \& Talansier, E. (2015). Intensification of heat and mass transfer by ultrasound: Application to heat exchangers and membrane separation processes. Ultrasonics Sonochemistry, 25, 40-50.

Gou, P., Morales, R., Serra, X., Guàrdia, M. D., \& Arnau, J. (2008). Effect of a 10-day ageing at $30{ }^{\circ} \mathrm{C}$ on the texture of dry-cured hams processed at temperatures up to $18{ }^{\circ} \mathrm{C}$ in relation to raw meat $\mathrm{pH}$ and salting time. Meat Science, 80,1333-1339.

Holman, J. P. (1986). Heat transfer. McGraw-Hill.

Jadhav, D., B.N., R., Gogate, P. R., \& Rathod, V. K. (2009). Extraction of vanillin from vanilla pods: A comparison study of conventional soxhlet and ultrasound assisted extraction. Journal of Food Engineering, 93, 421-426. 
Legay, M., Gondrexon, N., Le Person, S., Boldo, P., \& Bontemps, A. (2011). Enhancement of heat transfer by ultrasound: Review and recent advances. International Journal of Chemical Engineering, 2011, 1-17.

Legay, M., Le Person, S., Gondrexon, N., Boldo, P., \& Bontemps, A. (2012). Performances of two heat exchangers assisted by ultrasound. Applied Thermal Engineering, 37, 60-66.

Lespinard, A. R., Bon, J., Cárcel, J. A., Benedito, J., \& Mascheroni, R. H. (2015). Effect of ultrasonic-assisted blanching on size variation, heat transfer, and quality parameters of mushrooms. Food and Bioprocess Technology, 8, 41-53.

Li, B., \& Sun, D. W. (2002). Effect of power ultrasound on freezing rate during immersion freezing of potatoes. Journal of Food Engineering, 55, 277-282.

Masselin, I., Chasseray, X., Durand-Bourlier, L., Lainé, J. M., Syzaret, P. Y., \& Lemordant, D. (2001). Effect of sonication on polymeric membranes. Journal of Membrane Science, 181, 213-220.

Miles, C. A., Morley, M. J., \& Rendell, M. (1999). High power ultrasonic thawing of frozen foods. Journal of Food Engineering, 39, 151-159.

Morales, R., Arnau, J., Serra, X., Guerrero, L., \& Gou, P. (2008). Texture changes in dry-cured ham pieces by mild thermal treatments at the end of the drying process. Meat Science, 80 , 231-238.

Musielak, G., Mierzwa, D., \& Kroehnke, J. (2016). Food drying enhancement by ultrasound - A review. Trends in Food Science and Technology, 56, 126-141.

Ozuna, C., Cárcel, J. A., Walde, P. M., \& Garcia-Perez, J. V. (2014). Low-temperature drying of salted cod (Gadus morhua) assisted by high power ultrasound: Kinetics and physical properties. Innovative Food Science and Emerging Technologies, 23, 146-155.

Park, K. J., Vohnikova, Z., \& Brod, F. P. R. (2002). Evaluation of drying parameters and desorption isotherms of garden mint leaves (Mentha crispa L.). Journal of Food Engineering, 51, 193-199.

Piyasena, P., Mohareb, E., \& McKellar, R. C. (2003). Inactivation of microbes using ultrasound: A review. International Journal of Food Microbiology, 87, 207-216.

Pohlman, F. W., Dikeman, M. E., Zayas, J. F., \& Unruh, J. A. (1997). Effects of Ultrasound and Convection Cooking to Different End Point Temperatures on Cooking Characteristics, Shear Force and Sensory Properties, Composition, and Microscopic Morphology of Beef Longissimus and Pectoralis Muscles. Journal of Animal Science, 75, 386-401.

Rodríguez, Ó., Eim, V., Rosselló, C., Femenia, A., Cárcel, J. A., \& Simal, S. (2018). 
Application of power ultrasound on the convective drying of fruits and vegetables: effects on quality. Journal of the Science of Food and Agriculture, 98, 1660-1673.

Ruiz-Ramírez, J., Arnau, J., Serra, X., \& Gou, P. (2006). Effect of pH24, NaCl content and proteolysis index on the relationship between water content and texture parameters in biceps femoris and semimembranosus muscles in dry-cured ham. Meat Science, 72, 185194.

Santacatalina, J. V., Contreras, M., Simal, S., Cárcel, J. A., \& Garcia-Perez, J. V. (2016a). Impact of applied ultrasonic power on the low temperature drying of apple. Ultrasonics Sonochemistry, 28, 100-109.

Santacatalina, J. V., Guerrero, M. E., Garcia-Perez, J. V., Mulet, A., \& Cárcel, J. A. (2016b). Ultrasonically assisted low-temperature drying of desalted codfish. LWT - Food Science and Technology, 65, 444-450.

Schivazappa, C., Degni, M., Nanni Costa, L., Russo, V., Buttazzoni, L., \& Virgili, R. (2002). Analysis of raw meat to predict proteolysis in Parma ham. Meat Science, 60, 77-83.

Singh, R. P. (1982). Thermal diffusivity in food processing. Food Technology, 36, 87-91.

Tiwari, B. K. (2015). Ultrasound: A clean, green extraction technology. TrAC - Trends in Analytical Chemistry, 71, 100-109.

Zheng, L., \& Sun, D. W. (2006). Innovative applications of power ultrasound during food freezing processes - A review. Trends in Food Science and Technology, 17, 16-23. 

Ultrasonic - Sonochemistry, 2018, 41, 206-212.

Intensification of heat transfer during mild thermal treatment of dry-cured ham by using airborne ultrasound

Marina Contreras, Jose Benedito, Jose Bon, Jose Vicente Garcia-Perez

Grupo de Análisis y Simulación de Procesos Agroalimentarios (ASPA). Departamento de Tecnología de Alimentos. Universitat Politècnica de València. Camí de Vera s/n, Valencia (46022), Spain. 



\title{
Intensification of heat transfer during mild thermal treatment of dry-cured ham by using airborne ultrasound
}

\begin{abstract}
The application of power ultrasound $(\mathrm{PuS})$ could be used as a novel technology with which to intensify thermal treatments using hot air. Mild thermal treatments have been applied to improve the soft texture of dry-cured ham caused by defective processing. In this regard, the aim of this study was to assess the kinetic intensification linked to the application of airborne $\mathrm{PuS}$ in the mild thermal treatment using hot air of dry-cured ham. For this purpose, vacuum packed cylindrical samples $(2.52 \pm 0.11 \mathrm{~cm}$ in diameter and $1.90 \pm 0.14 \mathrm{~cm}$ in height $)$ of dry-cured ham were heated using hot air at different temperatures $\left(40,45,50^{\circ} \mathrm{C}\right)$ and air velocities $(1,2$, $3,4,6 \mathrm{~m} / \mathrm{s})$ with $(22.3 \mathrm{kHz}, 50 \mathrm{~W})$ and without PuS application. Heat transfer was analyzed by considering that it was entirely controlled by conduction and the apparent thermal diffusivity was identified by fitting the model to the heating kinetics. The obtained results revealed that $\mathrm{PuS}$ application sped up the heat transfer, showing an increase in the apparent thermal diffusivity (up to 37\%). The improvement in the apparent thermal diffusivity produced by PuS application was greater at high temperatures $\left(50^{\circ} \mathrm{C}\right)$ but negligible at high air velocities $(6 \mathrm{~m} / \mathrm{s})$. Heating caused an increase in the hardness and elasticity of dry-cured ham, which would correct ham pastiness defects, while the influence of PuS on such textural parameters was negligible.
\end{abstract}

Keywords: temperature; air velocity; ultrasound; heat transfer; modelling. 


\section{Introduction}

Dry-cured ham is highly appreciated by consumers due to its high quality, which is defined by a typical flavor, color, composition and texture (Ventanas \& Andrés, 2001). Therefore, texture is one of the most important sensory attributes of dry-cured ham, which greatly influences consumer acceptability (Morales et al., 2007). Two of the main textural problems in this product are excessive softness and pastiness (García-Rey et al., 2004; Virgili et al., 1995). These defects are related to a short processing time and low salt content, which are linked to the fact that companies rush to obtain the final product in the shortest possible time as well as to the tendency to reduce the final $\mathrm{NaCl}$ content according to the Global Strategy on Diet, Physical Activity and Health of the World Health Organization (WHO).

One of the strategies reported in the literature to correct the softness and pastiness of dry-cured ham, obtaining a harder texture, has been the use of mild thermal treatments. Morales et al. (2008) evaluated textural changes when submitting small, packaged dry-cured ham cross sections to $30{ }^{\circ} \mathrm{C}$ for $168 \mathrm{~h}$, observing that the softness decreased in Biceps femoris muscles while the texture in the Semimembranosus muscle and other physicochemical parameters, such as moisture, water activity and proteolytic index, remained unaffected. On the other hand, Gou et al. (2008) investigated the effect of a 10-day ageing process at $30^{\circ} \mathrm{C}$ on the soft texture of whole dry-cured ham pieces elaborated with different raw meat $\mathrm{pHs}$ and salting times. These authors reported that the ageing at temperatures of around $30^{\circ} \mathrm{C}$ could be useful for the purposes of decreasing the incidence of soft textures in dry-cured ham without affecting the product flavor. However, the mild thermal treatments tested by Morales et al. (2008) and Gou et al. (2008) required a long processing time, which is a significant drawback for industrial applications. Therefore, temperatures higher than $30^{\circ} \mathrm{C}$ should be tested to evaluate whether the expected textural changes can be produced in shorter times. However, higher temperatures could damage quality characteristics of dry-cured ham, such as flavor and appearance. To minimize these unfavorable effects, the use of more efficient heat transfer processes should be investigated.

Process intensification aims to improve traditional technologies and to develop new ones to achieve a higher yield, a notable reduction in equipment size, lower energy usage and increased product quality and processing safety (Benali \& Kudra, 2010; Mason et al., 1996). Among other new technologies, power ultrasound (PuS) emerges as a feasible technology for improving heat transfer processes. Legay et al. (2011) reported an exhaustive review of ultrasonic applications in liquid medium to improve heat transfer processes, such as boiling, melting and solidification. Basically, the cavitation and microagitation produced by ultrasound in the liquid medium are the responsible of reducing heat transfer resistance by increasing fluid turbulence. In addition, the application of $\mathrm{PuS}$ in fluids provokes an increase in its temperature due to cavitation and molecule friction (Ashokkumar, 2011; Chandrapala et al., 2012), which 
also accelerates the heating processes. Thus, ultrasonic water baths or sonotrode-type systems could be useful for the heating intensification necessary to reduce the soft texture of dry-cured hams, by immersing the packaged samples in a liquid medium, such as water. However, at industrial level, the use of hot water would involve large amounts of energy and water consumption. Furthermore, these systems could lead to the contamination of samples, since the plastic bags where dry-cured ham pieces are packaged could be perforated due to the water micro jets produced by ultrasonic cavitation. In order to overcome liquid media handicaps, hot air treatments could be an interesting alternative for correcting the soft texture of cured hams through mild thermal treatments. Heat transfer in air medium is limited by its lower external convection coefficient compared to liquid medium. Thereby, the application of airborne PuS could be considered a relevant strategy for process intensification. Multiple applications of ultrasonically-assisted heating in liquid media exist (Chemat et al., 2011), but no references have been found in the literature of using airborne PuS for heating applications in food materials. Most of the references found in the literature pertaining to the use of airborne PuS in food applications refer to mass transfer processes and particularly to food drying. In this regard, Garcia-Perez et al. (2013) already reported the feasibility of using PuS for improving heat transfer during the hot air drying of grape stalks. Similarly, Bantle \& Hanssler (2013) confirmed that high intensity airborne ultrasound is a promising technology for enhancing the heat transfer coefficient and thus, reducing the drying time of salted codfish convective drying. In the same way, silica gel regeneration, which is essentially a drying process, has been improved by ultrasound application due to the fact that it leads to a more uniform energy distribution and, hence, achieves a greater efficiency of utilization (Yao, 2016; Zhang et al., 2010).

Therefore, the main aim of this study was to assess the kinetic improvement linked to the application of airborne PuS in the hot air mild thermal treatment of dry-cured ham. In addition, the influence of the thermal treatment in the textural changes induced in the hams was also analyzed.

\section{Materials and methods}

\subsection{Raw material}

For the heating experiments, dry-cured ham slices from Large White breed pigs provided by the IRTA-Research\&Technology-Food\&Agriculture Institute (Monells, Girona) were used. From the slices, cylindrical samples were taken from the Biceps femoris and Semimembranosus muscles using a household tool. Each cylinder $(2.52 \pm 0.11 \mathrm{~cm}$ in diameter and $4.00 \pm 0.14 \mathrm{~cm}$ in height) was split into two equal size portions (half of the height), one half was used as control and the other half was vacuum packaged (PA/PE bags with water 
permeability smaller than $5 \mathrm{~g} / \mathrm{m}^{2} / \mathrm{d}$ at $23{ }^{\circ} \mathrm{C}$ and $85 \%$ RH, Sacoliva ${ }^{\circledR}$ S.L., Spain). Packaged ham cylinders were kept in refrigeration $\left(4 \pm 2{ }^{\circ} \mathrm{C}\right)$ until heating experiments were performed.

\subsection{Heating treatments}

Heating experiments were carried out in an air-forced heater (Figure 1), which was described in detail by Riera et al. (2011). The air flowed from the fan to the heating chamber, passing through an electrical resistance that warmed it up to the desired temperature. Air velocity and temperature were measured in a PID control loop by an anemometer (Wilh. Lambrecht GmbH, Göttingen, Germany) and a Pt-100 sensor, respectively. The heating chamber consisted of a vibrating aluminum cylinder attached to a piezoelectric transducer $(22.3$ $\mathrm{kHz}$ ). Samples were placed within the vibrating cylinder hung on a sample holder, similar to that used by Garcia-Perez et al. (2006a). In the PuS experiments, ultrasonic waves were transmitted from the walls of the heating chamber to the air, finally reaching the sample.

Two different sets of experiments were carried out to test the influence of the air temperature (\#1) and flow rate (\#2).

- The first set $(\# 1)$ was conducted at different air temperatures $\left(40,45,50{ }^{\circ} \mathrm{C}\right)$, constant air velocity $(2 \mathrm{~m} / \mathrm{s})$ and without (AIR, $0 \mathrm{~W}$ ) and with (AIR+PuS, $50 \mathrm{~W}) \mathrm{PuS}$ application. The temperature range was chosen in order to accelerate textural changes without imparting cooking flavors and appearance to the ham.

- The second set (\#2) was performed at different air velocities $(1,2,3,4,6 \mathrm{~m} / \mathrm{s})$, constant air temperature $\left(50^{\circ} \mathrm{C}\right)$ and without $(0 \mathrm{~W})$ and with $(50 \mathrm{~W}) \mathrm{PuS}$ application.

Heating treatments were finalized when the temperature in the center of the sample (Target temperature, $\mathrm{Tt}$ ) was $5{ }^{\circ} \mathrm{C}$ under the air temperature. Every different heating condition was tested in triplicate at least. Thus, the total number of experiments carried out in the first set was 18 (3 temperatures x 2 ultrasound application $\times 3$ replicates) and 30 in the second set ( 5 air velocities $\mathrm{x} 2$ ultrasound application $\mathrm{x} 3$ replicates). The evolution of the temperature in all the experiments was monitored in the center of the sample by using a type-T thermocouple (Class I, TCDirect, Spain). Furthermore, the air temperature was measured at the inlet and outlet of the heating chamber by using a type-K thermocouple (TCDirect, Spain). 


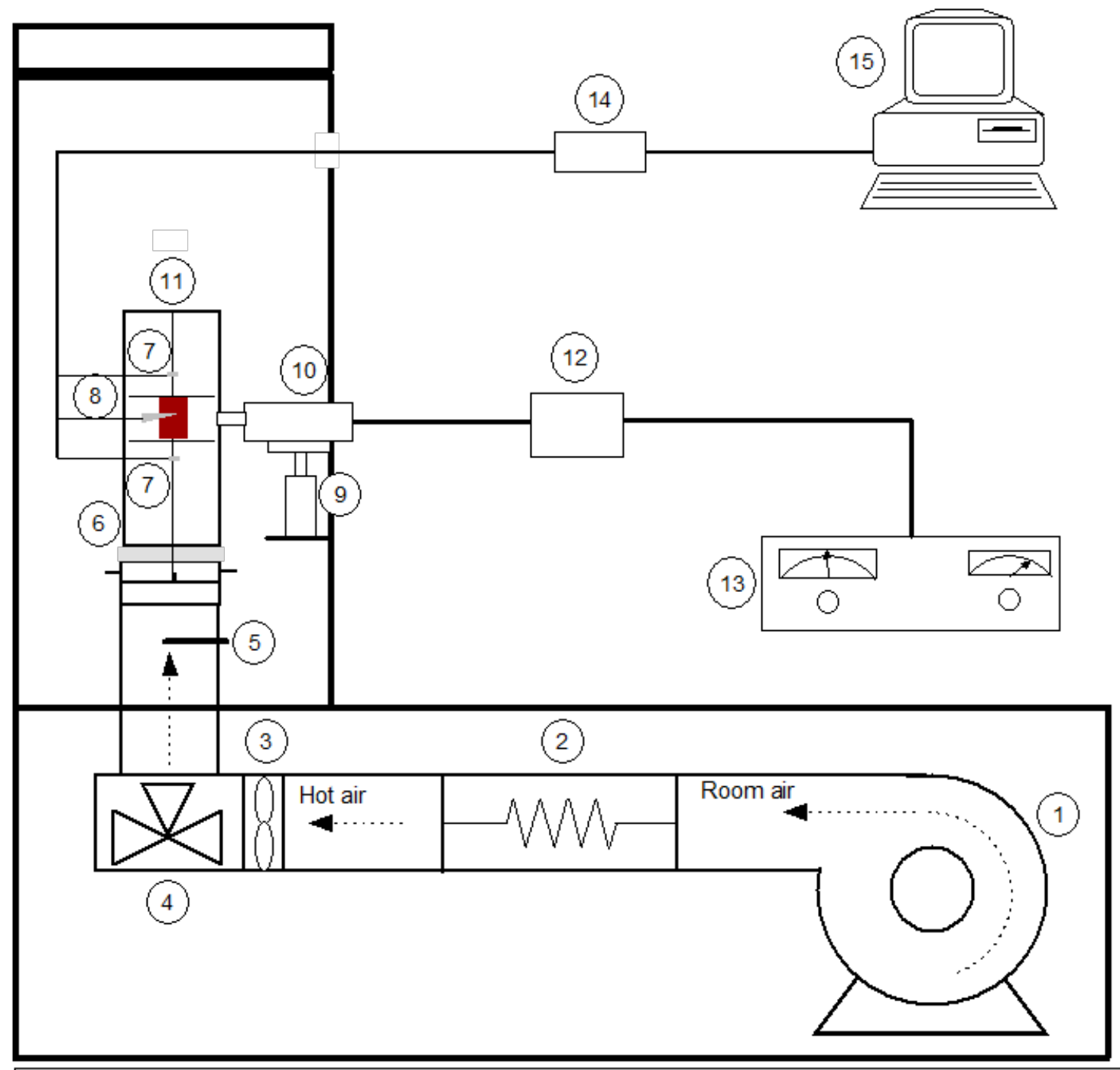

1. Fan, 2. Electrical resistances, 3. Anemometer, 4. 3-Way valve, 5. Pt-100, 6. Heating chamber, 7. Type-K thermocouples, 8. Type-T thermocouple, 9. Pneumatic moving arms, 10. Ultrasonic transducer, 11. Vibrating cylinder, 12. Impedance matching unit, 13. High power ultrasonic generator, 14. Data logger, 15. PC

Figure 1. Scheme of ultrasonically assisted air-forced heater.

\subsection{Modelling of the heating kinetics}

Modelling was used to quantify the effect of air temperature, air velocity and PuS on the kinetics of the heating process. For that purpose, a mathematical model was used that considered heat transfer to be entirely controlled by conduction, assuming that the sample surface temperature instantaneously reached equilibrium with the air temperature. The material was supposed to be homogeneous and isotropic, with constant effective thermal diffusivity. In addition, due to the cylindrical shape, the samples of dry-cured ham were considered as a finite cylinder as regards heat transfer. Thus, the conduction equation (Eq. 1) (Holman, 1986) used is written as follows: 


$$
\frac{T(x, r, t)-T_{\infty}}{T_{0}-T_{\infty}}=\left(2 \sum_{n=0}^{\infty} \frac{(-1)^{n}}{\beta_{n} L} e^{-\alpha \beta_{n}^{2} t} \cos \left(\beta_{n} x\right)\right)\left(2 \sum_{n=1}^{\infty} \frac{e^{-\alpha \lambda_{n}^{2} t}}{\lambda_{n} R J_{1}\left(\lambda_{n} R\right)} J_{0}\left(\lambda_{n} r\right)\right)
$$

where $T_{0}$ is the initial temperature $\left({ }^{\circ} \mathrm{C}\right)$ of dry-cured ham, $T_{\infty}$ is the air heating medium temperature ( $\left.{ }^{\circ} \mathrm{C}\right), \beta_{n}$ are the eigenvalues calculated as $\beta_{n}=(2 n+1) \frac{\pi}{2 L}, L$ is the half-thickness of the cylinder $(\mathrm{m}), \alpha$ is the apparent thermal diffusivity $\left(\mathrm{m}^{2} / \mathrm{s}\right), t$ is the time $(\mathrm{s}), x$ is the axial direction (m), $\lambda_{n}$ are the eigenvalues calculated as $\lambda_{n} / J_{0}\left(\lambda_{n} R\right)=0, R$ is the cylinder radius $(\mathrm{m}), J_{v}$ is the Bessel function of the first kind of order $v$ and $r$ is the radial direction (m). The model was solved by taking (i) only the first term or (ii) the first 50 terms of both summations. The aim behind this strategy is to check the accuracy of both strategies in the estimation of the thermal diffusivity and the accuracy of fit of the model (Ayadi et al., 2009).

In Eq. 1, thermal diffusivity is assumed to be an apparent kinetic parameter, which includes not only conduction phenomena, but also others linked to effects that were not considered, such as convection and radiation from the vibrating cylinder walls. Apparent thermal diffusivity $(\alpha)$ was identified by fitting Eq. 1 to heating kinetics, defined as the evolution of the temperature in the center of the cylinder, $\mathrm{T}_{(0,0, \mathrm{t})}$. The identification was carried out by minimizing the summatory of squared differences between the experimental and calculated temperature. The Solver optimization tool available in Microsoft Excel 2016 was used for this purpose. The goodness of the fit was assessed by calculating the percentages of explained variance (VAR, Eq. 2) and the mean relative error (MRE, Eq. 3),

$$
\begin{aligned}
& \operatorname{VAR}(\%)=\left[1-\frac{\mathrm{S}_{\mathrm{xy}}^{2}}{\mathrm{~S}_{\mathrm{y}}^{2}}\right] \cdot 100 \\
& \operatorname{MRE}(\%)=\frac{\sum_{\mathrm{i}=1}^{\mathrm{N}} \frac{\left|\mathrm{T}_{\mathrm{ei}}-\mathrm{T}_{\mathrm{ci}}\right|}{\mathrm{T}_{\mathrm{ei}}}}{\mathrm{N}} \cdot 100
\end{aligned}
$$

where $S_{x y}$ and $S_{y}$ are the standard deviation of the estimation and the sample, respectively, $T_{e i}$ and $T_{c i}$ are the experimental and calculated temperature and $N$ is the number of experimental data.

\subsection{Textural properties}

The textural properties of dry-cured ham cylinders from the first set of experiments (\#1) were measured using a TA-XT2 texturometer (SMS, Godalming, UK) provided with a load cell 
of $50 \mathrm{~kg}$. Stress-relaxation tests were carried out at constant temperature $\left(4 \pm 1^{\circ} \mathrm{C}\right)$ using a flat 75 $\mathrm{mm}$ diameter aluminum plunger (SMS P/75). The samples were compressed to $25 \%$ of their original height parallel to the fiber bundle direction at a crosshead speed of $1 \mathrm{~mm} / \mathrm{s}$ and, afterwards, the probe was held for $90 \mathrm{~s}$ to monitor relaxation. The experimental data were recorded and processed with Exponent Lite 6.1.4.0 software (SMS, Godalming, UK). Thus, hardness was computed from the force versus time profiles as the maximum force achieved during compression, and the level of force decay $Y_{t}$ logged during relaxation was calculated as follows:

$$
Y_{t}=\frac{F_{0}-F_{t}}{F_{0}}
$$

where $F_{0}$ is the maximum force during compression $(\mathrm{N})$ and $F_{t}$ is the force recorded after $\mathrm{t}$ seconds of relaxation. $Y$ was calculated at $2 \mathrm{~s}$ of the relaxation period and at the end of the stress-relaxation test $(90 \mathrm{~s})$. In order to quantify the changes in the texture of dry-cured hams after the heating treatment, the difference between control and treated samples was calculated for every textural parameter.

\subsection{Statistical analysis}

In order to evaluate if the operating conditions studied (temperature, air velocity and $\mathrm{PuS}$ ) had a significant influence on the thermal diffusivity, an analysis of variance (ANOVA) $(\mathrm{p}<0.05)$ was carried out, and the least significant difference (LSD) intervals were estimated using the statistical package Statgraphics Centurion XVI (Statpoint Technologies Inc., Warrenton, VA, USA). ANOVAs were performed considering the thermal diffusivity as a dependent variable and the air temperature, air velocity and the heating treatment (AIR or $\mathrm{AIR}+\mathrm{PuS}$ ), as well as their interactions, as factors. Additionally, the influence of the heating conditions on the ham textural properties were also compared by means of ANOVA and LSD intervals.

\section{Results and discussion}

\subsection{Heating kinetics}

\subsubsection{Effect of air temperature}

The heating kinetics of packaged dry-cured ham cylinders at different air temperatures are shown in Figure 2. The common effect of air temperature on air-forced heating for foodstuffs is illustrated in the aforementioned figure; so, as extensively described in the 
literature (Hernández et al., 2008; Hii et al., 2016), the higher the air temperature, the higher the product temperature for a particular treatment time. Additionally, air temperature had a relevant effect on the necessary heating time, which, as mentioned in section 2.2, was defined as what was required to reach the target temperature in the center of the product $\left(5^{\circ} \mathrm{C}\right.$ less than the air temperature). As can be observed in AIR experiments, the higher the air temperature used, the longer the heating time (Figure 2, A). Therefore, heating times ranged from $19 \pm 0.8 \mathrm{~min}$ at $40{ }^{\circ} \mathrm{C}$ to $25 \pm 0.9 \mathrm{~min}$ at $50{ }^{\circ} \mathrm{C}$. In this context, the application of PuS during dry-cured ham heating partially modified the effect of air temperature on heating kinetics. Thus, in AIR+PuS experiments, the heating time was similar at every temperature tested (Figure 2, B). This evidenced a larger improvement in the heat transfer as the temperature increased. It should be mentioned that the use of PuS had no significant ( $>>0.05)$ influence on the temperature of the output air of the heating chamber, which demonstrates that no additional air heating was produced by the ultrasonic field.

If AIR and AIR+PuS heating kinetics are compared (Figure 3), the shortening of the heating time produced by ultrasonic application was of only $15 \%$ at $40{ }^{\circ} \mathrm{C}$, while at $50^{\circ} \mathrm{C}$ it was $31 \%$ shorter, which showed the effect of the interaction between temperature and the application of PuS. Similarly, previous results reported for other airborne PuS applications found that ultrasound had a greater effect on mass transfer at high than at low air temperatures. On the contrary, in hot air drying, Garcia-Perez et al. (2006b) suggested that the ratio of the energy provided when PuS was applied at high temperatures was lower than at low temperatures due to the already existing high thermal energy in the medium and, consequently, the effect on water transport linked to ultrasound was reduced. In heating experiments, the thermal energy gradient produced by the temperature difference is the driving force of the heat flow, which increases as the temperature rises. Therefore, any improvement in heat transfer coefficients will have a bigger impact on the heat flow at high than at low temperatures. This could explain the fact that $\mathrm{PuS}$ has a greater effect on heating treatments at high than at low air temperatures. 

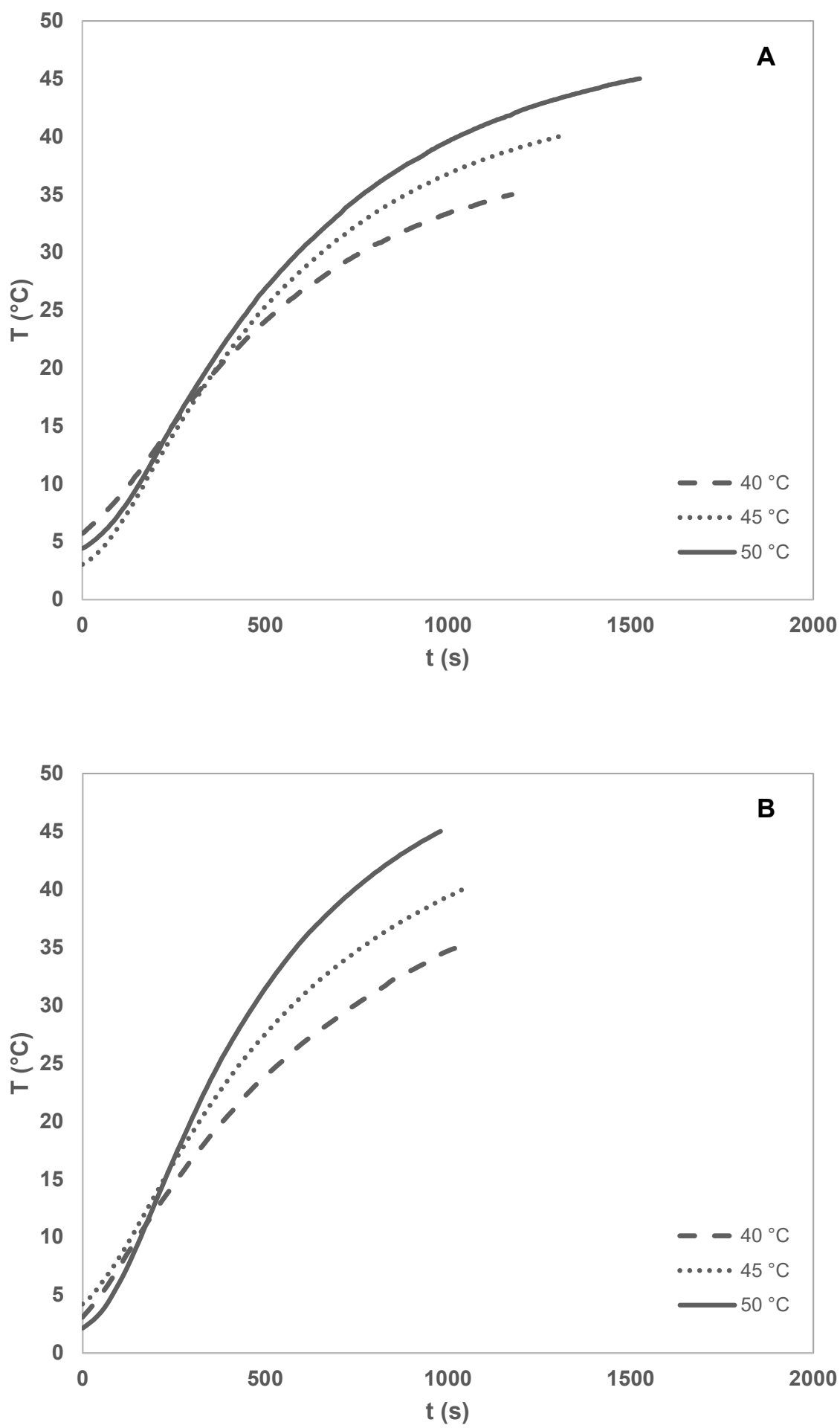

Figure 2. Heating kinetics of dry-cured ham at different air temperatures $\left(40,45\right.$, and $\left.50{ }^{\circ} \mathrm{C}\right)$ (constant air velocity of $2 \mathrm{~m} / \mathrm{s}$ ). A: without PuS application (AIR). B: with PuS application (AIR+PuS). 


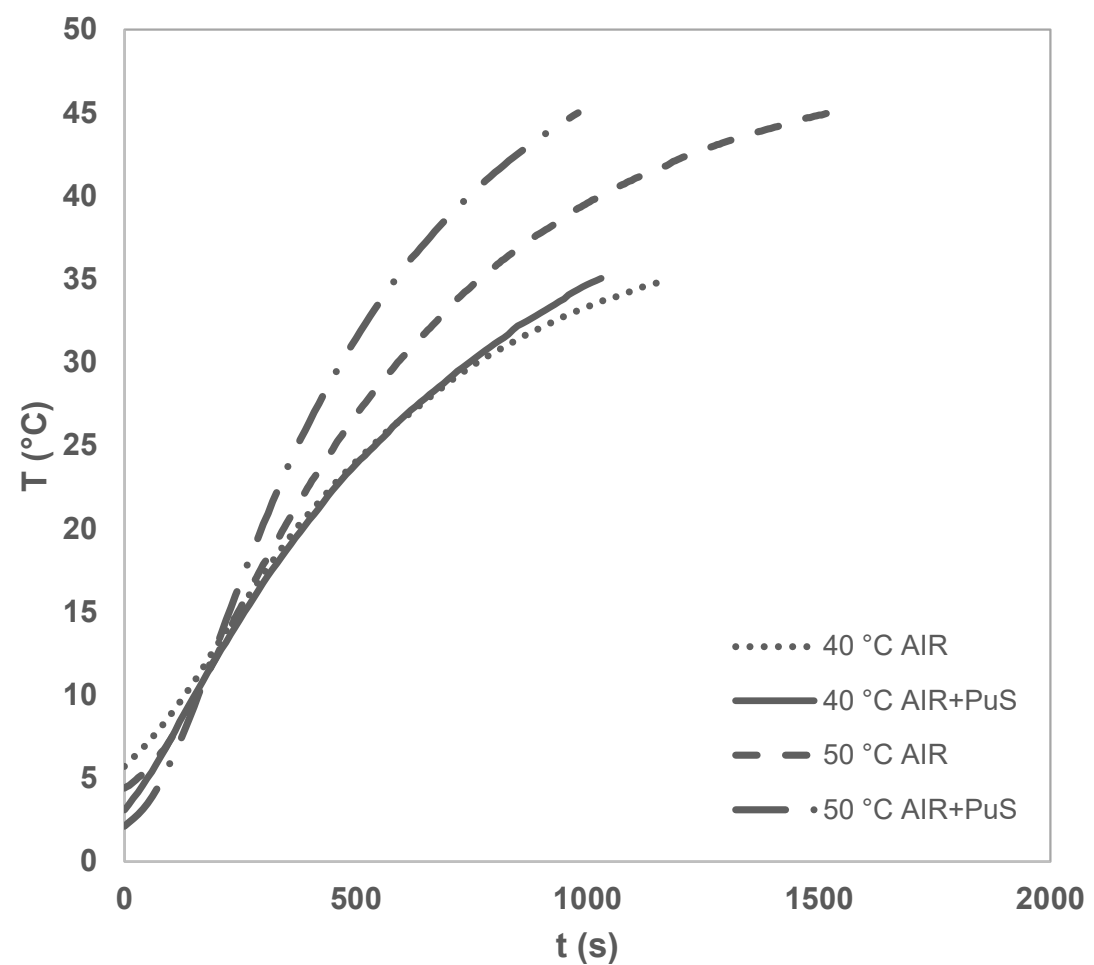

Figure 3. Heating kinetics of dry-cured ham at different air temperatures $\left(40\right.$ and $\left.50{ }^{\circ} \mathrm{C}\right)$ without (AIR) and with (AIR+PuS) PuS application.

\subsubsection{Effect of the air velocity}

The heating kinetics of packaged dry-cured ham were carried out at five different air velocities $(1,2,3,4$ and $6 \mathrm{~m} / \mathrm{s})$ and $50^{\circ} \mathrm{C}$. In AIR experiments, it was found that the higher the air velocity, the faster the heating kinetics (Figure 4, A). Thus, the heating time was shortened from $38 \pm 5$ to $12 \pm 1 \mathrm{~min}$ when the air velocity increased from 1 to $6 \mathrm{~m} / \mathrm{s}$. This might occur because the increase in air velocity led to a reduction in the boundary layer thickness and, consequently, to a decrease in the external resistance to heat transfer (Akpinar \& Toraman, 2016; Ghisalberti \& Kondjoyan, 1999; Santacatalina et al., 2016). 

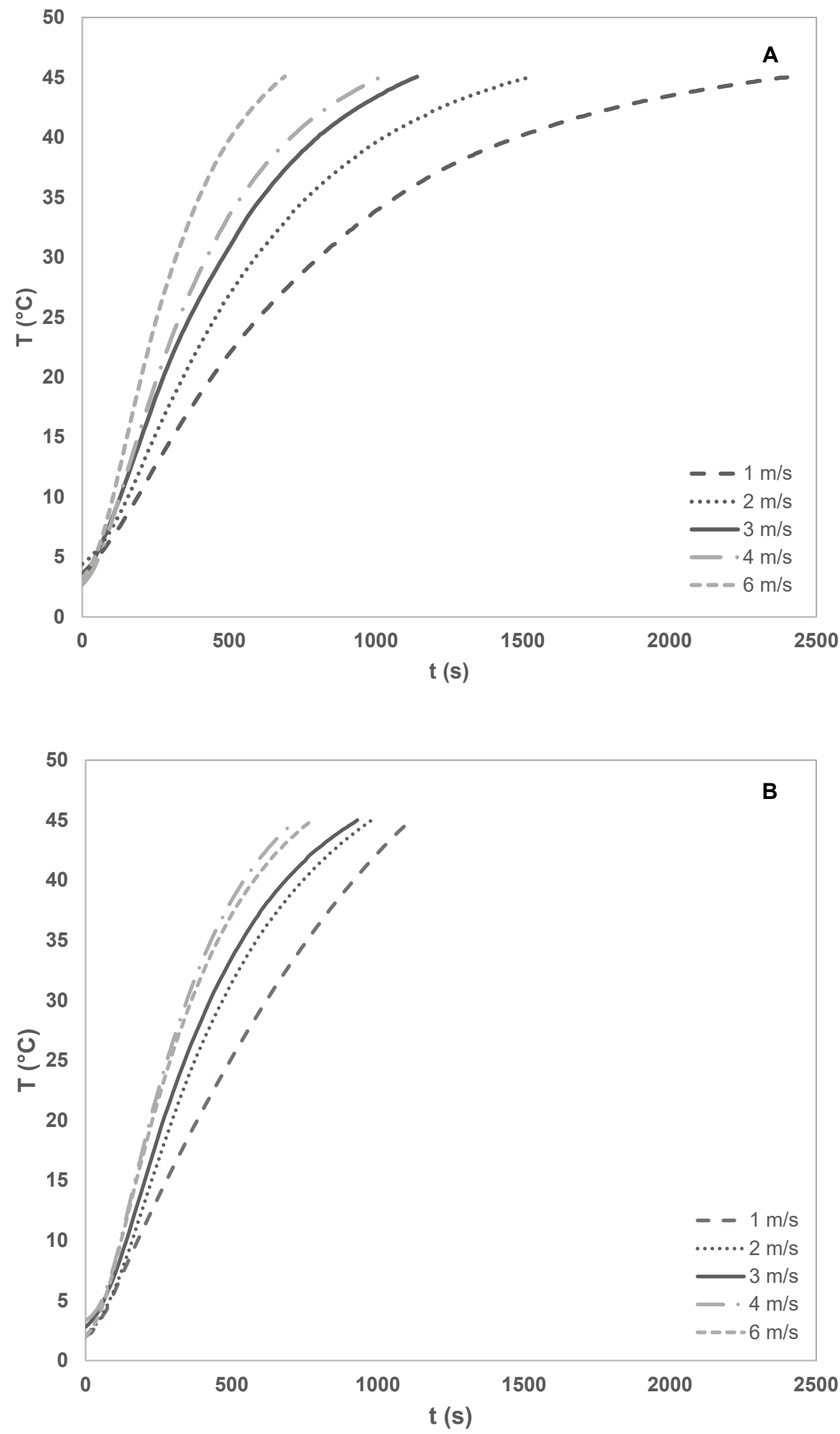

Figure 4. Heating kinetics of dry-cured ham at different air velocities $(1,2,3,4$ and $6 \mathrm{~m} / \mathrm{s})$ (constant air temperature of $50^{\circ} \mathrm{C}$ ). A: without PuS application (AIR). B: with PuS application (AIR+PuS). 
The application of PuS buffered the effect of the air velocity on the heating kinetics. As observed in Figure 4 B, fairly similar heating times were found for air velocities higher than 1 $\mathrm{m} / \mathrm{s}$. This fact revealed a meaningful effect of ultrasound on external resistance to heat transfer. Yao et al. (2015) reported that the mechanical vibration induced by PuS reduced the thickness of the boundary layer on the gas-solid interface, lessening the external resistance to heat transfer. For process intensification purposes, AIR $+\mathrm{PuS}$ experiments were only markedly faster than AIR ones at low air velocities; so, the ultrasonic effect was blurred as the air velocity increased. Thus, for example, the heating times of the experiments carried out at $1 \mathrm{~m} / \mathrm{s}$ were $38 \pm 5$ and $20 \pm 5$ minutes for AIR and AIR+PuS, respectively; whereas at $6 \mathrm{~m} / \mathrm{s}$, the heating time in AIR experiments was $12 \pm 1$ contrasted with the $15 \pm 3$ minutes in AIR $+\mathrm{PuS}$ ones. This might be ascribed to some facts; firstly, to the negative effect of high air flow rates on the ultrasonic field, which would reduce the acoustic energy available at high air velocities, such as was suggested by Garcia-Perez et al. (2006a). Secondly, the negligible effect of ultrasound at high air velocities could be explained by assuming that there is no effect of ultrasound on heat conduction, its influence being restricted to the heat convection. This has been reported in liquid media applications where cavitation (Povey \& Mason, 1998) increases the liquid temperature in the interface apart from rising turbulence and pressure variations (Alarcon-Rojo et al., 2015), leading to a reduction in the external resistance to heat transfer. Modelling will help to gain knowledge about the effect of PuS on heat transfer, as well as the predominant phenomena (conduction or convection).

\subsection{Modelling of the heating kinetics}

The heating kinetics of dry-cured ham cylinders processed at different temperatures (40, 45 and $50^{\circ} \mathrm{C}$ ), air velocities $(1,2,3,4$ and $6 \mathrm{~m} / \mathrm{s})$, and without and with PuS application were modelled using Eq. 1, described in section 2.3. Table 1 shows the thermal diffusivity and statistical parameters computed when the conduction model was solved by taking the first 50 terms of both summations. The conduction heat transfer model considered did not provide an optimal fit of the experimental data since the explained variance percentages were under $99 \%$ and mean relative errors over $10 \%$ in every case (Table 1). A very poor fit was obtained when only the first term of both summations was considered, which involved an average increase in the MRE up to values close to $30 \%$ and a reduction in the VAR down to figures close to $50 \%$. Statistical data shown in Table 1 illustrate that assumptions considered in the model did not adequately match the process behavior. Therefore, the hypothesis that assumes that heat transfer was entirely controlled by conduction, neglecting any resistance linked to heat convection in the interface, did not correspond to the process characteristics. As presented in the previous section, the influence of heat convection should not be neglected due to the fact that the increase in the air velocity involved the shortening of the heating time, which was especially meaningful in 
AIR experiments. As a consequence, the apparent thermal diffusivity identified by fitting Eq. 1 to the heating kinetics should be considered an overall heat transport coefficient including the kinetic coefficients linked to both the external and the internal resistance to the heat transfer. Therefore, more realistic models have to be developed considering both internal and external heat transfer resistance. The resolution of joint convection+conduction models involves larger computing requirements and should be the subject of future studies since modelling was not the main aim of the present piece.

Table 1. Apparent thermal diffusivity $(\alpha)$ and statistical parameters obtained from modelling of heating kinetics of dry-cured ham at different air temperatures $\left(40,45\right.$ and $50{ }^{\circ} \mathrm{C}$ ) (constant air velocity of $2 \mathrm{~m} / \mathrm{s}$ ), and at different air velocities $(1,2,3,4$ and $6 \mathrm{~m} / \mathrm{s}$ ) (constant air temperature of 50 ${ }^{\circ} \mathrm{C}$ ), without (AIR) and with (AIR+PuS) PuS application. VAR (\%) is the percentage of explained variance and MRE (\%) the percentage of mean relative error.

\begin{tabular}{|c|c|c|c|c|}
\hline & & $\begin{array}{l}\text { Apparent thermal } \\
\text { diffusivity }(\alpha) \\
\left(\mathrm{x} 10^{-8} \mathbf{m}^{2} / \mathbf{s}\right)\end{array}$ & VAR (\%) & MRE (\%) \\
\hline \multirow{3}{*}{ AIR } & $40^{\circ} \mathrm{C}$ & 4.1 & 91.3 & 12.6 \\
\hline & $45^{\circ} \mathrm{C}$ & 4.2 & 93.9 & 16.4 \\
\hline & $50{ }^{\circ} \mathrm{C}$ & 4.2 & 94.3 & 18.1 \\
\hline \multirow{3}{*}{$\mathrm{AIR}+\mathrm{PuS}$} & $40^{\circ} \mathrm{C}$ & 4.3 & 92.9 & 12.7 \\
\hline & $45^{\circ} \mathrm{C}$ & 4.8 & 92 & 14.5 \\
\hline & $50^{\circ} \mathrm{C}$ & 5.8 & 94.6 & 15.5 \\
\hline \multirow{5}{*}{ AIR } & $1 \mathrm{~m} / \mathrm{s}$ & 3.4 & 91.7 & 17.5 \\
\hline & $2 \mathrm{~m} / \mathrm{s}$ & 4.2 & 94.3 & 22.5 \\
\hline & $3 \mathrm{~m} / \mathrm{s}$ & 5.2 & 94.2 & 15.2 \\
\hline & $4 \mathrm{~m} / \mathrm{s}$ & 5.6 & 95.7 & 13.3 \\
\hline & $6 \mathrm{~m} / \mathrm{s}$ & 6.0 & 94.7 & 13.5 \\
\hline \multirow{5}{*}{$\mathbf{A I R}+\mathbf{P u S}$} & $1 \mathrm{~m} / \mathrm{s}$ & 4.1 & 93.5 & 14.2 \\
\hline & $2 \mathrm{~m} / \mathrm{s}$ & 5.8 & 94.6 & 15.5 \\
\hline & $3 \mathrm{~m} / \mathrm{s}$ & 5.9 & 96.8 & 11.9 \\
\hline & $4 \mathrm{~m} / \mathrm{s}$ & 6.2 & 97.7 & 12.1 \\
\hline & $6 \mathrm{~m} / \mathrm{s}$ & 6.3 & 95.8 & 17.9 \\
\hline
\end{tabular}

In the interval of temperatures analyzed, the values of apparent thermal diffusivity obtained ranged from $4.1 \times 10^{-8} \mathrm{~m}^{2} / \mathrm{s}$ at $40{ }^{\circ} \mathrm{C}$ without $\mathrm{PuS}$ application to $5.8 \times 10^{-8} \mathrm{~m}^{2} / \mathrm{s}$ at $50{ }^{\circ} \mathrm{C}$ with PuS application. The use of only the first term of the summations in Eq. 1 leads to an underestimation of the thermal diffusivity, i.e. for AIR experiments at $40^{\circ} \mathrm{C}$; this approach reduces the thermal diffusivity from $4.1 \times 10^{-8}$ to $2.43 \times 10^{-8} \mathrm{~m}^{2} / \mathrm{s}$. Slightly lower values of thermal diffusivity were identified by Rinaldi et al. (2010) during pork loin cooking at $100^{\circ} \mathrm{C}\left(0.7 \times 10^{-8}\right.$ $\left.\mathrm{m}^{2} / \mathrm{s}\right)$ and $140{ }^{\circ} \mathrm{C}\left(4.1 \times 10^{-8} \mathrm{~m}^{2} / \mathrm{s}\right)$ and by Ayadi et al. (2009) while cooking turkey ham at $90{ }^{\circ} \mathrm{C}$ 
$\left(1.98 \times 10^{-8} \mathrm{~m}^{2} / \mathrm{s}\right)$. As can be observed in Figure 5, the apparent thermal diffusivity in AIR experiments was not affected by temperature. It seems to be consistent with the literature, since thermal diffusivity is a characteristic property of the material and should not be modified by air temperature if it does not lead to any textural-structural sample modification. However, the opposite behavior was observed in $\mathrm{AIR}+\mathrm{PuS}$ experiments, since the higher the air temperature, the higher the apparent thermal diffusivity; this was reflected in the ANOVA through the significant $(\mathrm{p}=0.0403)$ interaction between the factors, treatment type (AIR and AIR+PuS) and air temperature. In addition, the application of PuS led to an increase in the apparent thermal diffusivity at every temperature tested, compared to AIR treatments. In particular, the higher the temperature $\left(50^{\circ} \mathrm{C}\right)$, the greater the improvement in transport phenomena brought about by $\mathrm{PuS}$ application, achieving a ratio $\alpha_{A I R+P U S} / \alpha_{A I R}$ of 1.4 at $50^{\circ} \mathrm{C}$. The increase in the apparent thermal diffusivity could either be associated with the reduction in both internal and external resistance to heat transfer or merely with the reduction in the external one. As already mentioned (Yao et al., 2015), the main effects of ultrasound on external resistance to heat transfer could be linked to cavitation (Povey \& Mason, 1998), which increases the turbulence thus reducing the external resistance to heat transfer. Additionally, the compressions and expansions provoked by ultrasound in the solid may induce a possible increase in heat conduction mechanisms and, consequently, in the thermal diffusivity.

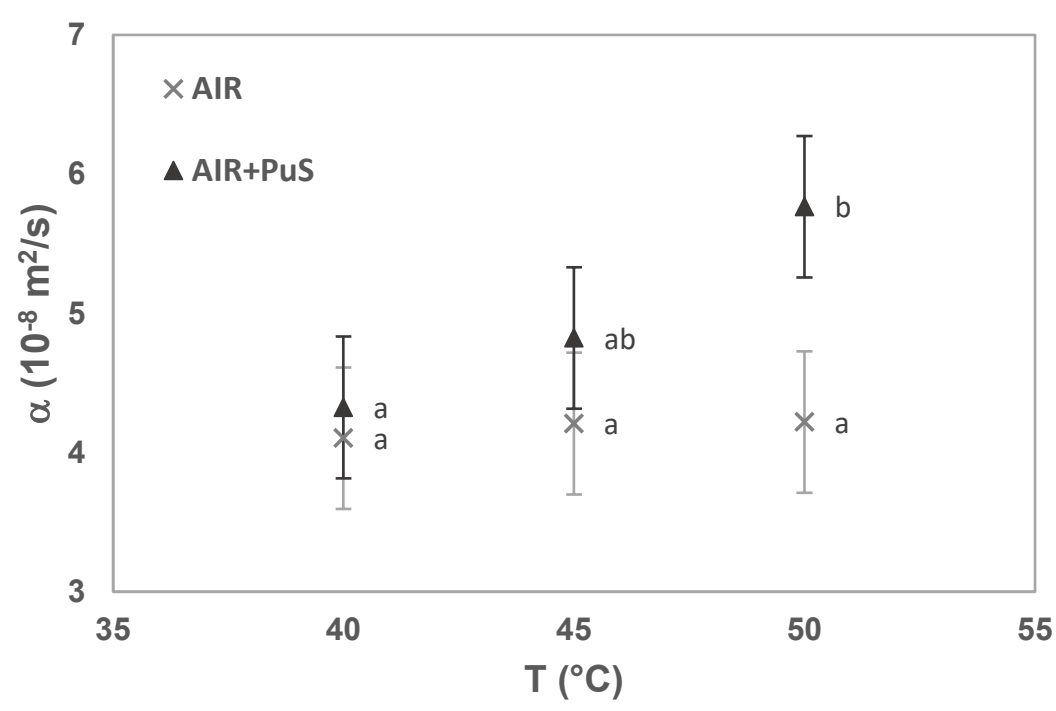

Figure 5. Apparent thermal diffusivity of dry-cured ham heated at different air temperatures (40, 45 , and $50^{\circ} \mathrm{C}$ ) (constant air velocity of $2 \mathrm{~m} / \mathrm{s}$ ) without (AIR) and with (AIR+PuS) the application of PuS. Letters show homogeneous groups stablished from LSD intervals (95\%). 
As regards the experiments carried out at different air velocities, the increase in air velocity provoked a significant $(\mathrm{p}=0.0011)$ increase in the apparent thermal diffusivity in the case of AIR experiments (Figure 6). Moreover, the lowest figures of the explained variance were found in experiments conducted at $1 \mathrm{~m} / \mathrm{s}$ (Table 1), which confirmed a better fit of the model at high air velocities due to the reduction in the external resistance to heat transfer, which made conduction phenomena predominant over convection. The trend in thermal diffusivity was towards an asymptotic value when the air velocity increased, reflecting an almost negligible influence of the convective flow for air velocities higher than $4 \mathrm{~m} / \mathrm{s}$. The explained variance did not reach values higher than $99 \%$ nor mean relative errors of under $10 \%$, probably because the influence of the plastic bag was not considered, and this acted as an additional external resistance to heat transfer regardless of the air flow rate used. As for AIR+PuS experiments, it was found that the greater increase in the apparent thermal diffusivity produced by air velocity appeared from 1 to $2 \mathrm{~m} / \mathrm{s}$ (42\%), whereas for the rest of the air velocities tested, it remained practically constant.

When AIR and AIR+PuS experiments were compared, it could be observed in Figure 6 that apparent thermal diffusivity was always higher for experiments with ultrasound application. Nevertheless, the higher the air velocity, the smaller the difference between AIR and AIR+PuS treatments. Thus, at $6 \mathrm{~m} / \mathrm{s}$, both treatments exhibited very similar apparent thermal diffusivity. As mentioned in section 3.1.2, this could be explained by the disruption of the ultrasonic field by the high air flow rates which made it difficult for the acoustic energy to reach the sample (Santacatalina et al., 2016) or because ultrasound was not capable of increasing heat conduction rates.

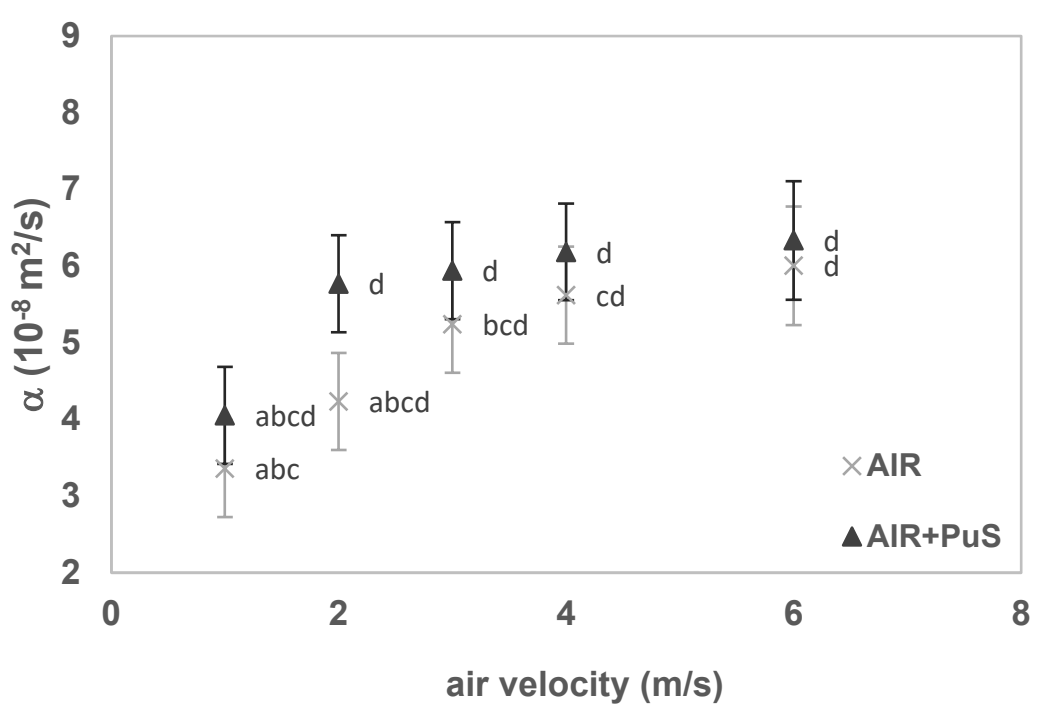

Figure 6. Apparent thermal diffusivity $(\alpha)$ of dry-cured ham heated at different air velocities $(1,2$, 3,4 and $6 \mathrm{~m} / \mathrm{s}$ ) (constant air temperature of $50{ }^{\circ} \mathrm{C}$ ) without (AIR) and with (AIR+PuS) the application of PuS. Letters show homogeneous groups stablished from LSD intervals (95\%). 


\subsection{Dry-cured ham texture}

In order to quantify the influence of the air temperature during the heating treatment on dry-cured ham texture, stress-relaxation tests were carried out. Thus, the increase in textural parameters was calculated as the difference between the treated samples and their controls. When comparing ultrasonically assisted heated samples with those conventionally heated, it was observed that the influence of PuS application on $\Delta$ hardness was not significant ( $p>0.05$, data not shown); therefore, to study the influence of temperature, the average for AIR and AIR $+\mathrm{PuS}$ experiments was considered. As can be observed in Figure 7, the heating induced an increase in the sample hardness since every hardness variation ( $\Delta$ hardness) estimated was positive, regardless of the heat treatment applied. Similarly, Morales et al. (2008) reported an increase in Biceps femoris muscle hardness after a thermal treatment at $30{ }^{\circ} \mathrm{C}$ for $168 \mathrm{~h}$. Moreover, air temperature significantly $(\mathrm{p}=0.0263)$ influenced $\Delta$ hardness, thus, similar values for this parameter were found at 40 and $45^{\circ} \mathrm{C}(6.3 \mathrm{~N}$ ), and a marked increase (up to $15.4 \mathrm{~N}$ ) was observed at $50{ }^{\circ} \mathrm{C}$ (Figure 7). This change could be linked to a modification in the protein matrix, since, during heating, the different meat proteins denature and structural changes, additional to what is provoked by salting during curing, occur (Tornberg, 2005). Cell membrane destruction (Rowe, 1989), the transversal and longitudinal shrinkage of meat fibers (Tornberg, 2005) and the aggregation of the globular heads of myosin (Morales et al., 2008) were some of the changes that could take place. Moreover, as the heating temperature rose, such changes became intensified.

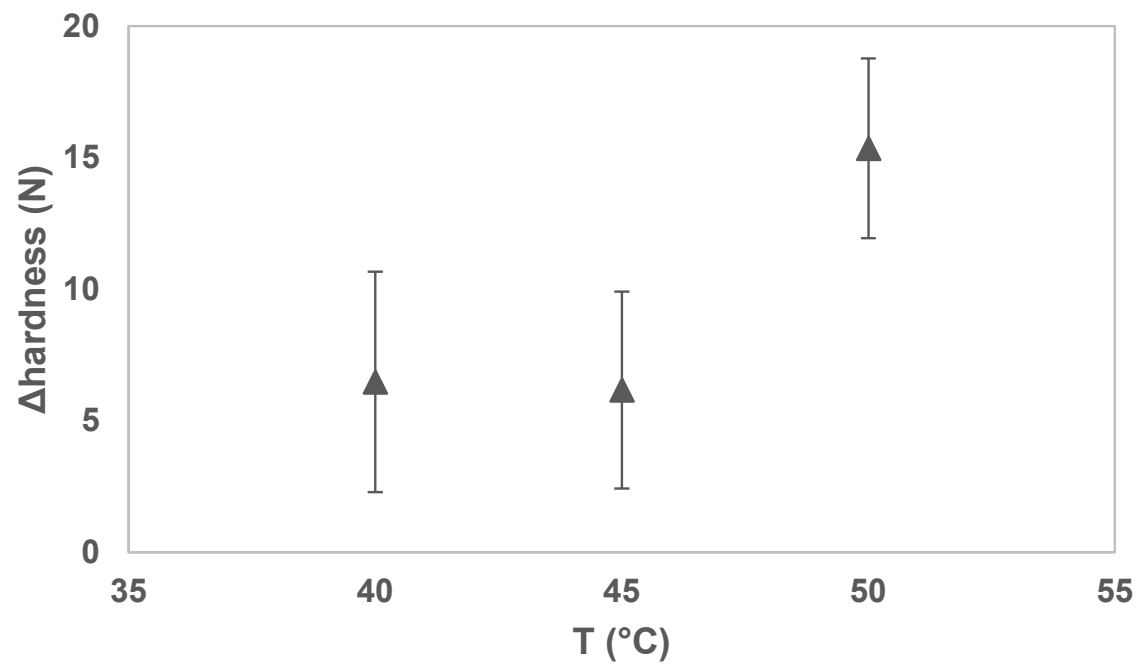

Figure 7. Hardness variation of dry-cured ham heated at 40,45 and $50{ }^{\circ} \mathrm{C}$ at $2 \mathrm{~m} / \mathrm{s}$. Average values for AIR and AIR+PuS experiments. Error bars show LSD intervals (95\%). 
Another textural parameter measured was the force decay (Y), which is inversely related to the material elasticity. Thus, the greater the elasticity of the material, the smaller the force decay during the relaxation period. A similar pattern was found for the variation between the treated and control samples in terms of the force decay at $2 \mathrm{~s}\left(\mathrm{Y}_{2}\right)$, and the final one $\left(\mathrm{Y}_{90}\right)$. The variation in both parameters was significantly $\left(\mathrm{p}=0.001\right.$ for $\mathrm{Y}_{2}$ and $\mathrm{p}=0.013$ for $\mathrm{Y}_{90}$ ) affected by temperature, but no effect of PuS application was found. Thus, both $\Delta \mathrm{Y}_{2}$ and $\Delta \mathrm{Y}_{90}$ were similar at 40 and $45{ }^{\circ} \mathrm{C}$ and were reduced at $50{ }^{\circ} \mathrm{C}$ (Figure 8). In the same way, Gou et al. (2008) found that after a 10-day ageing of dry-cured ham at $30{ }^{\circ} \mathrm{C}, \mathrm{Y}_{90}$ values decreased compared with the same time of ageing performed at $18{ }^{\circ} \mathrm{C}$. Besides that, the results obtained for force decay matched the one found for the variation in hardness, which confirmed that the heated dry-cured ham texture was dependent on the heating temperature. Thereby, the negative $\Delta \mathrm{Y}_{90}$ figures found at $50{ }^{\circ} \mathrm{C}$ corresponded to an increase in the ham elasticity. As the loss of elasticity is the main trait of the pastiness defect in dry-cured ham (García-Garrido et al., 2000), short thermal treatments such as those shown in this study could be useful for reducing textural defects prior to the commercialization of the product.

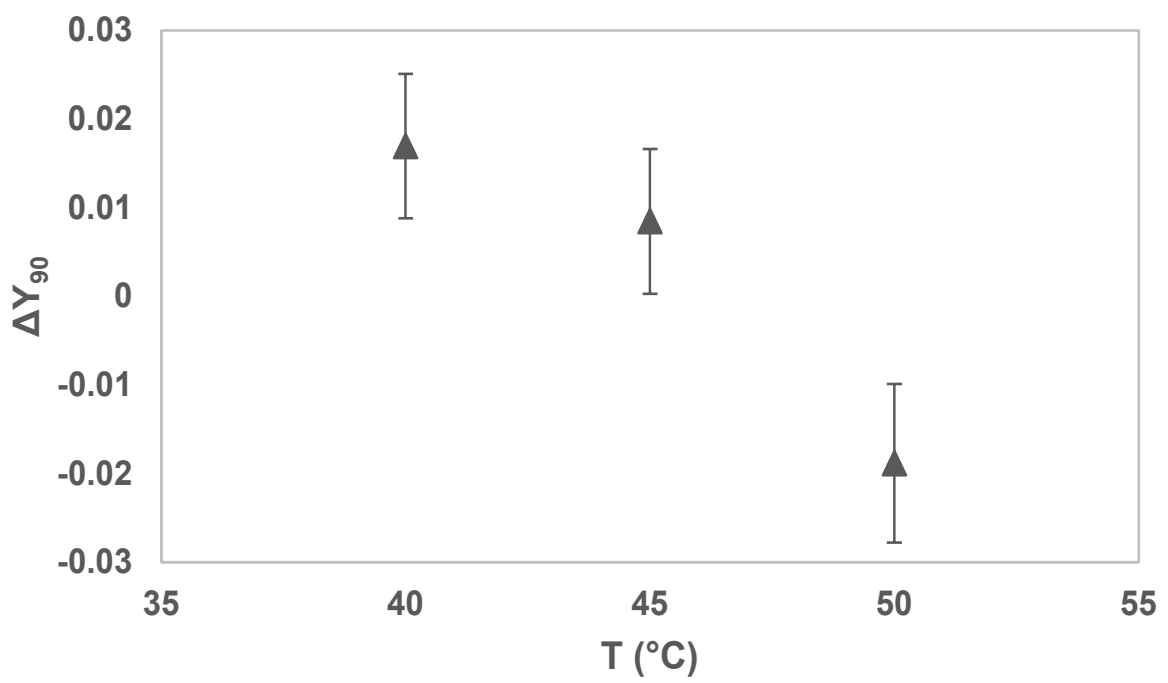

Figure 8. Force decay variation, $\triangle Y 99$, of dry-cured ham heated at 40,45 and $50{ }^{\circ} \mathrm{C}$ at $2 \mathrm{~m} / \mathrm{s}$. Average values for AIR and AIR+PuS experiments. Error bars show LSD intervals (95\%).

\section{Conclusions}

This study evidenced the influence of different operating variables (air velocity and temperature) on the heating kinetics of dry-cured ham during mild thermal treatments. In every air velocity-temperature condition tested, the application of airborne PuS increased the apparent thermal diffusivity. However, the magnitude of PuS effects depended on the air velocity and temperature; thus, ultrasound was more effective at high air temperatures and low air velocities. 
Besides, the heating process provoked an enhancement of the dry-cured ham texture, since it became harder. Therefore, airborne power ultrasound, which could be considered a feasible technique with which to shorten the heating time of dry-cured ham and improve its texture, is emerging as an alternative to hot water treatments.

\section{Acknowledgements}

The authors acknowledge financial support from the "Spanish Ministerio de Economía y Competitividad (MINECO), the Instituto Nacional de Investigación y Tecnología Agraria y Alimentaria (INIA)" in Spain, the European Regional Development Fund (ERDF 2014-2020) (Project RTA2013-00030-C03-02) and the PhD grant of M. Contreras from the Universitat Politècnica de València.

\section{References}

Akpinar, E. K., \& Toraman, S. (2016). Determination of drying kinetics and convective heat transfer coefficients of ginger slices. Heat and Mass Transfer/Waerme- Und Stoffuebertragung, 52, 2271-2281.

Alarcon-Rojo, A. D., Janacua, H., Rodriguez, J. C., Paniwnyk, L., \& Mason, T. J. (2015). Power ultrasound in meat processing. Meat Science, 107, 86-93.

Ashokkumar, M. (2011). The characterization of acoustic cavitation bubbles - An overview. Ultrasonics Sonochemistry, 18, 864-872.

Ayadi, M. A., Makni, I., \& Attia, H. (2009). Thermal diffusivities and influence of cooking time on textural, microbiological and sensory characteristics of turkey meat prepared products. Food and Bioproducts Processing, 87, 327-333.

Bantle, M., \& Hanssler, J. (2013). Ultrasonic convective drying kinetics of clipfish during the initial drying period. Drying Technology, 31, 1307-1316.

Benali, M., \& Kudra, T. (2010). Process intensification for drying and dewatering. Drying Technology, 28, 1127-1135.

Chandrapala, J., Oliver, C., Kentish, S., \& Ashokkumar, M. (2012). Ultrasonics in food processing. Ultrasonics Sonochemistry, 19, 975-983.

Chemat, F., Zill-E-Huma, \& Khan, M. K. (2011). Applications of ultrasound in food technology: processing, preservation and extraction. Ultrasonics Sonochemistry, 18, 813- 
835.

García-Garrido, J. A, Quiles-Zafra, R., Tapiador, J., \& Luque de Castro, M. D. (2000). Activity of cathepsin B, D, H and L in Spanish dry-cured ham of normal and defective texture. Meat Science, 56, 1-6.

Garcia-Perez, J. V., Cárcel, J. A., de la Fuente-Blanco, S., \& Riera-Franco de Sarabia, E. (2006a). Ultrasonic drying of foodstuff in a fluidized bed: Parametric study. Ultrasonics, $44,539-543$.

Garcia-Perez, J. V., Cárcel, J. A., Simal, S., García-Alvarado, M. A., \& Mulet, A. (2013). Ultrasonic intensification of grape stalk convective drying: kinetic and energy efficiency. Drying Technology: An International Journal, 318, 942-950.

Garcia-Perez, J. V., Rosselló, C., Cárcel, J. A., De la Fuente, S., \& Mulet, A. (2006b). Effect of air temperature on convective drying assisted by high power ultrasound. Defect and Diffusion Forum, 258-260, 563-574.

García-Rey, R. M., García-Garrido, J. A., Quiles-Zafra, R., Tapiador, J., \& Luque de Castro, M. D. (2004). Relationship between $\mathrm{pH}$ before salting and dry-cured ham quality. Meat Science, 67, 625-632.

Ghisalberti, L., \& Kondjoyan, A. (1999). Convective heat transfer coefficients between air flow and a short cylinder. Effect of air velocity and turbulence. Effect of body shape, dimensions and position in the flow. Journal of Food Engineering, 42, 33-44.

Gou, P., Morales, R., Serra, X., Guàrdia, M. D., \& Arnau, J. (2008). Effect of a 10-day ageing at $30{ }^{\circ} \mathrm{C}$ on the texture of dry-cured hams processed at temperatures up to $18{ }^{\circ} \mathrm{C}$ in relation to raw meat $\mathrm{pH}$ and salting time. Meat Science, 80, 1333-1339.

Hernández, J. A., Heyd, B., \& Trystram, G. (2008). Prediction of brightness and surface area kinetics during coffee roasting. Journal of Food Engineering, 89, 156-163.

Hii, C. L., Menon, A. S., Chiang, C. L., \& Sharif, S. (2016). Kinetics of hot air roasting of cocoa nibs and product quality. Journal of Food Process Engineering, 00, 1-6.

Holman, J. P. (1986). Heat transfer. McGraw-Hill.

Legay, M., Gondrexon, N., Le Person, S., Boldo, P., \& Bontemps, A. (2011). Enhancement of heat transfer by ultrasound: Review and recent advances. International Journal of Chemical Engineering, 2011, 1-17.

Mason, T. J., Paniwnyk, L., \& Lorimer, J. P. (1996). The uses of ultrasound in food technology. Ultrasonics Sonochemistry, 3, S253-S260.

Morales, R., Arnau, J., Serra, X., Guerrero, L., \& Gou, P. (2008). Texture changes in dry-cured ham pieces by mild thermal treatments at the end of the drying process. Meat Science, 80 , 
231-238.

Morales, R., Guerrero, L., Serra, X., \& Gou, P. (2007). Instrumental evaluation of defective texture in dry-cured hams. Meat Science, 76, 536-542.

Povey, M. J. W., \& Mason, T. J. (1998). Ultrasound in food processing (first edit). Springer.

Riera, E., Vicente García-Pérez, J., Cárcel, J. A., Acosta, V. M., \& Gallego-Juárez, J. A. (2011). Computational study of ultrasound-assisted drying of food materials. In Innovative Food Processing Technologies: Advances in Multiphysics Simulation. John Wiley \& Sons.

Rinaldi, M., Chiavaro, E., \& Massini, R. (2010). Apparent thermal diffusivity estimation for the heat transfer modelling of pork loin under air/steam cooking treatments. International Journal of Food Science and Technology, 45, 1909-1917.

Rowe, R. W. D. (1989). Electron microscopy of bovine muscle: II-The effects of heat denaturation on post rigor sarcolemma and endomysium. Meat Science, 26, 281-294.

Santacatalina, J. V, Soriano, J. R., \& Cárcel, J. A. (2016). Influence of air velocity on low temperature drying of eggplant assisted by power ultrasound. Food and Bioproducts Processing, 100, 2-4.

Tornberg, E. (2005). Effects of heat on meat proteins - Implications on structure and quality of meat products. Meat Science, 70, 493-508.

Ventanas, J., \& Andrés, A. I. (2001). Tecnología del jamón Ibérico: de los sistemas tradicionales a la explotación racional del sabor y el aroma. Mundi-Prensa.

Virgili, R., Parolari, G., Schivazappa, C., Bordini, C. S., \& Borri, M. (1995). Sensory and texture quality of dry-cured ham as affected by endogenous cathepsin B activity and muscle composition. Journal of Food Science, 60, 1183-1186.

Yao, Y. (2016). Enhancement of mass transfer by ultrasound: Application to adsorbent regeneration and food drying/dehydration. Ultrasonics Sonochemistry, 31, 512-531.

Yao, Y., Wang, W., \& Yang, K. (2015). Mechanism study on the enhancement of silica gel regeneration by power ultrasound with field synergy principle and mass diffusion theory. International Journal of Heat and Mass Transfer, 90, 769-780.

Zhang, W., Yao, Y., \& Wang, R. (2010). Influence of ultrasonic frequency on the regeneration of silica gel by applying high-intensity ultrasound. Applied Thermal Engineering, 30, 2080-2087. 


LWT - Food Science and Technology, 2020, 126, 109283.

\title{
Correction of defective textures in packaged dry- cured pork ham by applying conventional and ultrasonically-assisted mild thermal treatments
}

\author{
Marina Contreras ${ }^{1}$, Jose Benedito ${ }^{1}$, Amparo Quiles ${ }^{1}$, Jose Manuel \\ Lorenzo $^{2}$, Elena Fulladosa ${ }^{3}$, Jose Vicente Garcia-Perez ${ }^{1}$
}

${ }^{1}$ Grupo de Análisis y Simulación de Procesos Agroalimentarios (ASPA). Departamento de Tecnología de Alimentos. Universitat Politècnica de València. Camí de Vera s/n, Valencia (46022), Spain.

${ }^{2}$ Centro Tecnológico de la Carne (CTC). Parque Tecnolóxico de Galicia. Avenida de Galicia 4, San Cibrao das Viñas (32900), Ourense, Spain.

${ }^{3}$ Institut de Recerca i Tecnologia Agroalimentàries (IRTA), Finca Camps i Armet, Monells (17121), Girona, Spain. 



\title{
Correction of defective textures in packaged dry-cured pork ham by applying conventional and ultrasonically-assisted mild thermal treatments
}

\begin{abstract}
Pastiness is a textural defect characterized by an excessive softness and loss of elasticity which lacks corrective actions at industrial level. The objective of this study was to evaluate the textural and microstructural changes of dry-cured pork ham, with different pastiness levels, subjected to conventional and ultrasonically-assisted corrective mild thermal treatments. Pastiness was assessed by an expert sensory panel and hams were classified into three categories: high (HP), medium (MP) and no (NP) pastiness. Ham samples ( $n=108)$ were heated (40 and 50 ${ }^{\circ} \mathrm{C}$ ) with power ultrasound (PuS) and without (CV) PuS application. After heating, all of the textural parameters assessed were improved. Hardness increased by $102 \%$ and adhesiveness decreased by $55 \%$ and the ham became less viscoelastic. The largest modifications were found in the samples heated at $50{ }^{\circ} \mathrm{C}$ and no differences were found between $\mathrm{CV}$ and PuS treatments. The microstructure of pasty samples revealed that the treatment produced a shrinkage of the myofibrils, which could explain the increase in hardness and the improvement in texture of defective ham.
\end{abstract}

Keywords: dry-cured ham; texture; microstructure; heating; ultrasound. 


\section{Introduction}

During dry-cured ham processing, there are many factors such as temperature, $\mathrm{pH}$, muscle type, water content and availability or salt content, among others, which affect the development of the product's characteristic texture (Bermúdez et al., 2014). In this regard, low or high pH in the raw ham, low salt contents, high temperatures and a short resting period may induce defective textures (Arnau et al., 1998; Garcia-Garrido et al., 1999). The most relevant textural defects are softness and pastiness, which influence negatively the consumer acceptance of dry-cured ham and also promote technological problems, such as the adhesiveness. Recently, Contreras et al. (2020) characterized the defect of pastiness using conventional techniques, such as instrumental texture, chemical and microstructural analysis, and also non-destructive ultrasonic testing. Diverse studies have reported that at the end of the ham processing the extension of the aging stage and a slight temperature increase could reduce the intensity of these textural defects. In this sense, Cilla et al. (2005) stated that extending ham maturation time to 20 months $\left(18{ }^{\circ} \mathrm{C}, 75 \% \mathrm{RH}\right)$ increased hardness and decreased adhesiveness. Similarly, Gou et al. (2008) confirmed that including a final aging stage at $30{ }^{\circ} \mathrm{C}$ and low relative humidity (40-45\%) during the last 10 days of ham manufacturing could improve its texture. While, Morales et al. (2008) tested in sections of drycured ham $\left(4 \mathrm{~cm}\right.$ thick) a slight temperature increase $\left(30^{\circ} \mathrm{C}\right)$ during a short storage (30 days) that involved a decrease in softness, pastiness and adhesiveness in BF muscle. The main drawback of these approaches was the long time employed for texture correction. Additionally, high hydrostatic pressure (HHP) treatments were also tested to improve the ham texture. In this sense, Garcia-Gil et al. (2014) found that the HHP treated ham (500 MPa) was harder and presented more elastic behavior. Likewise, Coll-Brasas et al. (2019) identified an increase in hardness and a decrease in pastiness in dry-cured hams with different levels of pastiness after HHP treatment (600 MPa), which was more intense as the treatment temperature rose. In this regard, the use of HHP at the end of the processing of dry-cured ham could help to improve its texture in addition to eliminating pathogenic microorganisms and extending its shelf-life. However, the implementation of HHP at industrial level is constrained by its high cost compared to other more affordable alternatives.

The feasibility of using mild temperatures, from 40 to $50{ }^{\circ} \mathrm{C}$, and short treatment times has recently been explored in order to bring about texture modifications in dry-cured ham in both air (Contreras et al., 2018b) and water media (Contreras et al., 2018a). The mild thermal treatment induced an increase in the sample hardness; thus, the higher the treatment temperature, the harder the ham. Contreras et al. (2018a and 2018b) used a small number of samples of commercial drycured hams without textural defects, since the main aim of both studies was to test the feasibility of power ultrasound $(\mathrm{PuS})$ to accelerate the heating process (Lacivita et al., 2018; Sun et al., 2019). In addition, samples were heated only until they reached a target temperature defined as 5 ${ }^{\circ} \mathrm{C}$ below the temperature of the heating medium. Thus, very short treatment times were applied, 
ranging from 16 to $24 \mathrm{~min}$, depending on the sample size, air-water medium and temperature used. In this way, it should be expected that an additional holding phase at the heating medium temperature could promote a greater modification of the texture than that found in the aforementioned studies. Other previous studies addressing corrective actions for textural enhancement based on a slight temperature increase have also tested a limited number of samples (Garcia-Gil et al., 2014; Morales et al., 2008). In this sense, a more exhaustive experimentation, using a large number of samples with a wide range of pastiness values is necessary to evaluate the performance of the corrective action depending on the initial product properties, which constitutes an approach never addressed before to our knowledge. Therefore, the aim of this study was to assess the textural and microstructural modifications undergone by dry-cured ham with different levels of pastiness subjected to mild thermal treatments using conventional and PuS heating systems.

\section{Materials and methods}

\subsection{Raw material}

Dry-cured hams $(n=108)$ from Large White and Landrace animal breed crosses were used. Dry-cured ham manufacturing was modified as described in detail by Contreras et al. (2020) to induce pastiness over a wide intensity range. At the end of the processing, the cushion part of dry-cured hams was sliced into different formats. Thin slices (thickness $1.5 \mathrm{~mm}$ ) were used for sensory pastiness evaluation and microstructural analyses, and packages of 4 slices were prepared for the adhesiveness test. Thicker slices (thickness $20 \mathrm{~mm}$ ), meanwhile, were used for hardness and elasticity tests and ultrasonic analysis. Afterwards, all the samples were vacuum-packed in individual plastic bags of polyamide/polyethylene (oxygen permeability of $50 \mathrm{~cm}^{3} / \mathrm{m}^{2} / 24 \mathrm{~h}$ at 23 ${ }^{\circ} \mathrm{C}$ and water permeability of $2.6 \mathrm{~g} / \mathrm{m}^{2} / 24 \mathrm{~h}$ at $23{ }^{\circ} \mathrm{C}$ and $85 \% \mathrm{RH}$, Sacoliva ${ }^{\circledR}$ S.L., Spain). From each ham piece, two thick slices $(20 \mathrm{~mm})$ and 2 packages of thin slices $(1.5 \mathrm{~mm})$ were used. Thereby, the destructive instrumental textural tests could be performed in identical samples before (control) and after the thermal treatment. Finally, packaged samples were stored in a chamber at $4 \pm 2{ }^{\circ} \mathrm{C}$ until the experiments were performed.

\subsection{Sensory texture analysis}

A three-member expert panel, trained following the American Society for Testing and Materials standards (ASTM STP 758, 1981), performed the sensory texture analysis on dry-cured ham slices (thickness $1.5 \mathrm{~mm}$ ). The textural attribute evaluated in BF muscle was pastiness, which can be defined as a feeling similar to the mouth-coating sensation produced by flour-water paste during the mastication process. Dry-cured ham slices presented different levels of pastiness. The levels of ham pastiness were ranked from 0 (absence) to 6 (maximum intensity). The pastiness 
level of the samples was set as the average score of the three experts' scores. Thus, dry-cured hams were classified according to the textural defect into samples with no pastiness (pastiness $<1$ ), medium pastiness (pastiness between 1-2.5) and high pastiness (pastiness>2.5). For every level of pastiness, 36 samples were selected.

\subsection{Mild thermal treatments}

Mild thermal treatments were carried out by placing packaged samples into a temperature controlled water bath following the same methodology already described by Contreras et al. (2018a). Two different temperatures were tested $\left(40\right.$ and $\left.50^{\circ} \mathrm{C}\right)$ and the treatment time was $5 \mathrm{~h}$ in both cases. In conventional thermal treatments $(\mathrm{CV})$, a mechanical stirrer was used to improve the liquid turbulence, while ultrasonically assisted treatments $(\mathrm{PuS})$ were carried out in an ultrasonic bath $(600 \mathrm{~W}, 20 \mathrm{kHz})$ supplied with a custom temperature control (Contreras et al., 2018a). Ultrasound was only applied during the heating phase, which represents the time needed to reach a temperature of $5{ }^{\circ} \mathrm{C}$ below the temperature of the heating medium in the center of the slice. The duration of the heating phase was determined by the mathematical model proposed by Contreras et al. (2018a) for dry-cured ham slices. Once the heating phase finished, the ultrasound generator was switched off and samples were held at the pre-set temperature until completing a total treatment time of $5 \mathrm{~h}$. During this holding phase, the same mechanical stirrer as in $\mathrm{CV}$ experiments was used.

Every experimental condition $\left(40-50{ }^{\circ} \mathrm{C}, \mathrm{CV}-\mathrm{PuS}\right)$ was tested in dry-cured ham with different pastiness levels (high, medium and no pastiness). For each pastiness level, 9 slices (20 $\mathrm{mm}$ thick) and 9 packages (containing 4 slices, $1.5 \mathrm{~mm}$ thick per package) were thermal treated (CV and PuS assisted) at 40 and $50{ }^{\circ} \mathrm{C}$, which makes 108 treatments for each sample thickness (slices $20 \mathrm{~mm}$ thick and sliced packages).

A preliminary test was conducted in order to choose the appropriate duration of the heat treatments. The objective of this test was to obtain the largest textural modifications without inducing a cooked flavor or appearance in the dry-cured ham. For that purpose, 18 cylinders (diameter $2.52 \pm 0.11 \mathrm{~cm}$ and height $1.9 \pm 0.14 \mathrm{~cm}$ ) from commercial dry-cured hams were heated with $(\mathrm{PuS})$ and without $(\mathrm{CV})$ ultrasound application at $50^{\circ} \mathrm{C}$ modifying the total treatment time: 1, 3 and $5 \mathrm{~h}$. Each experiment was replicated at least three times. Finally, the initial hardness of the samples $\left(\mathrm{F}_{\mathrm{i}}\right)$, which was used as control, was compared to the final hardness $\left(\mathrm{F}_{\mathrm{f}}\right)$ after the treatment (Figure 1). The experimental results from the preliminary test showed that the hardness ratio $\left(\mathrm{F}_{\mathrm{f}} / \mathrm{F}_{\mathrm{i}}\right)$ in $\mathrm{CV}$ and PuS treatments ranged from $2.3 \pm 0.8$ to $3.3 \pm 0.8$ when heating for 1 and 5 $\mathrm{h}$, respectively (Figure 1). A hardness ratio above one indicated that softness, which is one of the main consequences of pastiness, was reduced. Although there was a considerable dispersion in the hardness ratio, probably due to the heterogeneity of the commercial dry-cured ham used, it 
could be observed that the hardness ratio increased as the treatment time lengthened in the case of both $\mathrm{CV}$ and PuS experiments. Longer treatment times $(6,7$ and $10 \mathrm{~h})$ were also evaluated in preliminary tests but were discarded since they caused the appearance of cooking flavors. For that reason, the treatment time chosen to analyze the improvement in the textural properties of drycured ham brought about by mild thermal treatments was $5 \mathrm{~h}$.

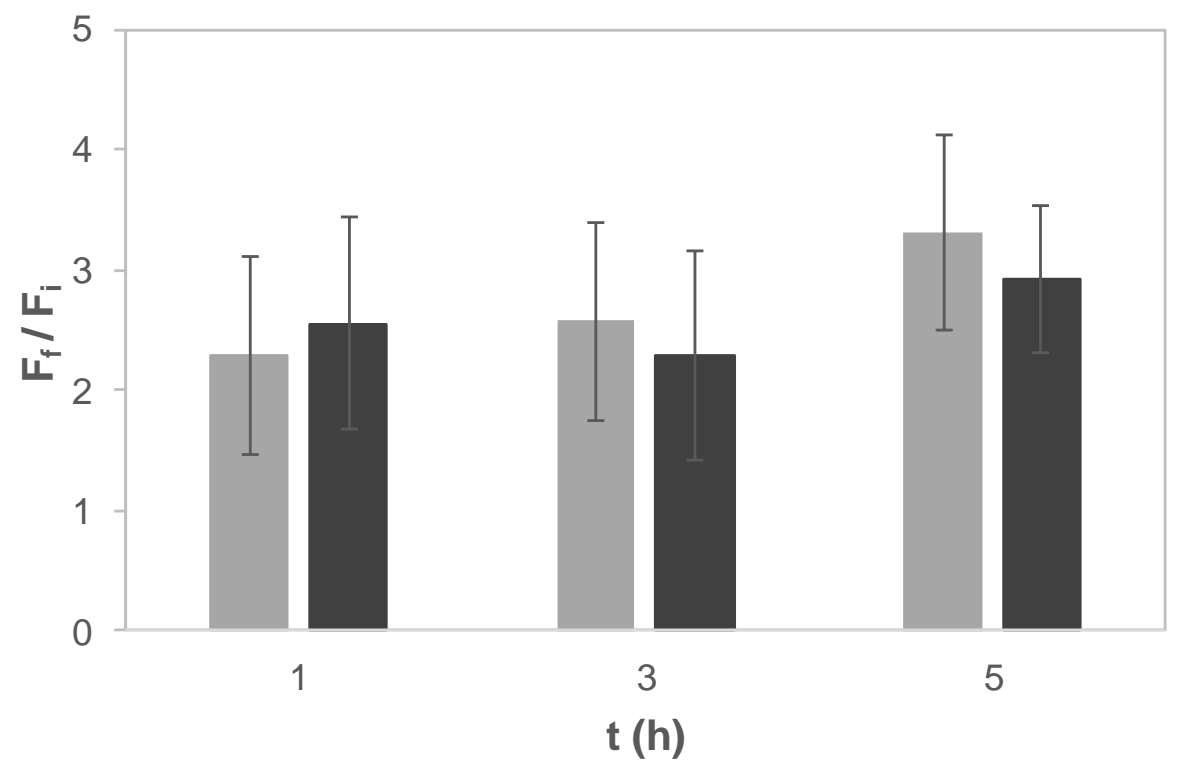

Figure 1. Influence of treatment time at $50^{\circ} \mathrm{C}$ on the hardness ratio $\left(F_{f} / F_{i}\right)$ of dry-cured ham. $F_{i}$ and $F_{f}$ are the initial and final sample hardness values, respectively. Average values \pm standard deviation values are plotted. Conventional $(\square \mathrm{CV})$ and ultrasonically-assisted ( $\mathrm{PuS})$ mild thermal treatments are shown.

\subsection{Instrumental texture analysis}

In order to evaluate the changes caused by the heat treatment in dry-cured ham texture, different properties (hardness, elasticity and adhesiveness) were measured before $\left(\mathrm{X}_{\mathrm{i}}\right)$ and after $\left(X_{f}\right)$ heating. The ratio between the final and the initial textural property $\left(X_{f} / X_{i}\right)$ was computed in order to standardize and make reliable comparisons between treatments with samples of different initial textural properties.

\subsubsection{Hardness and elasticity}

Hardness and elasticity were measured using a texturometer (TA-XT2, SMS, Godalming, UK) provided with a load cell of $50 \mathrm{~kg}$. From the slices of $20 \pm 4 \mathrm{~mm}, 5$ parallelepipeds of BF muscle were carved (20 mm length x $20 \mathrm{~mm}$ width $\mathrm{x} 15 \mathrm{~mm}$ height). Stress-relaxation tests were carried out at a constant temperature $\left(4 \pm 1^{\circ} \mathrm{C}\right)$ using a flat $75 \mathrm{~mm}$ diameter aluminum probe (SMS $\mathrm{P} / 75$ ). The samples were compressed to $25 \%$ of their original height perpendicular to the fiber 
bundle direction at a crosshead speed of $1 \mathrm{~mm} / \mathrm{s}$ and, afterwards, the probe was held for $90 \mathrm{~s}$ to monitor relaxation. The experimental data were recorded and processed with Exponent Lite 6.1.4.0 software (SMS, Godalming, UK). Thus, hardness $(F)$ was computed from the force versus time profiles as the maximum force achieved during compression, while elastic behavior was indirectly assessed by computing the force decay, $Y_{t}$, logged during relaxation since its increase reflects a more viscoelastic behavior (Eq. 1):

$$
Y_{t}=\frac{F_{\max }-F_{t}}{F_{\max }}
$$

where $F_{\max }$ is the maximum force during compression $(\mathrm{N})$ and $F_{t}$ is the force recorded after $t$ seconds of relaxation. $Y_{t}$ was calculated after $2 \mathrm{~s}$ of the relaxation period $\left(Y_{2}\right)$ and at the end of the stress-relaxation test $\left(90 \mathrm{~s}, Y_{90}\right)$.

\subsubsection{Adhesiveness}

The adhesiveness was analyzed using a texturometer (TA-XT Plus, SMS, Godalming, UK) provided with a load cell of $0.5 \mathrm{~kg}$ following the methodology proposed by López-Pedrouso et al. (2018). From a dry-cured ham package containing 4 slices ( $1.5 \mathrm{~mm}$ thick), these were separated one by one in order to measure adhesiveness. The probe was placed at one end of the slice and displaced horizontally $(100 \mathrm{~mm})$ at a crosshead speed of $5 \mathrm{~mm} / \mathrm{s}$, detaching both slices. The adhesiveness measurements were carried out at a constant temperature $\left(20 \pm 2{ }^{\circ} \mathrm{C}\right)$. The experimental data were recorded and processed with Exponent Lite 6.1.4.0 software (SMS, Godalming, UK). Thus, adhesiveness was computed from the force versus time profiles as the maximum force achieved during the separation test with a single-cycle. For each package, three measurements were taken.

\subsection{Microstructure}

The dry-cured ham microstructure was analyzed using two microscopic techniques: light microscopy (LM) and transmission electron microscopy (TEM). Between 4-5 different samples per level of pastiness were randomly chosen and analyzed. Thus, from slices $1.5 \mathrm{~mm}$ thick, small sections $(5 \times 3 \mathrm{~mm})$ from BF muscle were cut with a disposable blade. In order to include the sections, samples were fixed with a $25 \mathrm{~g} / \mathrm{L}$ glutaraldehyde solution $(0.025 \mathrm{M}$ phosphate buffer, $\mathrm{pH}$ 6.8 , at $\left.4{ }^{\circ} \mathrm{C}, 24 \mathrm{~h}\right)$, postfixed with a $20 \mathrm{~g} / \mathrm{L} \mathrm{OsO}_{4}$ solution $(1.5 \mathrm{~h})$, dehydrated using a graded acetone series (300, 500, 700 and $1000 \mathrm{~g} / \mathrm{kg}$ ), contrasted in $40 \mathrm{~g} / \mathrm{L}$ uranyl acetate dissolved in acetone and embedded in epoxy resin (Durcupan, Sigma-Aldrich, St. Louis, MO, USA). The samples were cut using a Reichert Jung ultramicrotome (Leica Mycrosystems, Wetzlar, Germany). Thin sections $(1.5 \mu \mathrm{m})$ were stained with $2 \mathrm{~g} / \mathrm{L}$ toluidine blue and examined in a Nikon 
Eclipse E800 light microscope (Nikon, Tokyo, Japan). Ultrathin sections $(0.5 \mu \mathrm{m})$ were stained with $40 \mathrm{~g} / \mathrm{L}$ lead citrate and observed in a Philips EM400 (Philips, Eindhoven, Holland) transmission electronic microscope at $80 \mathrm{kV}$. Dry-cured ham samples with high, medium and no pastiness were observed before and after PuS heat treatment at $50^{\circ} \mathrm{C}$.

\subsection{Statistical analysis}

One-way analysis of variance (ANOVA) $(\mathrm{p}<0.05)$ was performed to assess the influence of the type of thermal treatment (CV-PuS) on the textural parameters of treated samples. Likewise, multifactor ANOVA ( $\mathrm{p}<0.05)$ was performed in order to evaluate the influence of the temperature $\left(40-50{ }^{\circ} \mathrm{C}\right)$ and the level of pastiness intensity (high, medium and no pastiness) and also whether their interactions had a significant influence on every measured textural parameter. ANOVAs and least significant difference (LSD) intervals were estimated using the statistical package Statgraphics Centurion XVI (Statpoint Technologies Inc., Warrenton, VA, USA) considering a significance level of $95 \%$.

\section{Results and discussion}

\subsection{Effect of mild thermal treatment on dry-cured ham texture}

\subsubsection{Influence of $\mathrm{PuS}$ application}

The present study is exploring whether the previously reported kinetic improvement of PuS during the heating phase (Contreras et al., 2018a) was coupled to an additional textural modification by testing dry-cured hams over a wide range of pastiness intensities. Table 1 shows the ratios of the different textural parameters analyzed (hardness, elasticity and adhesiveness) before and after heat treatment for both $\mathrm{CV}$ and PuS experiments. There was not any statistical difference $(p>0.05)$ for the analyzed parameters between CV and PuS. The negligible effect of $\mathrm{PuS}$ was already anticipated by the preliminary test carried out to determine the duration of the thermal treatment (Figure 1). This fact could be explained by considering that the ultrasound application was restricted only to the heating phase, which only represents a short time (7.5-11 min) compared to the duration of the whole treatment $(5 \mathrm{~h})$. Therefore, although the use of PuS during mild thermal treatments could be used to speed-up the heating phase, allowing the desired temperature in the ham slice to be reached faster (Contreras et al., 2018a), it does not induce additional textural changes to the one caused by the heating itself. Previous studies reported similar results; thus, Lyng et al. (1997 \& 1998) confirmed that the texture of sonicated beef was not changed by ultrasonic treatment. Notwithstanding this, different studies have also demonstrated the feasibility of using PuS for improving meat tenderness in different products, such as poultry (Xiong et al., 2012) or beef (Kang et al., 2017). This contrary effect could be 
related to the energy applied, since long, high power treatments may cause a reduction in hardness. Future research should be conducted in order to elucidate whether extending ultrasonic application to the holding phase during the thermal treatment could bring about some textural modifications in dry-cured ham.

Table 1. Ratios of hardness (F), relaxation capacity parameters ( $\left.\mathbf{Y}_{2}, \mathbf{Y}_{90}\right)$ and adhesiveness (A) of drycured ham heated at 40 and $50^{\circ} \mathrm{C}$ without $(\mathrm{CV})$ and with $(\mathrm{PuS})$ ultrasound application of samples with high (HP), medium (MP) and no pastiness (NP). Ratios refer to the relationship between the final (f) and the initial (i) textural properties.

\begin{tabular}{|c|c|c|c|c|c|c|}
\hline & \multicolumn{3}{|c|}{ CV } & \multicolumn{3}{|c|}{ PuS } \\
\hline & HP & MP & NP & HP & MP & $\mathbf{N P}$ \\
\hline$F_{f} / F_{i, 40}{ }^{\circ} \mathrm{C}$ & $1.10 \pm 0.52^{\mathrm{a}}$ & $1.28 \pm 0.74^{\mathrm{a}}$ & $1.44 \pm 0.42^{\mathrm{a}}$ & $0.87 \pm 0.27^{\mathrm{x}}$ & $1.34 \pm 0.57^{x}$ & $1.26 \pm 0.36^{\mathrm{x}}$ \\
\hline $\mathbf{F}_{\mathrm{f}} / \mathbf{F}_{\mathrm{i}, 50^{\circ} \mathrm{C}}$ & $2.61 \pm 0.64^{\mathrm{b}}$ & $3.03 \pm 0.83^{b}$ & $2.64 \pm 0.51^{\mathrm{b}}$ & $2.78 \pm 0.6^{y}$ & $3.24 \pm 0.65^{\mathrm{y}}$ & $2.54 \pm 0.45^{\mathrm{y}}$ \\
\hline $\mathbf{Y}_{2, \mathrm{f}} / \mathbf{Y}_{2, \mathrm{i}}, 40^{\circ} \mathrm{C}$ & $0.97 \pm 0.04^{\mathrm{c}}$ & $0.95 \pm 0.06^{\mathrm{c}}$ & $0.93 \pm 0.06^{\mathrm{bc}}$ & $0.99 \pm 0.02^{z}$ & $0.93 \pm 0.07^{\mathrm{yz}}$ & $0.97 \pm 0.12^{\mathrm{yz}}$ \\
\hline $\mathbf{Y}_{2, \mathrm{f}} / \mathbf{Y}_{2, \mathbf{i}}, 50^{\circ} \mathrm{C}$ & $0.87 \pm 0.04^{b}$ & $0.81 \pm 0.05^{\mathrm{a}}$ & $0.80 \pm 0.04^{\mathrm{a}}$ & $0.89 \pm 0.06^{y}$ & $0.79 \pm 0.09^{x}$ & $0.78 \pm 0.05^{x}$ \\
\hline$Y_{90, \mathrm{f}} / Y_{90, \mathrm{i}}, 40^{\circ} \mathrm{C}$ & $0.98 \pm 0.04^{\mathrm{c}}$ & $0.96 \pm 0.04^{b c}$ & $0.92 \pm 0.05^{\mathrm{b}}$ & $0.98 \pm 0.02^{z}$ & $0.95 \pm 0.04^{\mathrm{yz}}$ & $0.94 \pm 0.04^{\mathrm{yz}}$ \\
\hline $\mathbf{Y}_{90, \mathrm{f}} / \mathbf{Y}_{90, \mathrm{i}},{ }_{50}{ }^{\circ} \mathrm{C}$ & $0.90 \pm 0.03^{b}$ & $0.84 \pm 0.05^{\mathrm{a}}$ & $0.82 \pm 0.02^{\mathrm{a}}$ & $0.92 \pm 0.03^{y}$ & $0.84 \pm 0.06^{\mathrm{x}}$ & $0.81 \pm 0.03^{x}$ \\
\hline $\mathbf{A}_{\mathrm{f}} / \mathbf{A}_{\mathrm{i}, 40^{\circ} \mathrm{C}}$ & $0.49 \pm 0.16^{\mathrm{b}}$ & $0.40 \pm 0.12^{\mathrm{ab}}$ & $0.47 \pm 0.18^{b}$ & $0.54 \pm 0.13^{x y}$ & $0.44 \pm 0.14^{x y}$ & $0.44 \pm 0.15^{x y}$ \\
\hline $\mathbf{A}_{\mathbf{f}} / \mathbf{A}_{\mathbf{i}}, \mathbf{5 0}^{\circ} \mathrm{C}$ & $0.51 \pm 0.12^{b}$ & $0.41 \pm 0.13^{\mathrm{ab}}$ & $0.30 \pm 0.14^{\mathrm{a}}$ & $0.49 \pm 0.19^{x y}$ & $0.47 \pm 0.19^{x y}$ & $0.39 \pm 0.14^{x}$ \\
\hline
\end{tabular}

Average values \pm standard deviation are shown. Superscript letters $(\mathrm{a}, \mathrm{b}, \mathrm{c})$ and $(\mathrm{x}, \mathrm{y}, \mathrm{z})$ show homogeneous groups in both $\mathrm{CV}$ and PuS experiments, respectively, established from LSD (Least Significance Difference) intervals $(p<0.05)$ considering the influence of temperature and pastiness level on each textural parameter ratio.

\subsubsection{Influence of the thermal treatment on hardness}

The computed hardness ratio $\left(\mathrm{F}_{\mathrm{f}} / \mathrm{F}_{\mathrm{i}}\right)$ constitutes a simple way of assessing if hardness increased $\left(\mathrm{F}_{\mathrm{f}} / \mathrm{F}_{\mathrm{i}}>1\right)$ or decreased $\left(\mathrm{F}_{\mathrm{f}} / \mathrm{F}_{\mathrm{i}}<1\right)$ after the treatments. Figure 2 shows the relationship between the level of pastiness and its hardness ratio for each of the 108 samples under study; these were grouped according to the temperature applied (40 or $50{ }^{\circ} \mathrm{C}$ ) since, as already mentioned, the effect of ultrasound was statistically negligible $(\mathrm{p}>0.05)$. It has to be remarked 
that $98 \%$ of the hardness ratios at $50{ }^{\circ} \mathrm{C}$ were over one, indicating that heating caused an overall increase in hardness. However, when samples were heated at $40{ }^{\circ} \mathrm{C}$, the hardness ratio was scattered around one. Thus, only $62 \%$ of the samples heated at $40{ }^{\circ} \mathrm{C}$ presented a ratio of more than one. Thereby, an average hardness ratio of $1.22 \pm 0.51$ was found for the samples heated at $40{ }^{\circ} \mathrm{C}$, which was significantly ( $\mathrm{p}<0.05$ ) smaller than that found at $50{ }^{\circ} \mathrm{C}, 2.72 \pm 0.85$ (Figure 2). Therefore, the temperature played a relevant role in the increase in hardness provoked by the mild thermal treatment. These results agree with those previously reported by Morales et al. (2008), who stored BF muscle parallelepipeds ( $20 \times 20 \times 15 \mathrm{~mm}$ ) wrapped in film for $24 \mathrm{~h}$ at temperatures from 4 to $46^{\circ} \mathrm{C}$. They found that the hardness values increased from 17.3 to $26.9 \mathrm{~N}$ when the temperature rose from 36 to $46^{\circ} \mathrm{C}$.

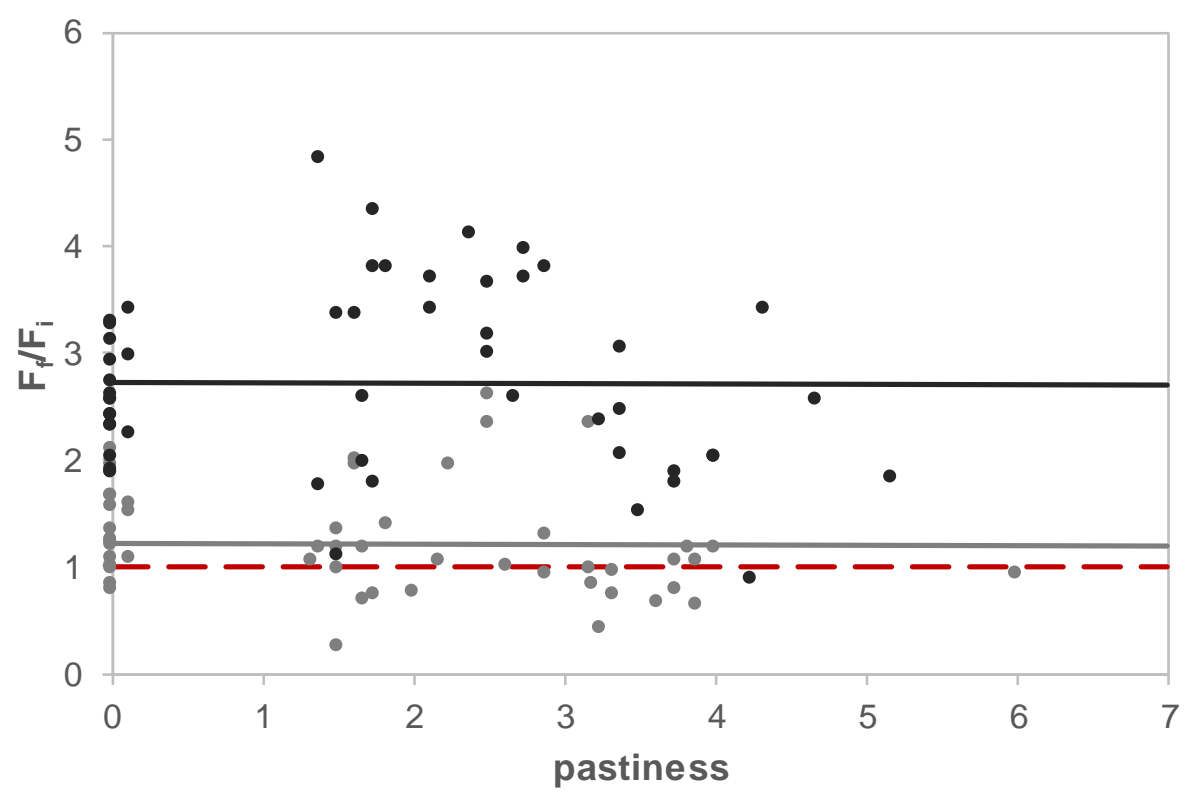

Figure 2. Relationship between pastiness and hardness ratio $\left(F_{f} / F_{i}\right)$ of dry-cured ham heated at 40 $(\bullet)$ and $50(\bullet){ }^{\circ} \mathrm{C}$. F $F_{\mathrm{i}}$ and $\mathrm{F}_{\mathrm{f}}$ are the initial and final sample hardness values, respectively. Points from both conventional (CV) and ultrasonically-assisted (PuS) experiments are shown together. Lower and upper continuous lines show average $F_{f} / F_{i}$ for 40 and $50{ }^{\circ} \mathrm{C}$ treatments, respectively, and dashed line shows $\mathbf{F}_{\mathrm{f}} / \mathrm{F}_{\mathrm{i}}$ equal to one.

As observed in Figure 2, level of pastiness did not have a statistically significant ( $\mathrm{p}>0.05$ ) effect on the hardness ratio; notwithstanding this, at $50{ }^{\circ} \mathrm{C}$ it was observed that the highest ratios belonged to the sample group with medium pastiness (Table 1). Therefore, for each temperature, ham samples experienced a similar relative variation in hardness when subjected to the mild thermal treatment, regardless of their initial pastiness. There have been no previous references to the impact caused by the mild thermal treatments on the textural attributes of samples differing in pastiness intensity. 


\subsubsection{Influence of the thermal treatment on elastic behavior}

The material relaxation when subjected to prior compression stress was analyzed as an indicator of elastic behavior since an ideal elastic material would have a force decay of 0 . Thereby, the higher the force decay, the more relevant the viscoelasticity (Eq. 1). Figure 3 plots the $\mathrm{Y}_{90, \mathrm{f}} / \mathrm{Y}_{90, \mathrm{i}}$ ratio according to the pastiness of every dry-cured ham slice, showing the same pattern as the one found for the $\mathrm{Y}_{2, \mathrm{f}} / \mathrm{Y}_{2, \mathrm{i}}$ ratio (data not shown). At $50{ }^{\circ} \mathrm{C}, 100 \%$ of the treated samples showed a $\mathrm{Y}_{90, \mathrm{f}} / \mathrm{Y}_{90, \mathrm{i}}$ ratio of under one, which points to the fact that elasticity increased after the treatment. Otherwise, $90 \%$ of dry-cured ham samples heated at $40{ }^{\circ} \mathrm{C}$ presented a $\mathrm{Y}_{90, \mathrm{f}} / \mathrm{Y}_{90, \mathrm{i}}$ ratio of below one. The average values of $\mathrm{Y}_{90, \mathrm{f}} / \mathrm{Y}_{90, \mathrm{i}}$ were $0.96 \pm 0.04$ and $0.86 \pm 0.06$ at 40 and $50{ }^{\circ} \mathrm{C}$, respectively. The lower value of $\mathrm{Y}_{90, \mathrm{f}} / \mathrm{Y}_{90, \mathrm{i}}$ at $50{ }^{\circ} \mathrm{C}$ reflects the fact that the treatment at this temperature was more effective at improving elasticity than at $40{ }^{\circ} \mathrm{C}$. The effect of temperature is also shown in Table 1 since, for the three levels of pastiness and for both CV and PuS, $\mathrm{Y}_{90, \mathrm{f}} / \mathrm{Y}_{90, \mathrm{i}}$ and $\mathrm{Y}_{2, \mathrm{f}} / \mathrm{Y}_{2, \mathrm{i}}$ ratios were always significantly $(\mathrm{p}<0.05)$ lower at 50 than at $40{ }^{\circ} \mathrm{C}$. In the aforementioned study published by Morales et al. (2008), a reduction of $\mathrm{Y}_{90}$ in ham was found as the treatment temperature increased from $36(0.621)$ to $46{ }^{\circ} \mathrm{C}(0.575)$. Gou et al. (2008) also reported a reduction of $\mathrm{Y}_{2}$ in ham when the ageing temperature was increased from 18 (0.339) to $30^{\circ} \mathrm{C}(0.318)$, which again supports the experimental results shown in Figure 3. Therefore, the 5 hour-long mild thermal treatment at $50^{\circ} \mathrm{C}$ emerges as a simple and reliable means of correcting softness and elasticity loss of dry-cured ham. Thus, heating would improve not only consumer perception during mastication but also industrial slicing.

The statistical analysis revealed that both the temperature and the level of pastiness had a significant effect on $\mathrm{Y}_{90, \mathrm{f}} / \mathrm{Y}_{90, \mathrm{i}}$ ratio $(\mathrm{p}<0.05)$ (Table 1). When samples were grouped into three levels of pastiness (Table 1), it was found that the $\mathrm{Y}_{90, \mathrm{f}} / \mathrm{Y}_{90, \mathrm{i}}$ ratio was the lowest in the group with no pastiness and the highest in the group with high pastiness, while intermediate values were found for the samples with medium pastiness. As an example, at $50{ }^{\circ} \mathrm{C}$ in PuS experiments, the $\mathrm{Y}_{90, \mathrm{f}} / \mathrm{Y}_{90, \mathrm{i}}$ ratio ranged from $0.81 \pm 0.03$ in the group with no pastiness to $0.92 \pm 0.03$ in the one with high pastiness, $0.84 \pm 0.03$ being the ratio for samples with medium pastiness. The same behavior was found for the $\mathrm{Y}_{2, \mathrm{f}} / \mathrm{Y}_{2, \mathrm{i}}$ ratio, as illustrated in Table 1. Therefore, the capacity of the mild thermal treatment to improve elastic behavior was moderately reduced as the pastiness increased. This could be due to the more intense effect of the thermal treatment on the proteins of non-pasty samples, since they retain the native structure (Coll-Brasas et al., 2019). 


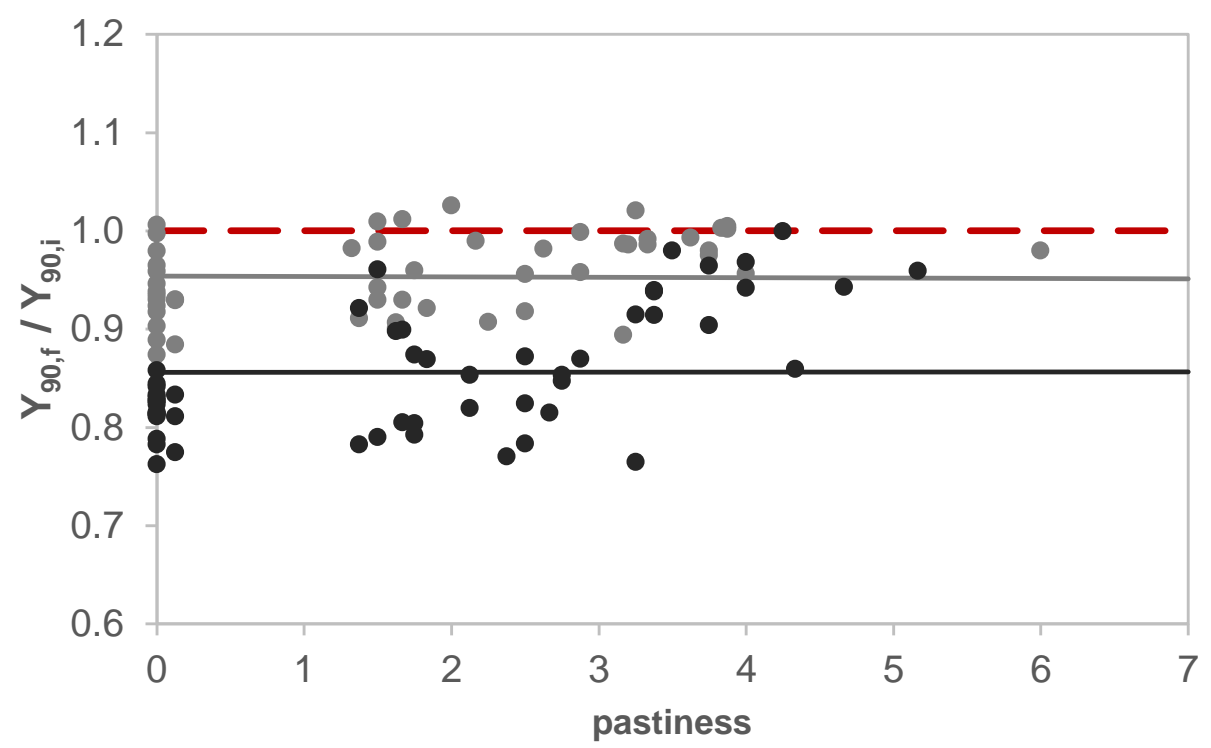

Figure 3. Relationship between pastiness and elasticity ratio $\left(\mathrm{Y}_{90, \mathrm{f}} / \mathrm{Y}_{90, \mathrm{i}}\right)$ of dry-cured ham heated at $40(\bullet)$ and $50(\bullet){ }^{\circ} \mathrm{C} . \mathrm{Y}_{90, \mathrm{i}}$ and $\mathrm{Y}_{90, \mathrm{f}}$ are the initial and final sample elasticity values, respectively, at the end of the compression test (90 s). Points from both conventional (CV) and ultrasonicallyassisted (PuS) experiments are shown together. Upper and lower continuous lines show average $\mathrm{Y}_{90, \mathrm{f}} / \mathrm{Y}_{90, \mathrm{i}}$ for 40 and $50{ }^{\circ} \mathrm{C}$ treatments, respectively, and dashed line shows $\mathrm{Y}_{90, \mathrm{f}} / \mathrm{Y}_{90, \mathrm{i}}$ equal to one.

\subsubsection{Influence of the treatment on adhesiveness}

The modification of adhesiveness brought about by the thermal treatment was computed by instrumental texture analysis. Mild thermal treatment led to relevant modifications of adhesiveness; thus, its ratio $\left(\mathrm{A}_{\mathrm{f}} / \mathrm{A}_{\mathrm{i}}\right)$ was below one for every sample (Figure 4$)$. This indicates that slice adhesiveness was reduced after heating, regardless of the conditions. Morales et al. (2008) also found a decrease in the adhesiveness of dry-cured ham BF muscle after a $168 \mathrm{~h}$ thermal treatment at $30{ }^{\circ} \mathrm{C}$. Similarly, Pérez-Santaescolástica et al. (2018) also reported a decrease in adhesiveness between control $(0.84 \mathrm{~N})$ and conventionally heated ham samples $(0.38 \mathrm{~N})$. Unlike the trend observed in hardness and elasticity, a multifactor ANOVA showed that neither the temperature nor the level of pastiness influenced the adhesiveness ratio significantly $(p>0.05)$. What should be highlighted is the great performance of the mild thermal treatment in the reduction of slice adhesiveness, since the ratios were around 0.5 in every case (Table 1). This confirms that adhesiveness was reduced by $50 \%$, which represents an excellent result since adhesiveness is one of the main issues related to consumer rejection of pasty dry-cured ham. The adhesiveness decrease after the mild thermal treatment could be explained by denaturation and other structural changes in the proteins. 


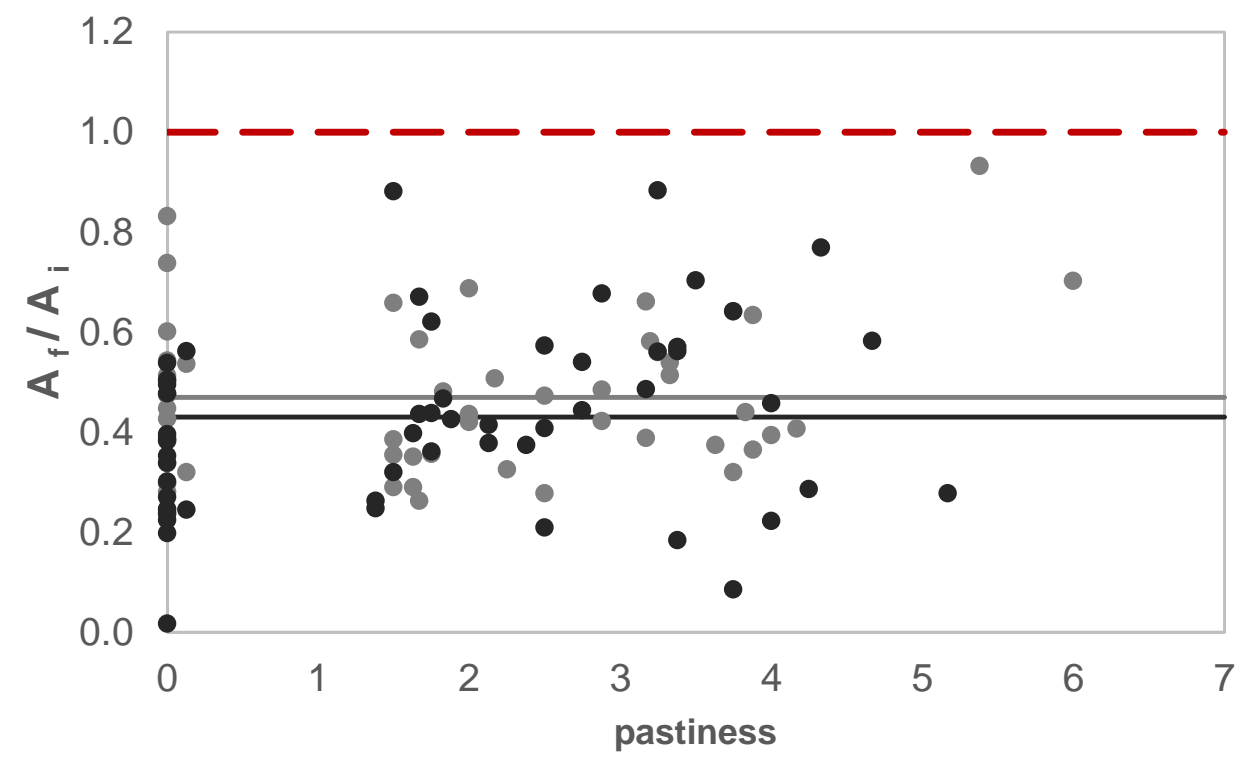

Figure 4. Relationship between pastiness and adhesiveness ratio $\left(\mathrm{A}_{\mathrm{f}} / \mathrm{A}_{\mathrm{i}}\right)$ of dry-cured ham heated at $40(\bullet)$ and $50(\bullet){ }^{\circ} \mathrm{C} . \mathrm{A}_{\mathrm{i}}$ and $\mathrm{A}_{\mathrm{f}}$ are the initial and final sample adhesiveness values, respectively. Points from both conventional (CV) and ultrasonically-assisted (PuS) experiments are shown together. Upper and lower continuous lines show average $A_{f} / A_{i}$ for 40 and $50{ }^{\circ} \mathrm{C}$ treatments, respectively, and dashed line shows $A_{f} / A_{i}$ equal to one.

\subsection{Effect of mild thermal treatment at $50^{\circ} \mathrm{C}$ on dry-cured ham microstructure}

As the most relevant textural modifications in dry-cured ham were observed for treatments at $50{ }^{\circ} \mathrm{C}$, microstructural analysis only focused on these samples. In general terms, the muscle tissue of non-pasty dry-cured ham BF muscle (Figure 5A) was formed by cells that maintained their structural individuality despite manufacturing adopting a compact appearance. However, in some areas, small gaps were observed due to myofibrillar protein denaturation, which causes the loss of its three-dimensional conformation, a typical consequence of the salt action (Mora et al., 2013). Z-disks were visible, although they were not aligned (Figure 6A) (Larrea et al., 2007). Practically the whole length of the sarcomere seemed to be occupied by an A band. The treatment carried out at $50{ }^{\circ} \mathrm{C}$ did not seem to affect the structural integrity of no pastiness dry-cured ham negatively (Figure 5B). In the heated samples, more empty intercellular spaces could be observed (Figure 5A) and some structural elements, such as I and A bands, could be differentiated more clearly in the cellular inner (Figure 6B) if compared to the ham structure before the treatment (Figure 6A). Z-disks still had the characteristic discontinuity originated from the curing process (Picouet et al., 2012). In summary, for non-pasty ham, the effect of the treatment on the microstructure was very light. Likewise, Contreras et al. (2020) analyzed the micro and ultrastructure of medium (Figure 5C and Figure 6C) and high pastiness (Figure 5E and Figure 6E) dry-cured ham and manifested that exists a large myofibrillar disintegration compared 
to the non-pasty ham. As increase the level of pastiness, the muscle tissue is converted in an unstructured protein matrix with many disintegrated areas and intercellular spaces (Contreras et al., 2020). Similar results were obtained by Fulladosa et al. (2017), who used LM to observe drycured ham with a high proteolysis index (47\%) but that had been induced artificially by a protease enzyme.

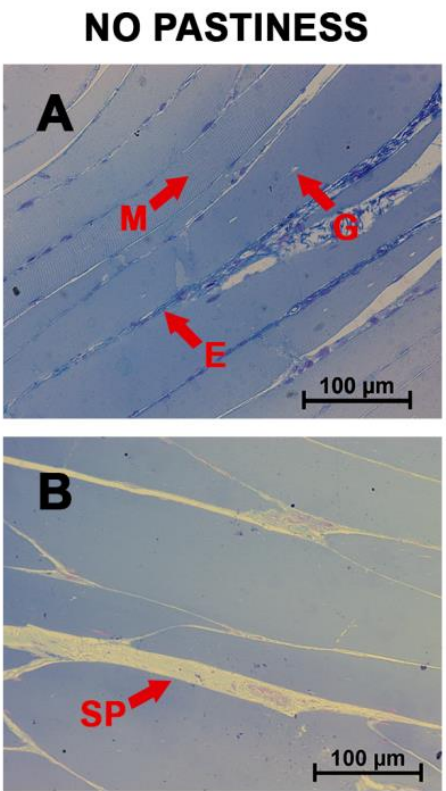

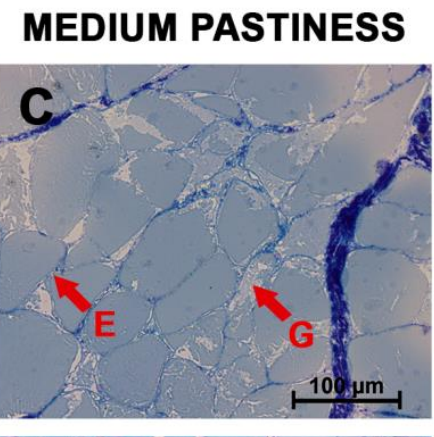

\section{HIGH PASTINESS}
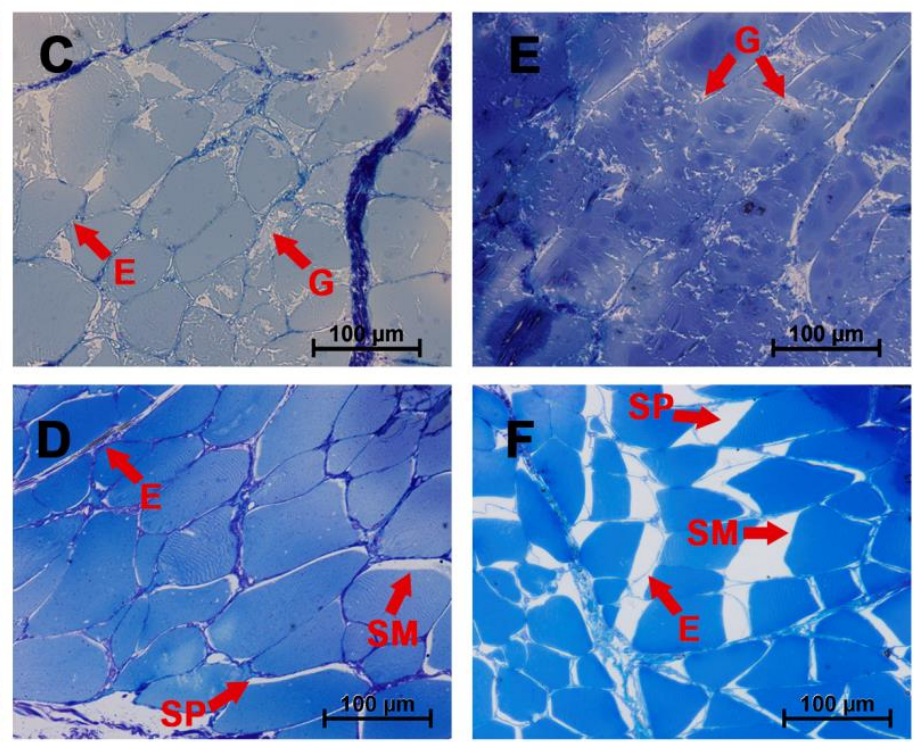

Figure 5. LM micrographs of muscle tissue, Biceps femoris, from dry-cured ham with different levels of pastiness before and after treatment carried out at $50{ }^{\circ} \mathrm{C}$ with $\mathrm{PuS}$ application (Before treatment: A, C, E; After treatment: B, D, F; Magnification: 20x). E: Endomysium; G: Gap; M: Myofibril; SM: Shrunk Myofibrils; SP: Intercellular Space.

In medium pasty ham, the mild thermal treatment seemed to produce the structuring of the muscle. Before treatment, muscle cells presented significant disintegration (Figure 5C); however, after the heat treatment, the muscle cells were less disintegrated, with better myofibrillar bundling (Figure 5D). Furthermore, the endomysium tissue seemed to be less shattered. Myofibril-sarcolemma unions were unattached in some areas, leading to the myofibrils shrinking inside the muscle cell, giving rise to empty intercellular spaces. This shrinkage, and thereby the tissue compaction (Tornberg, 2005), could somehow be responsible for the increase in the hardness and elasticity provoked by the treatment. As regards the ultrastructure of the ham (Figure 6 , D), an enhancement in the myofibrillar structure was found since the limits between myofibrils were more easily distinguished and sarcomere structures such as I and A bands seemed more organized. 
NO PASTINESS
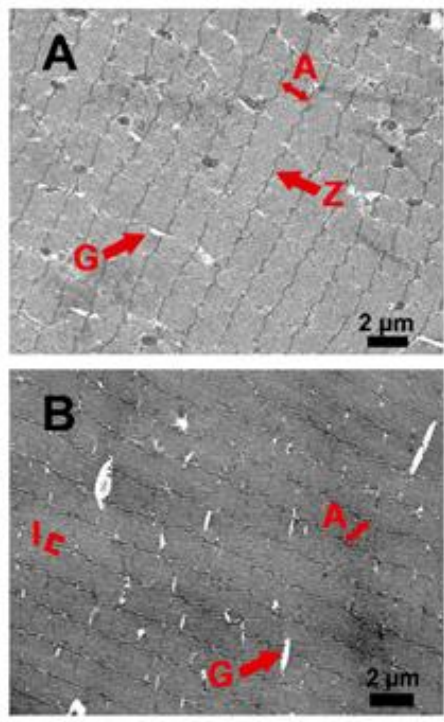

MEDIUM PASTINESS

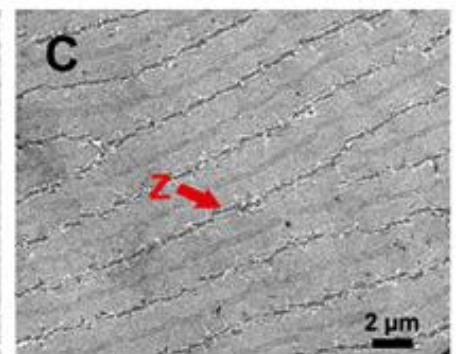

HIGH PASTINESS
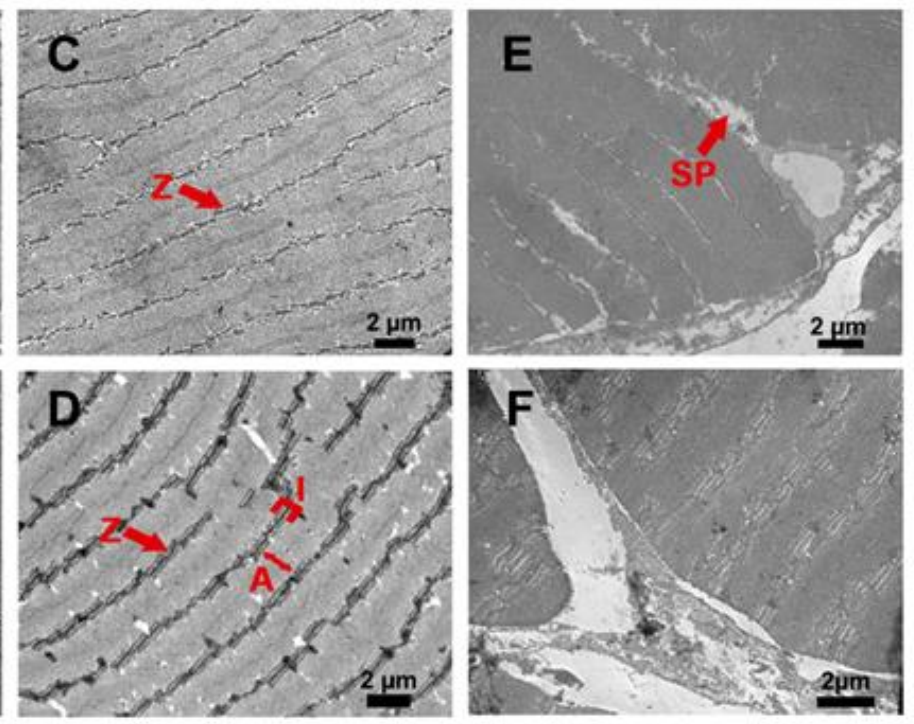

Figure 6. TEM micrographs of muscle tissue, Biceps femoris, from dry-cured ham with different levels of pastiness before and after treatment carried out at $50{ }^{\circ} \mathrm{C}$ with $\mathrm{PuS}$ application (Before treatment: A, C, E; After treatment: B, D, F; Magnification: 1200x). A: A band; G: Gap; I: I band; SP: Intercellular Space; Z: Z disk.

The heat treatment of dry-cured ham with high pastiness provoked substantial changes in the muscle structure. The tissue seemed to be more organized than before the treatment, structured in individual cells surrounded by endomysium connective tissue with a high enough degree of integrity (Figure 5, F). However, some myofibril-sarcolemma joints disappeared and the myofibrils seemed to be retracted into the cellular inner to a greater extent than in ham with medium pastiness after treatment. As a consequence, large empty intercellular spaces were created between myofibrils and endomysium convective tissue. As mentioned previously, the increase in hardness and more elastic behavior in ham after heat treatment could be closely related with the myofibrillar shrinkage. As for the ultrastructure of the ham with high pastiness after the treatment, some sarcomere structures could be appreciated; notwithstanding this, they were highly distended (Figure 6, F).

\section{Conclusions}

Mild thermal treatments in liquid medium emerge as a reliable, affordable and simple strategy to modify the textural properties in dry-cured ham. The performance of the thermal treatment was dependent on the temperature applied; thus, the higher the temperature, the greater the effect on the texture. The application of PuS during heating, which could be used to accelerate the process, did not involve any additional textural change. Thermally-treated samples were harder, more elastic in their behavior and less adhesive. Thereby, softness and adhesiveness, 
which are the typical problems related to pastiness, were improved by the thermal treatment. In general terms, the magnitude of the observed effects on the textural parameters was not linked to the level of pastiness of the dry-cured ham. Micro and ultrastructural analyses revealed that the thermal treatment caused substantial modifications in ham structure, such as the shrinkage of myofibrils in pasty hams, which helped to explain the reported textural effects. Future studies should address different aspects. Firstly, the impact of the thermal treatments on sensory properties and the assessment of the inherent microbial risks has to be necessarily analyzed. Secondly, the extension of the mild thermal treatments to whole hams also has to be explored. Finally, although the thermal treatment has to be limited to defective hams, it should be elucidated if the increase in hardness caused in non-pasty hams may negatively affect the consumer acceptance.

\section{Acknowledgements}

The authors acknowledge the financial support from the "Spanish Ministerio de Economía y Competitividad (MINECO), Instituto Nacional de Investigación y Tecnología Agraria y Alimentaria (INIA)" in Spain, European Regional Development Fund (ERDF 20142020) (Project RTA2013-00030-C03-02) and the PhD grant of M. Contreras from the Universitat Politècnica de València.

\section{References}

Arnau, J., Guerrero, L., \& Sárraga, C. (1998). The effect of green ham pH and $\mathrm{NaCl}$ concentration on cathepsin activities and the sensory characteristics of dry-cured hams. Journal of the Science of Food and Agriculture, 77, 387-392.

ASTM STP 758. (1981). American Society for Testing and Materials. Guidelines for the selection and training of sensory panel members.

Bermúdez, R., Franco, D., Carballo, J., \& Lorenzo, J. M. (2014). Physicochemical changes during manufacture and final sensory characteristics of dry-cured Celta ham. Effect of muscle type. Food Control, 43, 263-269.

Cilla, I., Martínez, L., Beltrán, J. A., \& Roncalés, P. (2005). Factors affecting acceptability of drycured ham throughout extended maturation under "bodega" conditions. Meat Science, 69, 789-795.

Coll-Brasas, E., Arnau, J., Gou, P., Lorenzo, J. M., García-Pérez, J. V., \& Fulladosa, E. (2019). Effect of high pressure processing temperature on dry-cured hams with different textural characteristics. Meat Science, 152, 127-133.

Contreras, M., Benedito, J., Bon, J., \& Garcia-Perez, J. V. (2018a). Accelerated mild heating of 
dry-cured ham by applying power ultrasound in a liquid medium. Innovative Food Science and Emerging Technologies, 50, 94-101.

Contreras, M., Benedito, J., Bon, J., \& Garcia-Perez, J. V. (2018b). Intensification of heat transfer during mild thermal treatment of dry-cured ham by using airborne ultrasound. Ultrasonics Sonochemistry, 41, 206-212.

Contreras, M., Benedito, J., Quiles, A., Lorenzo, J. M., Fulladosa, E., Gou, P., \& Garcia-Perez, J. V. (2020). Assessing the textural defect of pastiness in dry-cured pork ham using chemical, microstructural, textural and ultrasonic analyses. Journal of Food Engineering, 265, 109690.

Fulladosa, E., Rubio-Celorio, M., Skytte, J. L., Muñoz, I., \& Picouet, P. (2017). Laser-light backscattering response to water content and proteolysis in dry-cured ham. Food Control, 77, 235-242.

Garcia-Garrido, J. A., Quiles-Zafra, R., Tapiador, J., \& Luque De Castro, M. D. (1999). Sensory and analytical properties of Spanish dry-cured ham of normal and defective texture. Food Chemistry, 67, 423-427.

Garcia-Gil, N., Santos-Garcés, E., Fulladosa, E., Laverse, J., Del Nobile, M. A., \& Gou, P. (2014). High pressure induces changes in texture and microstructure of muscles in dry-cured hams. Innovative Food Science and Emerging Technologies, 22, 63-69.

Gou, P., Morales, R., Serra, X., Guàrdia, M. D., \& Arnau, J. (2008). Effect of a 10-day ageing at $30{ }^{\circ} \mathrm{C}$ on the texture of dry-cured hams processed at temperatures up to $18{ }^{\circ} \mathrm{C}$ in relation to raw meat $\mathrm{pH}$ and salting time. Meat Science, 80, 1333-1339.

Kang, D., Gao, X., Ge, Q., Zhou, G., \& Zhang, W. (2017). Effects of ultrasound on the beef structure and water distribution during curing through protein degradation and modification. Ultrasonics Sonochemistry, 38, 317-325.

Lacivita, V., Conte, A., Musavian, H. S., Krebs, N. H., Zambrini, V. A., \& Del Nobile, M. A. (2018). Steam-ultrasound combined treatment: A promising technology to significantly control mozzarella cheese quality. LWT - Food Science and Technology, 93, 450-455.

Larrea, V., Pérez-Munuera, I., Hernando, I., Quiles, A., Llorca, E., \& Lluch, M. A. (2007). Microstructural changes in Teruel dry-cured ham during processing. Meat Science, 76, 574582.

López-Pedrouso, M., Pérez-Santaescolástica, C., Franco, D., Fulladosa, E., Carballo, J., Zapata, C., \& Lorenzo, J. M. (2018). Comparative proteomic profiling of myofibrillar proteins in dry-cured ham with different proteolysis indices and adhesiveness. Food Chemistry, 244, $238-245$.

Lyng, J. G., Allen, P., \& McKenna, B. M. (1997). The influence of high intensity ultrasound baths on aspects of beef tenderness. Journal of Muscle Foods, 8, 237-249.

Lyng, J. G., Allen, P., \& McKenna, B. M. (1998). The effect on aspects of beef tenderness of preand post-rigor exposure to a high intensity ultrasound probe. Journal of the Science of Food 
and Agriculture, 78, 308-314.

Mora, L., Fraser, P. D., \& Toldrá, F. (2013). Proteolysis follow-up in dry-cured meat products through proteomic approaches. Food Research International, 54, 1292-1297.

Morales, R., Arnau, J., Serra, X., Guerrero, L., \& Gou, P. (2008). Texture changes in dry-cured ham pieces by mild thermal treatments at the end of the drying process. Meat Science, 80 , 231-238.

Pérez-Santaescolástica, C., Carballo, J., Fulladosa, E., Garcia-Perez, J. V., Benedito, J., \& Lorenzo, J. M. (2018). Application of temperature and ultrasound as corrective measures to decrease the adhesiveness in dry-cured ham. Influence on free amino acid and volatile compound profile. Food Research International, 114, 140-150.

Picouet, P. A., Sala, X., Garcia-Gil, N., Nolis, P., Colleo, M., Parella, T., \& Arnau, J. (2012). High pressure processing of dry-cured ham: Ultrastructural and molecular changes affecting sodium and water dynamics. Innovative Food Science and Emerging Technologies, 16, 335340.

Sun, Q., Zhao, X., Zhang, C., Xia, X., Sun, F., \& Kong, B. (2019). Ultrasound-assisted immersion freezing accelerates the freezing process and improves the quality of common carp (Cyprinus carpio) at different power levels. LWT - Food Science and Technology, 108, 106112.

Tornberg, E. (2005). Effects of heat on meat proteins - Implications on structure and quality of meat products. Meat Science, 70, 493-508.

Xiong, G. Y., Zhang, L. L., Zhang, W., \& Wu, J. (2012). Influence of ultrasound and proteolytic enzyme inhibitors on muscle degradation,tenderness, and cooking loss of hens during aging. Czech Journal of Food Sciences, 30, 195-205. 



\section{GENERAL DISCUSSION}



Dry-cured ham is a typical meat product of Spanish market highly appreciated by consumers. The high heterogeneity of raw ham and the multiple manufacturing factors can cause the development of textural defects. One of the main texture problems is the appearance of pastiness, which is defined as an unusual softness with an intense viscous mechanical behavior, which produces a mouth-coating sensation during the mastication and might lead to consumer's rejection. Traditional methods to characterize pastiness are time-consuming, inaccurate and destructive. In this regard, the use of new technologies, such as ultrasound, could contribute to a faster and better characterization of defective textures in dry-cured hams in a non-destructive way. In the present thesis, this non-destructive characterization was addressed on the one hand, by monitoring the appearance of the defect during ham manufacturing and on the other hand, by the inspection of the final product. Furthermore, the development of alternative processing methods to correct pastiness is also largely relevant to mitigate the intensity of the defect and therefore its study was considered in the present work.

\section{Textural characterization of ham}

\section{Manufacturing monitoring using ultrasound}

Ultrasound is a non-destructive technology already used to characterize different properties of meat products (Corona et al., 2013a; de Prados et al., 2015a, 2016). In this sense, in the present thesis, hams were ultrasonically monitored by measuring the ultrasonic velocity in order to identify the appearance of the pastiness textural defect during manufacturing. For that purpose, a customized manufacturing was designed and carried out to reach a wide range of moisture, salt content and pastiness defect levels. The selection of the ultrasonic velocity as the response parameter was based on previous literature because of its satisfactory correlation with textural parameters (Corona et al., 2013a). In addition, the measurement of the ultrasonic attenuation in large solid samples with non-regular surface is complex due to the difficult assessment of the energy loss on the transducer-sample surface interface. Ultrasonic measurements showed a progressive increase in the ultrasonic velocity as manufacturing progressed (average of 1536, 1557, 1587 and $1713 \mathrm{~m} / \mathrm{s}$ in raw ham, after salting, after post-salting and at the end of the manufacturing, respectively), mainly as a consequence of the salt gain and the moisture loss (Fulladosa et al., 2015; Garcia-Perez et al., 2019). However, the ultrasonic velocity was not able to detect the appearance of pastiness during processing, neither to discriminate dry-cured ham according to its pastiness level at the end of the manufacturing. In this regard, the expected influence of pastiness on the ultrasonic velocity could be masked by the large impact of the compositional changes on this ultrasonic parameter. Moreover, other 
ultrasonic parameters, such as attenuation, which were not considered in this work in whole hams for technical reasons, might be more appropriate.

\section{Post-salting monitoring using ultrasound}

Dry-cured ham post-salting monitoring was addressed using ultrasound and analyzing the changes in weight, internal composition and texture. The variation of the ham weight during the post-salting was satisfactorily $(\mathrm{r}=0.95 ; \mathrm{p}<0.05)$ described by the variation of the ultrasonic velocity. Moisture content diminished during post-salting because of the differences between the relative humidity of the air in the chamber and the water activity of the ham; however, there were no moisture differences between the internal (closer to the subcutaneous fat surface and comprising mainly the Biceps femoris (BF) muscle) and the external zone (closer to the lean surface and comprising mainly the Semimembranosus muscle) of the ham section. The decrease of moisture during post-salting led to an increase in the salt content, being always the salt content higher in the external zone of the ham due to the direction followed by the salt diffusion. In this sense, a significant $(\mathrm{p}<0.05)$ linear relationship was found between the ultrasonic velocity and the salt and moisture content ( $\mathrm{r}=0.93$ and $\mathrm{r}=0.86$, respectively) during the post-salting. Similar results were obtained by de Prados et al. (2016) during ham salting where the ultrasonic velocity allowed to satisfactorily predict and monitor in real time the salt gain and moisture loss. Notwithstanding, although hardness was always greater in the external zone, no significant ( $p>0.05)$ changes in the ham texture were found during post-salting. Therefore, the non-significant ham hardness variation during post-salting confirmed that the aforementioned great rise of the ultrasonic velocity was mainly caused by the moisture decrease and the salt redistribution.

\section{Identification of texture defects in dry-cured ham by conventional and ultrasound techniques}

An exhaustive evaluation of dry-cured ham slices with different levels of pastiness was performed using conventional destructive analysis by assessing its composition, proteolysis index, texture and microstructure. According to the customized manufacturing process followed, hams' pastiness level was independent of the salt and moisture content, unlike in the industry, where normally pastiness is developed in samples with a low amount of salt. Pasty samples presented the highest proteolysis index (38.7\%), exhibited a more relevant structural degradation and consequently, were the softest (hardness $=5.4 \mathrm{~N}$ ) and presented the most intense viscous behavior $\left(\mathrm{Y}_{90}=0.434\right)$. However, a high degree of experimental variability was found for every pastiness level, which confirmed the high complexity of pastiness defect and the difficulty of its adequate characterization, even using conventional destructive methods.

The non-destructive assessment of ham slices carried out with low intensity ultrasound confirmed that the ultrasonic attenuation was significantly $(\mathrm{p}<0.05)$ higher in pasty hams (average 
of $48 \mathrm{~Np} / \mathrm{m}$ compared to the $43 \mathrm{~Np} / \mathrm{m}$ of the non-pasty samples), which might be linked to the more viscous nature of its structure which leads to a greatest damping phenomenon during wave propagation (You et al., 1991). This fact increases the loss of energy during wave propagation as pastiness intensity increases. Ayadi et al. (2007) also found that the meat texture was related with the ultrasonic attenuation since the increase in the rigidity of BF muscles of beef cattle during the onset of rigor-mortis provoked a reduction of the attenuation. However, in the present thesis, ultrasonic velocity in ham slices was not related to their pastiness level.

Taking into account the studies performed in this work to non-destructively characterize the texture of dry-cured ham, it could be concluded that the ultrasonic velocity, in both whole and sliced dry-cured ham, was mainly related with the ham composition. Therefore, although the ultrasonic velocity has been used to characterize the texture of different meat products (Corona et al., 2013a; Koch et al., 2011), the textural changes provoked by the appearance of pastiness are undetectable by the ultrasonic velocity which is much more influenced by compositional (moisture and salt contents) differences among samples. As regards the relationship between the ultrasonic attenuation and the ham texture, it was found that the pastiness level in sliced dry-cured ham influenced the response of the ultrasonic attenuation, which could be used for non-destructive pastiness detection in ham slices. Therefore, future work should focus on the development of new technological alternatives to solve the coupling problems between the transducer and samples with irregular surfaces. This could allow to measure the ultrasound attenuation in larger and irregular-surface samples, such as whole dry-cured hams, which could be used to detect and classify whole hams according to their pastiness levels. An alternative to improve transducer/sample coupling could be the use of air-coupled ultrasound.

\section{Development of air-coupled ultrasonic techniques to characterize dry-cured ham texture}

Air-coupled ultrasonic techniques (through transmission and pulse-echo mode) were developed for the contactless characterization of dry-cured ham texture in whole ham pieces and slices. Apart from the non-destructive nature of ultrasound, the air-coupled techniques, where the sample is not in contact with the sample, allows a non-invasive measurement. This feature contributes to its industrial implementation since allows a faster measurement and avoids surface deformations in the food material, as well as cross-contamination. Future research should address the assessment of the reliability and accuracy of air-coupled techniques compared to traditional contact-ultrasound. 


\section{Improvement of ham texture using mild thermal treatments}

For the purpose of correcting defective textures of dry-cured hams, mild thermal treatments were performed at the end of the manufacturing. In order to intensify the heat transfer in dry-cured ham and hence, accelerate the heat treatments at industrial level, power ultrasound (PuS) was applied. As heating media, water and air were considered.

\section{Ultrasonic intensification of thermal treatments}

The heat treatments were carried out until the center of the BF muscle of the ham slice reached a target temperature, corresponding with $5{ }^{\circ} \mathrm{C}$ bellow the temperature of the heating medium. Firstly, the mild thermal treatments were performed in liquid medium because of the high heat transfer coefficient of water, compared to the one found in gas media. The influence of the ultrasonic application during heating was quantified by computing the apparent thermal diffusivity by means of a conduction model. Experimental results showed that the ultrasound application sped up the heat transfer significantly $(\mathrm{p}<0.05)$, shortening the heating process. Thus, the maximum reduction of treatment time was found when heating dry-cured ham at $40^{\circ} \mathrm{C}$ (from 17 to 9 min without and with PuS application, respectively). The heat conduction model proposed to describe the heating kinetics was adequate (explained variance above 98.6\%), which confirmed that ultrasound application leads to a negligible external resistance to heat transport due to the acoustic cavitation and microagitation, which are the main factors responsible of reducing heat transfer resistance by increasing fluid turbulence (Ashokkumar, 2011). These ultrasonic effects could be compared to the turbulence introduced into the medium by mechanical agitation when ultrasound was not applied. The apparent thermal diffusivity computed increased up to $51 \%$ when $\mathrm{PuS}$ were applied. However, the higher the temperature, the lower the ultrasonic intensification.

Secondly, the mild thermal treatments were carried out in gas medium, in pursuit of simplifying the process because of the energy saving by heating air instead of water and to reduce wastewater and possible microbial contaminations. In this case, the heat treatments were carried out until the center of the ham cylinder reached a temperature $5^{\circ} \mathrm{C}$ below the temperature of the heating medium. The application of PuS also sped up the heat transfer in air medium, showing, a significant $(\mathrm{p}<0.05)$ reduction of the heating time (i.e. from 25 to $16 \mathrm{~min}$ when heating at $50{ }^{\circ} \mathrm{C}$ and air velocity of $2 \mathrm{~m} / \mathrm{s}$, without and with the assistance of PuS, respectively). The analysis of the heat transfer by considering that it was entirely controlled by conduction was not satisfactory since the average explained variance obtained in the experiments performed was $94 \%$, hence the heat convection in the interface should be considered in future works. When PuS were applied, an increase in the apparent thermal diffusivity of up to $38 \%$ was obtained, which could be related to both the reduction of the external resistance to heat transfer due to microstirring provoked by PuS, which increases the fluid turbulence (Yao et al., 2015), and to the reduction of the internal 
resistance due to the compressions and expansions in the internal structure. As regards the influence of the process parameters in the heating kinetics, the higher the temperature, the greater the improvement in the apparent thermal diffusivity due to PuS application. Notwithstanding, the higher the air velocity, the lesser the improvement of the apparent thermal diffusivity, due to the disruption of the acoustic field caused by high air flow rates (García-Pérez et al., 2006b).

The effect that temperature had on PuS intensification depended on the heating medium. Thus, in the case of water medium, where intensification was focused on the enhancement of heat conduction and the conversion of mechanical into heat energy, higher temperatures could lead to a larger particle motion into the solid samples, minimizing the additional energy and improvement of heat conduction provided by PuS. Similar results were found by Lespinard et al. (2015), who studied the effect of ultrasonic-assisted blanching on heat transfer of mushrooms heated at different temperatures, finding out that the higher the temperature tested, the lower the PuS intensification and hence the lesser the improvement on the heat transfer coefficient (205 and $599 \%$ when heating at 90 and $60{ }^{\circ} \mathrm{C}$, respectively). On the contrary, after the experiments carried out in air, it was observed that higher temperatures reduced the air density, increasing the agitation of the air and provoking the ultrasound being more effective on the heat transfer intensification. Thus, for the treatments in water medium, the application of PuS improved the apparent thermal diffusivity by 51 and $20 \%$ when the treatments were performed at 40 and $50{ }^{\circ} \mathrm{C}$, respectively. On the other hand, the enhancement of the apparent thermal diffusivity due to the assistance of PuS in the experiments carried out in air at 40 and $50^{\circ} \mathrm{C}$ was 5 and $38 \%$, respectively.

\section{Correction of textural defects}

The aforementioned thermal treatments carried out in dry-cured ham until the target liquid or air temperature was reached in the center of the sample, provoked important changes in its texture. Thus, dry-cured ham became harder and with a higher elastic behavior. In this sense, the performance of slightly longer experiments increasing the treatment time by including a holding phase, could aid to improve the textural properties of hams. Thereby, hams with medium and high level of pastiness, as well as non-defective hams, were subjected not only to the heating until a target temperature was reached, but also to a holding phase until completing a total treatment time of 5 hours. Experiments were performed in liquid medium at 40 and $50{ }^{\circ} \mathrm{C}$ with and without the application of ultrasound in the heating phase. After the thermal treatment, treated and control samples were compared in terms of textural properties. The thermal treatment led to an increase of the hardness and a loss of viscous behavior, up to an average of 3.24 and 0.84 for the finalinitial ratio of hardness and viscous behavior, respectively, in medium pasty samples heated at 50

${ }^{\circ} \mathrm{C}$. Textural changes in hardness and viscous behavior were more noticeable at $50{ }^{\circ} \mathrm{C}$, and no effect of the ultrasound application during heating was found. Adhesiveness decreased after 
heating, reaching similar figures regardless the temperature used (average final-initial adhesiveness ratio of 0.45 ). Likewise, the thermal treatment provoked noticeable microstructural changes on the ham microstructure, among others, the more remarkable was the shrinkage of the myofibrils, which contributed to explain the reported textural changes. These results were consistent with Tornberg (2005) and Morales et al. (2008), who attributed the changes occurred in the ham texture after heating mainly to transversal and longitudinal shrinkage of meat myofibrils, in addition to aggregation of the globular heads of myosin and cell membrane disruption. In line with the texture changes suffered by pasty dry-cured ham after the thermal treatment found in this thesis, Coll-Brasas et al. (2019) also reported a change in the texture of hams with different levels of pastiness after high hydrostatic pressure treatments, which could also be partly linked to an increase in the temperature due to pressurization.

In conclusion, pastiness is a relevant and highly complex textural defect in dry-cured ham. On an industrial scale, low intensity ultrasound could be a promising technology to characterize, in a non-destructive way, dry-cured ham texture. Specifically, the ultrasonic attenuation was able to classify sliced dry-cured ham according to its pastiness level. In order to provoke textural changes in dry-cured ham and mitigate the defect of pastiness, mild thermal treatments in both liquid and gas media could be considered. Furthermore, the application of PuS during the heating phase of the thermal treatment could shorten the processing time. 


6. CONCLUSIONS 

According to the experimental results obtained and considering the structure of the present thesis, the main conclusions achieved are listed and grouped into four sections.

\section{Monitoring of dry-cured ham manufacturing}

- The ultrasonic velocity measured in whole hams increased during manufacturing due to the salt gain and the water loss. However, the appearance of pastiness defect was not detected by the ultrasonic velocity changes.

- The variation of the weight ham during the post-salting was satisfactorily related to the variation of the ultrasonic velocity. In addition, internal salt and moisture content were well depicted by the ultrasonic velocity.

- During the post-salting stage, texture modifications were undetectable.

\section{Assessment of pastiness defect in dry-cured ham}

- Highly pasty samples presented the largest proteolysis index and were the softest and most adhesive, evidencing their most intense viscous behavior. Notwithstanding, a high degree of variability was found in each of the parameters measured to assess dry-cured ham pastiness.

- In general terms, the microstructural analysis revealed that pasty hams presented a great degradation of the myofibrillar structure, showing a merged protein structure similar to a gel, with large gaps.

- The ultrasonic velocity was not related with the level of pastiness, which could be explained by the great influence of salt and moisture content on this parameter.

- The more intense viscous behavior of the pasty hams led to a higher ultrasonic attenuation in ham slices due to the damping phenomena experimented by the ultrasonic wave during its propagation, increasing from an average of $43.1 \mathrm{~Np} / \mathrm{m}$ in the non-pasty samples to $48.2 \mathrm{~Np} / \mathrm{m}$ in the hams with the highest pastiness level.

- Ultrasound technology should be adapted to measure the ultrasonic attenuation in large and irregular-surface samples in order to detect and classify whole dry-cured hams according to their pastiness level.

- Different air-coupled ultrasound techniques have been developed and tested for the characterization of textural properties in dry-cured ham pieces and slices. 


\section{Intensification of dry-cured ham mild thermal treatments by using power ultrasound}

- Power ultrasound sped up the heat transport during dry-cured ham mild thermal treatment, shortening the average heating time from 17 to $9 \mathrm{~min}$ and from 25 to $16 \mathrm{~min}$ in liquid and air treatments, respectively.

- Modelling of heating kinetics revealed that ultrasound application was able to improve both internal heat molecular conduction and external heat turbulent convection.

- The computed apparent thermal diffusivity was increased by power ultrasound application up to $51 \%$ and $37 \%$ for liquid and air medium, respectively.

- Mild thermal treatments showed the capacity to improve dry-cured ham texture, increasing the hardness and decreasing the viscous behavior of the samples, in a very short period of time.

\section{Correction of dry-cured ham pastiness by mild thermal treatments in liquid medium}

- Mild thermal treatments enhanced the texture of defective hams since the hardness increased and the viscous behavior was less intense, being the effect more noticeable at 50 than at $40{ }^{\circ} \mathrm{C}$. In addition, the adhesiveness of slices also diminished similarly, regardless the treatment temperature used. The performance of the thermal treatment was of similar magnitude at every pastiness level.

- The application of power ultrasound during the thermal treatment did not involve any additional change in the ham texture.

- The textural improvement is achieved in only $5 \mathrm{~h}$ of mild thermal treatment, which greatly improves its industrial implementation.

- The main effect of the mild thermal treatment on the dry-cured ham microstructure was the shrinkage of the meat myofibrils, which could explain the texture modifications observed.

\section{General conclusion}

Dry-cured ham manufacturing is a complex process where the development of defective textures, such as pastiness, can take place. Currently, as with the industrial manufacturing of numerous traditional products, there are not control systems able to evaluate non-destructively the evolution of the ham during processing. This online monitoring could improve the quality of the final product. Ultrasound inspection technology was not able to detect the appearance of pastiness along the manufacturing process. Notwithstanding, the measurement of ultrasonic 
attenuation allowed a feasible and non-destructive detection of pastiness defect in sliced dry-cured ham at the end of manufacturing. As for corrective actions of the textural defects, mild thermal treatments were validated as an affordable and simple strategy to improve the ham texture, turning pasty dry-cured hams into harder and less adhesive ones. Therefore, the mild thermal treatments could be a reasonable strategy for the industry to mitigate the defect of pastiness. 

7. RECOMMENDATIONS 

Based on the results obtained, the following aspects could be explored in future research work in order to complete the knowledge related to the topics addressed in this thesis:

\section{Pastiness in dry-cured ham}

- To deepen into the study of the proteolytic reactions and the biochemical mechanisms taking place during ham manufacturing and leading to the development of pastiness in dry-cured ham.

\section{Ultrasound for detecting dry-cured ham texture defects}

- To address the measurement of the ultrasonic attenuation in whole dry-cured hams to quantify the pastiness defect.

- To evaluate the use of air-coupled ultrasound in both through-transmission and pulseecho mode to characterize dry-cured ham texture.

- To assess the reliability and accuracy of air-coupled ultrasound to identify and quantify defective textures in sliced and whole dry-cured hams.

\section{Treatments for correcting dry-cured ham texture}

- To analyze whether the ultrasonic assisted mild heating in air medium could enhance the texture of dry-cured ham with pastiness defect and if that happens, to perform longer treatment times.

- To describe the heat transfer kinetics using a model that considers both conduction and convection heat transfer in both liquid and air media.

- To evaluate the use of power ultrasound during the whole thermal treatment, heating and holding phases, in both air and liquid media to shorten the time needed to achieve the texture modifications.

- To determine the mechanisms that occur during the thermal treatments that make drycured ham become harder, more elastic and less adhesive.

\section{Prospective applications of ultrasound in the dry-cured ham industry}

- To scale-up both contact and air-coupled ultrasound techniques for the characterization of dry-cured ham slices being transported on a conveyor belt.

- To select a treatment committed regarding economic and temporary resources to achieve optimum results in terms of dry-cured ham texture improvement using mild thermal treatments. 
- To design a procedure that allows the non-destructive ultrasonic detection of defective textures in ham to be integrated with the necessary thermal treatment for each ham piece analyzed. 


8. SCIENTIFIC CONTRIBUTION 



\section{Research papers}

Contreras, M., Benedito, J., Bon, J., Garcia-Perez, J.V. (2018). Intensification of heat transfer during mild thermal treatment of dry-cured ham by using airborne ultrasound. Ultrasonics - Sonochemistry, 41, 206-212.

Contreras, M., Benedito, J., Bon, J., Garcia-Perez, J.V. (2018). Accelerated mild heating of dry-cured ham by applying power ultrasound in a liquid medium. Innovative Food Science and Emerging Technologies, 50, 94-101.

Contreras, M., Benedito, J., Quiles, A., Lorenzo, J.M., Fulladosa, E., Gou, P., GarciaPerez, J.V. (2020). Assessing the textural defect of pastiness in dry-cured pork ham using chemical, microstructural, textural and ultrasonic analyses. Journal of Food Engineering, 265, 109690.

Contreras, M., Benedito, J., Quiles, A., Lorenzo, J.M., Fulladosa, E., Garcia-Perez, J.V. (2020). Correction of defective textures in packaged dry-cured pork ham by applying conventional and ultrasonically-assisted mild thermal treatments. LWT-Food Science and Technology, 126, 109283.

Contreras, M., Lorenzo, J.M., Fulladosa, E., Quiles, A., Benedito, J., García-Pérez, J.V. (2020). El defecto de pastosidad y su caracterización no destructiva y no invasiva mediante ultrasonidos. Eurocarne, 284, 56-66.

Contreras, M., Benedito, L., Garcia-Perez, J.V. Ultrasonic characterization of composition and texture modifications in dry-cured pork ham during post-salting. Meat Science. Submitted. 


\section{Contributions to congresses}

Contreras, M., Benedito, J., Mari-Martinez, G., Fulladosa, E., Garcia-Perez, J.V. (2016). Improvement of heat transfer during mild thermal treatment of dry-cured ham by using air-borne ultrasound. $18^{\text {th }}$ World Congress of Food Science and Technology (IUFoST). Dublin (Ireland).

Contreras, M., Benedito, J., Bellod, A., Bautista, M. Garcia-Perez, J.V. (2016). Texture enhancement in dry-cured ham by mild thermal treatment in liquid medium. $18^{\text {th }}$ World Congress of Food Science and Technology (IUFoST). Dublin (Ireland).

Contreras, Benedito, Pérez-Muelas, Fulladosa, Lorenzo, Garcia-Perez. (2017). Caracterización no destructiva del proceso de elaboración de jamón curado. IX Congreso Nacional de Ciencia y Tecnología de los Alimentos (CyTA/CESIA). Madrid (Spain).

Contreras, M., Benedito, J, Perez-Muelas, N., Fulladosa, E., Lorenzo, J.M., Garcia-Perez, J.V. (2017). Influencia del calentamiento en propiedades mecánicas de jamón curado. IX Congreso Nacional de Ciencia y Tecnología de los Alimentos (CyTA/CESIA). Madrid (Spain).

Contreras, M., Quiles, A., Benedito, J., Fulladosa, E., Pérez-Santaescolástica, C., GarciaPerez, J.V. (2017). Microstructure and ultrastructure of dry-cured ham with different intensity in pastiness defect. $46^{\text {th }}$ Annual Food Science and Technology Conference (IFSTI). Dublin (Ireland).

Contreras, M., Quiles, A., Benedito, J., Fulladosa, E., Lorenzo, J.M., Garcia-Perez, J.V. (2017). Structural improvement in dry-cured ham with high pastiness defect by mild thermal treatment. $46^{\text {th }}$ Annual Food Science and Technology Conference (IFSTI). Dublin (Ireland).

Contreras, M., Benedito, J., Garcia-Perez, J.V., Povey, M.J.W., Holmes, M. (2018). Evaluation of acoustic reflectometry as a tool to assess texture in dry-cured ham. $5^{\text {th }}$ Food Science \& Nutrition PhD Conference. Leeds (United Kingdom).

Contreras, M., Fariñas, M.D., Gómez Álvarez-Arenas, T., Benedito, J., Garcia-Perez, J.V. (2019). Uso de ultrasonidos sin contacto para analizar la textura de jamón curado. X Congreso Nacional de Ciencia y Tecnología de los Alimentos (CyTA/CESIA). León (Spain). 


9. REFERENCES 

Ahmad-Qasem, M. H., Cánovas, J., Barrajón-Catalán, E., Micol, V., Cárcel, J. A., \& GarcíaPérez, J. V. (2013). Kinetic and compositional study of phenolic extraction from olive leaves (var. Serrana) by using power ultrasound. Innovative Food Science and Emerging Technologies, 17, 120-129.

Akpinar, E. K., \& Toraman, S. (2016). Determination of drying kinetics and convective heat transfer coefficients of ginger slices. Heat and Mass Transfer/Waerme- Und Stoffuebertragung, 52, 2271-2281.

Alarcon-Rojo, A. D., Janacua, H., Rodriguez, J. C., Paniwnyk, L., \& Mason, T. J. (2015). Power ultrasound in meat processing. Meat Science, 107, 86-93.

Albarracín, W., Sánchez, I. C., Grau, R., \& Barat, J. M. (2011). Salt in food processing; usage and reduction: A review. International Journal of Food Science and Technology, 46, 13291336.

Aliño, M., Grau, R., Toldrá, F., \& Barat, J. M. (2010). Physicochemical changes in dry-cured hams salted with potassium, calcium and magnesium chloride as a partial replacement for sodium chloride. Meat Science, 86, 331-336.

Andrés, A. I., Cava, R., Ventanas, J., Thovar, V., \& Ruiz, J. (2004). Sensory characteristics of Iberian ham: Influence of salt content and processing conditions. Meat Science, 68, 45-51.

Antequera, T., Caro, A., Rodríguez, P. G., \& Pérez, T. (2007). Monitoring the ripening process of Iberian ham by computer vision on magnetic resonance imaging. Meat Science, 76, 561567.

AOAC. (1997). Official Methods 950.46 and 991.36. In Official Methods of Analysis (sixteenth ed.)

Arnau, J. (1993). Tecnología de elaboración del jamón curado. Microbiologia SEM, 9, 3-9.

Arnau, J., \& Gou, P. (2001). Effect of air relative humidity on ham rind and subcutaneous salted fat during the resting period. Meat Science, 58, 65-68.

Arnau, J., Gou, P., \& Comaposada, J. (2003). Effect of the relative humidity of drying air during the resting period on the composition and appearance of dry-cured ham surface. Meat Science, 65, 1275-1280.

Arnau, J., Guerrero, L., \& Gou, P. (1997). Effects of temperature during the last month of ageing and of salting time on dry-cured ham aged for six months. Journal of the Science of Food and Agriculture, 74, 193-198. 
Arnau, J., Guerrero, L., \& Sárraga, C. (1998). The effect of green ham $\mathrm{pH}$ and $\mathrm{NaCl}$ concentration on cathepsin activities and the sensory characteristics of dry-cured hams. Journal of the Science of Food and Agriculture, 77, 387-392.

Ashokkumar, M. (2011). The characterization of acoustic cavitation bubbles - An overview. Ultrasonics Sonochemistry, 18, 864-872.

ASTM STP 758. (1981). American Society for Testing and Materials. Guidelines for the selection and training of sensory panel members.

Ávila, M. M., Durán, M. L., Caballero, D., Antequera, T., Palacios-Pérez, T., Cernadas, E., \& Fernández-Delgado, M. (2019). Magnetic resonance imaging, texture analysis and regression techniques to non-destructively predict the quality characteristics of meat pieces. Engineering Applications of Artificial Intelligence, 82, 110-125.

Ayadi, A., Culioli, J., \& Abouelkaram, S. (2007). Sonoelasticity to monitor mechanical changes during rigor and ageing. Meat Science, 76, 321-326.

Ayadi, M. A., Makni, I., \& Attia, H. (2009). Thermal diffusivities and influence of cooking time on textural, microbiological and sensory characteristics of turkey meat prepared products. Food and Bioproducts Processing, 87, 327-333.

Bantle, M., \& Hanssler, J. (2013). Ultrasonic convective drying kinetics of clipfish during the initial drying period. Drying Technology, 31, 1307-1316.

Bañón, S., Gil, M. D., \& Garrido, M. D. (2003). The effects of castration on the eating quality of dry-cured ham. Meat Science, 65, 1031-1037.

Barat, J. M., Grau, R., Ibáñez, J. B., \& Fito, P. (2005). Post-salting studies in Spanish cured ham manufacturing. Time reduction by using brine thawing-salting. Meat Science, 69, 201-208.

Barat, J. M., Grau, R., Pagán-Moreno, M. J., \& Fito, P. (2004). Replacement of pile salting by simultaneous brine thawing-salting in Spanish cured ham manufacturing. Meat Science, 66, 603-608.

Barretto, T. L., Rodrigues Pollonio, M. A., Telis-romero, J., \& da Silva Barretto, A. C. (2018). Improving sensory acceptance and physicochemical properties by ultrasound application to restructured cooked ham with salt ( $\mathrm{NaCl}$ ) reduction. Meat Science, 145, 55-62.

Benali, M., \& Kudra, T. (2010). Process intensification for drying and dewatering. Drying Technology, 28, 1127-1135.

Benedini, R., Parolari, G., Toscani, T., \& Virgili, R. (2012). Sensory and texture properties of Italian typical dry-cured hams as related to maturation time and salt content. Meat Science, 
90, 431-437.

Benedito, J., Carcel, J.A., Clemente, G., \& Mulet, A. (2000a). Cheese maturity assessment using ultrasonics. Journal of Dairy Science, 83, 248-254.

Benedito, J., Carcel, J. A., Rossello, C., \& Mulet, A. (2001). Composition assessment of raw meat mixtures using ultrasonics. Meat Science, 57, 365-370.

Benedito, J., Carcel, J. A., Sanjuan, N., \& Mulet, A. (2000b). Use of ultrasound to assess Cheddar cheese characteristics. Ultrasonics, 38, 727-730.

Bermúdez, R., Franco, D., Carballo, J., \& Lorenzo, J. M. (2014). Physicochemical changes during manufacture and final sensory characteristics of dry-cured Celta ham. Effect of muscle type. Food Control, 43, 263-269.

Bohigas, X., Amigó, R., \& Tejada, J. (2008). Characterisation of sugar content in yoghurt by means of microwave spectroscopy. Food Research International, 41, 104-109.

Bohigas, X., \& Tejada, J. (2009). Dielectric properties of acetic acid and vinegar in the microwave frequencies range 1-20 GHz. Journal of Food Engineering, 94, 46-51.

Bourne, M. C. (2002). Texture, viscosity and food. In Food Texture and Viscosity (2nd Edition, pp. 1-32). Academic Press.

Cárcel, J. A., García-Pérez, J. V., Benedito, J., \& Mulet, A. (2012). Food process innovation through new technologies: Use of ultrasound. Journal of Food Engineering, 110, 200-207.

Chandrapala, J., Oliver, C., Kentish, S., \& Ashokkumar, M. (2012). Ultrasonics in food processing. Ultrasonics Sonochemistry, 19, 975-983.

Chemat, F., Zill-E-Huma, \& Khan, M. K. (2011). Applications of ultrasound in food technology: Processing, preservation and extraction. Ultrasonics Sonochemistry, 18, 813-835.

Cilla, I., Martínez, L., Beltrán, J. A., \& Roncalés, P. (2005). Factors affecting acceptability of drycured ham throughout extended maturation under "bodega" conditions. Meat Science, 69, 789-795.

Coll-Brasas, E., Arnau, J., Gou, P., Lorenzo, J. M., García-Pérez, J. V., \& Fulladosa, E. (2019). Effect of high pressure processing temperature on dry-cured hams with different textural characteristics. Meat Science, 152, 127-133.

Contreras, M., Benedito, J., Bon, J., \& Garcia-Perez, J. V. (2018a). Accelerated mild heating of dry-cured ham by applying power ultrasound in a liquid medium. Innovative Food Science and Emerging Technologies, 50, 94-101. 
Contreras, M., Benedito, J., Bon, J., \& Garcia-Perez, J. V. (2018b). Intensification of heat transfer during mild thermal treatment of dry-cured ham by using airborne ultrasound. Ultrasonics Sonochemistry, 41, 206-212.

Contreras, M., Benedito, J., Quiles, A., Lorenzo, J. M., Fulladosa, E., Gou, P., \& Garcia-Perez, J. V. (2020). Assessing the textural defect of pastiness in dry-cured pork ham using chemical, microstructural, textural and ultrasonic analyses. Journal of Food Engineering, 265, 109690.

Corona, E., Garcia-Perez, J. V., Gomez Alvarez-Arenas, T. E., Watson, N., Povey, M. J. W., \& Benedito, J. (2013c). Advances in the ultrasound characterization of dry-cured meat products. Journal of Food Engineering, 119, 464-470.

Corona, E., García-Pérez, J. V., Mulet, A., \& Benedito, J. (2013a). Ultrasonic assessment of textural changes in vacuum packaged sliced Iberian ham induced by high pressure treatment or cold storage. Meat Science, 95, 389-395.

Corona, E., García-Pérez, J. V., Santacatalina, J. V., Ventanas, S., \& Benedito, J. (2014). Ultrasonic characterization of pork fat crystallization during cold storage. Journal of Food Science, 79.

Corona, E., García-Pérez, J. V., Ventanas, S., \& Benedito, J. J. (2013b). Ultrasonic characterization of the fat source and composition of formulated dry-cured meat products. Food Science and Technology International, 20, 275-285.

de Prados, M., Fulladosa, E., Gou, P., Muñoz, I., Garcia-Perez, J. V., \& Benedito, J. (2015a). Non-destructive determination of fat content in green hams using ultrasound and X-rays. Meat Science, 104, 37-43.

de Prados, M., García-Pérez, J. V., \& Benedito, J. (2015b). Non-destructive salt content prediction in brined pork meat using ultrasound technology. Journal of Food Engineering, 154, 39-48.

de Prados, M., Garcia-Perez, J. V., \& Benedito, J. (2016). Ultrasonic characterization and online monitoring of pork meat dry salting process. Food Control, 60, 646-655.

de Prados, M., Garcia-Perez, J. V., \& Benedito, J. (2017). Non-invasive ultrasonic technology for continuous monitoring of pork loin and ham dry salting. Meat Science, 128, 8-14.

Delgado, A. E., Zheng, L., \& Sun, D. W. (2009). Influence of ultrasound on freezing rate of immersion-frozen apples. Food and Bioprocess Technology, 2, 263-270.

Desmond, E. (2006). Reducing salt: A challenge for the meat industry. Meat Science, $74188-$ 196. 
Dwyer, C., Mullen, A.M., Allen, P., Buckin, V. (2001). Anisotropy of ultrasonic velocity as a method of tracking postmortem ageing in beef. Proceedings 47th ICoMST, 4, 250.

Fan, K., Zhang, M., \& Mujumdar, A. S. (2017). Application of airborne ultrasound in the convective drying of fruits and vegetables: A review. Ultrasonics Sonochemistry, 39, 4757.

Fantazzini, P., Gombia, M., Schembri, P., Simoncini, N., \& Virgili, R. (2009). Use of Magnetic Resonance Imaging for monitoring Parma dry-cured ham processing. Meat Science, 82, 219-227.

Fariñas, M. D. (2016). Espectroscopía ultrasónica resonante sin contacto y su aplicación al estudio de tejidos vegetales en estructura multicapa. PhD Thesis. Universidad Politécnica de Madrid.

Font-i-furnols, M., Fulladosa, E., Prevolnik Povse, M., \& Candek-Potokar, M. (2015). Future trends in non-invasive technologies suitable for quality determinations. In M. Font-iFurnols, M. Čandek-Potokar, C. Maltin, \& M. P. Povše (Eds.), A handbook of reference methods for meat quality assessment (pp. 90-103).

Font-i-furnols, M., \& Guerrero, L. (2014). Consumer preference, behavior and perception about meat and meat products: An overview. Meat Science, 98, 361-371.

Fulladosa, E., Austrich, A., Muñoz, I., Guerrero, L., Benedito, J., Lorenzo, J. M., \& Gou, P. (2018). Texture characterization of dry-cured ham using multi energy X-ray analysis. Food Control, 89, 46-53.

Fulladosa, E., de Prados, M., García-Perez, J. V., Benedito, J., Muñoz, I., Arnau, J., \& Gou, P. (2015). X-ray absorptiometry and ultrasound technologies for non-destructive compositional analysis of dry-cured ham. Journal of Food Engineering, 155, 62-68.

Fulladosa, E., Duran-Montgé, P., Serra, X., Picouet, P., Schimmer, O., \& Gou, P. (2013). Estimation of dry-cured ham composition using dielectric time domain reflectometry. Meat Science, 93, 873-879.

Fulladosa, E., Rubio-Celorio, M., Skytte, J. L., Muñoz, I., \& Picouet, P. (2017). Laser-light backscattering response to water content and proteolysis in dry-cured ham. Food Control, $77,235-242$.

Fulladosa, E., Sala, X., Gou, P., Garriga, M., \& Arnau, J. (2012). K-lactate and high pressure effects on the safety and quality of restructured hams. Meat Science, 91, 56-61.

Fulladosa, E., Serra, X., Gou, P., \& Arnau, J. (2009). Effects of potassium lactate and high 
pressure on transglutaminase restructured dry-cured hams with reduced salt content. Meat Science, 82, 213-218.

Garau, M. C., Simal, S., Femenia, A., \& Rosselló, C. (2006). Drying of orange skin: Drying kinetics modelling and functional properties. Journal of Food Engineering, 75, 288-295.

García-Garrido, J. a, Quiles-Zafra, R., Tapiador, J., \& Luque de Castro, M. D. (2000). Activity of cathepsin B, D, H and L in Spanish dry-cured ham of normal and defective texture. Meat Science, 56, 1-6.

Garcia-Garrido, J. A., Quiles-Zafra, R., Tapiador, J., \& Luque De Castro, M. D. (1999). Sensory and analytical properties of Spanish dry-cured ham of normal and defective texture. Food Chemistry, 67, 423-427.

Garcia-Gil, N., Santos-Garcés, E., Fulladosa, E., Laverse, J., Del Nobile, M. A., \& Gou, P. (2014). High pressure induces changes in texture and microstructure of muscles in dry-cured hams. Innovative Food Science and Emerging Technologies, 22, 63-69.

Garcia-Perez, J. V., Cárcel, J. A., de la Fuente-Blanco, S., \& Riera-Franco de Sarabia, E. (2006a). Ultrasonic drying of foodstuff in a fluidized bed: Parametric study. Ultrasonics, 44, 539543.

Garcia-Perez, J. V., Cárcel, J. A., Simal, S., García-Alvarado, M. A., \& Mulet, A. (2013). Ultrasonic intensification of grape stalk convective drying: kinetic and energy efficiency. Drying Technology: An International Journal, 318, 942-950.

Garcia-Perez, J. V., de Prados, M., Martinez, G., Gomez Alvarez-Arenas, T. E., \& Benedito, J. (2019). Ultrasonic online monitoring of the ham salting process. Methods for signal analysis: Time of flight calculation. Journal of Food Engineering, 263, 87-95.

Garcia-Perez, J. V., Rosselló, C., Cárcel, J. A., De la Fuente, S., \& Mulet, A. (2006b). Effect of air temperature on convective drying assisted by high power ultrasound. Defect and Diffusion Forum, 258-260, 563-574.

García-Rey, R. M., García-Garrido, J. A., Quiles-Zafra, R., Tapiador, J., \& Luque de Castro, M. D. (2004). Relationship between $\mathrm{pH}$ before salting and dry-cured ham quality. Meat Science, $67,625-632$.

García-Rey, R. M., García-Olmo, J., De Pedro, E., Quiles-Zafra, R., \& Luque De Castro, M. D. (2005). Prediction of texture and colour of dry-cured ham by visible and near infrared spectroscopy using a fiber optic probe. Meat Science, 70, 357-363.

García-Rey, R. M., Quiles-Zafra, R., \& Luque De Castro, M. D. (2006). Relationships of genotype 
and slaughter time with the appearance and texture of dry-cured hams. Food Chemistry, 94, $271-277$.

Geesink, G. H., \& Koohmaraie, M. (1999). Effect of calpastatin on degradation of myofibrillar proteins by $\mu$-calpain under postmortem conditions. Journal of Animal Science, 77, 26852692.

Ghisalberti, L., \& Kondjoyan, A. (1999). Convective heat transfer coefficients between air flow and a short cylinder. Effect of air velocity and turbulence. Effect of body shape, dimensions and position in the flow. Journal of Food Engineering, 42, 33-44.

Gil-Sánchez, L., Garrigues, J., Garcia-Breijo, E., Grau, R., Aliño, M., Baigts, D., \& Barat, J. M. (2015). Artificial neural networks (Fuzzy ARTMAP) analysis of the data obtained with an electronic tongue applied to a ham-curing process with different salt formulations. Applied Soft Computing Journal, 30, 421-429.

Gómez Álvarez-Arenas T.E. (2004). Acoustic Impedance Matching of Piezoelectric Transducers to the Air. IEEE Trans Ultrason Ferroelectr Freq Control., 51, 624-633.

Gómez Álvarez-Arenas, T. E. (2010). Simultaneous determination of the ultrasound velocity and the thickness of solid plates from the analysis of thickness resonances using air-coupled ultrasound. Ultrasonics, 50, 104-109.

Gómez Álvarez-Arenas, T. E. (2013). Air-coupled piezoelectric transducers with active polypropylene foam matching layers. Sensors, 13, 5996-6013.

Gómez Álvarez-Arenas, T.E., Benedito, J., \& Corona, E. (2009). Non-contact ultrasonic assessment of the properties of vacuum-packaged dry-cured ham. Proceedings - IEEE Ultrasonics Symposium, 2541-2544.

Gondrexon, N., Cheze, L., Jin, Y., Legay, M., Tissot, Q., Hengl, N., Baup, S., Boldo, P., Pignon, F., \& Talansier, E. (2015). Intensification of heat and mass transfer by ultrasound: Application to heat exchangers and membrane separation processes. Ultrasonics Sonochemistry, 25, 40-50.

Gou, P., Guerrero, L., \& Arnau, J. (1995). Sex and crossbreed effects on the characteristics of dry-cured ham. Meat Science, 40, 21-31.

Gou, P., Morales, R., Serra, X., Guàrdia, M. D., \& Arnau, J. (2008). Effect of a 10-day ageing at $30{ }^{\circ} \mathrm{C}$ on the texture of dry-cured hams processed at temperatures up to $18{ }^{\circ} \mathrm{C}$ in relation to raw meat $\mathrm{pH}$ and salting time. Meat Science, 80, 1333-1339.

Grau, R., Albarracin, W., Clemente, G., \& Barat, J. M. (2007). Study of the influence of product 
and process variables in the salting and post-salting stages of PSE thawed hams. International Journal of Food Engineering, 3, 1-16.

Grau, R., Albarracín, W., Pérez, M. T., Antequera, T., \& Barat, J. M. (2011). Use of simultaneous brine thawing/salting in dry-cured Iberian ham production. Journal of Food Engineering, 104, 316-321.

Grau, R., Albarracín, W., Toldrá, F., Antequera, T., \& Barat, J. M. (2008). Study of salting and post-salting stages of fresh and thawed Iberian hams. Meat Science, 79, 677-682.

Guerrero, L, Gou, P., \& Arnau, J. (1999). The influence of meat pH on mechanical and sensory textural properties of dry-cured ham. Meat Science, 52, 267-273.

Guerrero, L., Gobantes, I., Oliver, M. À., Arnau, J., Guàrdia, M. D., Elvira, J., Riu, P., Grèbol, N., \& Monfort, J. M. (2004). Green hams electrical impedance spectroscopy (EIS) measures and pastiness prediction of dry cured hams. Meat Science, 66, 289-294.

Hamm, R. (1986). Functional properties of the myofibrillar system and their measurements. In Muscle As Food. Academic Press, Inc.

Harkouss, R., Astruc, T., Lebert, A., Gatellier, P., Loison, O., Safa, H., Portanguen, S., Parafita, E., \& Mirade, P. S. (2015). Quantitative study of the relationships among proteolysis, lipid oxidation, structure and texture throughout the dry-cured ham process. Food Chemistry, $166,522-530$.

Harkouss, R., Chevarin, C., Daudin, J. D., Sicard, J., \& Mirade, P. S. (2018). Development of a multi-physical finite element-based model that predicts water and salt transfers, proteolysis and water activity during the salting and post-salting stages of the dry-cured ham process. Journal of Food Engineering, 218, 69-79.

Håseth, T. T., Sørheim, O., Høy, M., \& Egelandsdal, B. (2012). Use of computed tomography to study raw ham properties and predict salt content and distribution during dry-cured ham production. Meat Science, 90, 858-864.

Hernández, J. A., Heyd, B., \& Trystram, G. (2008). Prediction of brightness and surface area kinetics during coffee roasting. Journal of Food Engineering, 89, 156-163.

Hii, C. L., Menon, A. S., Chiang, C. L., \& Sharif, S. (2016). Kinetics of hot air roasting of cocoa nibs and product quality. Journal of Food Process Engineering, 00, 1-6.

Holman, J. P. (1986). Heat transfer. McGraw-Hill.

ISO1841-2. (1996). Meat and meat products - Determination of chloride content. 
ISO937. (1978). Meat and meat products - Determination of nitrogen content.

Jadhav, D., B.N., R., Gogate, P. R., \& Rathod, V. K. (2009). Extraction of vanillin from vanilla pods: A comparison study of conventional soxhlet and ultrasound assisted extraction. Journal of Food Engineering, 93, 421-426.

Jayaraman, S., Pellkofer, D., Lucas, I., Bezdek, M., \& Tittmann, B. (2007). Progress in aircoupled ultrasound. Proceedings of SPIE - The International Society for Optical Engineering, 6531, 65310.

Jiménez-Colmenero, F., Ventanas, J., \& Toldrá, F. (2010). Nutritional composition of dry-cured ham and its role in a healthy diet. Meat Science, 84, 585-593.

Kang, D., Gao, X., Ge, Q., Zhou, G., \& Zhang, W. (2017). Effects of ultrasound on the beef structure and water distribution during curing through protein degradation and modification. Ultrasonics Sonochemistry, 38, 317-325.

Koch, T., Lakshmanan, S., Brand, S., Wicke, M., Raum, K., \& Mörlein, D. (2011). Ultrasound velocity and attenuation of porcine soft tissues with respect to structure and composition: I. Muscle. Meat Science, 88, 51-58.

Kragten, S. A., \& Gil, M. (2015). Instrumental tenderness - shear force. In M. Font-i-Furnols, M. Čandek-Potokar, C. Maltin, \& M. P. Povše (Eds.), A handbook of reference methods for meat quality assessment (First Edit, pp. 45-54). Cost.

Kuo, F. J., Sheng, C. T., \& Ting, C. H. (2008). Evaluation of ultrasonic propagation to measure sugar content and viscosity of reconstituted orange juice. Journal of Food Engineering, 86, 84-90.

Lacivita, V., Conte, A., Musavian, H. S., Krebs, N. H., Zambrini, V. A., \& Del Nobile, M. A. (2018). Steam-ultrasound combined treatment: A promising technology to significantly control mozzarella cheese quality. LWT - Food Science and Technology, 93, 450-455.

Larrea, V., Pérez-Munuera, I., Hernando, I., Quiles, A., Llorca, E., \& Lluch, M. A. (2007). Microstructural changes in Teruel dry-cured ham during processing. Meat Science, 76, 574582.

Leemans, V., \& Destain, M. F. (2009). Ultrasonic internal defect detection in cheese. Journal of Food Engineering, 90, 333-340.

Legay, M., Gondrexon, N., Le Person, S., Boldo, P., \& Bontemps, A. (2011). Enhancement of heat transfer by ultrasound: Review and recent advances. International Journal of Chemical Engineering, 2011, 1-17. 
Legay, M., Le Person, S., Gondrexon, N., Boldo, P., \& Bontemps, A. (2012). Performances of two heat exchangers assisted by ultrasound. Applied Thermal Engineering, 37, 60-66.

Lespinard, A. R., Bon, J., Cárcel, J. A., Benedito, J., \& Mascheroni, R. H. (2015). Effect of ultrasonic-assisted blanching on size variation, heat transfer, and quality parameters of mushrooms. Food and Bioprocess Technology, 8, 41-53.

Li, B., \& Sun, D. W. (2002). Effect of power ultrasound on freezing rate during immersion freezing of potatoes. Journal of Food Engineering, 55, 277-282.

Liu, Y., Lyon, B. G., Windham, W. R., Realini, C. E., Pringle, T. D. D., \& Duckett, S. (2003). Prediction of color, texture and sensory characteristics of beef steaks by visible and near infrared reflectance spectroscopy. A feasibility study. Meat Science, 65, 1107-1115.

Llull, P., Simal, S., Benedito, J., \& Rosselló, C. (2002). Evaluation of textural properties of a meat-based product (sobrassada) using ultrasonic techniques. Journal of Food Engineering, $53,279-285$.

López-Pedrouso, M., Pérez-Santaescolástica, C., Franco, D., Fulladosa, E., Carballo, J., Zapata, C., \& Lorenzo, J. M. (2018). Comparative proteomic profiling of myofibrillar proteins in dry-cured ham with different proteolysis indices and adhesiveness. Food Chemistry, 244, $238-245$.

Lyng, J. G., Allen, P., \& McKenna, B. M. (1997). The influence of high intensity ultrasound baths on aspects of beef tenderness. Journal of Muscle Foods, 8, 237-249.

Lyng, J. G., Allen, P., \& McKenna, B. M. (1998). The effect on aspects of beef tenderness of preand post-rigor exposure to a high intensity ultrasound probe. Journal of the Science of Food and Agriculture, 78, 308-314.

Macdonald, J. R. (1992). Impedance spectroscopy. Annals of Biomedical Engineering, 20, 289 305.

Martín, L., Córdoba, J. J., Antequera, T., Timón, M. L., \& Ventanas, J. (1998). Effects of salt and temperature on proteolysis during ripening of Iberian ham. Meat Science, 49, 145-153.

Mason, T. J., Paniwnyk, L., \& Lorimer, J. P. (1996). The uses of ultrasound in food technology. Ultrasonics Sonochemistry, 3, S253-S260.

Masselin, I., Chasseray, X., Durand-Bourlier, L., Lainé, J. M., Syzaret, P. Y., \& Lemordant, D. (2001). Effect of sonication on polymeric membranes. Journal of Membrane Science, 181, 213-220.

McClements, D. J. (1997). Ultrasonic characterization of foods and drinks: principles, methods, 
and applications. Critical Reviews in Food Science and Nutrition, 37, 1-46.

Miles, C. A., Morley, M. J., \& Rendell, M. (1999). High power ultrasonic thawing of frozen foods. Journal of Food Engineering, 39, 151-159.

Ministerio de Sanidad y Consumo de España. (2012). The NAOS Strategy. Spanish strategy for nutrition, physical activity and prevention of obesity (pp. 1-36).

Monin, G. (1998). Recent methods for predicting quality of whole meat. Meat Science, 49, 231243.

Mora, L., Fraser, P. D., \& Toldrá, F. (2013). Proteolysis follow-up in dry-cured meat products through proteomic approaches. Food Research International, 54, 1292-1297.

Morales, R., Arnau, J., Serra, X., Guerrero, L., \& Gou, P. (2008). Texture changes in dry-cured ham pieces by mild thermal treatments at the end of the drying process. Meat Science, 80 , 231-238.

Morales, R., Guerrero, L., Aguiar, A. P. S., Guàrdia, M. D., \& Gou, P. (2013). Factors affecting dry-cured ham consumer acceptability. Meat Science, 95, 652-657.

Morales, R., Guerrero, L., Serra, X., \& Gou, P. (2007a). Instrumental evaluation of defective texture in dry-cured hams. Meat Science, 76, 536-542.

Morales, R., Serra, X., Guerrero, L., \& Gou, P. (2007b). Softness in dry-cured porcine biceps femoris muscles in relation to meat quality characteristics and processing conditions. Meat Science, 77, 662-669.

Mulet, A., Benedito, J., Bon, J., \& Sanjuan, N. (1999). Review: Low intensity ultrasonics in food technology. Food Science and Technology International, 5, 285-297.

Musielak, G., Mierzwa, D., \& Kroehnke, J. (2016). Food drying enhancement by ultrasound - A review. Trends in Food Science and Technology, 56, 126-141.

Newton, K. G., \& Gill, C. O. (1981). The microbiology of DFD fresh meats: A review. Meat Science, 5, 223-232.

Niñoles, L., Clemente, G., Ventanas, S., \& Benedito, J. (2007). Quality assessment of Iberian pigs through backfat ultrasound characterization and fatty acid composition. Meat Science, 76, $102-111$.

Niñoles, L., Mulet, A., Ventanas, S., \& Benedito, J. (2011). Ultrasonic characterisation of B. femoris from Iberian pigs of different genetics and feeding systems. Meat Science, 89, 174180. 
Niñoles, L., Sanjuan, N., Ventanas, S., \& Benedito, J. (2008). Ultrasonic and sensory characterization of dry-cured ham fat from Iberian pigs with different genetics and feeding backgrounds. Meat Science, 80, 896-902.

Nowak, K. W., Markowski, M., \& Daszkiewicz, T. (2015). Ultrasonic determination of mechanical properties of meat products. Journal of Food Engineering, 147, 49-55.

Ozuna, C., Cárcel, J. A., Walde, P. M., \& Garcia-Perez, J. V. (2014). Low-temperature drying of salted cod (Gadus morhua) assisted by high power ultrasound: Kinetics and physical properties. Innovative Food Science and Emerging Technologies, 23, 146-155.

Park, K. J., Vohnikova, Z., \& Brod, F. P. R. (2002). Evaluation of drying parameters and desorption isotherms of garden mint leaves (Mentha crispa L.). Journal of Food Engineering, 51, 193-199.

Parolari, G. (1996). Review: Achievements, needs and perspectives in dry-cured ham technology: the example of Parma ham. Food Science and Technology International, 2, 69-78.

Parolari, G., Virgili, R., \& Schivazappa, C. (1994). Relationship between cathepsin B activity and compositional parameters in dry-cured hams of normal and defective texture. Meat Science, $38,117-122$.

Parreño, M., Cussó, R., Gil, M., \& Sárraga, C. (1994). Development of cathepsin B, L and H activities and cystatin-like activity during two different manufacturing processes for Spanish dry-cured ham. Food Chemistry, 49, 15-21.

Pérez-Alvarez, J. A., Fernández-López, J., Gago-Gago, M. A., Ruíz-Peluffo, C., Rosmini, M., Pagán-Moreno, M. J., López-Santoveña, F., \& Aranda-Catalá, V. (1997). Properties of drycured ham: temperature and $\mathrm{pH}$ influence during salting stage. Journal of Muscle Foods, 8 , $315-327$.

Pérez-Santaescolástica, C., Carballo, J., Fulladosa, E., Garcia-Perez, J. V., Benedito, J., \& Lorenzo, J. M. (2018a). Effect of proteolysis index level on instrumental adhesiveness, free amino acids content and volatile compounds profile of dry-cured ham. Food Research International, 107, 559-566.

Pérez-Santaescolástica, C., Carballo, J., Fulladosa, E., Garcia-Perez, J. V., Benedito, J., \& Lorenzo, J. M. (2018b). Application of temperature and ultrasound as corrective measures to decrease the adhesiveness in dry-cured ham. Influence on free amino acid and volatile compound profile. Food Research International, 114, 140-150.

Picouet, P. A., Sala, X., Garcia-Gil, N., Nolis, P., Colleo, M., Parella, T., \& Arnau, J. (2012). High pressure processing of dry-cured ham: Ultrastructural and molecular changes affecting 
sodium and water dynamics. Innovative Food Science and Emerging Technologies, 16, 335340.

Piyasena, P., Mohareb, E., \& McKellar, R. C. (2003). Inactivation of microbes using ultrasound: A review. International Journal of Food Microbiology, 87, 207-216.

Pohlman, F. W., Dikeman, M. E., Zayas, J. F., \& Unruh, J. A. (1997). Effects of Ultrasound and Convection Cooking to Different End Point Temperatures on Cooking Characteristics, Shear Force and Sensory Properties, Composition, and Microscopic Morphology of Beef Longissimus and Pectoralis Muscles. Journal of Animal Science, 75, 386-401.

Povey, M. J. W., \& Mason, T. J. (1998). Ultrasound in food processing (first edit). Springer.

Resano, H., Sanjuán, A. I., Cilla, I., Roncalés, P., \& Albisu, L. M. (2010). Sensory attributes that drive consumer acceptability of dry-cured ham and convergence with trained sensory data. Meat Science, 84, 344-351.

Rico, E., Toldrá, F., \& Flores, J. (1990). Activity of cathepsin D as affected by chemical and physical dry-curing parameters. Zeitschrift Für Lebensmittel-Untersuchung Und Forschung, 191, 20-23.

Rico, E., Toldrá, F., \& Flores, J. (1991). Effect of dry-curing process parameters on pork muscle cathepsin B, H and L activity. Zeitschrift Für Lebensmittel-Untersuchung Und-Forschung, $193,541-544$.

Riera, E., Vicente García-Pérez, J., Cárcel, J. A., Acosta, V. M., \& Gallego-Juárez, J. A. (2011). Computational study of ultrasound-assisted drying of food materials. In Innovative Food Processing Technologies: Advances in Multiphysics Simulation. John Wiley \& Sons.

Rinaldi, M., Chiavaro, E., \& Massini, R. (2010). Apparent thermal diffusivity estimation for the heat transfer modelling of pork loin under air/steam cooking treatments. International Journal of Food Science and Technology, 45, 1909-1917.

Rødbotten, R., Mevik, B. H., \& Hildrum, K. I. (2001). Prediction and classification of tenderness in beef from non-invasive diode array detected NIR spectra. Journal of Near Infrared Spectroscopy, 9, 199-210.

Rodríguez, Ó., Eim, V., Rosselló, C., Femenia, A., Cárcel, J. A., \& Simal, S. (2018). Application of power ultrasound on the convective drying of fruits and vegetables: effects on quality. Journal of the Science of Food and Agriculture, 98, 1660-1673.

Rowe, R. W. D. (1989). Electron microscopy of bovine muscle: II-The effects of heat denaturation on post rigor sarcolemma and endomysium. Meat Science, 26, 281-294. 
Rubio, M., Fullados, E., Claret, A., Guàrdia, M. D., \& Garcia-Gil, N. (2013). Detection of pastiness in dry-cured ham using dielectric time domain reflectometry. 59th International Congress of Meat Science and Technology.

Ruiz-Carrascal, J., Ventanas, J., Cava, R., Andrés, A. I., \& García, C. (2000). Texture and appearance of dry cured ham as affected by fat content and fatty acid composition. Food Research International, 33, 91-95.

Ruiz-Ramírez, J., Arnau, J., Serra, X., \& Gou, P. (2005). Relationship between water content, $\mathrm{NaCl}$ content, $\mathrm{pH}$ and texture parameters in dry-cured muscles. Meat Science, 70, 579-587.

Ruiz-Ramírez, J., Arnau, J., Serra, X., \& Gou, P. (2006a). Effect of pH24, NaCl content and proteolysis index on the relationship between water content and texture parameters in biceps femoris and semimembranosus muscles in dry-cured ham. Meat Science, 72, 185-194.

Ruiz-Ramírez, J., Serra, X., Gou, P., \& Arnau, J. (2006b). Effect of proteolysis index on texture of dry-cured ham. Archivos Latinoamericanos de Producción Animal, 14, 62-64.

Santacatalina, J. V., Contreras, M., Simal, S., Cárcel, J. A., \& Garcia-Perez, J. V. (2016a). Impact of applied ultrasonic power on the low temperature drying of apple. Ultrasonics Sonochemistry, 28, 100-109.

Santacatalina, J. V., Guerrero, M. E., Garcia-Perez, J. V., Mulet, A., \& Cárcel, J. A. (2016b). Ultrasonically assisted low-temperature drying of desalted codfish. LWT - Food Science and Technology, 65, 444-450.

Santacatalina, J. V, Soriano, J. R., \& Cárcel, J. A. (2016c). Influence of air velocity on low temperature drying of eggplant assisted by power ultrasound. Food and Bioproducts Processing, 100, 2-4.

Santos-Garcés, E., Muñoz, I., Gou, P., Sala, X., \& Fulladosa, E. (2012). Tools for studying drycured ham processing by using computed tomography. Journal of Agricultural and Food Chemistry, 60, 241-249.

Schivazappa, C., Degni, M., Nanni Costa, L., Russo, V., Buttazzoni, L., \& Virgili, R. (2002). Analysis of raw meat to predict proteolysis in Parma ham. Meat Science, 60, 77-83.

Serra, X., Ruiz-Ramírez, J., Arnau, J., \& Gou, P. (2005). Texture parameters of dry-cured ham $\mathrm{m}$. biceps femoris samples dried at different levels as a function of water activity and water content. Meat Science, 69, 249-254.

Shomer, I., Weinberg, Z. G., \& Vasiliver, R. (1987). Structural binding-properties of silvercarp (Hypophtalmichthys-molitrix) muscle affected by $\mathrm{NaCl}$ and $\mathrm{CaCl} 2$ treatments. Food 
Microstructure, 6, 199-207.

Simal, S., Benedito, J., Clemente, G., Femenia, A., \& Rosselló, C. (2003). Ultrasonic determination of the composition of a meat-based product. Journal of Food Engineering, $58,253-257$.

Singh, R. P. (1982). Thermal diffusivity in food processing. Food Technology, 36, 87-91.

Sun, Q., Zhao, X., Zhang, C., Xia, X., Sun, F., \& Kong, B. (2019). Ultrasound-assisted immersion freezing accelerates the freezing process and improves the quality of common carp (Cyprinus carpio) at different power levels. LWT - Food Science and Technology, 108, 106112.

Swatland, H. J. (2001). Elastic deformation in probe measurements on beef carcasses. Journal of Muscle Foods, 12, 97-105.

Szczesniak, A. S. (2002). Texture is a sensory property. Food Quality and Preference, 13, 215225.

Tiwari, B. K. (2015). Ultrasound: A clean, green extraction technology. TrAC - Trends in Analytical Chemistry, 71, 100-109.

Toldrá, F., \& Etherington, D. J. (1988). Examination of cathepsins B, D, H and L activities in dry-cured hams. Meat Science, 23, 1-7.

Toldrá, F., Flores, M., \& Sanz, Y. (1997). Dry-cured ham flavour: enzymatic generation and process influence. Food Chemistry, 59, 523-530.

Toozandehjani, M., Matori, K. A., Ostovan, F., Mustapha, F., Zahari, N. I., \& Oskoueian, A. (2015). On the correlation between microstructural evolution and ultrasonic properties: a review. Journal of Materials Science, 50, 2643-2665.

Tornberg, E. (2005). Effects of heat on meat proteins - Implications on structure and quality of meat products. Meat Science, 70, 493-508.

Valente, M., Prades, A., \& Laux, D. (2013). Potential use of physical measurements including ultrasound for a better mango fruit quality characterization. Journal of Food Engineering, $116,57-64$.

Venel, C., Mullen, A. M., Downey, G., \& Troy, D. J. (2001). Prediction of tenderness and other quality attributes of beef by near infrared reflectance spectroscopy between 750 and 1100 nm; further studies. Journal of Near Infrared Spectroscopy, 9, 185-198.

Ventanas, J., \& Andrés, A. I. (2001). Tecnología del jamón Ibérico: de los sistemas tradicionales 
a la explotación racional del sabor y el aroma. Mundi-Prensa.

Ventanas, J., Córdoba, J. J., Antequera, T., Garcia, C., López-Bote, C., \& Asensio, M. A. (1992). Hydrolysis and maillard reactions during ripening of Iberian ham. Journal of Food Science, $57,813-815$.

Vestergaard, C., Erbou, S. G., Thauland, T., Adler-Nissen, J., \& Berg, P. (2005). Salt distribution in dry-cured ham measured by computed tomography and image analysis. Meat Science, 69, $9-15$.

Virgili, R., Parolari, G., Schivazappa, C., Bordini, C. S., \& Borri, M. (1995). Sensory and texture quality of dry-cured ham as affected by endogenous cathepsin B activity and muscle composition. Journal of Food Science, 60, 1183-1186.

Watson, N., Hazlehurst, T., Povey, M., Vieira, J., Sundara, R., \& Sandoz, J. P. (2014). Can airborne ultrasound monitor bubble size in chocolate? Journal of Physics: Conference Series, 498, 1-13.

Watson, N., Povey, M., Corona, E., Benedito, J., \& Parker, N. (2012). Acoustic microscopy in the food industry. IOP Conference Series: Materials Science and Engineering, 42, 1-4.

Xiong, G. Y., Zhang, L. L., Zhang, W., \& Wu, J. (2012). Influence of ultrasound and proteolytic enzyme inhibitors on muscle degradation,tenderness, and cooking loss of hens during aging. Czech Journal of Food Sciences, 30, 195-205.

Yamamoto, K., Yoshida, Y., Morita, J., \& Yasui, T. (1994). Morphological and physicochemical changes in the myosin molecules induced by hydrostatic pressure. Journal of Biochemistry, $116,215-220$.

Yao, Y. (2016). Enhancement of mass transfer by ultrasound: Application to adsorbent regeneration and food drying/dehydration. Ultrasonics Sonochemistry, 31, 512-531.

Yao, Y., Wang, W., \& Yang, K. (2015). Mechanism study on the enhancement of silica gel regeneration by power ultrasound with field synergy principle and mass diffusion theory. International Journal of Heat and Mass Transfer, 90, 769-780.

You, Z., Lusk, M., Ludwig, R., \& Lord, W. (1991). Numerical simulation of ultrasonic wave propagation in anisotropic and attenuative solid materials. IEEE Transactions on Ultrasonics, Ferroelectrics, and Frequency Control, 38, 436-445.

Zhang, W., Yao, Y., \& Wang, R. (2010). Influence of ultrasonic frequency on the regeneration of silica gel by applying high-intensity ultrasound. Applied Thermal Engineering, 30, 20802087. 
Zhao, G. M., Zhou, G. H., Wang, Y. L., Xu, X. L., Huan, Y. J., \& Wu, J. Q. (2005). Time-related changes in cathepsin $\mathrm{B}$ and $\mathrm{L}$ activities during processing of Jinhua ham as a function of pH, salt and temperature. Meat Science, 70, 381-388.

Zheng, L., \& Sun, D. W. (2006). Innovative applications of power ultrasound during food freezing processes - A review. Trends in Food Science and Technology, 17, 16-23. 



\section{ANNEXED: Industrial dissemination}



Eurocarne, 284, 56-66.

\title{
El defecto de pastosidad y su caracterización no destructiva y no invasiva mediante ultrasonidos
}

\author{
Marina Contreras ${ }^{1}$, Jose Manuel Lorenzo ${ }^{2}$, Elena Fulladosa ${ }^{3}$, Amparo \\ Quiles $^{1}$, Jose Benedito ${ }^{1}$, Jose Vicente Garcia-Perez ${ }^{1}$
}

${ }^{1}$ Grupo de Análisis y Simulación de Procesos Agroalimentarios (ASPA). Departamento de Tecnología de Alimentos. Universitat Politècnica de València. Camí de Vera s/n, Valencia (46022), Spain.

${ }^{2}$ Centro Tecnológico de la Carne (CTC). Parque Tecnolóxico de Galicia. Avenida de Galicia 4, San Cibrao das Viñas (32900), Ourense, Spain.

${ }^{3}$ Institut de Recerca i Tecnologia Agroalimentàries (IRTA), Finca Camps i Armet, Monells (17121), Girona, Spain. 



\section{Texturas defectuosas, la pastosidad}

La textura es uno de los principales atributos de calidad en el jamón curado (Font-ifurnols \& Guerrero, 2014). El concepto de textura es un término complejo y que consta de diferentes sensaciones, siendo preferible hablar de propiedades texturales como un conjunto de factores en lugar de textura como un término simple. Bourne (2002) sugirió que "las propiedades texturales de un alimento constituyen un grupo de características físicas que surgen de propiedades estructurales del alimento y que se perciben por el tacto y que están relacionadas con la deformación, desintegración y flujo del alimento al someterlo a una fuerza, y que son medidas de forma objetiva por medio de funciones dependientes de la masa, tiempo y distancia". Por lo tanto, la textura es un múlti-parámetro sensorial relacionado con la estructura del jamón y que implica a diferentes sentidos en su definición. La aparición de texturas defectuosas en el jamón curado disminuye en gran medida su calidad y puede afectar negativamente a la percepción y aceptabilidad del consumidor, incluso llegando al rechazo del producto (Morales et al., 2013).

Durante la elaboración del jamón curado, el producto sufre una serie de cambios químicos y físicos que contribuyen a sus propiedades texturales finales. Los principales defectos de textura del jamón curado son el encostramiento, la textura excesivamente blanda, la pastosidad y la adhesividad. El encostramiento está caracterizado por una excesiva dureza de la superficie del jamón y ocurre generalmente durante las etapas de secado, cuando se utilizan velocidades de aire excesivamente altas o humedades relativas bajas, que incrementan el flujo externo, deshidratando de forma excesiva la superficie. La formación de esta costra superficial representa un problema importante ya que dificulta la difusión del agua del interior del jamón al ambiente, actuando como una barrera adicional a la pérdida de humedad. Las texturas excesivamente blandas, defecto conocido en lengua inglesa como "softness" y que podría traducirse como blandura, suelen estar asociadas a un mal curado y a un contenido excesivo de humedad (Resano et al., 2010). También hay otros defectos que están asociados a las texturas blandas, como es la pastosidad, que implica una pérdida de elasticidad en el jamón y la aparición de un comportamiento más viscoso, la cual se manifiesta como una sensación de recubrimiento en boca similar a la que provoca una mezcla de agua y harina durante la masticación. Además de estar asociada a una textura excesivamente blanda, la pastosidad en jamón se caracteriza por presentar un tacto aceitoso (Parolari, et al., 1994), mayor brillo al corte (Arnau et al., 1998), sabor ligeramente amargo y picante y falta del aroma típico a jamón (García-Rey et al., 2004). Asimismo, los jamones pastosos son más sensibles a desarrollar cristales de tirosina y velo blanco. La pastosidad no implica únicamente una pérdida de calidad significativa, que puede conllevar un rechazo y depreciación del jamón defectuoso por parte del consumidor, sino que también dificulta el loncheado, disminuyendo el rendimiento e induce el defecto de adhesividad. El problema de la adhesividad ocurre tanto entre las lonchas como entre loncha y separador plástico. 
El defecto de pastosidad está causado por una excesiva actividad proteolítica, que conlleva una intensa degradación de la estructura proteica. Existen múltiples factores que influyen tanto en la aparición, como en la intensidad de este defecto y éstos pueden clasificarse en factores tecnológicos, relacionados con el proceso de elaboración, y factores endógenos, inherentes a las características del jamón fresco (Guerrero et al., 1999):

- Factores tecnológicos:

- Contenido en sal. La sal contribuye a la desnaturalización proteica afectando a la liberación de péptidos y aminoácidos que participan en la formación de los compuestos aromáticos y la textura propia del jamón curado (Martín et al., 1998). Además, la sal inhibe la actividad de las catepsinas, calpaínas y proteasomas, principales enzimas responsables de las texturas blandas (Toldrá \& Flores, 1998). Muchos estudios han puesto de manifiesto la elevada relevancia de este factor en el desarrollo de la pastosidad (Arnau et al., 1998; Ruiz-Ramírez et al., 2006a; RuizRamírez et al., 2006b). Así, las nuevas tendencias que buscan la reducción del contenido de sal en los jamones, están ocasionando un aumento de la incidencia de este defecto.

- Temperatura de proceso. Con el objetivo de acortar el proceso de elaboración y así disminuir los costes industriales, se está haciendo más frecuente el aumento de la temperatura en el reposo y durante las primeras etapas de secado. Este incremento de la temperatura, si el contenido en sal no es suficiente en las partes más internas del jamón, puede provocar una elevada acción proteolítica, favoreciendo la aparición del defecto de pastosidad (Arnau et al., 1997).

- Factores endógenos:

- Tipo de músculo. Tanto la grasa subcutánea como la corteza del jamón suponen unas barreras naturales a la penetración de la sal durante el salado. Esto hace que la difusión de la sal transcurra desde la cara opuesta a la corteza, donde se sitúa el músculo Semimenbranosus (SM), hasta las zonas internas. Así, la sal tarda más tiempo en alcanzar los músculos más cercanos a la grasa subcutánea, como es el Biceps femoris $(B F)$, siendo estos los que por tanto tienen una mayor probabilidad de presentar el defecto de pastosidad (García-Rey et al., 2005).

- Tamaño del jamón. Es necesario recalcar que los jamones de mayor tamaño no necesitan únicamente más tiempo de salado para absorber más sal, sino que también el tiempo de difusión de la sal durante el postsalado debe ser mayor. Por lo tanto, el peso del jamón no debe tenerse en cuenta únicamente en el tiempo de salado sino también en el de reposo y secado para evitar el desarrollo de texturas anómalas (Parolari, 1996). 
- $\quad \boldsymbol{p H}$. Diferentes estudios han puesto de manifiesto que un $\mathrm{pH}$ inicial de la muestra fresca fuera del rango estándar (5.8-6.2) influye negativamente en la textura final del jamón (Arnau et al., 1998; Ruiz-Ramírez et al., 2005; Ruiz-Ramírez et al., 2006a).

La caracterización de texturas defectuosas y el ensayo de medidas correctoras de las mismas, fueron los principales objetivos que se persiguieron en el marco del proyecto de investigación RTA2013-00030-C03, realizado entre el IRTA (coordinador del proyecto), el Centro de Tecnología de la Carne de Galicia y la Universitat Politècnica de València. Para ello se contó con un lote de 200 jamones de cerdo blanco, que fue sometido a un proceso de elaboración particular, en el que se trató de inducir diferentes niveles de pastosidad, en un amplio rango de contenidos de sal. Es decir, se forzó la aparición a diferentes intensidades del defecto, en jamones con bajo y alto contenido de sal, intentado independizar la relación inherente entre pastosidad y contenido en sal. Este artículo se centra únicamente en los resultados obtenidos en la caracterización de dicho defecto, en una primera parte utilizando técnicas convencionales de análisis y en una segunda parte, mediante el uso de ultrasonidos de baja intensidad. Los estudios se focalizaron en el músculo $B F$ al considerarse el más sensible a la aparición de la pastosidad. A continuación, se muestran algunos de los principales resultados obtenidos en este proyecto.

\section{Caracterización del defecto de pastosidad mediante ensayos destructivos}

El análisis sensorial es la principal alternativa existente en la actualidad para caracterizar el defecto de pastosidad, por lo tanto, las distintas alternativas deben de tomar ésta como referencia. En el proyecto RTA2013-00030-C03, el defecto de pastosidad fue caracterizado sensorialmente por un panel de catadores entrenados (IRTA), que puntuaron la pastosidad entre 0 (sin pastosidad) y 6 (máxima pastosidad). Así, los jamones se agruparon en lotes de baja $(<1)$, media (1-2.5) y alta pastosidad (>2.5), de acuerdo a la puntuación del panel. Tal y como se ha comentado con anterioridad, el defecto de pastosidad está caracterizado por una elevada acción proteolítica. Por este motivo, es de esperar que la medida de pastosidad sensorial tenga una buena relación con el índice de proteólisis. Los resultados obtenidos en el proyecto se muestran en la Figura 1 (Contreras et al., 2020) donde se aprecia que la correlación entre ambas variables es significativa $(\mathrm{p}<0.05)$, incrementándose el índice de proteólisis a medida que aumenta la pastosidad, sin embargo, se observó una elevada variabilidad experimental. Este hecho fue especialmente evidente en los jamones sin defecto de pastosidad (0), que presentaron índices de proteólisis entre 28 y $37 \%$. Estos resultados ponen de manifiesto que la proteólisis, directamente asociada al defecto de pastosidad, podría considerarse como muy específica, pudiendo quedar enmascarada en términos absolutos por la provocada por la sal. En este sentido, López-Pedrouso et al. (2018) pusieron de manifiesto que existen algunas proteínas, como la miosina-1, $\alpha$-actina y miosina-4, que pueden considerarse biomarcadores del índice de proteólisis. Sin embargo, este 
trabajo no se centró específicamente en la pastosidad sensorial, si no en el índice de proteólisis, lo que no permitió identificar los biomarcadores de este defecto.

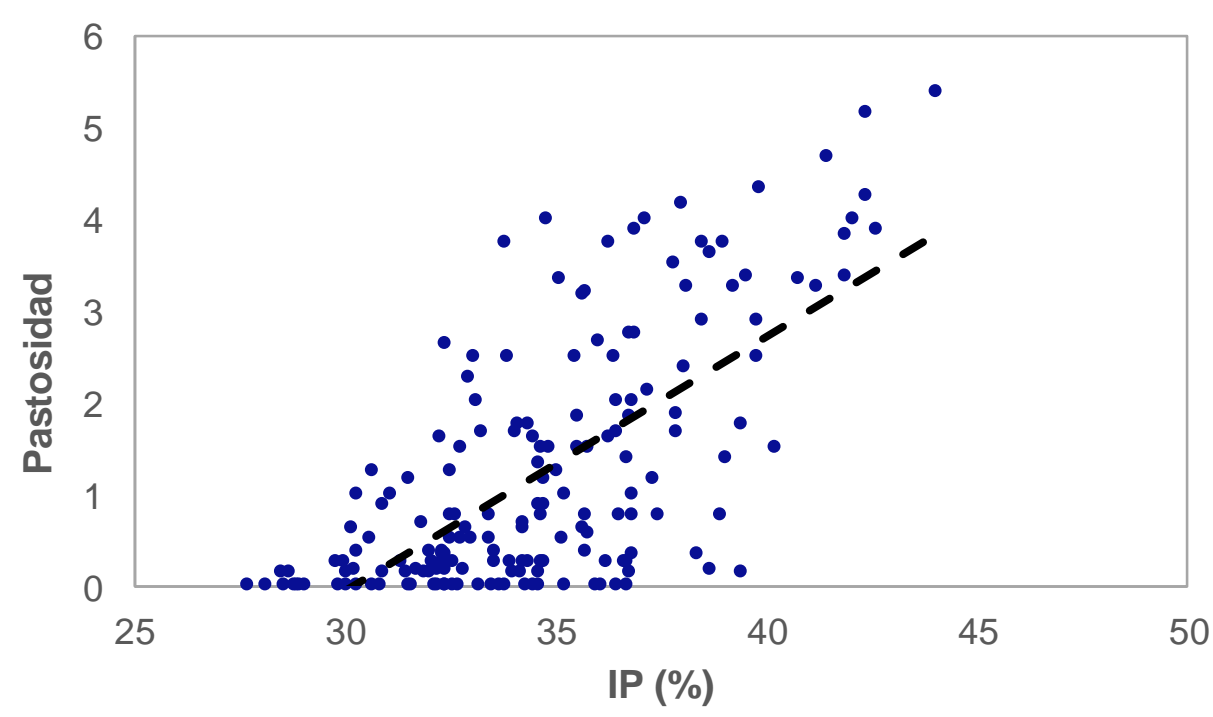

Figura 1. Influencia del índice de proteólisis en la pastosidad sensorial de jamón curado. Se considera baja $<1$, media 1-2.5, alta pastosidad $>2.5$ (Contreras et al., 2020).

Los cambios sufridos en el jamón por procesos proteolíticos y de otra índole, que dan lugar al defecto de pastosidad, pueden acabar afectando la estructura muscular del jamón. Para verificar este aspecto, en el proyecto RTA2013-00030-C03, se realizó un estudio microestructural de los jamones elaborados. En la Figura 2 se muestran imágenes de la micro y ultraestructura de jamón con elevada pastosidad. La pastosidad provoca una manifiesta degradación de la integridad estructural. En muchas partes, la membrana sarcolema, el perimisio y el tejido conectivo están rotos (Figura 2A y 2B) e incluso no se aprecian, despareciendo la separación entre las células musculares y formándose espacios intercelulares (Figura 2C) en los que se acumulan solutos intracelulares. A nivel ultraestructural, en las muestras con elevada pastosidad, los discos Z, la Zona-H y las estructuras de los costámeros desaparecen en muchas zonas (Figura 2C), evidenciando la severa degradación de la estructura proteica (Contreras et al., 2020). 

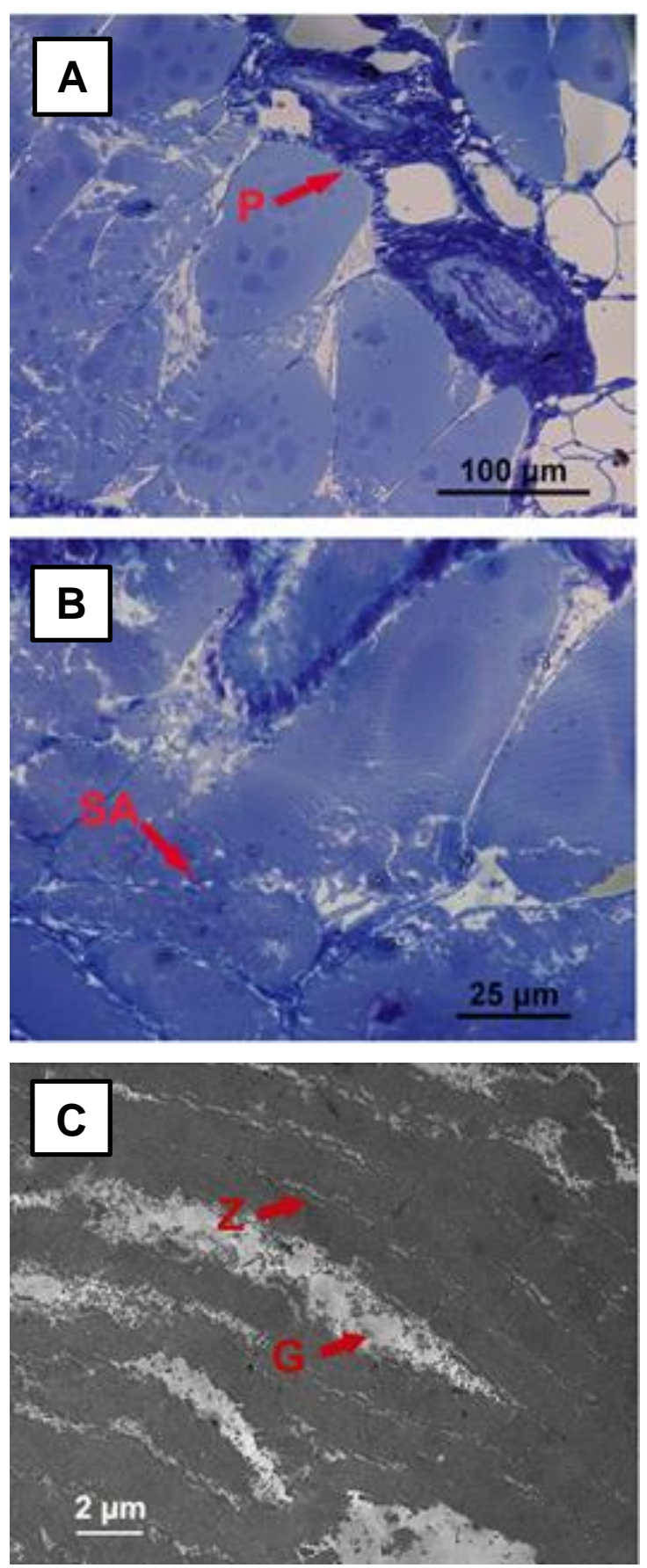

Figura 2. Microscopía óptica (A-B) y microscopía electrónica de transmisión (C) de Biceps femoris altamente pastoso (20x: A; 60x: B; 1200x: C). G: Espacio intercelular; P: Perimisio; S: Sarcómero; SA: Sarcolema; Z: Línea-Z (Contreras et al., 2020).

La caracterización instrumental de la textura también arrojó información acerca del defecto de pastosidad (Contreras et al., 2020). Así, el incremento de la pastosidad conllevó un descenso de la dureza del jamón (Figura 3A) y un incremento de su capacidad de relajación (Figura 3B) (Contreras et al., 2020), este último asociado a un comportamiento menos elástico. Estos resultados evidenciaron que las muestras de alta pastosidad son también excesivamente blandas (Figura 3A), lo que estaría asociado a un menor módulo elástico. Sin embargo, al igual que 
sucedía con el índice de proteólisis, se encontró una elevada variabilidad experimental, por lo que también existen muestras sin defecto de pastosidad que son excesivamente blandas. Por lo tanto, la medida instrumental de dureza no es suficiente para poder caracterizar el defecto de pastosidad. En cuanto a la capacidad de relajación, que podría definirse como la capacidad de la muestra de recuperar su posición cuando es deformada, se observó el mismo comportamiento, es decir, se incrementa este parámetro con la pastosidad sensorial (Figura 3B), pero siguen existiendo jamones sin defecto de pastosidad con elevada capacidad de relajación. Estos resultados demuestran que el desarrollo de la textura depende de varios factores y no solamente del índice de proteólisis, poniendo de manifiesto la gran complejidad de este defecto.
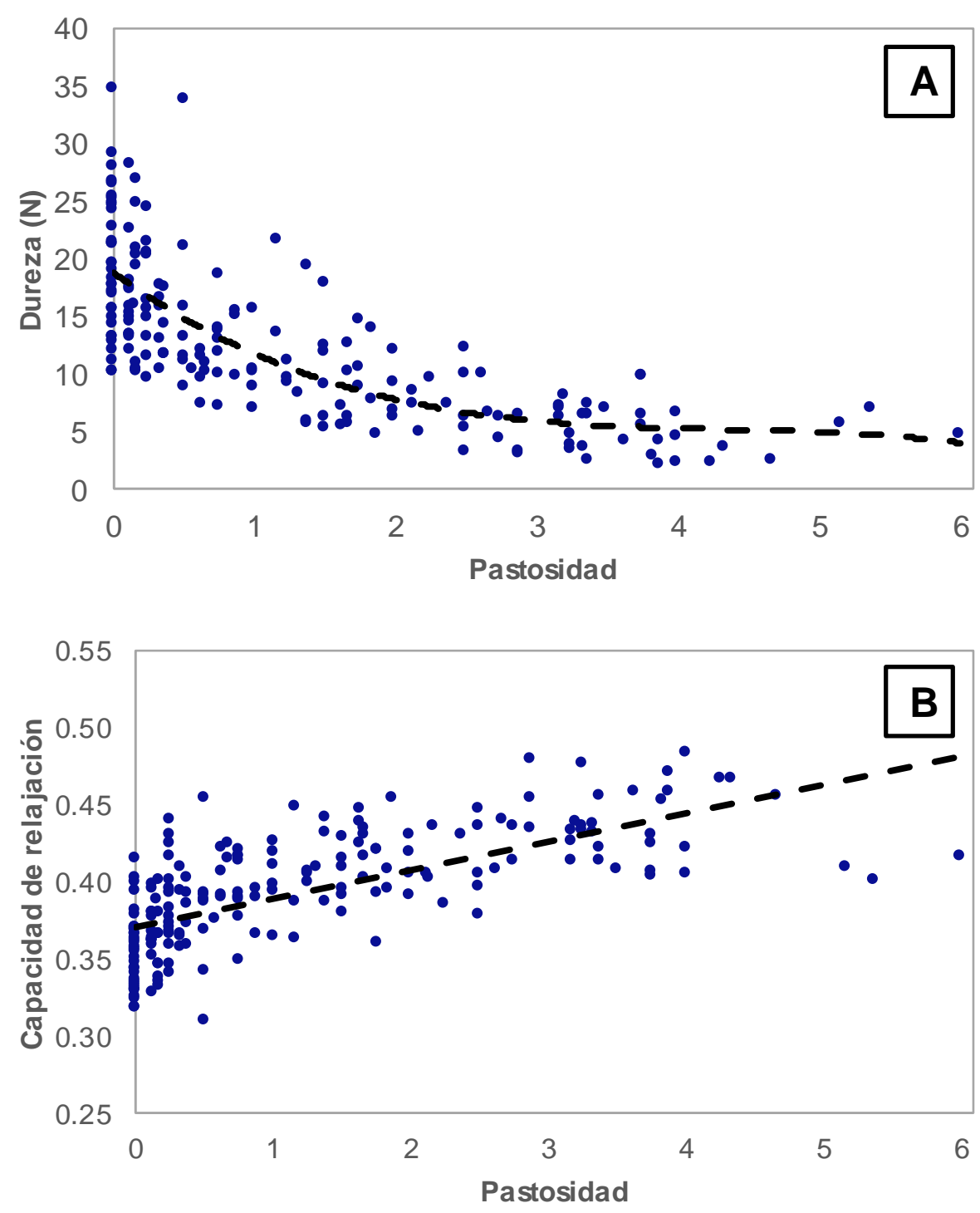

Figura 3. Influencia de la pastosidad en los parámetros texturales de dureza (A) y capacidad de relajación (B). Se considera baja <1, media 1-2.5, alta pastosidad $>2.5$ (Contreras et al., 2020). 


\section{Ultrasonidos de baja intensidad para el control de calidad no destructivo y no invasivo. Fundamentos y aplicaciones en jamón curado}

Actualmente, existen multitud de opciones industriales para caracterizar las propiedades externas de los alimentos (dimensiones, color, etc...), sin embargo, las opciones disponibles para la caracterización de las propiedades internas de los alimentos de forma no destructiva, son mucho más limitadas. Las tecnologías actuales de análisis no destructivo que se emplean en la industria alimentaria pueden clasificarse en dos grupos. En primer lugar, las tecnologías basadas en la radiación electromagnética, a sus diferentes longitudes de onda, tales como los rayos X, radiación infrarroja (NIR, FIR), microondas y resonancia magnética nuclear, ampliamente desarrolladas en el entorno médico. Aunque no es posible generalizar, ya que las propiedades de las distintas técnicas son dependientes de la longitud de onda, el uso de la radiación electromagnética está más extendido a escala de laboratorio para caracterizar analíticamente propiedades como la grasa o la humedad que para su aplicación en entornos industriales para inspeccionar propiedades internas de piezas enteras. Este hecho es debido a que presentan una baja capacidad de penetración en los materiales a intensidades bajas. Existen multitud de trabajos que han utilizado estas tecnologías para la caracterización de la composición o textura de productos cárnicos. En este sentido, Fulladosa et al. (2015) utilizaron Rayos -X para la estimación del contenido en sal y grasa de jamones enteros, obteniéndose buenos resultados. Del mismo modo, este grupo de autores también utilizó esta tecnología para estimar los cambios texturales provocados por la adición de enzimas proteolíticas en jamón curado loncheado mediante Rayos -X (Fulladosa et al., 2018). La inducción electromagnética es otra tecnología que también se está utilizando a nivel industrial para la caracterización de los contenidos de sal y grasa en jamones enteros (Schivazappa et al., 2017). El coste del desarrollo e implementación de estas tecnologías también han limitado sus usos posteriores, a diferencia de lo que ocurre en aplicaciones médicas. En este contexto, la segunda tecnología viable para la caracterización no destructiva de alimentos son los ultrasonidos de baja intensidad, ondas acústicas con frecuencias superiores a $20 \mathrm{kHz}$. Los ultrasonidos constituyen una alternativa rápida, precisa, de bajo coste y simple (McClements, 1997) y que permite obtener información del interior de los materiales, por su elevada capacidad de penetración, incluso a bajas intensidades. La interacción de las ondas acústicas con la materia modifica tanto su velocidad como su energía y esto puede proporcionar información muy relevante de la composición, estructura y estado físico de los alimentos (Awad et al., 2012). Así, los dos principales parámetros que se pueden obtener de las medidas ultrasónicas son la velocidad y la atenuación. La velocidad ultrasónica es un parámetro sencillo de medir ya que se calcula mediante el cociente entre el espesor de la muestra (distancia que recorre la onda) y el tiempo de vuelo (tiempo que necesita la onda para atravesar la muestra) (de Prados et al., 2016; GarciaPerez et al., 2019). La velocidad depende de las propiedades elásticas y densidad del medio, presentando valores de aproximadamente $340 \mathrm{~m} / \mathrm{s}$ en aire, $1490 \mathrm{~m} / \mathrm{s}$ en agua y de $5560 \mathrm{~m} / \mathrm{s}$ en 
acero inoxidable (American Society for Non Destructive Testing). Así, la velocidad ultrasónica es dependiente del contenido en agua y sólidos de los alimentos y muy sensible a la presencia de aire. En jamón fresco, la medida de la velocidad, en condiciones de refrigeración, se puede utilizar para determinar el contenido en grasa, puesto que al aumentar el ratio grasa-agua, aumenta la velocidad ultrasónica (Figura 4A) (de Prados et al., 2015a).
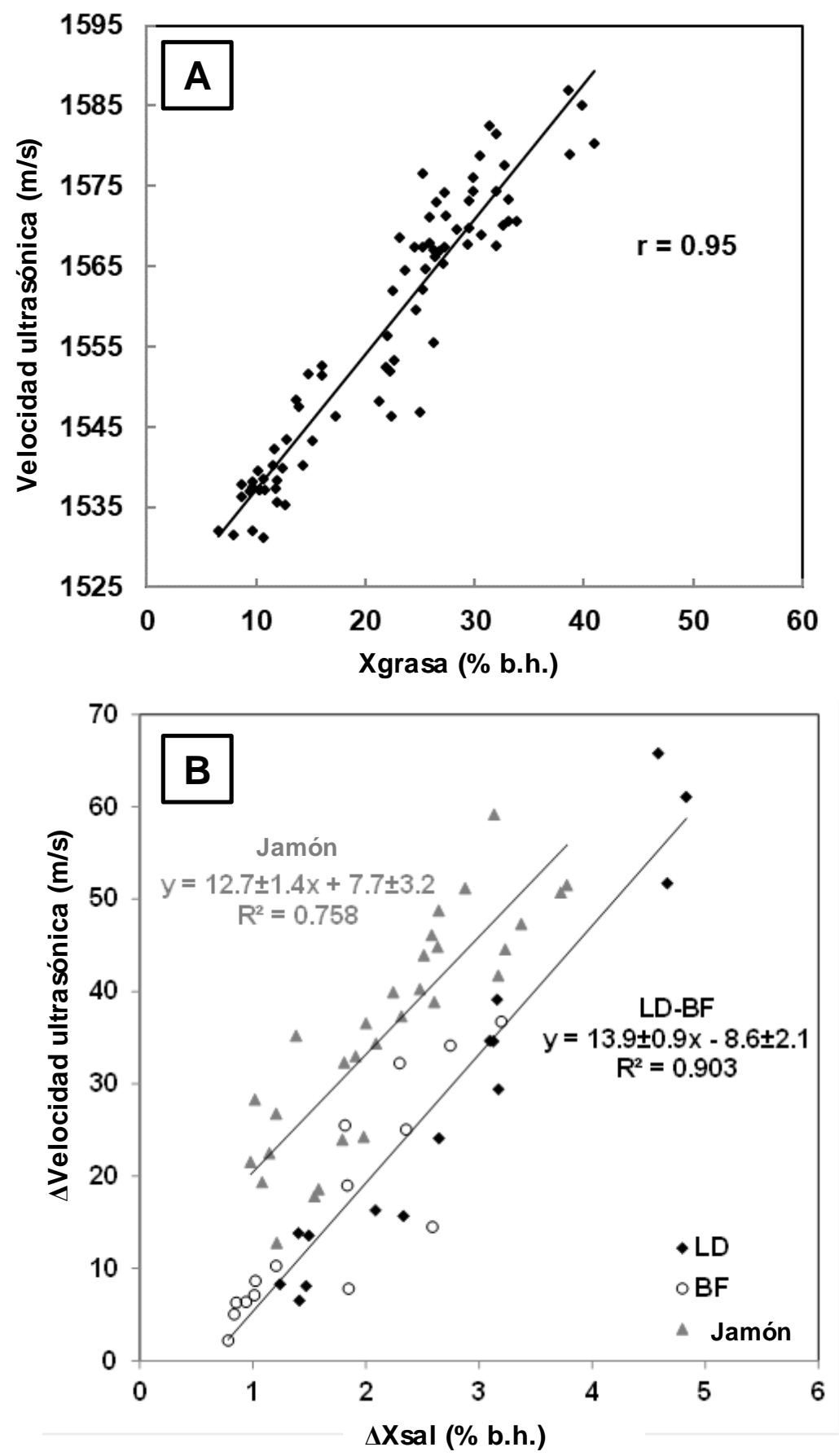

Figura 4. A. Influencia del contenido en grasa de jamón fresco en la velocidad ultrasónica $\left(4^{\circ} \mathrm{C}\right)(\mathrm{de}$ Prados et al., 2015a). B. Relación entre la ganancia en sal y el cambio de la velocidad ultrasónica durante el salado de jamón entero y músculos individuales (Biceps femoris y Longisimus dorsi) (de Prados et al., 2015b). 
Durante el salado del jamón, la salida de agua y ganancia en sal, provoca un aumento del contenido de sólidos, lo que conlleva un incremento de la velocidad ultrasónica. Así, midiendo la velocidad ultrasónica en el jamón antes y después del salado, se puede estimar de forma muy precisa la ganancia en sal (Figura 4B). Esta tecnología, también se puede utilizar para monitorizar a tiempo real el proceso de salado y conocer en todo momento cuanta sal ha ganado una pieza de jamón (Figura 5) (de Prados et al., 2015b).

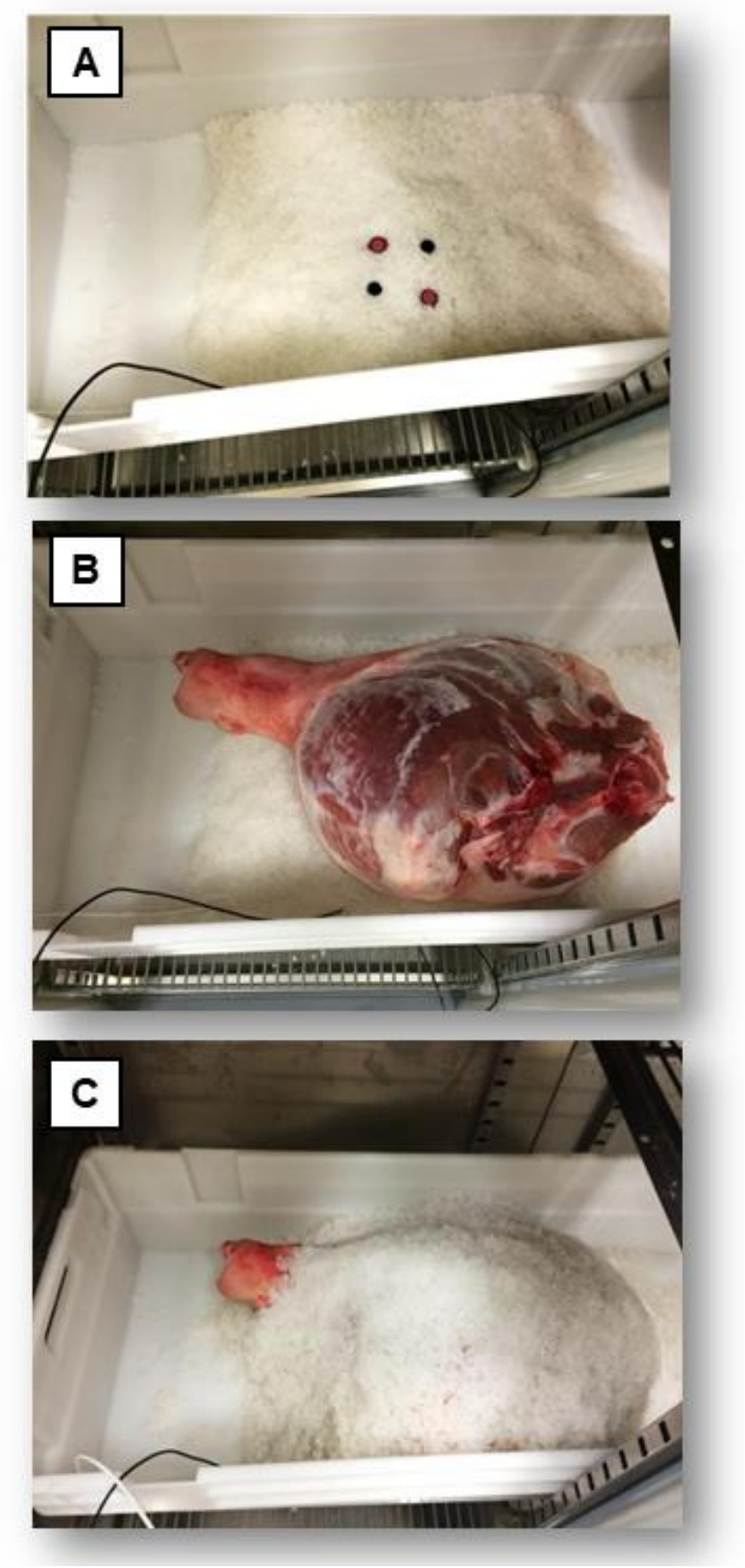

Figura 5. Procedimiento experimental para la monitorización a tiempo real del proceso de salado de jamón entero mediante medidas ultrasónicas en pulso-eco (de Prados et al., 2016). A. Colocación de capa de sal en la base de la cubeta rodeando los transductores ultrasónicos, B. Colocación del jamón sobre la capa de sal y los transductores, $C$. Recubrimiento del jamón con capa de sal. 
La medida de la velocidad ultrasónica se utilizó en el proyecto RTA2013-00030-C03 para monitorizar la evolución de los jamones durante las distintas etapas del proceso de elaboración: salado, reposo y secado (Figura 6). Se observa un incremento de la variación de velocidad, respecto a la del jamón fresco, como consecuencia principalmente de la ganancia en sal (fase de salado) y pérdida de humedad (fases de salado, reposo y secado), y también de los cambios texturales asociados. Posteriormente, en estos mismos jamones y una vez loncheados, la medida de la velocidad ultrasónica contribuyó a caracterizar su contenido final de humedad (Figura 7A) y sal (Figura 7B). En este sentido, Villamiel et al. (2017) presentaron una recopilación de trabajos que utilizan la velocidad ultrasónica para la caracterización de productos cárnicos crudo-curados.

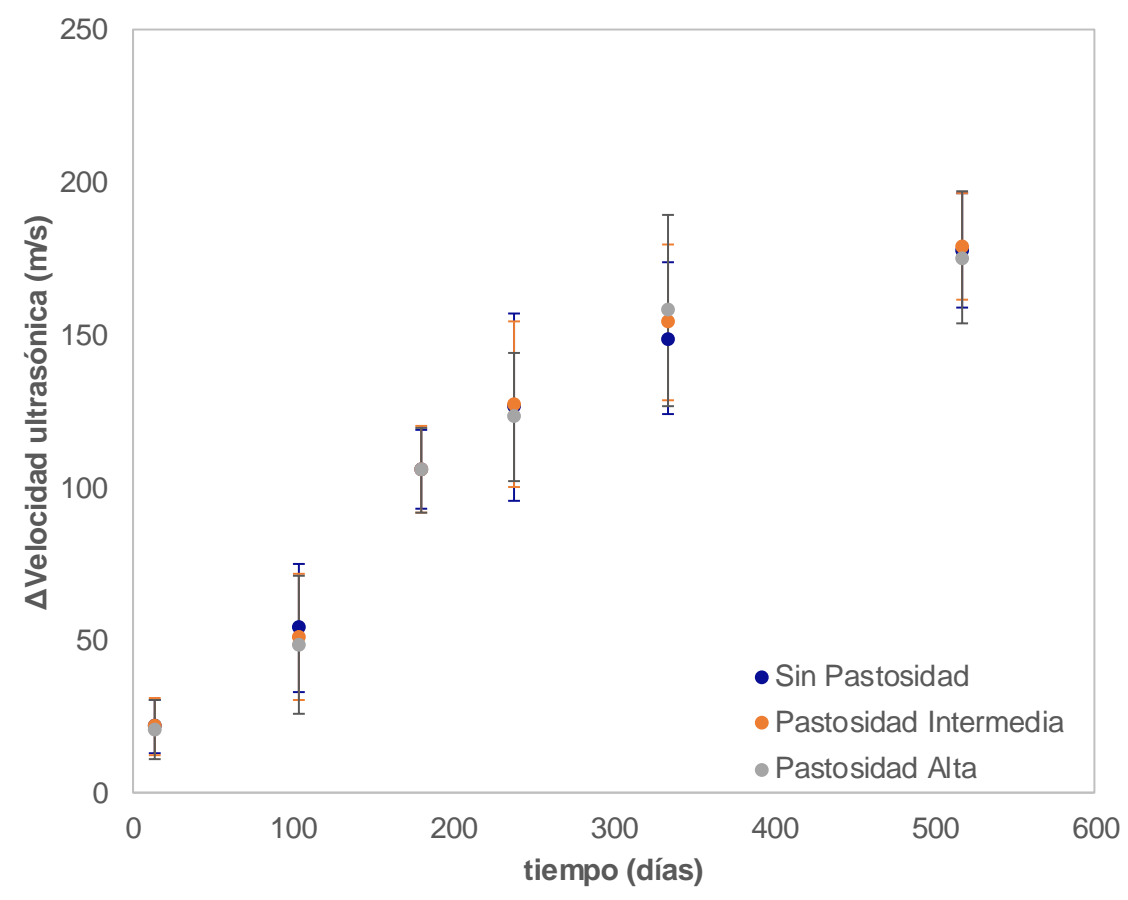

Figura 6. Evolución de la variación de la velocidad ultrasónica ( $\Delta V=$ Velocidad - Velocidad en el jamón fresco) durante el proceso de elaboración de jamón curado $(\mathrm{n}=200)$. Se han clasificado los jamones de acuerdo a su nivel de pastosidad medido sensorialmente en el producto terminado. Se considera sin pastosidad $<$, pastosidad intermedia 1-2.5 y alta pastosidad $>2.5$.

La atenuación ultrasónica es una medida de la pérdida de energía que experimenta la onda ultrasónica cuando atraviesa un medio material. Esa pérdida de energía se debe a dos principales mecanismos: absorción y dispersión. La absorción representa la fracción de energía necesaria para deformar el material elástico mientras que la dispersión representa las pérdidas relacionadas con el cambio de dirección de la onda debido a reflexiones y refracciones. La componente de absorción se incrementa en materiales viscosos al incrementarse la energía cedida a partículas adyacentes (Nowak et al., 2015). Así, la atenuación es mayor en materiales viscoelásticos (como sería el jamón curado) que en elásticos, y es mayor en gases que en sólidos y líquidos, y se incrementa con la frecuencia de la onda ultrasónica, ya que para atravesar una misma distancia se 
necesitan más ciclos. La medida de atenuación es muy compleja en materiales sólidos, debido a que presenta una baja precisión por la dificultad de estimar la energía perdida en la superficie del material. Generalmente, se cuantifica a partir del coeficiente de atenuación que se mide a partir de los cambios de amplitud que experimenta la señal ultrasónica al modificarse el espesor de la muestra (Koch et al., 2011; Nowak et al., 2015). Debido a alta complejidad de la medida experimental, y su escaso uso previo en alimentos sólidos con superficie irregular y elevado espesor, no se planteó la medida de la atenuación para la monitorización del proceso de elaboración de los jamones del proyecto RTA2013-00030-C03, pero sí que se utilizó una vez los jamones fueron loncheados.
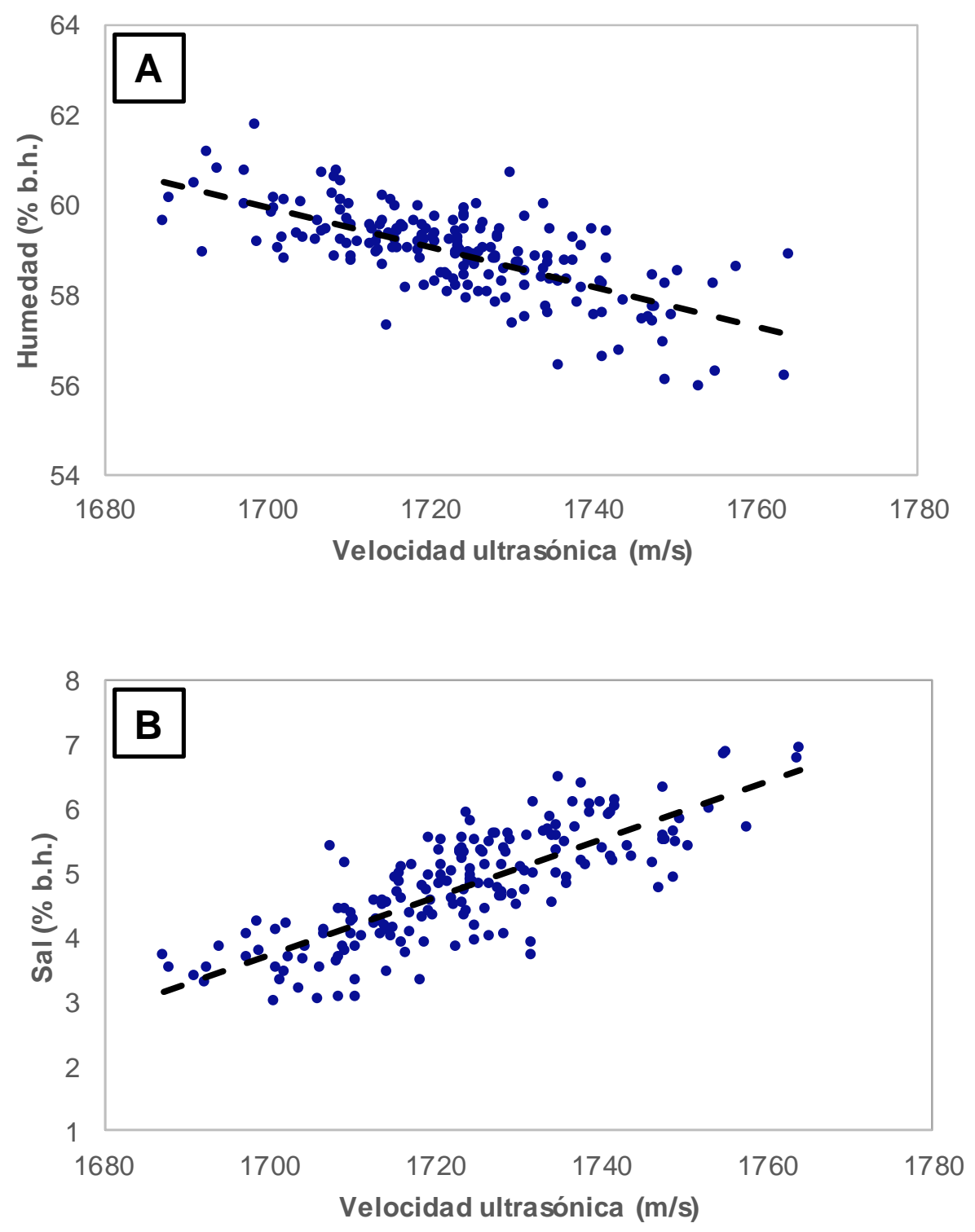

Figura 7. Influencia del contenido en humedad (A) y sal (B) en la velocidad ultrasónica en músculo Biceps femoris de jamón curado (Contreras et al., 2020). 
Las técnicas ultrasónicas convencionales requieren de contacto entre los transductores (Figuras 8A y 8B) y la superficie de los alimentos utilizando medios de acople (agua, aceite o geles), lo que puede generar problemas durante su aplicación (daños en superficie por exceso de presión contra el alimento o riesgo de contaminación cruzada) y dificulta su instalación en líneas industriales. Así, las técnicas ultrasónicas convencionales deben catalogarse como nodestructivas, pero mínimamente invasivas. La alternativa es la utilización de técnicas sin contacto en las que el acople entre transductor y muestra se realiza a través del aire (Figuras 8C y 8D). Estas técnicas presentan múltiples ventajas tales como:

- Se evita el uso de partes móviles para el acoplamiento de los transductores a la superficie del alimento, lo que reduce en gran medida el coste de equipamiento e implica velocidades de inspección más altas.

- No existe ningún tipo de contaminación o daño en la superficie del alimento.

- La muestra no se comprime durante la medida, lo que mejora la precisión.

- La obtención de imágenes ultrasónicas es factible y fiable y se puede realizar a elevada velocidad.
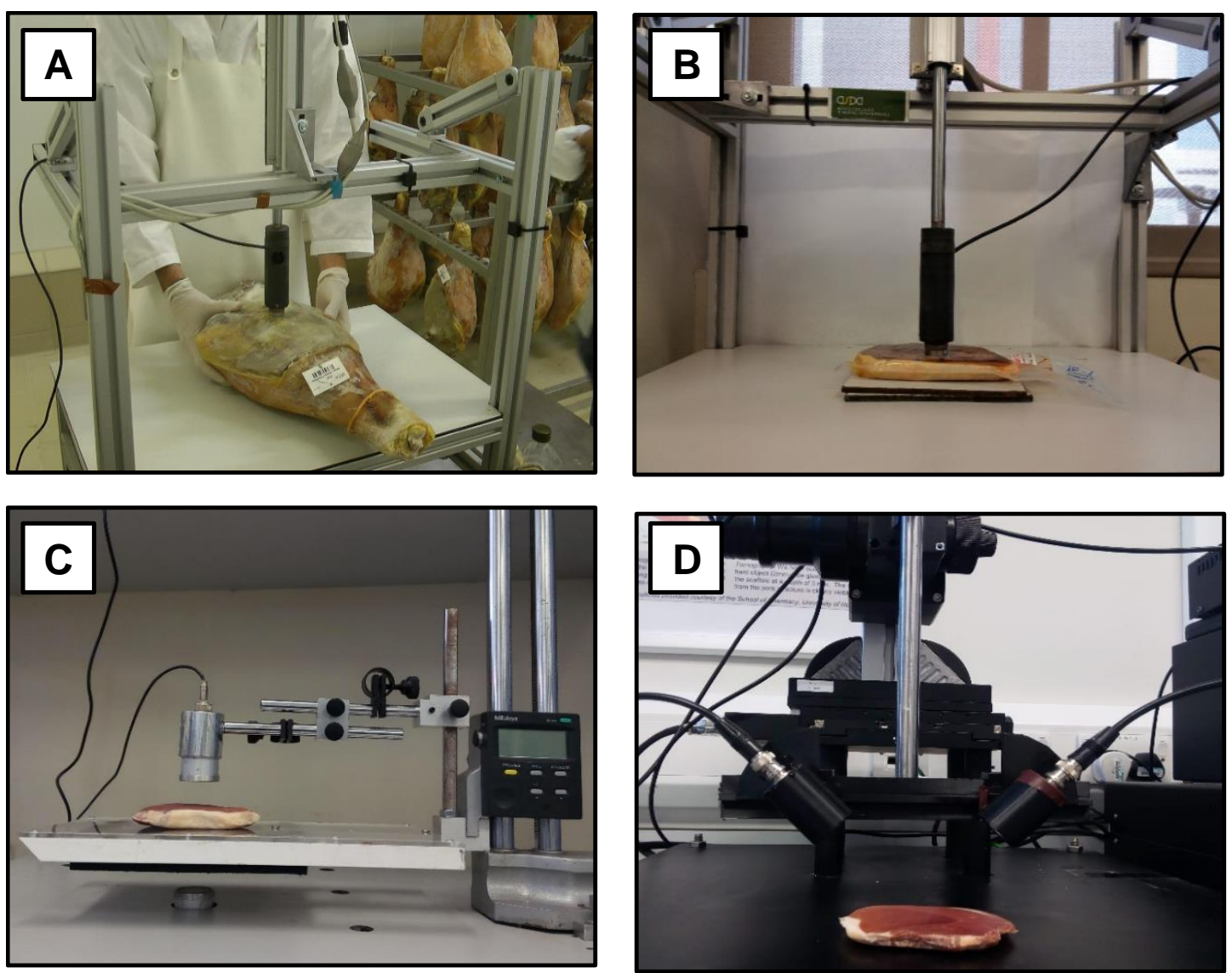

Figura 8. Medidas ultrasónicas en jamón curado: mediante contacto, en piezas enteras (A) y lonchas (B); sin contacto en lonchas mediante incidencia normal (C) y oblicua (D). Imagen cedida por Marina Contreras e incluida en su Tesis Doctoral. 
A pesar de presentar multitud de ventajas, el desarrollo de la tecnología ultrasónica sin contacto se ha visto obstaculizado por la dificultad de conseguir una transmisión eficiente de la onda acústica desde el transductor piezoeléctrico hasta la muestra, a través del aire, que es un medio muy atenuante y con propiedades acústicas muy diferentes al transductor y los alimentos analizados. Los estudios previos que se encuentran en bibliografía para caracterización de alimentos obtuvieron resultados poco satisfactorios (Cho \& Irudayaraj, 2003; Gan et al., 2006; Saggin \& Coupland, 2001; Watson et al., 2014), lo que se puede atribuir al tipo de transductores de baja eficiencia utilizados en ese momento. En este sentido, el Grupo ASPA de la Universitat Politècnica de València ha sido pionero en el uso de transductores piezoeléctricos de alta eficiencia (Gómez Álvarez-Arenas, 2013; Gómez Álvarez-Arenas, 2004), que permiten una caracterización satisfactoria y totalmente no invasiva de alimentos. Así, se han realizado medidas ultrasónicas acopladas por aire en jamón envasado y la precisión conseguida en medidas de velocidad es comparable a las técnicas ultrasónicas convencionales con contacto (Corona et al., 2013). Recientemente, este grupo ha utilizado esta tecnología con éxito, para la caracterización no invasiva de productos de estructura y origen muy diferente, como aguacate (Sánchez-Torres et al., 2019) y hamburguesa de cerdo (Fariñas et al., 2019). Por la tanto, el desarrollo de las técnicas ultrasónicas sin contacto constituye un área muy poco explorada científica y tecnológicamente y de enorme interés en aplicaciones en productos cárnicos.

\section{Caracterización de pastosidad en jamón curado mediante ultrasonidos}

Con el objetivo de analizar la viabilidad del uso de la velocidad ultrasónica para estimar las propiedades texturales del jamón curado y caracterizar el defecto de pastosidad, y de cara a adoptar la metodología más adecuada para el desarrollo del proyecto RTA2013-00030-C03, se realizó un estudio previo con jamón curado comercial loncheado $(1 \mathrm{~cm})$ llevando a cabo medidas ultrasónicas por contacto en dos músculos, Biceps femoris y Longissimus dorsi. Los resultados mostraron que la velocidad ultrasónica se incrementa de forma significativa con la dureza de la muestra, discriminándose bien las muestras de los dos músculos (Figura 9A). Por lo tanto, esta medida se puede utilizar para la caracterización de muestras defectuosas con textura excesivamente blanda. En cuanto a la capacidad de relajación, un aumento de este parámetro conllevó un descenso de la velocidad de propagación ultrasónica (Figura 9B), probablemente asociado a la pérdida de propiedades elásticas. Por lo tanto, para el desarrollo del proyecto RTA2013-00030-C03 se consideró que, potencialmente, la velocidad ultrasónica podría permitir caracterizar el defecto de pastosidad debido a su relación con propiedades texturales como la dureza y capacidad de relajación. Por el contrario, en los resultados obtenidos en el proyecto no se observó ninguna relación entre la velocidad ultrasónica y la pastosidad, ni en el caso de los jamones enteros (Figura 6), ni en lonchas (Contreras et al., 2020). Estos resultados podrían explicarse considerándose la forma en la que se elaboraron los jamones, en los que se forzó 
independizar el defecto de pastosidad del contenido de sal, de forma que no existieran diferencias en cuanto al contenido de humedad y sal para los grupos de baja, media y alta pastosidad. Este hecho pudo disminuir la capacidad discriminativa de este parámetro, en este sentido, su utilización en jamón comercial con defecto de pastosidad, donde la intensidad del defecto estaría asociada a un menor contenido en sal, podría mejorar los resultados obtenidos.
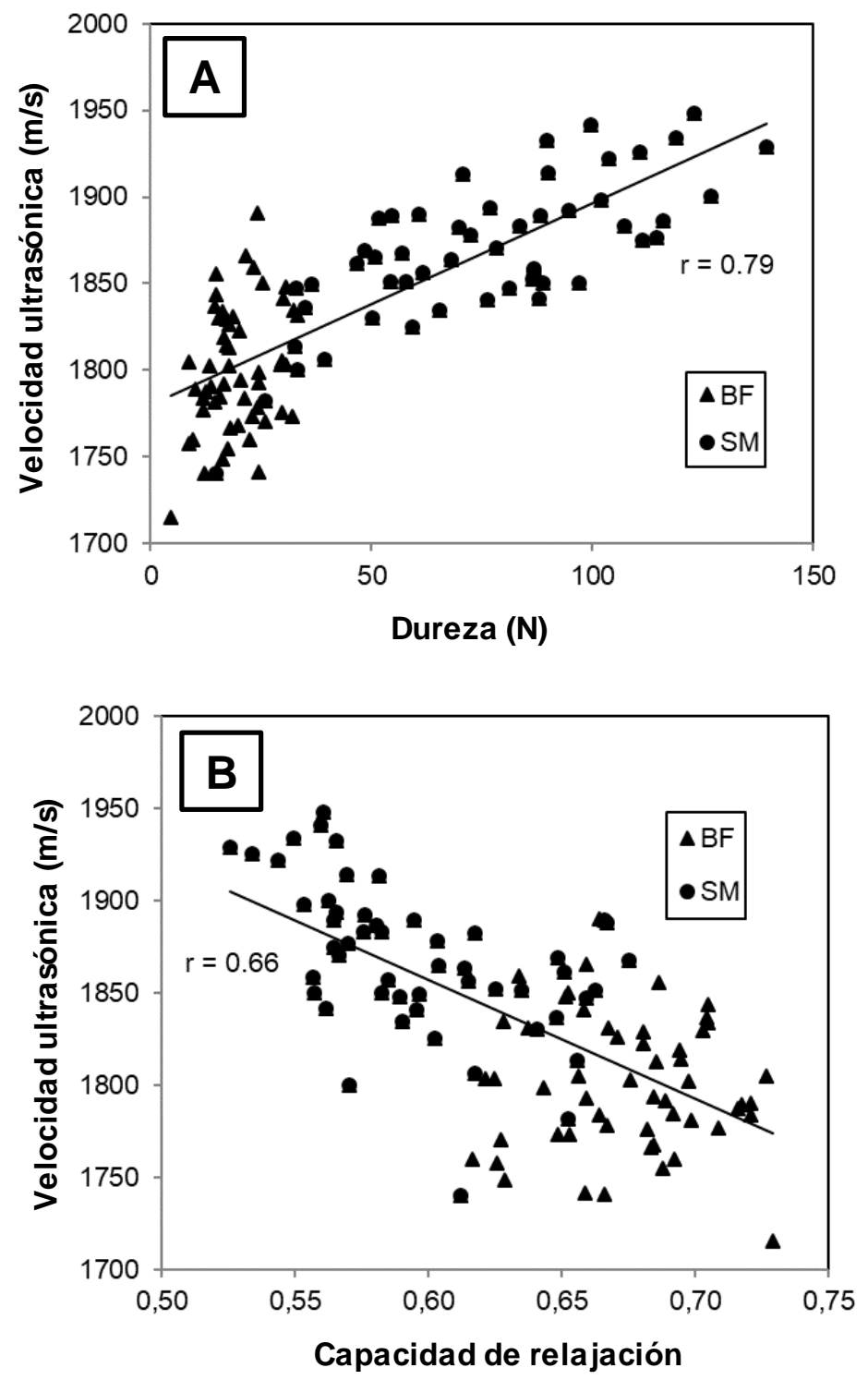

Figura 9. Relación entre la velocidad ultrasónica y la dureza (A) y la capacidad de relajación (B) para lonchas de jamón curado comercial ( $1 \mathrm{~cm}$ de espesor).

Por otro lado, en el producto loncheado, sí que fue posible la medida del coeficiente de atenuación, lo que permitió discriminar entre muestras con diferente intensidad en el defecto de pastosidad. La atenuación de los ultrasonidos aumentó con la intensidad del defecto, pasando de 43 (sin pastosidad) a $48 \mathrm{~Np} / \mathrm{m}$ (alta pastosidad) (Contreras et al., 2020) (Figura 10). Este 
incremento evidencia una mayor pérdida de energía en el tránsito de la onda ultrasónica, que podría explicarse por un comportamiento menos elástico y más viscoelástico, característico de las muestras pastosas. En este sentido, es necesario recalcar de nuevo que estas diferencias podrían incrementarse en jamones comerciales por el efecto de la sal y la humedad y su interacción con el defecto de pastosidad. Así, la medida de atenuación puede considerarse como una alternativa viable para discriminar entre muestras loncheadas con diferente intensidad en el defecto de pastosidad. Los resultados aquí mostrados deberían validarse en medidas en jamón entero ya que la tecnología es perfectamente aplicable en estas piezas.
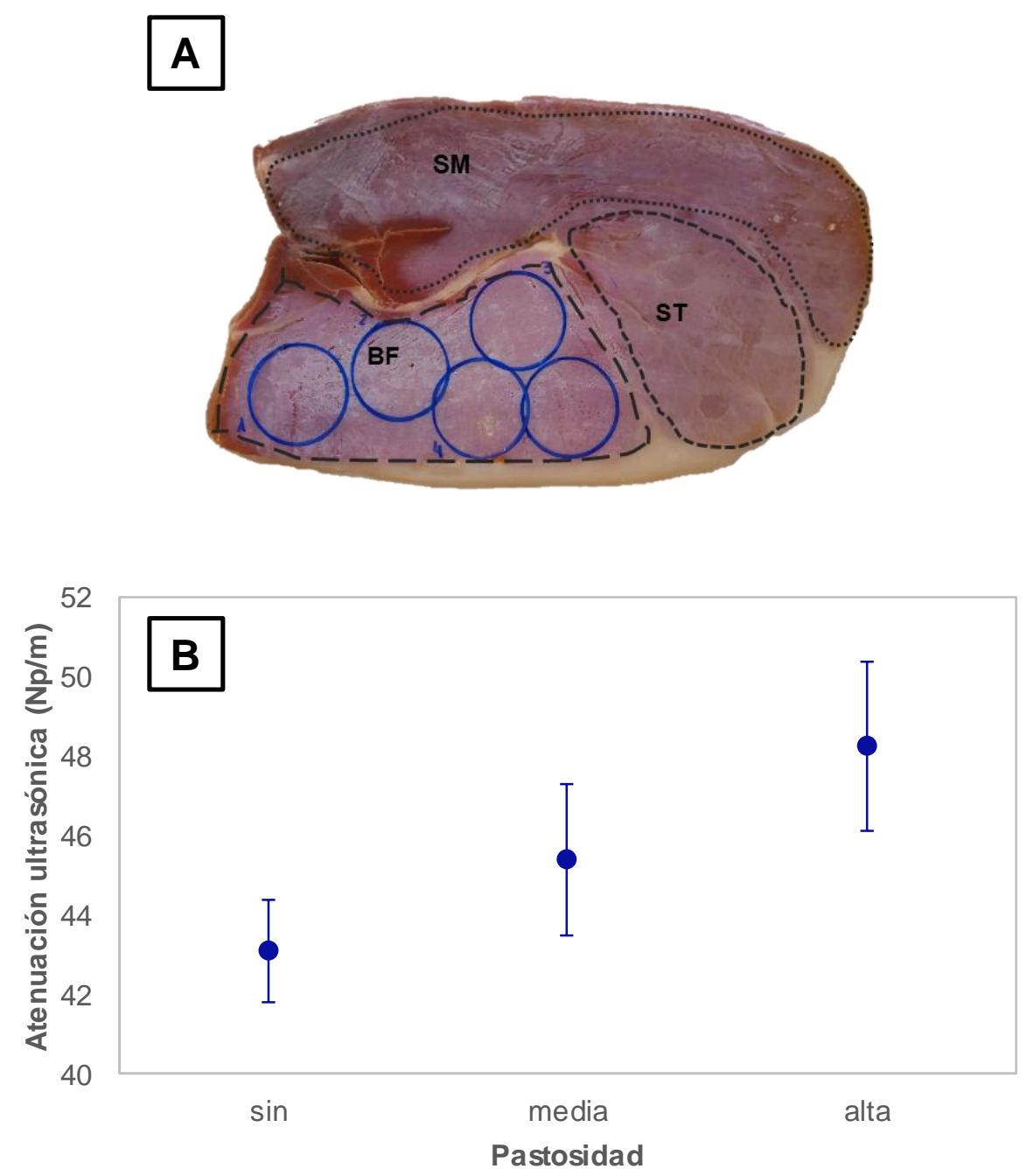

Figura 10. A. Detalle de la selección de los puntos de medida en el músculo Biceps femoris. B. Influencia del nivel de pastosidad sensorial (sin pastosidad<1, pastosidad media 1-2.5, alta pastosidad $>2.5)$ sobre la atenuación ultrasónica $(\mathrm{Np} / \mathrm{m})$. 


\section{Conclusiones}

El defecto de pastosidad en jamón curado presenta una elevada complejidad que dificulta su caracterización con las técnicas de análisis disponibles en la actualidad. Los resultados de caracterización no destructiva mediante ultrasonidos de baja intensidad obtenidos en el proyecto RTA2013-00030-C03 pusieron de manifiesto que la atenuación ultrasónica podría ser utilizada para discriminar entre muestras con diferente intensidad en el defecto de pastosidad. Las medidas ultrasónicas realizadas en el marco de este proyecto fueron por contacto directo, pero sería de esperar que la precisión de la medida de la atenuación mejorara al realizar las medidas ultrasónicas sin contacto (Figura 6C-6D) y por lo tanto, su capacidad para caracterizar el defecto de la pastosidad. Del mismo modo, las medidas sin contacto facilitarían la instalación de los sistemas ultrasónicos en las líneas industriales e, incrementarían la velocidad de medida de forma totalmente no invasiva. Finalmente, es necesario recalcar que la medida ultrasónica sin contacto es perfectamente viable tanto en producto loncheado como en piezas enteras de jamón curado.

\section{Referencias}

Arnau, J., Guerrero, L., \& Gou, P. (1997). Effects of temperature during the last month of ageing and of salting time on dry-cured ham aged for six months. Journal of the Science of Food and Agriculture, 74, 193-198.

Arnau, J., Guerrero, L., \& Sárraga, C. (1998). The effect of green ham pH and $\mathrm{NaCl}$ concentration on cathepsin activities and the sensory characteristics of dry-cured hams. Journal of the Science of Food and Agriculture, 77, 387-392.

Awad, T. S., Moharram, H. A., Shaltout, O. E., Asker, D., \& Youssef, M. M. (2012). Applications of ultrasound in analysis, processing and quality control of food: A review. Food Research International, 48, 410-427.

Bourne, M. C. (2002). Texture, viscosity and food. In Food Texture and Viscosity (2nd Editio, pp. 1-32). Academic Press.

Cho, B. K., \& Irudayaraj, J. M. K. (2003). A noncontact ultrasound approach for mechanical property determination of cheeses. Journal of Food Science, 68, 2243-2247.

Contreras, M., Benedito, J., Quiles, A., Lorenzo, J. M., Fulladosa, E., Gou, P., \& Garcia-Perez, J. V. (2020). Assessing the textural defect of pastiness in dry-cured pork ham using chemical, microstructural, textural and ultrasonic analyses. Journal of Food Engineering, 265, 109690.

Corona, E., Garcia-Perez, J. V., Gomez Alvarez-Arenas, T. E., Watson, N., Povey, M. J. W., \& 
Benedito, J. (2013). Advances in the ultrasound characterization of dry-cured meat products. Journal of Food Engineering, 119, 464-470.

de Prados, M., Fulladosa, E., Gou, P., Muñoz, I., Garcia-Perez, J. V., \& Benedito, J. (2015a). Non-destructive determination of fat content in green hams using ultrasound and X-rays. Meat Science, 104, 37-43.

de Prados, M., García-Pérez, J. V., \& Benedito, J. (2015b). Non-destructive salt content prediction in brined pork meat using ultrasound technology. Journal of Food Engineering, 154, 39-48. de Prados, M., Garcia-Perez, J. V., \& Benedito, J. (2016). Ultrasonic characterization and online monitoring of pork meat dry salting process. Food Control, 60, 646-655.

Fariñas, M. D., Ruiz, E., Diaz-Almanza, S., Gómez Álvarez-Arenas, T. E., Benedito, J., \& GarciaPerez, J. V. (2019). Airborne ultrasonic testing of pork burger patties. International Congress on Ultrasonics, 38, 032004.

Font-i-furnols, M., \& Guerrero, L. (2014). Consumer preference, behavior and perception about meat and meat products : An overview. Meat Science, 98, 361-371.

Fulladosa, E., Austrich, A., Muñoz, I., Guerrero, L., Benedito, J., Lorenzo, J. M., \& Gou, P. (2018). Texture characterization of dry-cured ham using multi energy X-ray analysis. Food Control, 89, 46-53.

Fulladosa, E., De Prados, M., García-Perez, J. V., Benedito, J., Muñoz, I., Arnau, J., \& Gou, P. (2015). X-ray absorptiometry and ultrasound technologies for non-destructive compositional analysis of dry-cured ham. Journal of Food Engineering, 155, 62-68.

Gan, T. H., Pallav, P., \& Hutchins, D. A. (2006). Non-contact ultrasonic quality measurements of food products. Journal of Food Engineering, 77, 239-247.

Garcia-Perez, J. V., de Prados, M., Martinez, G., Gomez Alvarez-Arenas, T. E., \& Benedito, J. (2019). Ultrasonic online monitoring of the ham salting process. Methods for signal analysis: Time of flight calculation. Journal of Food Engineering, 263, 87-95.

García-Rey, R. M., García-Garrido, J. A., Quiles-Zafra, R., Tapiador, J., \& Luque de Castro, M. D. (2004). Relationship between $\mathrm{pH}$ before salting and dry-cured ham quality. Meat Science, $67,625-632$.

García-Rey, R. M., García-Olmo, J., De Pedro, E., Quiles-Zafra, R., \& Luque De Castro, M. D. (2005). Prediction of texture and colour of dry-cured ham by visible and near infrared spectroscopy using a fiber optic probe. Meat Science, 70, 357-363.

Gómez Álvarez-Arenas T. E. (2004). Acoustic Impedance Matching of Piezoelectric Transducers to the Air. IEEE Trans Ultrason Ferroelectr Freq Control., 51, 624-633.

Gómez Álvarez-Arenas, T. E. (2013). Air-coupled piezoelectric transducers with active 
polypropylene foam matching layers. Sensors, 13, 5996-6013.

Guerrero, L., Gou, P., \& Arnau, J. (1999). The influence of meat pH on mechanical and sensory textural properties of dry-cured ham. Meat Science, 52, 267-273.

Koch, T., Lakshmanan, S., Brand, S., Wicke, M., Raum, K., \& Mörlein, D. (2011). Ultrasound velocity and attenuation of porcine soft tissues with respect to structure and composition: I. Muscle. Meat Science, 88, 51-58.

López-Pedrouso, M., Pérez-Santaescolástica, C., Franco, D., Fulladosa, E., Carballo, J., Zapata, C., \& Lorenzo, J. M. (2018). Comparative proteomic profiling of myofibrillar proteins in dry-cured ham with different proteolysis indices and adhesiveness. Food Chemistry, 244, $238-245$.

Martín, L., Córdoba, J. J., Antequera, T., Timón, M. L., \& Ventanas, J. (1998). Effects of salt and temperature on proteolysis during ripening of Iberian ham. Meat Science, 49, 145-153.

McClements, D. J. (1997). Ultrasonic characterization of foods and drinks: principles, methods, and applications. Critical Reviews in Food Science and Nutrition, 37, 1-46.

Morales, R., Guerrero, L., Aguiar, A. P. S., Guàrdia, M. D., \& Gou, P. (2013). Factors affecting dry-cured ham consumer acceptability. Meat Science, 95, 652-657.

Nowak, K. W., Markowski, M., \& Daszkiewicz, T. (2015). Ultrasonic determination of mechanical properties of meat products. Journal of Food Engineering, 147, 49-55.

Parolari, G. (1996). Review: Achievements, needs and perspectives in dry-cured ham technology: the example of Parma ham. Food Science and Technology International, 2, 69-78.

Parolari, G., Virgili, R., \& Schivazappa, C. (1994). Relationship between cathepsin B activity and compositional parameters in dry-cured hams of normal and defective texture. Meat Science, $38,117-122$.

Resano, H., Sanjuán, A. I., Cilla, I., Roncalés, P., \& Albisu, L. M. (2010). Sensory attributes that drive consumer acceptability of dry-cured ham and convergence with trained sensory data. Meat Science, 84, 344-351.

Ruiz-Ramírez, J., Arnau, J., Serra, X., \& Gou, P. (2005). Relationship between water content, $\mathrm{NaCl}$ content, $\mathrm{pH}$ and texture parameters in dry-cured muscles. Meat Science, 70, 579-587.

Ruiz-Ramírez, J., Arnau, J., Serra, X., \& Gou, P. (2006a). Effect of pH24, NaCl content and proteolysis index on the relationship between water content and texture parameters in biceps femoris and semimembranosus muscles in dry-cured ham. Meat Science, 72, 185-194.

Ruiz-Ramírez, J., Serra, X., Gou, P., \& Arnau, J. (2006b). Effect of proteolysis index on texture of dry-cured ham. Archivos Latinoamericanos de Producción Animal, 14, 62-64.

Saggin, R., \& Coupland, J. N. (2001). Non-contact ultrasonic measurements in food materials. - 276 - 
Food Research International, 34, 865-870. h

Sánchez-Torres, E. A., Fariñas, M. D., Gómez Álvarez-Arenas, T. E., Benedito, J., \& GarciaPerez, J. V. (2019). Non-invasive assessment of textural properties on sliced avocado by using air-coupled ultrasound. CIBIA XII Iberoamerican Congress of Food Engineering, 9497.

Schivazappa, C., Virgili, R., Simoncini, N., Tiso, S., Álvarez, J., \& Rodríguez, J. M. (2017). Application of the magnetic induction technique for the non-destructive assessment of salt gain after the salting process of Parma ham. Food Control, 80, 92-98.

Toldrá, F., \& Flores, M. (1998). The role of muscle proteases and lipases in flavor development during the processing of dry-cured ham. Critical Reviews in Food Science and Nutrition, $38,331-352$.

Villamiel, M., Garcia-Perez, J. V, Montilla, A., Cárcel, J. A., \& Benedito, J. (2017). Ultrasound in food processing Recent advances. Wiley Blackwell.

Watson, N., Hazlehurst, T., Povey, M., Vieira, J., Sundara, R., \& Sandoz, J. P. (2014). Can airborne ultrasound monitor bubble size in chocolate? Journal of Physics: Conference Series, 498, 1-13. 


